Рецензируемый и реферируемый научно-практический журнал Издается с 2008 г.

Выходит 6 раз в год + приложения

Решением президиума ВАК научнопрактический журнал «Вестник современной клинической медицины» включен в перечень российских

рецензируемых научных журналов, в которых публикуются основные научные результаты диссертаций на соискание научных степеней доктора и кандидата наук.

\section{УЧРЕДИТЕЛИ}

Общество с ограниченной ответственностью

«Многопрофильный медицинский центр

«Современная клиническая медицина»

при участии ГБОУ ВПО «Казанский

государственный медицинский университет» МЗ РФ

Журнал зарегистрирован Федеральной службой по надзору в сфере связи, информационных технологий и массовых коммуникаций (Роскомнадзор). Свидетельство ПИ № ФС 77-41624 от 11.08.2010.

Перерегистрирован 26.04.2013 г. Свидетельство ПИ № ФС 77-53842

Языки русский и английский

Подписной индекс журнала в каталоге «Пресса России» 41628

Каталог Казахстана 41628

Адрес редакции:

420043, Республика Татарстан,

г. Казань, ул. Вишневского, 57-83, тел. +7(843) 291-26-76, факс +7(843) 277-88-84,

тел/факс +7(843) 238-07-35,

e-mail: vskmjournal@gmail.com

Ученый секретарь журнала Даминова Мария Анатольевна, к.м.н., ассистент кафедры педиатрии и неонатологии ГБОУ ДПО КГМА Минздрава России (Казань), тел. +7-917-262-47-79,

e-mail: daminova-maria@yandex.ru

Отдел договоров и рекламы Руководитель Амирова Рената Наилевна, тел. +7-903-307-99-47, e-mail: renata1980@mail.ru

Компьютерное сопровождение и версия журнала в Интернете:

Шаймуратов Рустем Ильдарович, тел. +7-917-900-55-10,

e-mail: russtem@gmail.com

Доступен на сайтах:

www.vskmjournal.org,

www.kgmu.kcn.ru, www.elibrary.ru, www.cyberleninka.ru, www.eprints.ngmu.ru, twitter.com/vskmjournal Редколлегия журнала может не разделять точку зрения авторов на ту или иную проблему

(С) ООО ММЦ «Современная клиническая медицина», 2015 (c) Казанский ГМУ МЗ РФ, 2015

\section{ВЕСТНИК \\ СОВРЕМЕННОЙ КЛИНИЧЕСКОЙ МЕДИЦИНЫ}

\section{VESTNIK SOVREMENNOI KLINICHESKOI MEDICINY}

\section{НАУЧНО-ПРАКТИЧЕСКИЙ ЖУРНАЛ \\ Том 8, выпуск 32015 РЕДАКЦИОННАЯ КОЛЛЕГИЯ \\ Главный редактор}

Амиров Наиль Багаувич, д.м.н., проф. кафедры общей врачебной практики ГБОУ ВПО Казанский ГМУ Минздрава России, заслуженный деятель науки и образования, акад. РАЕ, заслуженный врач РТ, лауреат Гос. премии РТ в области науки и техники (Казань), e-mail: namirov@mail.ru

\section{Заместитель главного редактора}

Визель Александр Андреевич, д.м.н., проф., зав. кафедрой фтизиопульмонологии ГБОУ ВПО Казанский ГМУ Минздрава России, заслуженный врач РТ, лауреат Гос. премии РТ в области науки и техники (Казань), e-mail: lordara@inbox.ru

\section{Члены редколлегии}

Альбицкий Валерий Юрьевич, д.М.н., проф., заслуженный деятель науки РФ, лауреат премии Правительства РФ в области науки и техники, руководитель отдела социальной педиатрии РАН (Москва), e-mail: albicky@nczd.ru;

Амиров Наиль Хабибуллович, д.М.н., проф. кафедры гигиены, медицины труда ГБОУ ВПО Казанский ГМУ Минздрава России, академик РАН (Казань), e-mail: amirovn@yandex.ru;

Анисимов Андрей Юрьевич, д.м.н., проф. кафедры скорой медицинской помощи, медицины катастроф и мобилизационной подготовки специалистов здравоохранения ГБОУ ДПО КГМА Минздрава России, заслуженный врач РТ, гл. специалист-хирург МЗ РТ (Казань), e-mail: aanisimovbsmp@yandex.ru;

Галявич Альберт Сарварович, д.м.н., проф., зав. кафедрой факультетской терапии ГБОУ ВПО Казанский ГМУ Минздрава России, чл.-корр. АН РТ, вице-президент ВНОК, заслуженный врач РТ и РФ,

гл. специалист-кардиолог МЗ РТ (Казань), e-mail: agalyavich@mail.ru;

Зиганшин Айрат Усманович, д.м.Н., проф., зав. кафедрой

фармакологии фармацевтического факультета с курсами фармакогнозии и ботаники ГБОУ ВПО Казанский ГМУ Минздрава России, лауреат Гос. премии РТ в области науки и техники; заслуженный деятель науки РТ (Казань), e-mail: auziganshin@gmail.com;

Киясов Андрей Павлович, д.м.н., проф., директор Института фундаментальной медицины и биологии ФГАОУ ВПО КФУ, чл.-корр. АН РТ (Казань), e-mail: APKiyasov@ksu.ru;

Менделевич Владимир Давыдович, д.м.Н., проф., зав. кафедрой медицинской и общей психологии ГБОУ ВПО Казанский ГМУ Минздрава России (Казань), e-mail: mend@tbit.ru;

Никольский Евгений Евгеньевич, д.м.н., проф., зав. кафедрой медицинской и биологической физики с информатикой и медицинской аппаратурой ГБОУ ВПО Казанский ГМУ Минздрава России, академик РАН по отделению физиологии и фундаментальной медицины, зам. председателя КазНЦ РАН по научной работе (Казань); e-mail: eenik1947@mail.ru;

Созинов Алексей Станиславович, д.м.Н., проф., чл.-корр. АН РТ, ректор ГБОУ ВПО Казанский ГМУ Минздрава России, лауреат Гос. премии РТ в области науки и техники (Казань), e-mail: sozinov@kgmu.kcn.ru 


\section{Иностранные члены редколлегии}

Адольфо Балойра, врач-пульмонолог, проф. респираторной медицины госпиталя Понтеведра, координатор отделений генетики и легочной гипертензии Университета Виго, Испания, e-mail: adolfo.baloira.villar@sergas.es;

Жилберт Массард, проф., торакальный хирург, Страсбургский университет, отделение торакальной хирургии Страсбургского университета, Франция, e-mail: Gilbert.Massard@chru-strasbourg.fr;

Карл-Дитер Хеллер, проф., Клиника им. Герцогини Элизабет, зав. ортопедическим отделением, Брауншвейг, Германия, e-mail:KD.Heller@hen-bs.de;

Мажид Садих, проф. внутренних болезней Госпиталя Св. Марии Уотербери, шт. Коннектикут (клиника Йельского университета), Йель, США, e-mail: majid.sadigh@yale.edu;

Мелих Эльчин, проф., Университет Хачеттепе, отделение медицинского образования и информатики, Турция, e-mail: melcin@hacettepe.edu.tr;

тили Тансей, проф. истории современной медицины, Лондонский университет королевы Марии, Великобритания e-mail: t.tansey@gmul.ac.uk;

Феруз Гафурович Назыров, д.М.Н., проф., директор Республиканского специализированного центра хирургии им. акад. В. Вахидова, Ташкент, Узбекистан, e-mail: cs75@mail.ru;

Франтишек Выскочил, доктор наук, проф., член Ученого общества CZ, Физиологического общества, Кембридж, Лондон, Институт физиологии AVCR, факультет естественных наук Карлова университета, Прага, Чехия, e-mail: vyskocil@biomed.cas.cz

\section{Редакционный совет}

Анохин Владимир Алексеевич, д.м.н., проф., зав. кафедрой детских инфекций ГБОУ ВПО Казанский ГМУ Минздрава России, гл. детский специалист-инфекционист М3 РТ (Казань), e-mail: anokhin56@mail.ru;

Жестков Александр Викторович, д.м.Н., проф., зав. кафедрой микробиологии, иммунологии и аллергологии ГБОУ ВПО СамГМУ Минздрава России (Самара), e-mail: zhestkovav@yandex.ru; Жиляев Евгений Валерьевич, д.м.н., проф., гл. врач ЗАО «Юропиан медикал сентер», проф. кафедры ревматологии ГБОУ ДПО РМАПО Минздрава России (Москва), e-mail: zhilyayevev@mtu-net.ru;

Загидуллин Шамиль Зарифович, д.м.н., проф., зав. кафедрой пропедевтики внутренних болезней ГБОУ ВПО БГМУ Минздрава России (Уфа), e-mail: zshamil@inbox.ru; Зыятдинов Камиль Шагарович, д.м.н., проф., ректор ГБОУ ДПО КГМА Минздрава России, (Казань), e-mail: ksma@mi.ru;

Клюшкин Иван Владимирович, д.м.н., проф. кафедры общей хирургии ГБОУ ВПО Казанский ГМУ Минздрава России, лауреат Государственной премии РТ в области науки и техники, e-mail: hirurgivan@rambler.ru;

Маянская Светлана Дмитриевна, д.м.н., проф. кафедры госпитальной терапии с курсом эндокринологии ГБОУ ВПО Казанский ГМУ Минздрава России (Казань), e-mail: smayanskaya@mail.ru;

Рылова Наталья Викторовна, д.м.н., проф. кафедры госпитальной педиатрии с курсами поликлинической педиатрии и постдипломного образования

ГБОУ ВПО Казанский ГМУ Минздрава России, e-mail: rilovanv@mail.ru;

Сафина Асия Ильдусовна, д.м.н., проф., зав. кафедрой педиатрии и неонатологии ГБОУ ДПО КГМА Минздрава России, гл. специалист-педиатр МЗ РТ (Казань), e-mail: safina asia@mail.ru;

Сигитова Ольга Николаевна, д.М.Н., проф., зав. кафедрой ОВП ГБОУ ВПО Казанский ГМУ Минздрава России, заслуженный врач РТ и РФ, гл. специалист-нефролог МЗ РТ (Казань), e-mail: osigit@rambler.ru;

Синопальников Александр Игоревич, д.м.н., проф., зав. кафедрой пульмонологии ГБОУ ДПО РМАПО Минздрава России, e-mail: aisyn@list.ru, aisyn@ya.ru;

Фассахов Рустэм Салахович, д.м.н., проф., директор ФБУН «Казанский НИИ эпидемиологии и микробиологии» Роспотребнадзора, главный специалист аллерголог-иммунолог МЗ РТ и Приволжского ФО, e-mail: farrus@mail.ru

Рукописи не возвращаются, любое воспроизведение опубликованных материалов без письменного согласия редакции не допускается. Ответственность за содержание рекламы несет рекламодатель. Все рекламируемые в данном издании лекарственные препараты, изделия медицинского назначения и медицинское оборудование имеют соответствующие регистрационные удостоверения и сертификаты соответствия. 
Reviewed

scientific-practical journal

Published since 2008

Is issued 6 times a year + supplements

The «Bulletin of Contemporary Clinical Medicine» is recommended for publication of scientific results of $\mathrm{PhD}$ research for the degree of doctor

and candidate of sciences.

\section{CONSTITUTORS}

Multiprofile Medical Centre «Contemporary clinical medicine» Ltd with participation of SBEI HPE «Kazan State Medical University» of HM of RF

The journal is registered by the Federal Service for Supervision of Communication, Information Technology and Mass Media (Roskomnadzor). Certificate ПИ № ФС 77-41624 of 11.08.2010

Reregistered 26.04.2013

Certificate ПИ № ФС 77-53842

The languages: russian and english

Subscription index of the journal in the

«Pressa Rossii» catalogue is 41628

Catalogue of Kazakhstan is 41628

Editorial office and publishers address: Tatarstan Republic, 420043 Kazan, Vishnevsky str., 57-83. Contacts:

$+7(843) 291-26-76$ (tel.)

$+7(843) 277-88-84$ (fax),

$+7(843) 238-07-35$ (tel/fax),

e-mail: vskmjournal@gmail.com

Responsible Secretary of journal Maria A. Daminova, C.Med.Sci., assistant of professor of Department of pediatrics and neonatology of SBEI APE KSMA, tel. +7-917-262-47-79,

e-mail: daminova-maria@yandex.ru

\section{Marketing department} Contact person -

Chief Renata N. Amirova,

tel. +7-903-307-99-47,

e-mail: renata1980@mail.ru

\section{Computer support} and web version:

Rustem I. Shaymuratov,

tel. +7-917-900-55-10,

e-mail: russtem@gmail.com

Accessible on sites:

www.vskmjournal.org,

www.kgmu.kcn.ru, www.elibrary.ru, www.cyberleninka.ru, www.eprints.ngmu.ru, twitter.com/vskmjournal

Editorial board of the journal may disagree with authors' point of view on one or another issue

(C) Multiprofile Medical Centre

«Contemporary clinical medicine» Ltd, 2015 (c) Kazan SMU, 2015

\section{THE BULLETIN OF CONTEMPORARY CLINICAL MEDICINE}

\section{VESTNIK SOVREMENNOI KLINICHESKOI MEDICINY}

\section{SCIENTIFIC-PRACTICAL JOURNAL \\ Volume 8, issue 32015

\author{
EDITORIAL BOARD \\ Editor in chief
}

Nail B. Amirov, D.Med.Sci., Prof. of the Department of general medicine practice of SBEI HPE Kazan SMU of Russian Ministry of Health, Honored Science and Education Worker, Acad. of RANH,

TR Honored Doctor, State Honoree of TR in Science and Technics (Kazan), e-mail: namirov@mail.ru

\section{Deputy Editor in chief}

Alexander A.Vizel, D.Med.Sci., Prof., Head of the Department of phthisiopulmonology of SBEI HPE Kazan SMU

of Russian Ministry of Health, Honored Doctor of TR, State Honoree of TR in Science and Technics (Kazan), e-mail: lordara@inbox.ru

\section{Editorial Board}

Valery Yu. Albitsky, D.Med.Sci., Prof., Honored Science Worker of RF, State Honoree of RF Government in Science and Technics, head of Social Pediatrics Department of RAMS (Moscow), e-mail: albicky@nczd.ru;

Nail Kh. Amirov, D.Med.Sci., Prof. of the Department of occupational medicine of SBEI HPE Kazan SMU of Russian Ministry of Health, Acad. of RAS (Kazan), e-mail: amirovn@yandex.ru;

Andrey Yu. Anisimov, D.Med.Sci., Prof. of the Department of emergency care, disaster medicine and mobilization training of SBEI APE KSMA of Russian Ministry of Health (Kazan), e-mail: aanisimovbsmp@yandex.ru;

Albert S. Galyavich, D.Med.Sci., Prof., Head of the Department of faculty therapy of SBEI HPE Kazan SMU of Russian Ministry of Health, Corresponding Member of TR AS, Vice-president of RSSC,

Honored Doctor of TR and RF (Kazan), e-mail: agalyavich@mail.ru;

Airat U. Ziganshin, D.Med.Sci., Prof., Head of the Department of pharmacology of SBEI HPE Kazan SMU of Russian Ministry of Health, State Honoree of TR in Science and Technics (Kazan), e-mail: auziganshin@gmail.com;

Andrey P. Kiyasov, D.Med.Sci., Prof., Director of Fundamental Medicine and Biology Institute of KSU, Corresponding Member of TR AS (Kazan), e-mail: APKiyasov@ksu.ru;

Vladimir D. Mendelevich, D.Med.Sci., Prof., Head of the Department of medical and general psychology of SBEI HPE Kazan SMU of Russian Ministry of Health (Kazan), e-mail: mend@tbit.ru;

Evgenii E. Nikolsky, D.Med.Sci., Prof., Head of the Department of medical and biological physics with informatics and medical apparatus of SBEI HPE Kazan SMU of Russian Ministry of Health,

Acad. of RAS in Physiology and Fundamental Medicine Department, Vice-president of KazSC of RAS in research (Kazan), e-mail: eenik1947@mail.ru;

Alexey S. Sozinov, D.Med.Sci., Prof., Rector of SBEI HPE Kazan SMU

of Russian Ministry of Health, State Honoree of TR in Science and Technics (Kazan), e-mail: sozinov@kgmu.kcn.ru 


\section{Foreign Members of Editorial Board}

Adolfo Baloira, Prof. of respiratory medicine of Pontevedra Hospital, coordinator of genetic and pulmonary hypertension department of Vigo University, lung specialist, Spain,

e-mail: adolfo.baliora.villar@sergas.es;

Gilbert Massard, Prof., M.D. Centre Hospitalier, Department of Thoracic Surgery Place de l'Hopital BP 426 Strasbourg 67091, France, e-mail: Gilbert.Massard@chru-strasbourg.fr;

Karl-Dieter Heller, Prof., Dr. med., Chief of Staff Herzogin Elisabeth Hospital, Orthopedic Hospital, Braunschweig, Germany, e-mail:KD.Heller@hen-bs.de;

Majid Sadigh, Prof. internal diseases unit of St. Mary Waterbury Hospital, Connecticut (Yale University Clinic), Yale, USA, e-mail: majid.sadigh@yale.edu;

Melih Elcin, Assoc. Prof., M.D., MSc. Head, Department of Medical Education \& Informatics, Turkey, e-mail: melcin@hacettepe.edu.tr;

Tilly Tansey, Prof. of the History of Modern Medical Sciences School of History, Queen Mary University of London, Mile End Road, London E1 4NS, UK, e-mail: t.tansey@gmul.ac.uk;

Feruz G. Nazyrov, D. Med. Sci., Prof., Director of Specialized center of Surgery n.a. academician V.Vahidov, Tashkent, Uzbekistan, e-mail: cs75@mail.ru;

Frantisek Vyskocil, Doc.Sci., Prof., CZ Physiologic fellow, Cambridge, London, Physiologic Institute AVCR, Natural Science Faculty of Karl University, Prague, the Czech Republic, e-mail: vyskocil@biomed.cas.cz

\section{Editorial council}

Vladimir A. Anokhin, D.Med.Sci., Prof., Head of Department of children's infection of SBEI HPE KSMU (Kazan), e-mail: anokhin56@mail.ru;

Alexander V. Zhestkov, D.Med.Sci., Prof., Head of the Department of microbiology, immunology and allergology of SBEI HPE «SamaraSMU» of RF HM (Samara), e-mail: zhestkovav@yandex.ru;

Evgenii V. Zhilyayev, D.Med.Sci., Prof. of the Department of Rheumatology of SBEI APE RMAPE, Head physician of CJSC «European Medical Center» (Moscow), e-mail: zhilyayevev@mtu-net.ru;

Shamil Z. Zagidullin, D.Med.Sci., Prof., Head of the Department of propedeutics of Inner Diseases of SBEI HPE BSMU (Ufa), e-mail: zshamil@inbox.ru;

Kamil Sh. Ziyatdinov, D.Med.Sci., Prof., Rector of SBEI APE KSMA (Kazan), e-mail: ksma@mi.ru; Ivan V. Klushkin, D. Med. Sci., Prof. of General Surgery Department

of SBEI HPE «Kazan State Medical University» of Russian Ministry of Health, Kazan, Russia, State Laureate of Tatarstan Republic in Science and Technics, e-mail: hirurgivan@rambler.ru;

Svetlana D. Mayanskaya, D.Med.Sci., Prof. of the Department of hospital therapy of SBEI HPE KSMU (Kazan), e-mail: smayanskaya@mail.ru;

Natalia V. Rilova, D. Med. Sci., Prof. of Hospital Pediatrics Department with Polyclinic Pediatry and Postgraduate Education of SBEI HPE «Kazan State Medical University» of Russian Ministry of Health, Kazan, Russia, e-mail: rilovanv@mail.ru;

Asiaya I. Safina, D.Med.Sci., Prof., Head of the Department of pediatry of SBEI APE KSMA (Kazan), e-mail: safina_asia@mail.ru;

Olga N. Sigitova, D.Med.Sci., Prof., Head of the Department of general practice of SBEI HPE KSMU, Honored Doctor of TR and RF (Kazan), e-mail: osigit@rambler.ru;

Alexander I. Sinopalnikov, D. Med. Sci., Prof., Head of Pulmonology Department of SBEI APE «Russian Medical Academy of Postgraduate Education», e-mail: aisyn@list.ru, aisyn@ya.ru;

Rustem S. Fassakhov, D. Med. Sci., Prof., Director of Kazan Scientific and Research institute of epidemiology and microbiology, Kazan, Russia, main specialist out-of-stuff in Allergology and Immunology in Tatarstan Republic and Volga Federal District, e-mail: farrus@mail.ru

The manuscripts are not given back, any copy without editorial board's written permission is not allowed. Advertiser is responsible for publicity's content. All medicines, medical products and medical equipment, mentioned in publication, have registration certificates. 


\section{ОРИГИНАЛЬНЫЕ ИССЛЕДОВАНИЯ}

Саркоидоз органов дыхания у военнослужащих. Д.Н. Антипушина, А.А. Зайцев ..................... 7

Эффективность дабигатрана этексилата в лечении варфарин-индуцированного тромбоза после артропластики тазобедренного сустава. Л.В. Борисова, С.Н. Дидиченко, А.В. Орлова .. 11

Мониторинг качества жизни населения с помощью опросника SF-36 как опережающий индикатор прогнозирования эпидемиологической обстановки по туберкулезу. А.Н. Данилов

Результаты тотального разобщения гастроэзофагеального коллектора у больных с синдромом портальной гипертензии. Ф.Г. Назыров, А. В. Девятов, А.Х. Бабаджанов, Ж.Д. Жамилов

Опыт ортопедического лечения больных с челюстно-лицевой патологией. А.И. Рафф .25

Характер ассоциаций полиморфизма гена аполипопротеина В-100 с нарушениями липидного обмена у больных желчнокаменной болезнью. А.А. Сагдатова, А.Х. Нургалиева, Э.К. Хуснутдинова, Ш.З. Загидуллин .

Депрессия в неврологической практике (на примере болевых синдромов и инсульта). Д.P. Teрегулова, М.А. Кутлубаев, Л.Р. Ахмадеева .....32

Показатели липидного обмена пациентов с ишемической болезнью сердца и коморбидной патологией в зависимости от степени стеноза ствола левой коронарной артерии. Г.3. Халимова, А.С. Галявич, М.В. Панасюк..... 36

Результаты применения манитно-инфракрасной лазерной терапии в комплексном лечении больных с впервые выявленным деструктивным туберкулезом легких. А.Л. Ханин,

Г.В. Пильник, Г.Л. Никотина

\section{ОРГАНИЗАЦИЯ ЗДРАВООХРАНЕНИЯ}

Состояние инвалидности населения города Казани за 1995-2011 годы. Н.Н. Шамсияров, А.Н. Галиуллин 45

\section{В ПОМОЩЬ ПРАКТИЧЕСКОМУ ВРАЧУ}

Новый инструмент и способ, облегчающий завязывание хирургических узлов при лапароскопических гинекологических операциях. О.В. Галимов, Э.Ю. Дмитриева, В.О. Ханов, О.А. Филиппова.

Комплексный подход в лечении детей с врожденными расщелинами верхней губы и нёба в Республике Татарстан. П.В. Токарев,

А.В. Шулаев, Л.В. Плаксина.

\section{ОБзоры}

Закрытая травма сердца на догоспитальном этапе. А.И. Абдрахманова, Н.Б. Амиров, Н.А. Цибулькин .

Кардиопротективный эффект ишемического кондиционирования. А.З. Шарафеев,

В.А. Баязитова, А.Р. Исхакова

ПИСЬМО В РЕДАКЦИЮ

Электронные сигареты - «способ курения» или средство отказа от курения? Комментарий к статье В.Д. Менделевича. П.К. Яблонский,

O.A. Суховская

\section{КОГДА ВЕРСТАЛСЯ НОМЕР}

Публикационная этика и редакционная политика журнала «Вестник современной клинической медицины». Н.Б. Амиров,

А.А. Визель, М.А. Даминова, Р.Н. Амирова, Р.И. Шаймуратов

Правила оформления статей и тезисов для авторов в журнал и приложения «Вестник современной клинической медицины» ISSN 2071-0240 (Print), issn 2079-553x (on line) 


\section{ORIGINAL ARTICLES}

Respiratory sarcoidosis in military servants.

D.N. Antipushina, A.A. Zaytsev.

Efficiency of dabigatran etexilatein treatment of warfarin-induced thrombosis after hip arthroplasty. L.V. Borisova, S. N. Didichenko, A.V. Orlova........ 12

Monitoring the quality of life using a questionnaire SF-36 as a leading indicator prediction epidemiological situation tuberculosis. A.N. Danilov

Result of total dissociation of gastroesophageal collector in patients with portal hypertension. F.G. Nazyrov, A.V. Devyatov, A.Kh. Babadzhanov, Zh.D. Zhamilov...

Practice orthopedic treatment of patients with maxillofacial pathology. A.I. Raff

Nature association of polymorphism gene apolipoprotein $B-100$ with lipid metabolism in patients with cholelithiasis. A.A. Sagdatova, A.Kh. Nurgalieva, E.K. Khusnutdinova, Sh.Z. Zagidullin .....29

Depression in neurological practice (in cases of pain syndromes and stroke). D.R.Teregulova, M.A.Kutlubaev, L.R. Akhmadeeva

Lipid metabolism in patients with coronary artery disease and comorbidities depending on stenosis of the left main coronary artery. G.Z. Khalimova, A.S. Galyavich, M.V. Panasyuk.

Results of using magnetic-infrared-laser therapy in complex treatment of patients with new-onset destructive pulmonary tuberculosis. A.L. Khanin, G.V. Pilnik, G.L. Nicotina 40

\section{ORGANIZATION OF HEALTHCARE}

State disability population city of Kazan 1995-2011 yy. N.N. Shamsiyarov, A.N. Galiullin

\section{HELP FOR PRACTITIONER}

New tool and method of tying surgical units in laparoscopic gynecological surgery. O.V. Galimov, E.Yu. Dmitrieva, V.O. Khanov, O.A. Filippova....

The complex approach in treatment of children with congenital labium and palate clefts in Tatarstan Republic practice. P.V. Tokarev, A.V. Shulaev, L.V. Plaksina

\section{REVIEWS}

Closed heart injury on the prehospital. A.I. Abdrakhmanova, N.B. Amirov, N.A. Tsibulkin ................. 57 Cardioprotective effect of ischemic conditioning.

A.Z. Sharafeev, V.A. Bayazitova, A.R. Iskhakova ...65 CORRESPONDENCE

Electronic cigarettes - «way of smoking» or quit smoking devices? Commentary article on V.D. Mendelevich. P.K. Yablonsky, O.A. Sukhovskaya ........72

\section{DURING THE IMPOSING OF THE NUMBER}

Publication Ethics and Editorial Policy of journal «The Bulletin of Contemporary Clinical Medicine». N.B. Amirov, A.A.Vizel, M.A. Daminova, R.N. Amirova, R.I. Shaymuratov

The bulletin of contemporary clinical medicine ISSN 2071-0240 (Print), issn 2079-553x (on line) 


\section{САРКОИДОЗ ОРГАНОВ ДЫХАНИЯ У ВОЕННОСЛУЖАЩИХ}

ДИАНА НИКОЛАЕВНА АНТИПУШИНА, старший ординатор пульмонологического отделения ГВКГ им. Н.Н. Бурденко, Москва, Россия, тел. 8-499-263-53-20, e-mail: dndoc@bk.ru

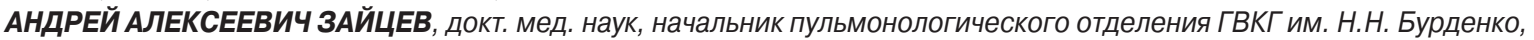
Москва, Россия, тел. 8-499-263-10-47, e-mail: a-zaicev@yandex.ru

Реферат. Цель исследования - изучение клинических особенностей, качества жизни и определение фракторов риска рецидивирующего течения саркоидоза у военнослужащих. Материал и методы. Обследовано 124 больных, средний возраст составил $(31,8 \pm 9,9)$ года. Изучены клинические, рентгенологические и лабораторные данные, проведен анализ качества жизни с помощью опросника SHQ, корреляционный анализ. Результаты и их обсуждение. Установлено, что у военнослужащих в 85,5\% диагностируется I и II стадии саркоидоза органов дыхания, преобладает бессимптомное течение заболевания (72\%). В целях морфологической верификации процесса наиболее часто выполнялась медиастиноскопия с биопсией внутригрудного лимфоузла (36,3\%), доля травматичных хирургических операций составила 6,2\%. Качество жизни военнослужащих с саркоидозом снижено по шкалам ежедневного функционирования, физической и эмоциональной активности $(56,7,80$ и $70 \%$ соответственно). Установлены фракторы, ассоциированные с рецидивирующим течением саркоидоза: возраст более 35 лет ( $p=0,039$, ОШ - 5,03); наличие клинических проявлений $(p=0,011$, ОШ - 3,47) (кашель, слабость, одышка); фрорсированная жизненная емкость легких (ФЖЕЛ) менее $85 \%$ от должных величин ( $p=0,029$, ОШ $4,23)$; терапия системными глюкокортикостероидами (ГКС) в анамнезе $(p=0,004$, ОШ - 11,43). Разработана шкала прогноза с практической ценностью $(82,4 \%)$, чувствительностью $(58,8 \%)$ и специфичностью $(88,2) \%$. Заключение. Полученные данные свидетельствуют о необходимости внедрения в практику ведения больных саркоидозом из числа военнослужащих единого алгоритма, включающего широкое использование малотравматичных методов морфологической верификации, взвешенного подхода к назначению системных стероидов. Несмотря на преобладание бессимптомных форм заболевания, качество жизни больных саркоидозом военнослужащих снижено. Факторами риска рецидивирующего течения являются: возраст более 35 лет, наличие клинических проявлений, ФЖЕЛ менее 85\%, лечение ГКС в анамнезе. Разработана шкала прогноза рецидивирующего течения саркоидоза у молодых пациентов, обладающая высокой прогностической ценностью.

Ключевые слова: саркоидоз, военнослужащие, факторы риска рецидивирующего течения, шкала прогноза развития рецидивов саркоидоза.

\section{RESPIRATORY SARCOIDOSIS IN MILITARY SERVANTS}

DIANA N. ANTIPUSHINA, Senior registrar of the Department of pulmonary of the Main Military Clinical Hospital of named after acad. N.N. Burdenko, Moscow, Russia, tel. 8-499-263-53-20, e-mail: dndoc@bk.ru ANDREY A. ZAYTSEV, Doctor of Medical Sciece, Chief of the Department of pulmonary of the Main Military Clinical Hospital of named after acad. N.N. Burdenko, Moscow, Russia, tel. 8-499-263-10-47, e-mail: a-zaicev@yandex.ru

Abstract. Objective. To study the clinical features and quality of life and to determine risk factors for the recurrent sarcoidosis among the military servants. Material and methods. The study involved 124 patients, mean age $(31,8 \pm 9,9)$ years. The clinical, radiological and laboratory data have been examined, the quality of life has been analysed using a SHQ questionnaire, the correlation analysis was performed. Results and discussion. It was found that $85,5 \%$ of military personnel had respiratory sarcoidosis of stages I and II, asymptomatic disease course prevailed $(72 \%$ of cases). Morphological verification of the sarcoidosis was most frequently performed by mediastinoscopy with biopsy of intrathoracic lymph nodes $(36,3 \%)$; the percentage of traumatic surgery was $6,2 \%$. The quality of life of military personnel with sarcoidosis was reduced according to the scales of daily, physical and emotional functioning up to $56,7,80$ to $70 \%$ of cases respectively. The factors associated with recurrent sarcoidosis were: age $>35$ years $(p=0,039$, OR $5,03)$; the presence of clinical manifestations $(p=0,011$, OR $-3,47)$ (cough, weakness, shortness of breath); FVC $<$ $85 \%$ of predicted values $(p=0,029$, OR $-4,23)$; systemic corticosteroids in past history $(p=0,004$, OR $-11,43)$. We designed predictive scale, the practical value of which amounted to $82,4 \%$, sensitivity $58,8 \%$ and specificity of $88,2 \%$. Conclusion. The findings suggests the need to implement a common algorithm for the management of military personnel sarcoidosis, including the widespread use of minimally invasive methods of morphological verification, the balanced approach to the prescription of systemic steroids. Despite the prevalence of asymptomatic forms of the disease, the quality of life of patients with sarcoidosis is decreased. The risk factors for relapse are: age $>35$ years, the presence of clinical manifestations, FVC $<85 \%$, SCS treatment history. There have been designed predictive scale for recurrent course of sarcoidosis in young patients which has a high predictive value.

Key words: sarcoidosis, the military, risk factors of the recurrent course, the scale of the forecast the relapse of sarcoidosis. 
$B$ ведение. Несмотря на значительные достижения современной медицины, в диагностике и лечении саркоидоза органов дыхания (СОД) по-прежнему остается ряд пробелов, в том числе связанных с особенностями течения саркоидоза в разных профессиональных и возрастных группах. Стоит заметить, что интерес к проблеме саркоидоза в настоящее время находится на этапе все возрастающего роста. Известно, что распространенность данного заболевания в России варьирует от 22 до 47 на 100 тыс. взрослого населения [1-4]. Чаще болеют взрослые в возрасте до 40 лет, пик заболеваемости приходится на 20-30 лет [4]. Учитывая данный факт, стоит предположить, что проблема саркоидоза является актуальной и для военно-медицинской службы. Этот тезис подтверждает ряд сообщений из США, согласно которым регистрируется высокая заболеваемость саркоидозом среди военных моряков, проходящих службу на авианосцах [5]. Данные о распространенности саркоидоза в системе российского военного здравоохранения носят ориентировочный характер, при этом известно, что в последние годы отмечается неуклонный рост количества пациентов из числа военнослужащих, которые получают лечение в пульмонологических отделениях стационаров по поводу саркоидоза органов дыхания [6]. Следует признать, что в настоящее время отсутствуют данные о наиболее распространенных клинических формах саркоидоза у военнослужащих, нет обобщенных результатов фармакоэпидемиологических исследований о тактике лечения больных саркоидозом в военно-лечебных организациях (ВЛО) и не разработаны подходы, позволяющие прогнозировать течение заболевания у молодых людей из числа военнослужащих. Стоит отдельно отметить, что именно рецидивирующий характер заболевания, обусловливающий необходимость пожизненного наблюдения, заставляет искать новые способы оценки прогноза, определяющие дальнейшую лечебную тактику и своевременную диагностику рецидивов саркоидоза. При этом исследований, посвященных поиску прогностических критериев, позволяющих простыми, доступными методами оценить вероятность рецидивирующего течения саркоидоза, у военнослужащих не проводилось. Таким образом, является актуальным изучение клинических, фармакоэпидемиологических и прогностических аспектов саркоидоза органов дыхания у военнослужащих.

Цель исследования - изучение диагностической и лечебной тактики ведения больных саркоидозом в военно-лечебных учреждениях, изучение качества жизни и определение факторов риска рецидивирующего течения заболевания у пациентов с саркоидозом из числа военнослужащих.

Материал и методы. В исследование включено 124 военнослужащих с саркоидозом органов дыхания, средний возраст которых составил $(31,8 \pm 9,9)$ года, период наблюдения - $(26,6 \pm 7,8)$ мес. Дизайн исследования состоял из следующих этапов:

1) оценка жалоб, анамнеза, анализ рентгенологических, клинических проявлений СОД у военнослужащих;
2) комплексное обследование с обязательной морфологической верификацией процесса (если это не было выполнено на предшествующем этапе);

3) оценка лабораторных показателей, уровня кальция крови и мочи, показателей спирометрии, диффузионной способности легких;

4) анализ методов морфологической верификации и лечебной тактики на предшествующих этапах лечения;

5) анализ наличия маркеров Chlamydophila pneumoniae u Mycoplasma pnuemoniae - инфекции у военнослужащих с СОД;

6) оценка качества жизни военнослужащих с СОД по вопроснику Sarcoidosis Health Questionnaire (SHQ) с повторным анкетированием через 1 мес;

7) анализ результатов динамического наблюдения больных, определение факторов риска рецидивирующего течения саркоидоза;

8) создание шкалы прогноза рецидивирующего течения саркоидоза у военнослужащих.

Статистические расчеты включали описательную статистику, корреляционный анализ, анализ ассоциаций, ROC-анализ с определением площади под кривой (AUC), анализ прогностической ценности, чувствительности и специфичности шкалы прогноза заболевания.

Результаты и их обсуждение. Среди 124 обследованных больных СОД преобладали мужчины (96\%). Как правило, признаки саркоидоза выявлялись при плановой рентгенографии во время ежегодного диспансерного обследования. Рентгенологическая картина в 85\% случаев (106 пациентов) соответствовала СОД II стадии [поражение легких и внутригрудных лимфатических узлов (ВГЛУ)], СОД I стадии (поражение ВГЛУ) диагностировался у 10\% (13 больных); а СОД III стадии (патология легочной паренхимы без лимфраденопатии ВГЛУ), генерализованный саркоидоз и комбинация СОД с поражением сердца представляли единичные случаи и встречались редко - в 1, 2 и $2 \%$ случаев соответственно.

У преобладающего числа пациентов (72\%) наблюдалось бессимптомное течение заболевания. Наличие клинических проявлений СОД отмечено у $28 \%$ (35 больных). Чаще всего наблюдались кашель - у 13 пациентов (10,5\%), немотивированная общая слабость - у 12 больных (9,7\%), одышка - у 8 пациентов (6,5\%), кожные проявления встречались в 4 случаях, гипертермия отмечалась у 6 пациентов. Острое начало в виде синдрома Лефгрена диагностировано у 2 пациентов $(2,4 \%)$, синдром Хеерфордта - у 1 больного (1,2\%). Внелегочные проявления саркоидоза отмечены у 12 пациентов (9,6\%): у 4 больных - поражение кожи в рамках саркоидоза, у 3 - поражение голеностопных суставов, у 2 пациентов наблюдалось поражение сердца, в одном случае диагностировано поражение центральной нервной системы (ЦНС) - саркоидоз головного мозга с частыми эпиприпадками и рассеянной органической симптоматикой, также однократно отмечалось вовлечение в процесс селезенки и околоушных слюнных желез. Поражение сердца при саркоидозе сопровождались регистрацией на 
электрокардиограмме преходящей АВ-блокады II и III степени с приступами Морганьи - Эдамса Стокса, что в обоих случаях потребовало имплантации электрокардиостимулятора.

Лабораторные показатели периферической крови и кальциевого обмена в подавляющем числе случаев находились в пределах нормальных значений и не корреспондировали с активностью процесса. Изучение показателей функции внешнего дыхания у военнослужащих с СОД в 92\% случаев каких-либо отклонений от возрастной нормы не выявило, в 7,2\% были диагностированы обструктивные нарушения, у одного больного $(0,8 \%)$ наблюдался смешанный тип нарушений.

При исследовании диагностической тактики ведения больных саркоидозом в ВЛО установлено, что для получения биопсийного материала с целью морфологической диагностики саркоидоза наиболее часто использовались медиастиноскопия с биопсией ВГЛУ (36,3\%), видеоассистированная торакоскопия с биопсией ВГЛУ либо легкого (20,2\%), малоинвазивные эндоскопические методы - эндоскопическая трансбронхиальная биопсия ВГЛУ либо легкого $(32,3 \%)$ (рис. 1). Отдельно стоит отметить, что в структуре методов морфологической верификации процесса сохраняются и травматичные хирургические операции (торакотомия с резекцией доли легкого) $-6,2 \%$.

По результатам фрармакоэпидемиологического исследования в 41,9\% случаев (52 пациента) на ранних этапах лечения были назначены системные ГКС. Учитывая указанные ранее особенности течения СОД у военнослужащих, бессимптомное течение заболевания у большинства больных (72\%), рентгенологические признаки саркоидоза I и II степени (96,7\%), отсутствие значимых нарушений вентиляционной фрункции легких (92\%), стало очевидным, что первоначальная терапия в подобных случаях, согласно современным рекомендациям [1], не должна включать применение системных глюкокортикостероидов (ГКС).
С целью оценки качества жизни (КЖ) военнослужащих с саркоидозом выполнен анализ анкет опросника SHQ, заполненных 30 пациентами дважды с интервалом в 1 мес (при поступлении в стационар и через 1 мес наблюдения). В ходе исследования оценивались ежедневное функционирование (13 вопросов), фризическое функционирование (6 вопросов), эмоциональное функционирование (10 вопросов) и общая сумма баллов SHQ.

По шкале ежедневной активности снижение КЖ при первичном исследовании отмечалось у 17 больных (56,7\%), а при повторном - у 20 (66,7\%). Ухудшение КЖ обусловлено утомляемостью, нарушениями сна, ухудшением социальных взаимоотношений в связи с заболеванием, снижением самооценки. По шкале фризической активности при первом и втором тестировании ухудшение КЖ отмечено у 24 военнослужащих (80\%). Основные симптомы, влияющие на снижение физической активности: головные боли, дыхательный дискомфорт, боли в суставах, одышка, кашель. По шкале эмоциональной активности показатель КЖ был снижен у 21 больного СОД (70\%) в первом тестировании и у 18 (60\%) - во втором. Пациенты отмечали перепады настроения, депрессию, беспокойство из-за чувства боли или дыхательного дискомфорта, снижение концентрации внимания, выражали сомнение по поводу хорошего самочувствия в будущем. Суммарно по результатам интервьюирования с помощью SHQ при повторном тестировании было отмечено улучшение КЖ по общей сумме баллов за счет улучшения показателей по шкалам «ежедневное функционирование» и «физическое функционирование» (рис. 2).

Статистически значимых межгрупповых различий по данным показателям у пациентов с рецидивами и стабильным течением СОД по критерию МаннаУитни не выявлено. Однако даже у пациентов, не предъявляющих жалоб при первичном осмотре, по результатам теста выявлено снижение КЖ по всем трем шкалам. Также обращает на себя внимание

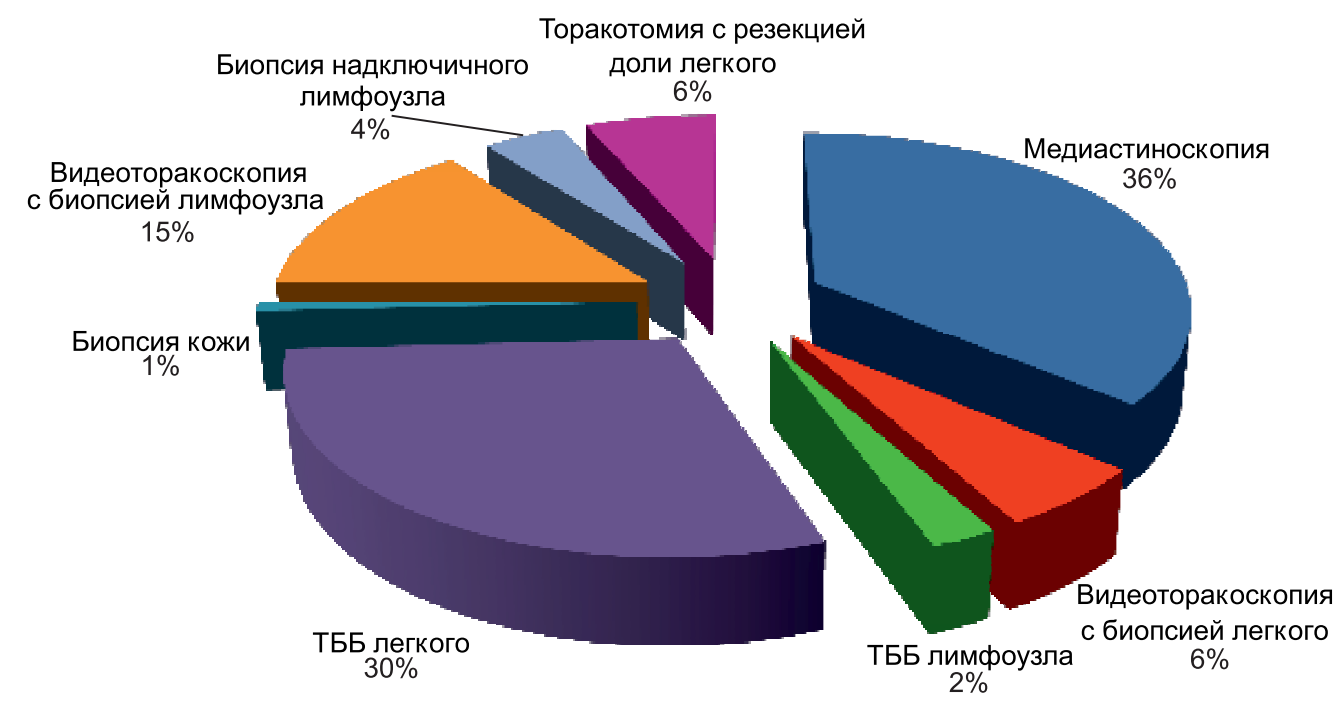

Рис. 1. Методы получения биопсийного материала для морфологической верификации саркоидоза, применяемые в военно-лечебных организациях 


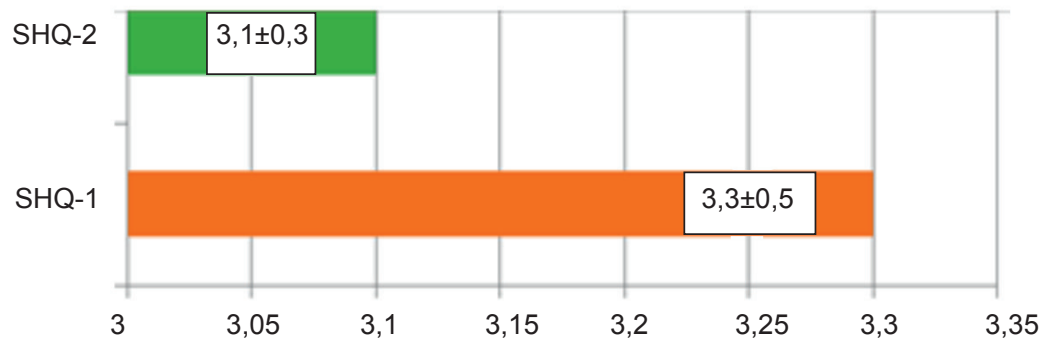

Рис. 2. Результаты тестирования больных саркоидозом с использованием опросника SHQ: SHQ-1 - средняя сумма баллов у больных саркоидозом по опроснику SHQ при первичном обследовании; $\mathrm{SHQ}-2$ - средняя сумма баллов по опроснику SHQ через месяц наблюдения

наличие умеренной корреляционной связи $(p<0,05)$ результатов теста с возрастом (т.е. чем старше больной, тем хуже КЖ).

Анализ фракторов риска рецидивирующего течения саркоидоза проводился у 85 длительно наблюдаемых (2 года и более) нами пациентов, которые в ходе исследования были разделены на две группы: 1-я группа - стабильное течение СОД; 2-я группа - рецидивирующее течение СОД. В 1-ю группу были включены 68 пациентов, средний возраст которых составил $(35 \pm 9,9)$ года. Во 2-ю группу - 17 больных, средний возраст $(40,8 \pm 9,86)$ года.

Путем корреляционного анализа и подсчета отношения шансов с 95\% ДИ были установлены фракторы, достоверно ассоциированные с рецидивирующим течением саркоидоза: возраст более 35 лет $(p=0,039)$, наличие клинических проявлений саркоидоза ( $p=0,011)$, кашель $(p=0,019)$, слабость $(p=0,012)$, одышка $(p=0,04)$, ФЖЕЛ менее $85 \%$ от должного $(p=0,029)$; терапия системными ГКС в анамнезе $(p=0,004)$. Для возраста был определен пороговый уровень более 35 лет, а для ФЖЕЛ менее $85 \%$, так как при таких значениях данных критериев риска 1-я и 2-я группы значимо различались $(p<0,05)$.

На основании указанных фракторов составлена шкала прогноза рецидивирующего течения СОД [шкала КФТ-35, где К - клинические проявления; Ф - ФЖЕЛ, Т - терапия системными стероидами в анамнезе; 35 - возраст (пороговое значение)] с суммарным баллом 4, включающая вышеозначенные четыре критерия риска (таблица). Оценка прогностической ценности (дискриминационной способности) шкалы проведена методом ROCанализа. Полученные значения AUC (площадь под ROC-кривой) оказались достаточно высокими (AUC - 0,788). Чувствительность модели составила $58,8 \%$, специфичность - 88,2\%, прогностическая ценность теста $-82,4 \%$.

Методом отношения шансов (ОШ) рассчитан оптимальный пороговый балл для определения риска развития рецидива СОД, равный 3. То есть, если пациент набирает 3 и более балла, то прогноз развития в дальнейшем рецидива саркоидоза считается положительным, если менее 3 баллов - то прогноз отрицательный.
Шкала оценки риска рецидивирующего течения саркоидоза у военнослужащих (шкала КФТ-35)

\begin{tabular}{|l|c|}
\hline \multicolumn{1}{|c|}{ Фактор риска } & Балл \\
\hline Возраст более 35 лет & 1 \\
\hline Наличие клинических проявлений & 1 \\
\hline ФЖЕЛ менее 85\% от должного & 1 \\
\hline Лечение ГКС & 1 \\
\hline $\begin{array}{l}\text { 3 и более балла — положительный прогноз развития } \\
\text { рецидива саркоидоза }\end{array}$ \\
\hline
\end{tabular}

Заключение. Таким образом, в проведенной нами работе установлено, что у военнослужащих в подавляющем числе случаев $(85,5 \%)$ диагностируется I и II стадия саркоидоза органов дыхания, часто $(72 \%)$ с бессимптомным течением заболевания. Результаты исследования позволяют выделить ряд важных проблем, возникающих в военно-лечебных организациях при ведении больных саркоидозом. Среди них нередкое использование инвазивных хирургических методов верификации диагноза, назначение системных ГКС пациентам с впервые выявленным саркоидозом бессимптомного течения, отсутствие рутинных лабораторных маркеров, позволяющих достоверно оценить активность гранулематозного процесса у молодых пациентов.

Анализ качества жизни заболевших саркоидозом военнослужащих с использованием опросника SHQ показал, что, несмотря на преобладание бессимптомных форм течения заболевания, качество жизни у данной профессиональной группы снижено. Факторами риска, достоверно ассоциированными с рецидивирующим течением саркоидоза у военнослужащих, являются возраст более 35 лет, наличие клинических проявлений, ФЖЕЛ менее 85\%, лечение ГКС в анамнезе. На основании полученных данных разработана шкала прогноза рецидивирующего течения саркоидоза у молодых пациентов (КФТ-35), обладающая высокой прогностической ценностью (82,4\%). Таким образом, целесообразно внедрить в алгоритм ведения больных саркоидозом из числа военнослужащих оценку прогноза по предложенной шкале. У пациентов, набравших 3 и более балла, рекомендуется оптимизировать сроки динамического наблюдения в первый год заболевания, а именно: сократить интервалы между контрольными обследованиями до 2 мес. 


\section{ЛИТЕРАТУРА}

1. Диагностика и лечение саркоидоза: резюме федеральных согласительных клинических рекомендаций. Классификация, этиопатогенез, клиника: ч. 1 / А.Г. Чучалин, А.А. Визель, М.М. Илькович [и др.] // Вестник современной клинической медицины. - 2014. - Т. 7 , вып. 4. - С.62-70.

2. Диагностика и лечение саркоидоза: резюме федеральных согласительных клинических рекомендаций. Диагностика, лечение, прогноз: ч. 2 / А.Г. Чучалин, А.А. Визель, М.М. Илькович [и др.] // Вестник современной клинической медицины. - 2014. - Т. 7, вып. 5. - С.73-81.

3. ATS/ERS/WASOG statement on sarcoidosis. American Thoracic Society / G.W. Hunninghake, U. Costabel, M. Ando [et al.]; European Respiratory Society/World Association of Sarcoidosis and other Granulomatous Disorders // Sarcoidosis Vasc. Diffuse Lung Dis. 1999. — Vol. 16, № 2. — P.149-173.

4. James, D. Epidemiology of sarcoidosis / D. James // Sarcoidosis. - 1992. - Vol. 9, № 2. - P.79-87.

5. Jajosky, P. Sarcoidosis diagnoses among U.S. military personnel: trends and ship assignment associations / P. Jajosky // Amer. J. Prev. J. Med. — 1998. — Vol. 14, № 3 - Р.176-183.

6. Диагностика и лечение пациентов с саркоидозом в многопрофильном военном стационаре. Предварительные итоги / А.А. Зайцев, Д.Н. Антипушина, И.В. Сивокозов, С.А. Чернов // Военно-медицинский журнал. - 2012. № 9. - С.35-41.

\section{REFERENSES}

1. Diagnostika i lechenie sarkoidoza: rezyume federal'nyh soglasitel'nyh klinicheskih rekomendacii. Klassifikaciya, etiopatogenez, klinika: ch. 1 [Diagnosis and treatment of sarcoidosis: a summary of federal consensus clinical guidelines. Classification, etiopathogenesis, clinical: part 1] / A.G. Chuchalin, A.A. Vizel', M.M. Il'kovich [i dr.] // Vestnik sovremennoi klinicheskoi mediciny [Bulletin of contemporary clinical medicine]. — 2014. - T. 7, vyp. 4. S.62-70.

2. Diagnostika i lechenie sarkoidoza: rezyume federal'nyh soglasitel'nyh klinicheskih rekomendacii. Diagnostika, lechenie, prognoz: ch. 2 [Diagnosis and treatment of sarcoidosis: a summary of federal consensus clinical guidelines. Diagnosis, treatment, prognosis: part 2] / A.G. Chuchalin, A.A. Vizel', M.M. Il'kovich [i dr.] // Vestnik sovremennoi klinicheskoi mediciny [Bulletin of contemporary clinical medicine]. — 2014. - T. 7, vyp. 5. S.73-81.

3. ATS/ERS/WASOG statement on sarcoidosis. American Thoracic Society / G.W. Hunninghake, U. Costabel, M. Ando [et al.]; European Respiratory Society/World Association of Sarcoidosis and other Granulomatous Disorders // Sarcoidosis Vasc. Diffuse Lung Dis. 1999. — Vol. 16, № 2. - P.149-173.

4. James, D. Epidemiology of sarcoidosis / D. James // Sarcoidosis. - 1992. — Vol. 9, № 2. - R.79-87.

5. Jajosky, P. Sarcoidosis diagnoses among U.S. military personnel: trends and ship assignment associations / P. Jajosky // Amer. J. Prev. J. Med. - 1998. — Vol. 14, № 3 -P.176-183.

6. Diagnostika i lechenie pacientov s sarkoidozom v mnogoprofil'nom voennom stacionare. Predvaritel'nye itogi [Diagnosis and treatment of patients with sarcoidosis in versatile military hospital. Preliminary results] / A.A. Zaicev, D.N. Antipushina, I.V. Sivokozov, S.A. Chernov // Voennomedicinskii zhurnal [Military Medical Journal]. — 2012. № 9. - S.35-41.

\section{ЭФФЕКТИВНОСТЬ ДАБИГАТРАНА ЭТЕКСИЛАТА В ЛЕЧЕНИИ ВАРФАРИН-ИНДУЦИРОВАННОГО ТРОМБОЗА ПОСЛЕ АРТРОПЛАСТИКИ ТАЗОБЕДРЕННОГО СУСТАВА}

ЛЮДМИЛА ВАЛЕНТИНОВНА БОРИСОВА, врач клинический фармаколог ФГБУ «Федеральный центр травматологии, ортопедии и эндопротезирования» Минздрава России, Чебоксары, Россия, тел. +7(8352)-30-57-81,

e-mail: Iborisova@orthoscheb.com

СВЕТЛАНА НИКОЛАЕВНА ДИДИЧЕНКО, врач-терапевт ФГБУ «Федеральный центр травматологии, ортопедии и эндопротезирования» Минздрава России, Чебоксары, Россия, тел. +7(8352)-30-57-05,

e-mail: mishina@orthoscheb.com

АЛЕНА ВЛАДИСЛАВОВНА ОРЛОВА, канд. мед. наук, врач-методист ФГБУ «Федеральный центр травматологии, ортопедии и эндопротезирования» Минздрава России, Чебоксары, Россия, тел. +7(8352)-30-57-08, e-mail: aorlova@orthoscheb.com

Реферат. Цель — показать вариант лечения дабигатраном этексилатом варфарин-индуцированного тромбоза после эндопротезирования тазобедренного сустава. Материал и методы. Клиническое наблюдение. Результаты и их обсуждение. Основной причиной развития тромбоза глубоких вен оперированной нижней конечности после эндопротезирования тазобедренного сустава явилась антикоагулянтная профилактика варфарином на фоне низкого уровня протеина С. При этом нарушилась инактивация витамин-К-зависимых факторов свертывания (Va и VIIla), ответственных за выработку тромбина, что привело к его избыточной продукции и соответственно повышению тромбогенности. Длительная антикоагулянтная терапия (в течение 6 мес) дабигатраном этексилатом позволила достичь высоких положительных клинических результатов. Выводы. С целью предупреждения развития тромботических осложнений у пациентов с тромботическим анамнезом перед назначением варфарина целесообразно определить уровень физиологических антикоагулянтов в крови, в том числе уровень протеина С.

Ключевые слова: варфарин-индуцированный тромбоз, эндопротезирование, дабигатран этексилат, протеин C. 


\title{
EFFICIENCY OF DABIGATRAN ETEXILATE IN TREATMENT OF WARFARIN-INDUCED THROMBOSIS AFTER HIP ARTHROPLASTY
}

LUDMILA V. BORISOVA, clinical pharmacologist of FSBI "The Federal centre of traumatology, orthopedics and arthroplasty» of Russian Ministry of Health, Cheboksary, Russia, tel. +7(8352)-30-57-81, e-mail: Iborisova@orthoscheb.com SVETLANA N. DIDICHENKO, general practitioner of FSBI "The Federal centre of traumatology, orthopedics and arthroplasty» of Russian Ministry of Health, Cheboksary, Russia, tel. +7(8352)-30-57-05, e-mail: mishina@orthoscheb.com

ALENA V. ORLOVA, Candidate of Medical Science, doctor of metodical department of FSBI «The Federal centre of traumatology, orthopedics and arthroplasty» of Russian Ministry of Health, Cheboksary, Russia, tel. +7(8352) 30-57-08, e-mail: aorlova@ orthoscheb.com

\begin{abstract}
The goal is to show a treatment option with dabigatran etexilate for warfarin-induced thrombosis after hip replacement arthroplasty. Material and methods. Clinical observation. Results and discussion. The main reason for the development of deep vein thrombosis of operated lower limb after hip replacement arthroplasty was anticoagulant warfarin prophylaxis against the backdrop of the low level of protein $\mathrm{C}$. Therefore the inactivation of vitamin-K dependent coagulation factors (Va и VIIla) responsible for the production of thrombin was disturbed, which led to its excessive production and consequent increase in thrombogenicity. Long-term anticoagulant therapy (during 6 month) with dabigatran-etexilate helped to achieve high positive clinical results. Conclusions. In order to prevent the development of thrombotic complications in patients with thrombotic history, before prescribing warfarin is expedient to determine the level of physiological anticoagulants in the blood including the level of protein C.

Key words: warfarin-induced thrombosis, joint replacement, dabigatran etexilate, protein C
\end{abstract}

B енозные тромбоэмболические осложнения (ВТЭО) занимают одно из первых мест по частоте возникновения осложнений после артропластики крупных суставов. По данным зарубежных авторов, при отсутствии профилактики возникновение тромбоэмболических осложнений при обширных ортопедических вмешательствах достигает 40-60\% $[4,10]$. В 0,7-30,0\% случаев тромбоз приводит к тромбоэмболии легочной артерии [6], которая в 0,1-3,0\% случаев заканчивается летально [5].

Одной из причин развития тромбозов является влияние некоторых лекарственных средств, таких как гепарин и антагонисты витамина К (варфарин, аценокумарол и др.) [1]. Варфарин является антагонистом всех витамин-К-зависимых фракторов свертывания крови, которые включают в себя II, VII, IX, X, в том числе фризиологические антикоагулянты - протеин C (PC) и протеин S (PS). Причем снижение VII фактора, PC и PS происходит быстрее, чем сывороточных фракторов II, IX и X (прокоагулянты), что связано с их более коротким периодом полувыведения [7]. РС стимулирует выделение тканевого активатора плазминогена эндотелиальными клетками, тем самым активирует фибринолиз. Под действием варфарина снижается фиибринолитическая активность крови и усиливается тромбоз микроциркуляторного русла, тем самым вызывая некротические повреждения кожи $[3,8]$.

Предрасполагающими факторами к развитию тромбозов на фоне приема антагонистов витамина К являются: средний и пожилой возраст, женский пол (частота встречаемости по сравнению с мужчинами 4:1), ожирение, высокая начальная доза, наследственный дефицит противосвертывающих фракторов крови: протеина C (PC), протеина S (PS) и антитромбина III (АT III) [2, 8].

По данным зарубежной литературы, частота возникновения варфариновых тромбозов-некрозов (в основе которых лежит нарушение проходимости мелких сосудов в результате окклюзии) составляет 0,01-0,1\% лиц, получающих варфрарин [8, 9]. В
90\% случаев тромбоз развивается на 3-6-е сут от начала приема антикоагулянта [2, 3, 8].

\section{Клинический случай}

Пациентка T., 1935 г.р. (78 лет), поступила в Федеральное государственное бюджетное учреждение «Федеральный центр травматологии, ортопедии и эндопротезирования» Минздрава России г. Чебоксары (далее Центр) 23.08.2013 г. с диагнозом «закрытый медиальный перелом шейки левой бедренной кости со смещением отломков (травма от 21.08.13)» с целью проведения оперативного лечения - эндопротезирования тазобедренного сустава. Из перенесенных заболеваний следует отметить гипертоническую болезнь, отслойку сетчатки правого глаза в 2000 г., лакунарные острые нарушения мозгового кровообращения по ишемическому типу в 2006 и 2011 гг. с восстановлением функций, мультифокальный атеросклероз. Постоянно принимает торасемид 5 мг/сут, эналаприл 10 мг/сут, нифедипин прологированного действия 20 мг/сут, ацетилсалициловую кислоту 75 мг/сут. Рост 160 см, вес 95 кг, ИМТ 37,1 кг/м².

При госпитализации, по данным ультразвукового дуплексного сканирования (УЗДС) сосудов нижних конечностей, отмечено относительное снижение кровотока глубоких вен голени с обеих сторон. По данным коагулограммы - склонность к гиперкоагуляции (таблица). С учетом имеющейся сопутствующей патологии, ограничения подвижности пациентки в результате травмы, данных лабораторных показателей предоперационная антикоагулянтная профилактика проводилась гепарином в дозе 2,5 тыс. ЕД 4 раза в сут подкожно в комбинации с внутривенным введением пентоксифиллина и никотиновой кислоты в течение 3 дней.

26 августа 2013 г. выполнено тотальное эндопротезирование левого тазобедренного сустава под спинальной анестезией наропином. Интраоперационная кровопотеря составила 200 мл.

В первые сутки после операции (27.08.13 г.) выполнено контрольное УЗДС вен нижних конечностей. Сохраняется снижение скоростных показателей в 
Тактика ведения пациента по данным коагулограммы

и результатов УЗДС вен нижних конечностей

\begin{tabular}{|c|c|c|c|c|c|c|c|c|c|}
\hline \multirow[b]{2}{*}{ Дата } & \multicolumn{9}{|c|}{ Лабораторные данные + результат УЗДС вен нижних конечностей + лечение } \\
\hline & $\begin{array}{c}\text { Фибриноген, } \\
\text { 2/л, норма } 2-4\end{array}$ & $\begin{array}{l}\text { АЧТВ, } \\
\text { норма } \\
24-35\end{array}$ & $\begin{array}{c}\text { ПТВ, c, } \\
\text { норма } \\
9,5-13\end{array}$ & $\begin{array}{c}\text { МHO, } \\
\text { норма } \\
0,8-1,4\end{array}$ & $\begin{array}{c}\text { РФМК, } \\
\text { мг\%, } \\
\text { норма <4 }\end{array}$ & $\begin{array}{c}\text { Тромбиновое } \\
\text { время, } c \text {, } \\
\text { норма } 11-18\end{array}$ & $\begin{array}{c}\text { AT III, } \\
\%, \\
\text { Hopma } \\
83-125\end{array}$ & $\begin{array}{l}\text { Д-димер, } \\
\text { нг/мл, } \\
\text { норма } \\
<255 \\
\end{array}$ & $\begin{array}{c}\text { PC, \% } \\
\text { норма } \\
70-140\end{array}$ \\
\hline \multirow[t]{3}{*}{ 23.08.2013 г. } & 5 & 24,6 & 11,4 & 1,018 & 22 & 14 & 83 & 376 & - \\
\hline & \multicolumn{9}{|c|}{$\begin{array}{l}\text { УЗДС: глубокие и поверхностные вены проходимы, без тромбов, снижение скоростных показателей в } \\
\text { системе глубоких вен голени слева }\end{array}$} \\
\hline & \multicolumn{9}{|c|}{ Профиллактика: гепарин 2,5 тыс. ЕД 4 раза в сут подкожно, пентоксифиллин, никотиновая кислота } \\
\hline 26.08.2013 г. & \multicolumn{9}{|c|}{$\begin{array}{l}\text { Тотальное цементное эндопротезирование левого тазобедренного сустава Zimmer ZCA 51-Muller straight } \\
\text { stand. stem 11,25-Protasul 32/+0 с костной аутопластикой }\end{array}$} \\
\hline \multirow[t]{3}{*}{27.08 .2013 г. } & 4,29 & 33,4 & 13 & 1,05 & 12 & 15,7 & 28,7 & 1019 & - \\
\hline & \multicolumn{9}{|c|}{$\begin{array}{l}\text { УЗДС: глубокие и поверхностные вены проходимы, без тромбов, снижение скоростных показателей в } \\
\text { системе глубоких вен голени слева }\end{array}$} \\
\hline & \multicolumn{9}{|c|}{ Лечение: гепарин 5 тыс. ЕД 4 раза в сут подкожно, электролиты } \\
\hline \multirow[t]{2}{*}{30.08 .2013 г. } & \multirow{2}{*}{\multicolumn{9}{|c|}{$\begin{array}{l}\text { УЗДС: слева в ГБВ проксимально нечеткие слабоэхогенные структуры пристеночного характера } \\
\text { Лечение: гепарин } 25 \text { тыс. ЕД с V=0,8 мл/ч, с переходом на введение гепарина } 5 \text { тыс. ЕД } 5 \text { раз в сут под- } \\
\text { кожно, электролиты, пентоксифиллин, никотиновая кислота }\end{array}$}} \\
\hline & & & & & & & & & \\
\hline \multirow[t]{2}{*}{31.08 .2013 г. } & 5,91 & 40,7 & 14,3 & 1,13 & 24 & 19,2 & 58,4 & 607 & - \\
\hline & \multicolumn{9}{|c|}{$\begin{array}{l}\text { УЗДС: слева в ГБВ проксимально нечеткие слабоэхогенные структуры пристеночного характера без от- } \\
\text { рицательной динамики }\end{array}$} \\
\hline 01.09.2013 г. & \multicolumn{9}{|c|}{$\begin{array}{l}\text { Лечение: переход на введение гепарина } 5 \text { тыс. ЕД } 5 \text { раз в сут подкожно + варфарин } 5 \text { мг внутрь + электро- } \\
\text { литы + пентоксифиллин + никотиновая кислота }\end{array}$} \\
\hline \multirow[t]{4}{*}{ 06.09.2013 г. } & 4,4 & 42,5 & 68,7 & 5,64 & 26 & 15,2 & 79,1 & 920 & $\begin{array}{c}30,6 \\
(\text { норма - } \\
70-140 \%)\end{array}$ \\
\hline & \multicolumn{9}{|c|}{$\begin{array}{l}\text { УЗДС: в просвете ОБВ, ПБВ, ГБВ, ПКВ, глубоких вен голени (ЗББВ - задняя большеберцовая вена, } \\
\text { МБВ - малоберцовая вена) гипоизоэхогенные тромботические массы без полной окклюзии, на уровне } \\
\text { ОБВ определяется незначительный пристеночный кровоток, головка тромба без явных УЗ-признаков фло- } \\
\text { тации; ниже в дистальном направлении просвет глубоких вен левой нижней конечности (н/к) полностью } \\
\text { окклюзирован тромботическими массами. Отмечается усиление и ускорение венозного кровотока в по- } \\
\text { верхностной системе (БПВ - большая подкожная вена, МПВ - малая подкожная вена) левой н/к компен- } \\
\text { саторного характера. Отек мягких тканей левой н/к умеренно выраженный, с элементами гипергидратации }\end{array}$} \\
\hline & \multicolumn{9}{|c|}{ Лечение: отмена гепарина и варфарина, переливание 1 дозы СзП, пневмокомпрессия } \\
\hline & & 37,2 & 42,9 & 3,5 & - & - & - & - & - \\
\hline \multirow[t]{3}{*}{ 07.09.2013 г. } & 4,71 & 38,2 & 51,9 & 4,19 & 21 & 13,9 & 73,9 & - & 一 \\
\hline & \multicolumn{9}{|c|}{$\begin{array}{l}\text { УЗДС: в просвете ОБВ, ПБВ, ГБВ, ПКВ, глубоких вен голени (ЗББВ, МБВ) сохраняются гипоизоэхогенные } \\
\text { тромботические массы без полной окклюзии, на уровне ОБВ определяется незначительный пристеночный } \\
\text { кровоток, головка тромба без явных УЗ-признаков флотации; ниже в дистальном направлении просвет глу- } \\
\text { боких вен левой н/к полностью окклюзирован тромботическими массами. Отмечается усиление и ускоре- } \\
\text { ние венозного кровотока в поверхностной системе (БПВ, МПВ) левой н/к компенсаторного характера. Отек } \\
\text { мягких тканей левой н/к умеренно выраженный, с элементами гипергидратации }\end{array}$} \\
\hline & \multicolumn{9}{|c|}{ Лечение: переливание 1 дозы СЗП, пневмокомпрессия } \\
\hline \multirow[t]{2}{*}{ 08.09.2013 г. } & - & 35 & 28,2 & 2,29 & - & - & - & - & - \\
\hline & \multicolumn{9}{|c|}{ Лечение: клексан 0,4 мл 2 раза в сут п/к } \\
\hline 09.09.2013 г. & \multicolumn{9}{|c|}{$\begin{array}{l}\text { УЗДС: в просвете ОБВ, ПБВ, ГБВ, ПКВ, глубоких вен голени (ЗББВ, МБВ) сохраняются гипоизоэхогенные } \\
\text { тромботические массы без полной окклюзии, на уровне ОБВ определяется незначительный пристеночный } \\
\text { кровоток, головка тромба без явных УЗ-признаков фрлотации; ниже в дистальном направлении просвет } \\
\text { глубоких вен левой н/к полностью окклюзирован тромботическими массами. Сохраняется перераспределе- } \\
\text { ние венозного кровотока в поверхностную систему (БПВ, МПВ) левой н/к компенсаторного характера. Отек } \\
\text { мягких тканей левой н/к незначительно выраженный, с элементами гипергидратации }\end{array}$} \\
\hline 10.09.2013 г. & 4,6 & 27,7 & 13,1 & 1,171 & 28 & 12 & 101 & 789 & - \\
\hline 13.09.2013 г. & \multicolumn{9}{|c|}{$\begin{array}{l}\text { УЗДС: в просвете ОБВ, ПБВ, ГБВ, ПКВ, глубоких вен голени (ЗББВ, МБВ) сохраняются гиперэхогенные } \\
\text { тромботические массы. На всем протяжении глубоких вен, больше в бедренном сегменте, определяется } \\
\text { незначительный пристеночный кровоток (начальные процессы реканализации). Сохраняется перераспре- } \\
\text { деление венозного кровотока в поверхностную систему (БПВ, МПВ) левой н/к компенсаторного характера }\end{array}$} \\
\hline $\begin{array}{l}\text { 16.09.2013 г.- } \\
01.04 .2014 \text { г. }\end{array}$ & \multicolumn{9}{|c|}{ Лечение: ежедневный прием дабигатрана этексилата 220 мг 1 раз в сут внутрь (амбулаторно) } \\
\hline 01.04.2014 г. & \multicolumn{9}{|c|}{$\begin{array}{l}\text { УЗДС справа: НПВ проходима. Проходимость глубоких и поверхностных вен бедра, ПКВ, вен голени в } \\
\text { зонах, доступных для локации, сохранена. } \\
\text { УЗДС слева: НПВ проходима. ОБВ проходима. В просвете ПБВ сохраняются пристеночные структуры, } \\
\text { кровоток центрального характера. ГБВ, ПКВ проходимы, пристеночные наложения в просвете ПКВ. Вены } \\
\text { голени: кровоток лоцируется в неполном объеме с пристеночными наложениями. Перераспределение } \\
\text { кровотока в поверхностную систему }\end{array}$} \\
\hline
\end{tabular}


системе глубоких вен голени слева. По данным коагулограммы, выявлено понижение АТ III до 58,7\%, повышение уровня Д-димера до 1019 нг/мл, что свидетельствует о коагулопатии потребления. С учетом фракторов риска развития тромбоэмболических осложнений продолжено введение гепарина (5 тыс. ЕД 4 раза в сут подкожно), введение озонированного раствора натрия хлорида, пневмокомпрессия, активизация пациентки - ходьба с опорой на костыли.

На пятые сутки после операции (30.08.13 г.) повторно выполнено контрольное УЗДС вен нижних конечностей: в просвете глубокой бедренной вены (ГБВ) слева выявлены нечеткие слабоэхогенные структуры, кровоток при дистальной компрессии лоцировался в неполном объеме, пристеночного характера. При визуальном осмотре левой нижней конечности клинических проявлений острого тромбоза не выявлено. В связи с развитием острого неокклюзионного фрлеботромбоза глубоких вен левой нижней конечности пациентка переведена на инфузионное введение гепарина в дозе 800 ЕД/ч в течение суток, с последующим переводом на подкожное введение по 5 тыс. ЕД 5 раз в сут, к лечению добавлено введение никотиновой кислоты и пентоксифиллина. Спустя сутки, по данным коагулограммы, активированное частичное тромбопластиновое время (АЧТВ) удлинилось до 40,7 с, АТ III сохранялся на прежнем уровне, Д-димеры в динамике снизились в 1,8 раза. На вторые сутки от начала лечения тромбоза гепарином (01.09.13 г.) в терапию подключен варфарин в дозе 5 мг 1 раз в сут внутрь. 04.09.13 г. выполнен анализ коагулограммы: сохраняется незначительное удлинение АЧТВ до 37,3 с, междунароное нормализованное отношение (МНО) достигло целевых лечебных значений $-2,997$.

Через 5 дней после начала приема варфарина, по данным УЗДС, отмечается отрицательная динамика в виде прогрессирования фолеботромбоза и вовлечения в патологический процесс проксимальных отделов венозной системы левой нижней конечности до уровня общей бедренной вены (ОБВ), в дистальном направлении просвет глубоких вен левой нижней конечности полностью окклюзирован тромботическими массами, незначительный пристеночный кровоток. По результатам коагулограммы, сохраняются повышенные значения АЧТВ до 42,5 с, МНО выросло до 5,64, РФМК - до 26 мг\%, Д-димер увеличился в 1,5 раза от предыдущего значения (до 920 нг/мл). Прогрессирование проксимальных тромботических изменений в сосудах левой нижней конечности на 5-й день приема варфарина и отсутствие тромбоцитопении (уровень тромбоцитов варьировал от $294 \times 10^{9}$ до $426 \times 10^{9}$ ) позволило заподозрить варфрарин-индуцированный тромбоз, обусловленный истощением физиологических антикоагулянтов. В связи с этим целенаправленно исследована кровь на РС и выявлено значительное снижение его уровня до $30,6 \%$ (норма - 70-140\%) [2].

Проведена коррекция антикоагулянтной терапии: отмена варфарина, введение донаторов фризиологических антикоагулянтов - свежезамороженной плазмы (СЗП). При достижении МНО до 2,29, антикоагулянтная терапия проводилась клексаном в дозе 0,4 мг 2 раза в сут подкожно до выписки (15.09.13 г.). По данным контрольной УЗДС вен нижних конечностей от 13.09.13 г., отмечается некоторая положительная динамика в виде начальных процессов реканализации на всем протяжении глубоких вен, больше в бедренном сегменте. По данным коагулограммы, при выписке обращали на себя внимание сохраняющиеся высокие цифры Д-димера (786 нг/мл), остальные показатели были в пределах допустимых значений. Пациентка в удовлетворительном состоянии выписана из стационара с рекомендациями наблюдения у ангиохирурга по месту жительства.

В амбулаторных условиях профилактика рецидива тромбоза проводилась пероральным антикоагулянтом - дабигатраном этексилатом в дозе 220 мг 1 раз в сут внутрь в течение 6 мес. При очередном осмотре в поликлинике Центра в апреле 2014 г. выполнено контрольное УЗДС вен нижних конечностей с пораженной стороны, отмечен достаточно положительный результат лечения в виде очищения от тромботических масс НПВ (наружная подвздошная вена) и ОБВ; в просвете ПБВ (подкожная бедренная вена), ПКВ (подколенная вена) и в венах голени сохранялись пристеночные структуры; ГБВ, ПКВ проходимы.

Результаты и их обсуждение. В представленном клиническом случае имеет место прогрессирование развития тромбоза глубоких вен оперированной нижней конечности после эндопротезирования тазобедренного сустава, развившегося на 5-й день терапии варфарином. Дообследование выявило низкий уровень одного из витамин-К-зависимых факторов антикоагуляции - протеина С более чем в 2 раза от нормальных значений. Нельзя исключить наличие у пациентки как наследственный характер дефицита данного белка (исследование его содержания до лечения не проводилось), так и функциональный (на фоне подавляющего действия на этот антикоагулянт варфарина). В результате дефицита протеина С нарушилась инактивация факторов свертывания Va и VIIIa, ответственных за выработку тромбина, что привело к его избыточной продукции и соответственно повышению тромбогенности [2, 3, 8].

После отмены варфарина антикоагулятная терапия заключалась в восполнении фризиологических противосвертывающих факторов (восполнение протеина C, протеина S, антитромбина III и др.) путем введения свежезамороженной плазмы, с назначением низкомолекулярного гепарина - клексана, обладающего высокой анти-Ха-активностью и низкой анти-ІІа, или антитромбиновой активностью, а также средств, улучшающих микроциркуляцию пентоксифиллина и никотиновой кислоты. В амбулаторных условиях в течение 6 мес пациентка принимала дабигатран этексилат в дозе 220 мг/сут внутрь. Механизм действия данного препарата направлен на ингибирование свободного тромбина, фрибриносвязанного тромбина, тромбинассоциированной агрегации тромбоцитов, а влияние на уровень витамин-К-зависимых фракторов свертывания отсутствует. На фоне лечения дабигатраном этексилатом выявлен хороший клинический эффект с 
восстановлением проходимости НПВ и ОБВ, а также признаками удовлетворительной реканализации ПБВ, ПКВ, вен голени.

Выводы. Учитывая тромботический анамнез (отслойка сетчатки правого глаза в 2000 г., лакунарные острые нарушения мозгового кровообращения по ишемическому типу в 2006, 2011 гг. с восстановлением функций), можно было заподозрить у пациентки наличие скрытой тромбофилии. С целью предупреждения развития тромботических осложнений перед назначением варфарина целесообразно определять уровень физиологических антикоагулянтов в крови, в том числе уровень протеина С. Надеемся, что описанный выше клинический случай и полученный нами опыт найдет применение в прогнозировании и терапии варфрарин-индуцированных тромбозов.

\section{ЛИТЕРАТУРА}

1. Васильев, С.А. Тромбозы и тромбофилии: классификация, диагностика, лечение, профилактика / С.А. Васильев, В.Л. Виноградов, А.Н. Смирнов [и др.] // Русский медицинский журнал. - 2013. - № 17. - С.896.

2. Chan, Y.C. Warfarin induced skin necrosis / Y.C. Chan, D. Valentini, A.O. Mansfield, G. Stensby // Br. J. Surg. 2000. - Vol. 87(3). - P.266-272.

3. Essex, D.W. Late-onset warfarin-induced skin necrosis: case report and review of the literature / D.W. Essex, S.S. Wynn, D.K. Jin // Am. J. Hematol. - 1998. Vol. 57(3). - P.233-237.

4. Geerts, W.H. Prevention of venous thromboembolism: The Seventh ACCP Conference on Antithrombotic and Thrombolytic Therapy / W.H. Geerts, G.F. Pineo, J.A. Heit [et al.] // Chest. - 2004. - Vol. 126 (suppl. 3). P.338S-400S.

5. Haas, S. Deep vein thrombosis. Beyond the operating table / S. Haas // Orthopedics. — 2000. — Vol. 23, № 6. P.629-632.

6. Heit, J.A. Prevention of venous thromboembolism: Sixth American college of chest physiciane consensus conference on antithrombotic therapy / J.A. Heit, G.P. Clagett // Chest. — 2001. - Vol. 119. - P.13251755.

7. Ikezoe, T. Trombomodulin/activated protein C system in septic disseminated intravascular coagulation / T. Ikezoe // J. Intensive Care. - 2015. - Vol. 3(1). — URL: 1.doi: 10.1186/s40560-014-0050-7.eCollection 2015

8. Irwin, R.S. Warfarin induced skin necrosis / R.S. Irwin, J.M. Rippe // Irwin and Rippe is Intensive Care Medicine. $6^{\text {th }}$ ed. - Philadelphia: Lippincott Williams, 2007. P.2267.
9. Warkentin, T.E. Multicentric warfarin-induced skin necrosis complicating heparin-induced thrombocytopenia / T.E. Warkentin, W.M. Sikov, D.P. Lillicrap // Am. J. Hematol. - 1999. - Vol. 62(1). - P.44-48.

10. White, R.H. Incidence and time course of thromboembolic outcomes following total hip or knee arthroplasty / R.H. White, P.S. Romano, H. Zhou [et al.] // Arch. Intern. Med. — 1998. — Vol. 158, № 14. — P.1525-1531.

\section{REFERENCES}

1. Vasil'ev, S.A. Trombozy i trombofilii: klassifikaciya, diagnostika, lechenie, profilaktika [Thrombosis and thrombophilia: classification, diagnosis, treatment, prevention] / S.A. Vasil'ev, V.L. Vinogradov, A.N. Smirnov [i dr.] // Russkii medicinskii zhurnal [Russian medical journal]. - 2013. — № 17. - S.896.

2. Chan, Y.C. Warfarin induced skin necrosis / Y.C. Chan, D. Valentini, A.O. Mansfield, G. Stensby // Br. J. Surg. 2000. - Vol. 87(3). - P.266-272.

3. Essex, D.W. Late-onset warfarin- induced skin necrosis: case report and review of the literature / D.W. Essex, S.S. Wynn, D.K. Jin // Am. J. Hematol. - 1998. Vol. 57(3). - P.233-237.

4. Geerts, W.H. Prevention of venous thromboembolism: The Seventh ACCP Conference on Antithrombotic and Thrombolytic Therapy / W.H. Geerts, G.F. Pineo, J.A. Heit [et al.] // Chest. - 2004. - Vol. 126 (suppl. 3). P.338S-400S.

5. Haas, $S$. Deep vein thrombosis. Beyond the operating table / S. Haas // Orthopedics. - 2000. - Vol. 23, № 6. - P.629-632.

6. Heit, J.A. Prevention of venous thromboembolism: Sixth American college of chest physiciane consensus conference on antithrombotic therapy / J.A. Heit, G.P. Clagett // Chest. - 2001. - Vol. 119. - P.13251755.

7. Ikezoe, T. Trombomodulin/activated protein C system in septic disseminated intravascular coagulation / T. Ikezoe // J. Intensive Care. - 2015. - Vol. 3(1). — URL: 1.doi: 10.1186/s40560-014-0050-7.eCollection 2015

8. Irwin, R.S. Warfarin induced skin necrosis / R.S. Irwin, J.M. Rippe // Irwin and Rippe is Intensive Care Medicine. $6^{\text {th }}$ ed. - Philadelphia: Lippincott Williams, 2007. P.2267.

9. Warkentin, T.E. Multicentric warfarin-induced skin necrosis complicating heparin-induced thrombocytopenia / T.E. Warkentin, W.M. Sikov, D.P. Lillicrap // Am. J. Hematol. - 1999. - Vol. 62(1). - P.44-48.

10. White, R.H. Incidence and time course of thromboembolic outcomes following total hip or knee arthroplasty / R.H. White, P.S. Romano, H. Zhou [et al.] // Arch. Intern. Med. — 1998. — Vol. 158, № 14. — P.1525-1531.

\title{
МОНИТОРИНГ КАЧЕСТВА ЖИЗНИ НАСЕЛЕНИЯ С ПОМОЩЬЮ ОПРОСНИКА SF-36 КАК ОПЕРЕЖАЮЩИЙ ИНДИКАТОР ПРОГНОЗИРОВАНИЯ ЭПИДЕМИОЛОГИЧЕСКОЙ ОБСТАНОВКИ ПО ТУБЕРКУЛЕЗУ
}

\author{
АЛЕКСЕЙ НИКОЛАЕВИЧ ДАНИЛОВ, канд. меД. наук, доцент кафедры эпидемиологии ГБОУ ВПО «Саратовский \\ государственный медицинский университет им. В.И. Разумовского» Минздрава России, Саратов, Россия, \\ тел. 8-845-2-26-16-90, e-mail: dispans@san.ru \\ Реферат. Цель исследования - проанализировать возможность использования показателя качества жизни как \\ опережающего индикатора при оценке эпидемиологической обстановки по туберкулезу на конкретной территории. \\ Mameриал и методы. C помощью опросника SF-36 были изучены показатели качества жизни у 4861 жителя
}


Саратовской области в период флюорографического обследования в 2010-2013 гг. Результаты и их обсуждение. Выявлено, что при снижении качества жизни населения увеличивается заболеваемость туберкулезом. Установлено, что, по данным опросника SF-36, у 2451 человека, проживающего в шести районах Саратовской области, снижение качества жизни на одну условную единицу в текущем году прогнозирует рост заболеваемости туберкулезом на 0,53\% в последующем. Расхождения между прогнозируемой в текущем году и реальной заболеваемостью туберкулезом в последующем на конкретной территории Саратовской области по разработанной методике варьировали в пределах $25,3-6,7 \%$ и в среднем составили 15,8\%. Выявленные закономерности позволяют рекомендовать применение данного метода в практическом здравоохранении. Заключение. Мониторинг качества жизни населения с помощью опросника SF-36 может выступать в качестве опережающего индикатора при прогнозировании эпидемиологической обстановки по туберкулезу на конкретной территории.

Ключевые слова: туберкулез, эпидемиология, прогнозирование, качество жизни.

\title{
MONITORING THE QUALITY OF LIFE USING A QUESTIONNAIRE SF-36 AS A LEADING INDICATOR PREDICTION EPIDEMIOLOGICAL SITUATION TUBERCULOSIS
}

\author{
ALEXEY N. DANILOV, Candidate of Medical Science, associate professor of the Department of epidemiology of SBEI HPE \\ «Saratov State Medical University of named after V.I. Razumovsky» of Russian Ministry of Health, Russia, Saratov, \\ tel.8-845-2-26-16-90, e-mail: dispans@san.ru
}

\begin{abstract}
Aim. To analyze the possibility of using the index of quality of life as a leading indicator when assessing the epidemiological situation of tuberculosis in a particular area. Material and methods. With use the SF-36 were studied quality of life of 4861 residents of the Saratov region in period 2010-2013. Results. Found that reducing the quality of life increases the incidence of tuberculosis. It was found that, according to SF-36 of 2451 people living in the six districts of the Saratov region reduced quality of life to one conventional unit this year, predicts growth of tuberculosis on $0,53 \%$ thereafter. Discrepancies between predicted in the current year and the actual incidence of tuberculosis in the future in a particular area of the Saratov region by the developed technique is ranged $25,3-6,7 \%$ and averaged $15,8 \%$. Revealed regularities allow us to recommend this method for use in medical practice. Conclusion. Monitoring the quality of life using the SF-36 may act as a leading indicator in predicting the epidemiological situation of tuberculosis in a particular area.
\end{abstract}

Key words: tuberculosis, epidemiology, prognosis, quality of life.

$B^{\mathrm{s}}$ ведение. Среди характеристик эпидемиологической обстановки по туберкулезу показатель заболеваемости относится к наиболее важным. Снижение этого параметра в течение нескольких лет свидетельствует об улучшении эпидемиологической обстановки, а увеличение - об ее ухудшении. Следует отметить, что этот показатель отражает только сам факт изменения эпидемиологической обстановки, но не раскрывает глубинные процессы, приводящие к этим изменениям. Так, например, в период с 2000 по 2007 г. в России наблюдалась четкая тенденция к снижению заболеваемости туберкулезом и ничего не предвещало ее роста в 2008-2009 гг. Однако при ретроспективном анализе можно отметить, что этот период совпал с началом мирового экономического кризиса [2]. Приведенные данные четко показывают, что заболеваемость туберкулезом определяется не только вероятностью тесного контакта человека с больным туберкулезом, но и наличием различных фракторов, снижающих резистентность организма человека к возбудителю. Среди этих факторов можно выделить социально-экономические, бытовые, экологические, производственные и многие другие [5, 8].

Во второй половине XX в. было проведено огромное количество исследований, посвященных анализу различных причин и их комбинаций, повышающих риск развития туберкулеза и, как следствие, ухудшающих эпидемиологическую ситуацию. Методика и идеология этих исследований крайне различались, а результаты проведенных исследований зачастую оказывались противоречивыми $[1,6,7]$.

На наш взгляд, перспективным направлением в плане поиска индикаторов, позволяющих прогнозировать изменения в эпидемиологической обстановке на ближайший период, может быть применение показателя качества жизни. Исследование качества жизни в настоящее время является надежным методом оценки общего благополучия не только индивида, но и групп людей, различных по возрасту, полу, профрессии и другим категориям населения и общества в целом [10]. При этом изучение качества жизни обеспечивает возможность получения таких характеристик здоровья, которые не могут быть идентифицированы никаким другим методом. В научной литературе имеется большое количество работ, посвященных анализу качества жизни больных с уже диагностированным туберкулезом [3, 4, 9], однако этот показатель в оценке и прогнозировании эпидемиологической обстановки до настоящего времени не использовался.

Цель исследования - проанализировать возможность использования показателя качества жизни как опережающего индикатора при оценке эпидемиологической обстановки по туберкулезу на конкретной территории.

Материал и методы. Результаты настоящего исследования получены в ходе анализа статистической отчетности Миздрава Саратовской области 
в период с 2010 по 2013 г. Кроме того, за указанный период с помощью опросника SF-36 были изучены показатели качества жизни у 4861 жителя Саратовской области в период флюорографического обследования. Опросник SF-36 (англ. - the Short Form-36) - это неспецифический опросник для оценки качества жизни пациента, широко используемый при проведении исследований качества жизни в странах Европы и США. Он был установлен для оценки качества жизни в Италии, Франции, Австралии и общей популяции США. В странах Европы и США были проведены исследования отдельных групп людей и получены результаты по нормам для здорового населения и для больных с различными хроническими заболеваниями (с распределением на группы соответственно возрасту и полу). Опросник отражает общее благополучие и степень удовлетворенности теми сторонами жизнедеятельности человека, которые влияют на состояние здоровья. SF-36 состоит из 36 вопросов, сгруппированных в восемь шкал: физическое функционирование; ролевая деятельность; телесная боль; общее здоровье; жизнедеятельность; социальное функционирование; эмоциональное состояние; психическое здоровье. Показатели каждой шкалы составлены таким образом, что чем выше значение показателя (от 0 до 100), тем лучше оценка по избранной шкале. Из них фрормируют два параметра: психологический и фризический компоненты здоровья. Для статистической обработки применяли пакеты программ «Microsoft Excel» и «Statistica 6.0». Проверка нормальности распределения осуществлялась с помощью теста Колмогорова - Спирина. Показатель достоверности оценивали по Стьюденту. Различия оценивались как достоверные при вероятности 95\% $(p<0,05)$ и выше.

Результаты и их обсуждение. Качество жизни населения с помощью опросника SF-36 оценивалось в шести районах Саратовской области с различным уровнем заболеваемости туберкулезом в период прохождения флюорографического обследования (табл. 1). Как следует из табл. 1, количество лиц, включенных в исследование, и их возраст в различных районах были статистически сопоставимыми, что обеспечивает корректность статистической обработки полученных результатов.
В целом можно отметить, что при снижении качества жизни населения увеличивается заболеваемость туберкулезом. Так, максимальный уровень заболеваемости туберкулезом в 2012 г. был зарегистрирован в Воскресенском районе и составил 82,6 на 100 тыс. населения, а минимальный - в Аркадакском (23,7 на 100 тыс. населения). Таким образом, заболеваемость в Воскресенском районе оказалась практически в 3,5 раза выше, чем в Аркадакском. В то же время на фоне низкой заболеваемости у населения Аркадакского района регистрировались более высокие значения показателя качества жизни по шкалам опросника SF-36. Наиболее выраженные различия при высокой и низкой заболеваемости туберкулезом отмечались по таким шкалам опросника SF-36, как ролевое эмоциональное функционирование (RE), социальное функционирование (SF), общее состояние здоровья $(\mathrm{GH})$, психическое здоровье (МН). В Аркадакском районе при уровне заболеваемости 23,7 на 100 тыс. населения: $\mathrm{GH}-(38,7 \pm 1,4)$ ед., SF - $(40,3 \pm 3,2)$ ед., $\mathrm{RE}-(35,1 \pm 1,2)$ ед., MH - $(46,4 \pm 0,9)$ ед., в то время как в Воскресенском - $\mathrm{GH}-(21,2 \pm 1,8)$ ед., $\mathrm{SF}-(23,8 \pm 1,2)$ ед., RE - $(18,1 \pm 1,6)$ ед., $\mathrm{MH}-$ $(30,2 \pm 1,4)$ ед. $(p<0,05)$. Значения по другим шкалам по мере роста заболеваемости в районах области также снижались. Так, в Аркадакском районе значения по шкале физического функционирования (PF) были равны $(42,8 \pm 2,6)$ ед., а в Воскресенском районе снижались до $(37,6 \pm 3,3)$ ед. $(p>0,05)$. Различия по шкале ролевого фиизиеского функционирования (PF) не превышали 9,1\%, болевых ощущений (BP)$9,5 \%$, жизнеспособности (VT) - 9,4\% ( $p>0,05)$.

Суммируя представленные в табл. 1 данные, можно констатировать, что между снижением качества жизни населения на анализируемой территории за один год наблюдения и показателем заболеваемости туберкулезом имеется определенная зависимость. В настоящем исследовании нами были установлены численные значения имеющейся взаимосвязи в виде регрессионной зависимости. Данная зависимость позволяет вычислить прогнозируемую заболеваемость туберкулезом в конце второго года наблюдения, если в предыдущем году качество жизни изменилось на $x_{1}$. В данном случае $x_{1}$ опреде-

Т а блица 1

Соотношение уровня заболеваемости туберкулезом с показателями качества жизни опросника SF-36

\begin{tabular}{|c|c|c|c|c|c|c|c|c|c|c|c|}
\hline \multirow[b]{2}{*}{$\begin{array}{c}\text { Районы } \\
\text { Саратовской } \\
\text { области }\end{array}$} & \multirow[b]{2}{*}{$\begin{array}{l}\text { Кол- } \\
\text { во, } n\end{array}$} & \multirow[b]{2}{*}{$\begin{array}{c}\text { Возраст, } \\
\text { лет }\end{array}$} & \multirow{2}{*}{$\begin{array}{c}\text { Уровень } \\
\text { заболева- } \\
\text { емости на } \\
100 \text { тыс. } \\
\text { населе- } \\
\text { ния, } 2012\end{array}$} & \multicolumn{8}{|c|}{ Шкалы опросника SF-36 } \\
\hline & & & & PF & RP & BP & $\mathrm{GH}$ & VT & SF & RE & $\mathrm{MH}$ \\
\hline $\begin{array}{l}\text { Воскресен- } \\
\text { ский }\end{array}$ & 437 & $44,6 \pm 5,9$ & 82,6 & $37,6 \pm 3,3$ & $41,7 \pm 2,1$ & $40,3 \pm 1,8$ & $21,2 \pm 1,8$ & $48,6 \pm 2,1$ & $23,8 \pm 1,2$ & $18,1 \pm 1,6$ & $30,2 \pm 1,4$ \\
\hline Ершовский & 389 & $47,1 \pm 4,8$ & 73,9 & $40,3 \pm 2,8$ & $40,6 \pm 1,6$ & $39,9 \pm 2,3$ & $24,6 \pm 1,8$ & $46,6 \pm 1,8$ & $25,6 \pm 1,8$ & $22,6 \pm 0,8$ & $31,7 \pm 1,4$ \\
\hline Алгайский & 401 & $45,5 \pm 6,4$ & 59,9 & $42,2 \pm 1,6$ & $41,5 \pm 2,1$ & $41,6 \pm 1,7$ & $27,4 \pm 1,6$ & $26,2 \pm 2,8^{*}$ & $30,7 \pm 2,2$ & $24,4 \pm 1,2$ & $34,8 \pm 1,6$ \\
\hline Ивантеевский & 416 & $42,9 \pm 8,1$ & 40,3 & $24,6 \pm 1,7^{*}$ & $44,6 \pm 3,1$ & $40,7 \pm 1,6$ & $31,7 \pm 2,1$ & $52,6 \pm 1,4$ & $38,4 \pm 1,6^{*}$ & $27,2 \pm 1,6^{*}$ & $38,2 \pm 2,4$ \\
\hline Татищевский & 377 & $46,1 \pm 4,9$ & 31,6 & $41,9 \pm 2,8$ & $44,8 \pm 2,1$ & $37,8 \pm 2,4$ & $36,1 \pm 1,2^{*}$ & $54,1 \pm 1,6$ & $40,3 \pm 2,0^{*}$ & $30,9 \pm 1,6^{*}$ & $43,7 \pm 1,0$ * \\
\hline Аркадакский & 431 & $46,5 \pm 3,8$ & 23,7 & $42,8 \pm 2,6$ & $45,4 \pm 1,9$ & $38,2 \pm 1,6$ & $38,7 \pm 1,4^{*}$ & $51,7 \pm 2,8$ & $40,3 \pm 3,2^{*}$ & $35,1 \pm 1,2^{*}$ & $46,4 \pm 0,9^{*}$ \\
\hline
\end{tabular}

*Достоверность различий с Воскресенским районом $(p<0,05)$. 
ляется как качество жизни в начале года $P_{1}$ минус качество жизни в конце года $P_{2}$, т.е. $x_{1}=P_{1}-P_{2}$. Учитывая, что при оценке качества жизни необходимо оценивать все ее составляющие по восьми шкалам опросника SF-36, суммарное изменение качества жизни в шести районах Саратовской области будет вычисляться по формуле:

$$
x_{1}=\sum_{1}^{n} P_{i}-\sum_{1}^{n} P_{j},
$$

где $P_{i}$ - значения по шкалам опросника SF-36 в начале предыдущего года; $P_{-}$- в начале последующего; $n-$ количество районов в Саратовской области, где проходило обследование; $i, j$ - количество шкал опросника.

На втором этапе для нахождения коэффициента линейной регрессии мы определяем прирост заболеваемости туберкулезом к концу второго года наблюдения при известном изменении качества жизни в предыдущем в процентах по фрормуле:

$$
\left(100-\frac{\sum_{1}^{n} P_{i}}{\sum_{1}^{n} P_{j}},\right.
$$

где $R_{i}$ - число случаев туберкулеза на 100 тыс. в предыдущем году; $R_{j}$ - в последующем; $n-$ количество районов в Саратовской области.

На заключительном этапе вычислений мы находим отношение, показывающее на сколько процентов изменится количество заболевших туберкулезом к концу второго года наблюдения при изменении суммарного качества жизни населения в предыдущем году на одну условную единицу опросника SF-36.

Проведенные расчеты по результатам анализа показателей качества жизни у 2451 человека из 6 районов показали, что снижение суммарного показателя качества жизни населения на 1 ед. увеличивает заболеваемость туберкулезом на анализируемой территории на 0,53\%. При улучшении показателя качества жизни наблюдается обратная тенденция.

Для оценки надежности выявленных взаимосвязей между изменением качества жизни населения и динамикой заболеваемости туберкулезом нами в период с 2011 по 2013 г. в других шести районах Саратовской области производился мониторинг качества жизни, а полученные данные сопоставлялись с изменением заболеваемости (табл. 2). При детальном анализе полученных данных можно отметить, что во всех случаях снижение качества жизни населения в течение года сопровождалось в следующем году ростом заболеваемости туберкулезом, а повышение качества жизни - улучшением эпидемиологической обстановки. Так, в Питерском районе в 2011 г. заболеваемость туберкулезом составила 43,9 на 100 тыс. населения. В этом же году качество жизни населения повысилось на 45,2 ед. При данных условиях согласно выполненным расчетам в 2012 г. прогнозировалось снижение заболеваемости туберкулезом на $24,1 \%$, или до 36,7 на 100 тыс. населения в относительных значениях. По данным официальной статистики Минздрава Саратовской области, заболеваемость в Питерском районе оказалась еще ниже и составила 33,9 на 100 тыс. населения, т.е. расхождения в количественном выражении между прогнозом и реальными цифрами не превысили 7,6\%. Аналогичные данные были получены при прогнозировании ухудшения эпидемиологической обстановки по туберкулезу в Ртищевском районе в 2013 г. В 2012 г. заболеваемость туберкулезом составила 34,5 на 100 тыс. населения, по данным анкетирования качество жизни населения на данной территории снизилось за один год на 56,6 ед., что, согласно разработанной методики, прогнозирует повышение заболеваемости туберкулезом в 2013 г. на 30\% - до 48,6 на 100 тыс. населения в относительных значениях. Реальная заболеваемость туберкулезом в Ртищевском районе в 2013 г. составила 50,6 на 100 тыс. населения, что на 4,0\% выше прогноза. Суммируя полученные данные, можно констатировать, что изменения ка-

Таблица 2

Соотношения изменений в качестве жизни населения с динамикой эпидемиологической обстановки по туберкулезу

\begin{tabular}{|c|c|c|c|c|c|c|c|c|c|c|c|c|c|}
\hline \multirow{4}{*}{$\begin{array}{c}\text { Районы } \\
\text { Саратовской } \\
\text { области }\end{array}$} & \multirow{4}{*}{$\begin{array}{l}\text { Кол- } \\
\text { во, } n\end{array}$} & \multicolumn{12}{|c|}{ Период наблюдения } \\
\hline & & \multicolumn{4}{|c|}{2011 г. } & \multicolumn{4}{|c|}{2012 г. } & \multicolumn{4}{|c|}{2013 г. } \\
\hline & & \multirow{2}{*}{ 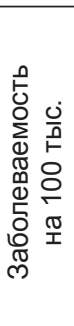 } & \multirow{2}{*}{ 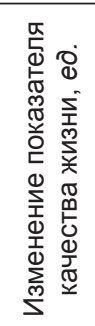 } & \multicolumn{2}{|c|}{$\begin{array}{c}\text { Прогноз заболе- } \\
\text { ваемости } \\
\text { на } 2012 \text { г. }\end{array}$} & \multirow{2}{*}{ 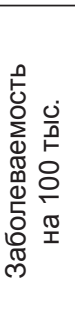 } & \multirow{2}{*}{ 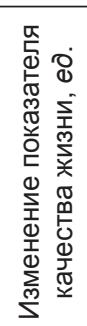 } & \multicolumn{2}{|c|}{$\begin{array}{c}\text { Прогноз заболе- } \\
\text { ваемости } \\
\text { на } 2013 \text { г. } \\
\end{array}$} & \multirow{2}{*}{ 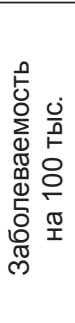 } & \multirow{2}{*}{ 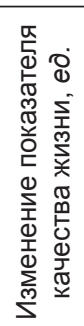 } & \multicolumn{2}{|c|}{$\begin{array}{c}\text { Прогноз забо- } \\
\text { леваемости } \\
\text { на } 2014 \text { г. }\end{array}$} \\
\hline & & & & 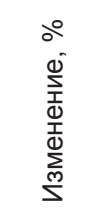 & 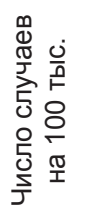 & & & 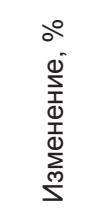 & 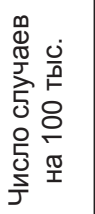 & & & 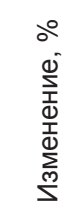 & 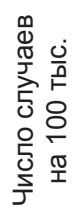 \\
\hline Питерский & 410 & 43,9 & 45,2 & $-24,1$ & 36,7 & 33,9 & 47,1 & $-15,1$ & 25,1 & 28,7 & $-54,7$ & 29,4 & 39,6 \\
\hline Пугачевский & 390 & 63,8 & 30,1 & $-16,2$ & 53,8 & 57,4 & 88,6 & $-47,4$ & 30,4 & 38,1 & $-47,7$ & 16,7 & 44,8 \\
\hline Ртищевский & 431 & 27,6 & $-20,9$ & 11,1 & 30,6 & 34,5 & $-56,6$ & 30,0 & 48,6 & 50,6 & $-22,2$ & 11,8 & 56,6 \\
\hline Дергачевский & 386 & 52,4 & 34,1 & $-18,1$ & 43,7 & 39,0 & $-84,9$ & 45,0 & 60,2 & 74,3 & $-16,7$ & 8,9 & 80,3 \\
\hline Романовский & 392 & 25,6 & 37,7 & $-20,0$ & 20,6 & 19,0 & 41,8 & $-22,2$ & 15,7 & 19,4 & $-91,6$ & 48,6 & 31,6 \\
\hline Турковский & 401 & 17,1 & 68,3 & $-26,2$ & 11,2 & 13,0 & 25,6 & $-13,6$ & 14,3 & 16,4 & $-64,7$ & 34,3 & 24,2 \\
\hline
\end{tabular}
в районах Саратовской области за период с 2011 по 2013 г. 
чества жизни на конкретной территории можно рассматривать в качестве опережающего индикатора при определении эпидемиологической обстановки по туберкулезу на ближайший период по параметру заболеваемости.

\section{Выводы:}

Мониторинг качества жизни населения с помощью опросника SF-36 может выступать в качестве опережающего индикатора при прогнозировании эпидемиологической обстановки по туберкулезу на конкретной территории.

Результаты исследования показали, что на каждую условную единицу снижения суммарного показателя качества жизни, по данным опросника SF-36, у 2451 человека, проживающего в шести районах Саратовской области, в текущем году прогнозируется рост заболеваемости туберкулезом на 0,53\% в последующем.

Расхождения между прогнозируемой и реальной заболеваемостью туберкулезом на конкретной территории Саратовской области по разработанной методике варьировали в пределах 6,7-25,3\% и в среднем составили 15,8\%, что позволяет рекомендовать данный метод для применения в практическом здравоохранении.

\section{ЛИТЕРАТУРА}

1. Баринбойм, О.Н. Медико-экономические возможности оптимизации лечения туберкулеза у больных с лекарственной устойчивостью: дис. ... канд. мед. наук / Баринбойм Ольга Николаевна. - М., 2009. - 143 с.

2. Белиловский, Е.M. Заболеваемость туберкулезом в Российской Федерации / Е.М. Белиловский, С.Е. Борисов, И.М. Сон, О.Б. Нечаева // Туберкулез в Российской Федерации в 2011 г. Аналитический обзор статистических показателей, используемых в Российской Федерации и в мире. - М., 2013. - С.27-38.

3. Гнездилова, Е.В. Качество жизни у инвалидов по туберкулезу легких / Е.В. Гнездилова // Восьмой Национальный конгресс по болезням органов дыхания: сб. резюме. - М., 1998. - С.481.

4. Гурылева, М.Э. Качество жизни больных туберкулезом на санаторном этапе лечения / М.Э. Гурылева, Л.А. Горбунова, О.В. Ловачева, 3.Х. Корнилова // Проблемы туберкулеза и болезней легких. - 2005. № 7. - C.17-22.

5. Докторова, Н.П. Клинико-экономическая эффективность лечения молодых больных инфильтративным деструктивным туберкулезом легких с разной степенью социальной адаптации: дис. ... канд. мед. наук / Докторова Наталья Петровна. - М., 2007. - 152 с.

6. Казимирова, Н.Е. Эколого-эпидемиологическая характеристика лекарственно-устойчивых форм возбудителя туберкулеза / Н.Е. Казимирова, Л.Е. Паролина // Вестник Российской военно-медицинской академии. 2008. — № 2(22), ч. 2. - С.408-409.

7. Морозова, Т.И. Критерии оценки эффективности химиотерапии в противотуберкулезном стационаре / Т.И. Морозова, Л.Е. Паролина, Н.П. Докторова // Проблемы туберкулеза и болезней легких. — 2007. № $6 .-$ C.13-15

8. Морозова, Т.И. Туберкулез легких: социальные проблемы / Т.И. Морозова, Л.Е. Паролина, В.И. Завалев. Саратов: СГМУ, 2003. - 150 с

9. Пьянзова, Т.В. Качество жизни больных с впервые выявленным туберкулезом легких, получающих противотуберкулезную терапию на стационарном этапе
/ Т.В. Пьянзова, Н.В. Лузина, О.А. Беликова [и др.] // Туберкулез и болезни легких. - 2011. - № 5. C.130-131.

10. Суховская, О.А. Использование общих и специальных опросников изучения качества жизни в пульмонологии / О.А. Суховская // Десятый Национальный конгресс по болезням органов дыхания: сб. резюме. - СПб., 2000. - C.187.

\section{REFERENCES}

1. Barinboim, O.N. Mediko-ekonomicheskie vozmozhnosti optimizacii lecheniya tuberkuleza u bol'nyh s lekarstvennoi ustoichivost'yu: dis. ... kand. med. nauk [Clinical and economic opportunities to optimize the treatment of tuberculosis in patients with drug-resistant] / Barinboim Ol'ga Nikolaevna. - M., 2009. - $143 \mathrm{~s}$.

2. Belilovskii, E.M. Zabolevaemost' tuberkulezom v Rossiiskoi Federacii [The incidence of tuberculosis in the Russian Federation] / E.M. Belilovskii, S.E. Borisov, I.M. Son, O.B. Nechaeva // Tuberkulez v Rossiiskoi Federacii v 2011 g. Analiticheskii obzor statisticheskih pokazatelei, ispol'zuemyh v Rossiiskoi Federacii i v mire [Tuberculosis in the Russian Federation, 2011. Analytical review of the statistical indicators used in the Russian Federation for tuberculosis]. - M., 2013. - S.27-38.

3. Gnezdilova, E.V. Kachestvo zhizni u invalidov po tuberkulezu legkih [Quality of life of persons with disabilities to pulmonary tuberculosis] / E.V. Gnezdilova // Vos'moi Nacional'nyi kongress po boleznyam organov dyhaniya: sb. rezyume [8 National Congress on Respiratory Diseases: Proceedings resume]. - M., 1998. - S.481.

4. Guryleva, M.E. Kachestvo zhizni bol'nyh tuberkulezom na sanatornom etape lecheniya [Quality of life of patients with tuberculosis on sanatorium stage of treatment] / M.E. Guryleva, L.A. Gorbunova, O.V. Lovacheva, Z.H. Kornilova // Problemy tuberkuleza i boleznei legkih [Problems of Tuberculosis and Lung Disease]. — 2005. № 7 . $-\mathrm{S} .17-22$.

5. Doktorova, N.P. Kliniko-ekonomicheskaya effektivnost' lecheniya molodyh bol'nyh infil'trativnym destruktivnym tuberkulezom legkih s raznoi stepen'yu social'noi adaptacii: dis. ... kand. med. nauk [Clinical and economic effectiveness of treatment of young patients with infiltrative pulmonary tuberculosis with lung destruction and different level of their social adaptation] / Doktorova Natal'ya Petrovna. - M., 2007. - $152 \mathrm{~s}$.

6. Kazimirova, N.E. Ekologo-epidemiologicheskaya harakteristika lekarstvenno-ustoichivyh form vozbuditelya tuberkuleza [Ecological and epidemiological characteristics Mycobacterium tuberculosis of drug-resistant] / N.E. Kazimirova, L.E. Parolina // Vestnik Rossiiskoi voenno-medicinskoi akademii [Bulletin of the Russian Academy of Military Medicine]. — 2008. - № 2(22), ch. 2. - S.408-409.

7. Morozova, T.I. Kriterii ocenki effektivnosti himioterapii v protivotuberkuleznom stacionare [Criteria for assessing the effectiveness of chemotherapy in a tuberculosis hospital] / T.I. Morozova, L.E. Parolina, N.P. Doktorova // Problemy tuberkuleza i boleznei legkih [Problems of Tuberculosis and Lung Disease]. — 2007. — № 6. - S.13-15.

8. Morozova, T.I. Tuberkulez legkih: social'nye problemy [Pulmonary tuberculosis: social problems] / T.I. Morozova, L.E. Parolina, V.I. Zavalev. — Saratov: SGMU, 2003. $150 \mathrm{~s}$.

9. P'yanzova, T.V. Kachestvo zhizni bol'nyh s vpervye vyyavlennym tuberkulezom legkih, poluchayuschih protivotuberkuleznuyu terapiyu na stacionarnom etape [Quality of life in patients newly diagnosed with pulmonary tuberculosis receiving TB treatment at a stationary 
stage] / T.V. P'yanzova, N.V. Luzina, O.A. Belikova [i dr.] // Tuberkulez i bolezni legkih [Tuberculosis and Lung Disease]. - 2011. — № 5. - S.130-131.

10. Suhovskaya, O.A. Ispol'zovanie obschih i special'nyh oprosnikov izucheniya kachestva zhizni $v$ pul'monologii
[The use of questionnaires of general and special study of quality of life in pulmonology] / O.A. Suhovskaya // Desyatyi Nacional'nyi kongress po boleznyam organov dyhaniya: sb. rezyume [10 National Congress on Respiratory Diseases: Proceedings resume]. — SPb., 2000. - S.187.

\title{
РЕЗУЛЬТАТЫ ТОТАЛЬНОГО РАЗОБЩЕНИЯ ГАСТРОЭЗОФАГЕАЛЬНОГО КОЛЛЕКТОРА У БОЛЬНЫХ С СИНДРОМОМ ПОРТАЛЬНОЙ ГИПЕРТЕНЗИИ
}

\author{
ФЕРУЗ ГАФУРОВИЧ НАЗЫРОВ, докт. меД. наук, проф., директор Республиканского специализированного центра \\ хирургии им. акад. В.Вахидова, Ташкент, Узбекистан, тел. 8-371-233-49-09, e-mail: cs75@mail.ru \\ АНДРЕЙ ВАСИЛЬЕВИЧ ДЕВЯТОВ, докТ. меД. наук, проф., гЛ. научный сотрудник отделения хирургии портальной \\ гипертензии и панкреатодуоденальной зоны Республиканского специализированного центра хирургии \\ им. акад. В.Вахидова, Ташкент, Узбекистан, тел. 8-371-277-06-17, e-mail: avdevyatov1777@gmail.com \\ АЗАМ ХАСАНОВИЧ БАБАДЖАНОВ, канд. мед. наук, старший научный сотрудник отделения хирургии портальной \\ гипертензии и панкреатодуоденальной зоны Республиканского специализированного центра хирургии \\ им. акад. В. Вахидова, Ташкент, Узбекистан, тел. 8-371-277-06-17, e-mail: azam747@mail.ru \\ Жасур Давранович Жамилов, врач-ординатор отделения хирургии портальной гипертензии \\ и панкреатодуоденальной зоны Республиканского специализированного центра хирургии \\ им. акад. В. Вахидова, Ташкент, Узбекистан, тел. 8-371-277-06-17, e-mail: jasurdavronovich@gmail.com
}

Реферат. Цель исследования - изучить отдаленные результаты модифицированной методики тотального разобщения гастроэзофагеального коллектора у больных с синдромом портальной гипертензии. Материал и методы. К настоящему времени модифицированный вариант операции выполнен 73 больным с синдромом портальной гипертензии (ПГ). У 36 больных причиной ПГ явился цирроз печени (ЦП), у 30 больных диагностирована внепеченочная форма ПГ, еще у 8 больных установлена смешанная форма ПГ. Возраст больных колебался от 13 до 65 лет, средний показатель при этом составил $(31,6 \pm 1,7)$ года. По полу больные распределились следующим образом: мужчин - 44, женщин - 29. В 53 случаях больные госпитализированы в плановом порядке, а 20 пациентов доставлены в экстренном порядке с клиникой гастроэзофагеального кровотечения. Результаты и их обсуждение. Отдаленный период прослежен у 46 больных с первичной методикой и у 66 пациентов с модифицированной техникой тотального разобщения гастроэзофагеального коллектора (ТРГЭК). Рецидив кровотечений отмечен у $15,2 \%$ больных, причем в $6,5 \%$ на фоне анастомозита. Явления гастростаза выявлены у 3 из 46 пациентов. Явления печеночной недостаточности развились у 23,9\% больных. На фоне указанных осложнений умерло 15,2\% пациентов. В группе с модифицированной методикой кровотечение отмечено в $6,0 \%$ случаев. Кровотечение из эрозий в зоне лигатурной транссекции было остановлено консервативно. Летальность в отдаленные сроки наблюдения составила 7,6\% (5 пациентов). Общая летальность за ближайший и отдаленный периоды в группах сравнения составила 22,2\% и 16,4\% соответственно. Заключение. Прерывание гастроэзофагеального венозного коллектора путем лигатурной транссекции на синтетическом протезе, в отличие от ранее предложенных методов ТРГЭК, позволяет не только облегчить техническое выполнение операции, но и обеспечивает профилактику ранних послеоперационных осложнений, связанных с травматичностью предыдущих методик, а также грубых функциональных нарушений желудка в отдаленном периоде.

Ключевые слова: цирроз печени, портальная гипертензия, разобщающие операции, метод лигатурный транссекции, кровотечение из ВРВПЖ.

\section{RESULT OF TOTAL DISSOCIATION OF GASTROESOPHAGEAL COLLECTOR IN PATIENTS WITH PORTAL HYPERTENSION}

FERUZ G. NAZYROV, Doctor of Medical Science, Professor, Director of Republican Specialized Center of Surgery of named after acad. V.Vahidov, Tashkent, Uzbekistan, tel. 8-371-233-49-09, e-mail: cs75@mail.ru ANDREY V. DEVYATOV, Doctor of Medical Science, Professor, chief researcher of the Department of surgery of portal hypertension and pancreatoduodenal zone of Republican Specialized Center of Surgery of named after acad. V.Vahidov, Tashkent, Uzbekistan, tel. 8-371-277-06-17, e-mail: avdevyatov1777@gmail.com AZAM KH. BABADZHANOV, Candidate of Medical Science, senior research fellow of the Department of surgery of portal hypertension and pancreatoduodenal zone of Republican Specialized Center of Surgery of named after acad. V.Vahidov, Tashkent, Uzbekistan, tel.8-371-277-06-17, e-mail: azam747@mail.ru

ZHASUR D. ZHAMILOV, surgeon of the Department of surgery of portal hypertension and pancreatoduodenal zone of Republican Specialized Center of Surgery of named after acad. V.Vahidov, Tashkent, Uzbekistan, tel. 8-371-277-06-17, e-mail: jasurdavronovich@gmail.com

Abstract. Aim. To study long-term results of the modified technique of total dissociation of gastroesophageal collector (TDGEC) in patients with portal hypertension. Material and methods. A modified version of the operation carried out to 73 patients with the $\mathrm{PH}$ syndrome. In 36 patients the cause of $\mathrm{PH}$ was liver cirrhosis, 30 patients diagnosed 
with extrahepatic form of $\mathrm{PH}, 8$ patients established a mixed form of $\mathrm{PH}$. The age of patients ranged from 13 to 65 years, thus the mean was $(31,6 \pm 1,7)$ years. Patients were distributed by gender as follows: men -44 , women -29 . 53 patients hospitalized in a planned order, and 20 patients delivered urgently with the clinic of gastroesophageal bleeding. Results and discussion. Remote period was followed up in 46 patients with primary procedure and 66 patients with a modified technique of TDGEC. Rebleeding was observed in $15,2 \%$ of patients, and among them $6,5 \%$ were on anastomositis. Gastrostasis phenomenon was observed in 3 of 46 patients. The phenomenon of liver failure occurred in $23,9 \%$ of patients. On a background of these complications $15,2 \%$ patients died. In the group with a modified procedure bleeding observed in $6,0 \%$ of cases. Bleedings from erosion in the area of ligature transection were stopped conservatively. Mortality in long-term period of observation was 7,6\% (5 patients). Overall mortality for the near and distant periods in the comparison groups was $22,2 \%$ and $16,4 \%$, respectively. Conclusion. Interruption of gastroesophageal venous reservoir by ligature transection on synthetic prosthesis, unlike previously proposed methods of TDGEC not only alleviate technique of operation, but also provides prevention of early postoperative complications associated with traumatism of previous methods, as well as gross functional disorders of the stomach in the long term.

Key words: liver cirrhosis, portal hypertension, dissociative operations, technique of ligature transection, bleeding from esophageal varices.

$\mathrm{C}$ реди всех желудочно-кишечных геморрагий кровотечения из варикозно-расширенных вен пищевода и желудка (ВРВПЖ) у больных циррозом печени (ЦП) с портальной гипертензией (ПГ) выделяются особой тяжестью клинических проявлений, серьезными осложнениями и высокой вероятностью летального исхода. При противопоказаниях к радикальному лечению ЦП - трансплантации печени - основным направлением хирургического лечения этой категории пациентов является реконструкция сосудов портального бассейна $[6,7,9]$. Однако для портосистемного шунтирования существуют определенные показания и противопоказания, они составляют большую группу больных, у которых по ряду причин выполнение этого вмешательства невозможно и соответственно требуется реализация других видов хирургического лечения, среди которых методом выбора остается операция портоазигального разобщения. Основными преимуществами данной операции являются поддержание постоянной портальной перфузии печени, отсутствие развития постшунтовой энцефалопатии и более широкие возможности остановки пищеводных кровотечений при выполнении ургентной хирургии [4, 5, 8].

Вместе с тем стратегическим недостатком экстренных и плановых разобщающих операций является отсутствие устойчивых отдаленных результатов. Так, спустя год, и даже менее, наблюдается активное восстановление варикозно-расширенных вен с нарастанием угрозы рецидива кровотечения $[1,2,3]$.

На сегодняшний день разработанные в РСЦХ им. акад. В. Вахидова и внедренные в практику оригинальные технологии тотального разобщения гастроэзофагеального коллектора (ТРГЭК), обладая высокой гемостатической эфффективностью, направлены на ликвидацию основного недостатка известных операций. В этой связи представляет интерес анализ отдаленных результатов этих операций с оценкой эффективности профилактики пищеводных кровотечений и выживаемости больных.

Первично была разработана оригинальная методика ТРГЭК с лигатурной транссекцией субкардиального отдела желудка с последующим формированием гастрогастрального обходного анастомоза (в период с 1998 по 2007 г. такие операции были выполнены у 63 больных). Этапы операции включали мобилизацию желудка по большой и малой кривизне; транссекцию желудка лигатурным способом на уровне субкардиального отдела; формирование гастро-гастрального обходного анастомоза поверх лигатуры. Данный вид операции имеет два варианта исполнения: лигатурный и аппаратный. По мере накопления опыта мы пришли к выводу, что лигатурный способ является предпочтительным. Анализ отдаленных (от 3 мес до 10 лет) результатов выполненных разобщающих операций был проведен у 46 пациентов. Рецидив кровотечений отмечен у 10,9\% больных, причем в 6,5\% на фроне анастомозита. Явления гастростаза выявлены у 5 из 46 пациентов. При этом на контрольной эндоскопии уже в сроки через 3 мес после операции отмечена реканализация желудка в зоне лигатурной транссекции с формированием двух путей для пассажа пищи реканализированного естественного и через наложенный гастро-гастральный анастомоз. На фоне осложнений умерло 19,6\% пациентов. Указанные фракты позволили предположить о возможности выполнения лигатурной транссекции кардиального отдела желудка на каркасной основе с сохранением естественного пути для пассажа пищи без наложения гастро-гастрального анастомоза.

Цель исследования - изучить отдаленные результаты модифицированной методики тотального разобщения гастроэзофагеального коллектора у больных с синдромом портальной гипертензии.

Материал и методы. В 2008 г. модифицированная методика тотального разобщения гастроэзофагеального коллектора (ТРГЭК) (операция Ф.Г. Назырова) была внедрена в клиническую практику. Отличительной особенностью нового метода является разобщение за счет применения внутрипросветного протеза, устанавливаемого во время операции.

Способ осуществляется в следующей последовательности: доступ - верхнесрединная лапаротомия. Производится проксимальная деваскуляризация желудка вплоть до абдоминального отдела пищевода по малой и большой кривизне органа. 


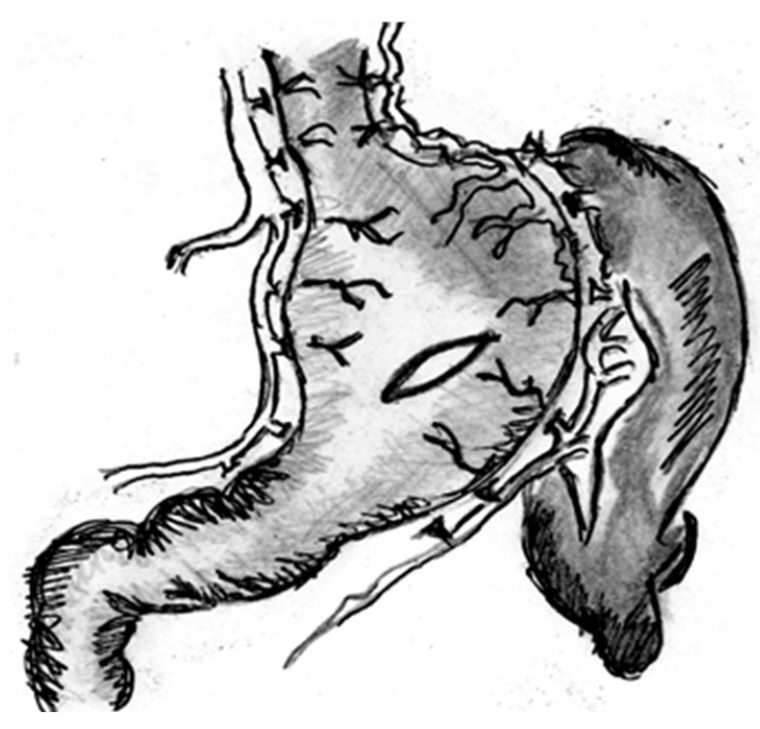

Рис. 1. Этап деваскуляризации желудка и абдоминального отдела пищевода с гастротомией

При этом органный кровоток сохраняется по правой желудочной и двум желудочно-сальниковым артериям. Левая желудочная артерия перевязывается и пересекается экстраорганно. Также перевязываются и пересекаются все короткие сосуды желудка (рис. 1). Затем в средней части тела желудка по передней стенке производится поперечная гастротомия и через образованное отверстие в просвет желудка вводится ПВХ-протез и располагается в просвете субкардиального отдела желудка. Над протезом, введенным в просвет желудка, поверх серозной оболочки накладывается лигатура, которая разделяет желудок на верхнюю (1/3) и нижнюю (2/3) части. Лигатуру затягивают над протезом, в это время протез фиксируется пальцем хирурга, введенным в ее просвет. Таким образом, контролируется расположение протеза и натяжение лигатуры. Затем накладывается повторная лигатура над первой.

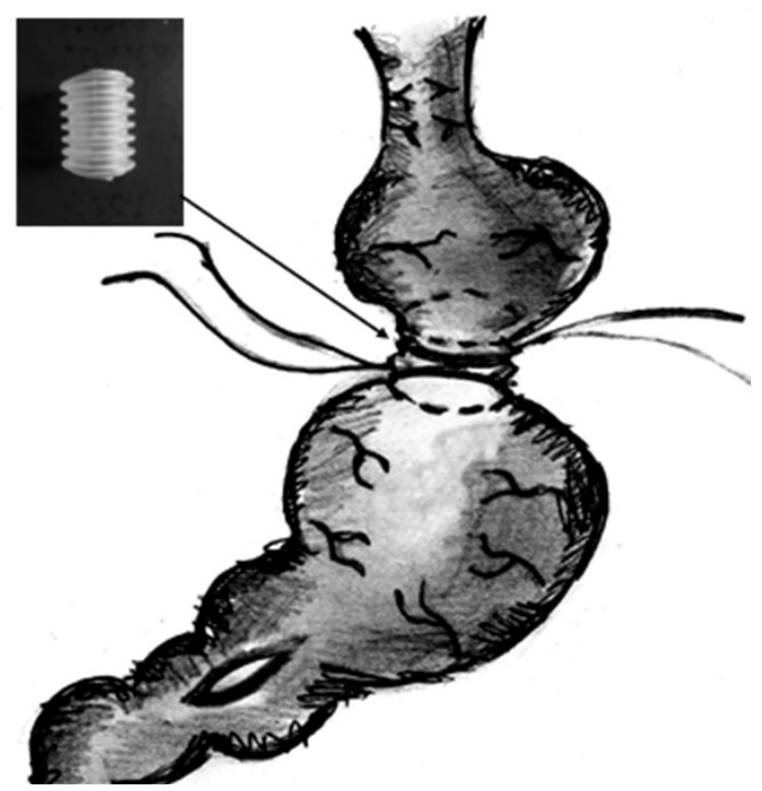

Рис. 2. Этап лигатурной транссекции на протезе-кольце
Гофрированность протеза обеспечивает фиксацию лигатур, препятствуя их смещению (рис. 2). Через протез проводится назогастральный зонд с целью декомпрессии в послеоперационном периоде. Гастротомное отверстие ушивается двурядным швом. Над лигатурой желудка также накладывается ряд серо-серозных швов. Дополнительно выполняется пилоропластика. Через 1-1,5 мес проводится эндоскопическое исследование, и из просвета желудка протез удаляется. К этому моменту наложенные поверх него лигатуры прорезываются в просвет желудка и при этом разобщается венозный коллектор.

К настоящему времени операция выполнена 73 больным с синдромом ПГ. У 36 больных причиной ПГ явился ЦП, у 30 больных диагностирована внепеченочная форма ПГ, еще у 8 больных установлена смешанная форма ПГ. Возраст больных колебался от 13 до 65 лет, средний показатель при этом составил $(31,6 \pm 1,7)$ года. По полу больные распределились следующим образом: мужчин 44, женщин - 29. В 53 случаях больные госпитализированы в плановом порядке, а 20 пациентов доставлены в экстренном порядке с клиникой гастроэзофагеального кровотечения. Больным проводились как общие (общеклинические и биохимические анализы крови, ЭКГ, рентгеноскопия грудной клетки), так и специальные (радиоизотопное исследование печени, ангиография) методы исследования.

Степень варикозного расширения вен пищевода оценена по классификации А.Г. Шерцингера (1986). При этом у всех больных выявлена вторая степень ВРВПЖ. Все больные в анамнезе перенесли пищеводно-желудочные кровотечения, причем 40 $(54,8 \%)$ из них многократно. В 13 случаях больным дополнительно произведена спленэктомия. В 8 случаях больные в анамнезе уже перенесли спленэктомию. У $8(11,0 \%)$ пациентов на момент поступления выявлен сахарный диабет.

Результаты и их обсуждение. В ближайшем послеоперационном периоде наиболее частым осложнением ранее разработанных методик разобщения являлась недостаточность швов кардиофундального анастомоза (11,7\% при плановых операциях и $21,1 \%$ при экстренных вмешательствах). В отличие от них предложенный новый вариант осуществляется через небольшое гастротомное отверстие, в связи с чем подобных осложнений не наблюдалось. С другой стороны, еще у $11,1 \%$ больных отмечено развитие анастомозитов, которые значительно повышали риск развития кровотечения из зоны анастомоза. Явления печеночной недостаточности и энцефалопатии отмечены у 15 (23,8\%) пациентов. Общая летальность в ближайший период составила 11,1\% (7 больных).

Модифицированная лигатурная транссекция позволила полностью нивелировать риск недостаточности анастомоза и сократить частоту печеночной недостаточности и летальности (табл. 1). Рентгеноконтрастное исследование на 10-е сут после операции показало, что протез свободно проходим, нарушения эвакуаторной 
Сравнительная частота ранних послеоперационных осложнений у больных с ТРГЭК по различным методикам

\begin{tabular}{|l|c|c|}
\hline \multicolumn{1}{|c|}{ Осложнения } & $\begin{array}{c}\text { Оригинальный } \\
\text { метод }\end{array}$ & $\begin{array}{c}\text { Модифициро- } \\
\text { ванный метод }\end{array}$ \\
\hline $\begin{array}{l}\text { Недостаточность ана- } \\
\text { стомоза }\end{array}$ & $7(11,1 \%)$ & - \\
\hline $\begin{array}{l}\text { Некроз стенки желудка } \\
\text { в области лигатурной } \\
\text { транссекции }\end{array}$ & $2(3,2 \%)$ & $2(2,7 \%)$ \\
\hline $\begin{array}{l}\text { Печеночная недостаточ- } \\
\text { ность }\end{array}$ & $15(23,8 \%)$ & $12(16,4 \%)$ \\
\hline Летальность & $7(11,1 \%)$ & $7(9,6 \%)$ \\
\hline
\end{tabular}

фрункций желудка не отмечено. В сроки через месяц после операции на контрольном эндоскопическом исследовании синтетический цилиндр извлекался без технических трудностей. Во всех случаях отмечен регресс варикозно-расширенных вен пищевода.

Проведенный анализ показал, что предрасполагающим фактором к развитию выраженной ишемии стенки желудка с возможностью некроза в области лигирования над протезом является наличие у больных сопутствующего сахарного диабета. Выполнение деваскуляриции желудка с последующей лигатурной транссекцией на фоне диабетической ангиопатии в значительной степени нарушает трофику органа, что и явилось причиной некроза. Следует отметить, что при отсутствии сахарного диабета подобных осложнений мы не наблюдали. В сравнительном аспекте риск очагового некроза желудка в зоне транссекции при наличии сахарного диабета увеличился до 25\% (у 2 из 8 пациентов с сахарным диабетом). Этот факт повлиял на технические аспекты выполнения разобщающих операций у больных с декомпенсированным течением сахарного диабета. В настоящий период операция ограничивается только деваскуляризацией желудка с дополнительной перевязкой левой желудочной вены как основного притока в гастроэзофрагеальный коллектор при ПГ.

Отдаленный период прослежен у 46 больных с первичной методикой и у 66 пациентов с модифицированной техникой ТРГЭК. Рецидив кровотечений отмечен у $15,2 \%$ больных, причем в $6,5 \%$ на фроне анастомозита. Явления гастростаза выявлены у 3 из 46 пациентов. Явления печеночной недостаточности развились у 23,9\% больных. На фоне указанных осложнений умерло 15,2\% пациентов (табл. 2). В группе с модифицированной методикой кровотечение отмечено в 6,0\% случаев. Двоим больным с кровотечением из нижней трети пищевода была успешно выполнена склеротерапия, в последующем рецидивов не отмечалось. Кровотечение из эрозий в зоне лигатурной транссекции были оставновлены консервативно. Летальность в отдаленные сроки наблюдения составила 7,6\% (5 пациентов). Общая летальность за ближайший и отдаленный периоды в группах сравнения составила 22,2 и 16,4\% соответственно.
Сравнительная частота осложнений после ТРГЭК в отдаленный период

\begin{tabular}{|l|c|c|}
\hline \multicolumn{1}{|c|}{ Осложнения } & $\begin{array}{c}\text { Оригинальный } \\
\text { метод }\end{array}$ & $\begin{array}{c}\text { Модифициро- } \\
\text { ванный метод }\end{array}$ \\
\hline $\begin{array}{l}\text { Кровотечение из } \\
\text { ВРВПж }\end{array}$ & $4(8,7 \%)$ & $2(3,0 \%)$ \\
\hline $\begin{array}{l}\text { Кровотечение из зоны } \\
\text { анастомоза (анасто- } \\
\text { мозит) или лигатурной } \\
\text { транссекции }\end{array}$ & $3(6,5 \%)$ & $2(3,0 \%)$ \\
\hline Гастростаз & $3(6,5 \%)$ & $1(1,5 \%)$ \\
\hline $\begin{array}{l}\text { Печеночная недоста- } \\
\text { точность }\end{array}$ & $11(23,9 \%)$ & $8(12,1 \%)$ \\
\hline Летальность & $7(15,2 \%)$ & $5(7,6 \%)$ \\
\hline $\begin{array}{l}\text { Общая летальность в } \\
\text { сроки до 12 мес }\end{array}$ & $14(22,2 \%)$ & $12(16,4 \%)$ \\
\hline
\end{tabular}

Преимуществами модифицированного метода ТРГЭК являются отказ от выполнения кардиофундального анастомоза - сохраняется естественный ход через желудок посредством протеза, фиксированного в кардиальном отделе; сокращение длительности операции за счет выполнения гастротомии без наложения кардиофундального анастомоза; снижение риска развития недостаточности гастротомного отверстия - протяженность гастротомии 3 см, отсутствие кардиофундального анастомоза; широкая интрамуральная зона разобщения вен кардиального отдела желудка - наружное наложение двух лигатур поверх введенного в кардиальный отдел желудка протеза создает протяженность склерозирования до $1 \mathrm{~cm}$.

Анализ выживаемости больных ЦП с ПГ после ТРГЭК показал, что самый низкий показатель выявлен в группах с крупноузловой цирротической трансформацией (медиана выживаемости - 24 мес), у больных с кровотечением в анамнезе (медиана выживаемости - 36 мес) и с декомпенсацией по отечно-асцитическому синдрому до оперативного вмешательства (медиана выживаемости $12 \mathrm{мес})$.

Исследование показало, что выполнение ТРГЭК больным ЦП с высоким портальным давлением повышает риск развития в раннем и позднем послеоперационном периодах геморрагических осложнений и соответственно снижает показатели выживаемости в сроки до 1 года наблюдения до $62 \%$, до 3 лет - до 47\%, что связано не только с гипертензией, но и с вынужденными техническими аспектами операции (лигатурная транссекция и гастро-гастральный анастомоз) на фоне портальной гастропатии.

Выполнение ТРГЭК больным ЦП на фоне отечноасцитического синдрома снижает показатели выживаемости в сроки до 1 года до 48\%, до 3 лет - до $43 \%$, что связано с прогрессированием в отдаленный послеоперационный период двух основных факторов - портальной гипертензии и нарастающей печеночной недостаточности с функциональной декомпенсацией гепатоцитов. 
ТРГЭК больным без сосудистой и отечноасцитической декомпенсации ЦП с ПГ повышает показатели выживаемости в сроки наблюдения до 1 года до 87\%, до 3 лет - до $67 \%$ и в 5 лет - до 58\%. В остальных случаях на фоне прогрессирования указанных осложнений целесообразно выполнение различных вариантов межсистемного сосудистого шунтирования как основного типа вмешательства, направленного на декомпрессию портальной системы.

Выводы. Прерывание гастроэзофагеального венозного коллектора путем лигатурной транссекции на синтетическом протезе, предварительно имплантированного в область субкардии желудка, в отличие от ранее предложенных методов ТРГЭК, позволяет не только облегчить техническое выполнение операции, но и обеспечивает профрилактику ранних послеоперационных осложнений, связанных с травматичностью предыдущих методик, а также грубых функциональных нарушений желудка в отдаленном периоде. Усовершенствованная оригинальная технология ТРГЭК является наиболее перспективным оперативным пособием в условиях ургентной хирургии и при проведении плановых вмешательств у больных с синдромом ПГ, подвергшихся повторному оперативному лечению, или может явиться альтернативным методом портосистемному шунтированию при невозможности выполнения последнего.

\section{ЛИТЕРАТУРА}

1. Варианты технического совершенствования разобщающих операций у больных с портальной гипертензией / А.В. Девятов, А.А. Мансуров, Ш.Х. Хашимов [и др.] // Хирургия Узбекистана. - 2002. - № 1. С.19-22.

2. Тактика ведения больных с внепеченочной портальной гипертензией после прошивания варикознорасширенных вен пищевода и желудка / А.К. Ерамишанцев, Е.А. Киценко, А.М. Нечаенко, Р.С. Григорян // Анналы хирургической гепатологии. - 2002. - Т. 10, № $1 .-$ С.27-32.

3. Мансуров, А.А. Тактические аспекты и новые технологии разобщающих и реконструктивных шунтирующих операций у больных с портальной гипертензией: авторефр. дис. ... д-ра мед. наук / А.А. Мансуров. - Ташкент, 2004. - $115 \mathrm{c}$.

4. External hemorrhage from a portacaval anastomosis in a patient with liver cirrhosis / M. Biyik, R. Ucar, S. Cifci [et al.] // Case Reports Hepatol. - 2014. - Vol. 2014. P.523610—523613.

5. Endoscopic Hemostasis in Acute Esophageal Variceal Bleeding. / A. Cárdenas, A. Baiges, V. Hernandez-Gea, J.C. Garcia-Pagan // Gastroenterol Clin. North Am. 2014. - Vol. 43(4). - P.795-806.

6. Elkrief, L. Prospective Comparison of Spleen and Liver Stiffness by Using Shear-Wave and Transient Elastography for Detection of Portal Hypertension in Cirrhosis / L. Elkrief, P.E. Rautou, M. Ronot [et al.] // Radiology. - 2014. Vol. 28. - P.141210-141214.

7. Fung, J. Management of chronic hepatitis $B$ in severe liver disease / J. Fung, C.L. Lai, M.F. Yuen // World J.
Gastroenterol. — 2014. — Vol. 20(43). - P.1605316061.

8. Stefanescu, H. Noninvasive assessment of portal hypertension in cirrhosis: Liver stiffness and beyond / H. Stefanescu, B. Procopet // World J. Gastroenterol. 2014. - Vol. 20(45). - P.16811-16819.

9. Tandon, $P$. Risk of Bacterial Infection in Patients with Cirrhosis and Acute Variceal Hemorrhage, Based on Child-Pugh Class, and Effects of Antibiotics / P. Tandon, J.G. Abraldes, A. Keough [et al.] // Clin. Gastroenterol. Hepatol. - 2014. - Vol. S1542. P.3565-3569.

\section{REFERENCES}

1. Varianty tehnicheskogo sovershenstvovaniya razobschayuschih operacii u bol'nyh s portal'noi gipertenziei [Technical improvement of options of dissociative operations in patients with portal hypertension] / A.V. Devyatov, A.A. Mansurov, Sh.H. Hashimov [i dr.] // Hirurgiya Uzbekistana [Uzbekistan Surgery]. — 2002. № 1. - C.19-22.

2. Taktika vedeniya bol'nyh s vnepechenochnoi portal'noi gipertenziei posle proshivaniya varikozno-rasshirennyh ven pischevoda i zheludka [Clinical management of patients with extrahepatic portal hypertension after suturing of esophageal varices and gastric] / A.K. Eramishancev, E.A. Kicenko, A.M. Nechaenko, R.S. Grigoryan // Annaly hirurgicheskoi gepatologii [Annals of Surgical Hepatology]. - 2002. - T. 10, № 1. - S.27-32.

3. Mansurov, A.A. Takticheskie aspekty i novye tehnologii razobschayuschih i rekonstruktivnyh shuntiruyuschih operacii u bol'nyh s portal'noi gipertenziei: avtoref. dis. ... d-ra med. nauk [Tactical aspects and new technologies of dissociative and reconstructive bypass surgery in patients with portal hypertension] / A.A. Mansurov. - Tashkent, 2004. - $115 \mathrm{~s}$.

4. External hemorrhage from a portacaval anastomosis in a patient with liver cirrhosis / M. Biyik, R. Ucar, S. Cifci [et al.] // Case Reports Hepatol. — 2014. - Vol. 2014. P.523610-523613.

5. Endoscopic Hemostasis in Acute Esophageal Variceal Bleeding. / A. Cárdenas, A. Baiges, V. Hernandez-Gea, J.C. Garcia-Pagan // Gastroenterol Clin. North Am. 2014. - Vol. 43(4). - P.795-806.

6. Elkrief, L. Prospective Comparison of Spleen and Liver Stiffness by Using Shear-Wave and Transient Elastography for Detection of Portal Hypertension in Cirrhosis / L. Elkrief, P.E. Rautou, M. Ronot [et al.] // Radiology. - 2014. - Vol. 28. - P.141210141214.

7. Fung, J. Management of chronic hepatitis B in severe liver disease / J. Fung, C.L. Lai, M.F. Yuen // World J. Gastroenterol. - 2014. - Vol. 20(43). - P.1605316061.

8. Stefanescu, H. Noninvasive assessment of portal hypertension in cirrhosis: Liver stiffness and beyond / H. Stefanescu, B. Procopet // World J. Gastroenterol. 2014. - Vol. 20(45). - P.16811-16819.

9. Tandon, $P$. Risk of Bacterial Infection in Patients with Cirrhosis and Acute Variceal Hemorrhage, Based on Child-Pugh Class, and Effects of Antibiotics / P. Tandon, J.G. Abraldes, A. Keough [et al.] // Clin. Gastroenterol. Hepatol. - 2014. - Vol. S1542. P.3565-3569. 


\title{
ОПЫТ ОРТОПЕДИЧЕСКОГО ЛЕЧЕНИЯ БОЛЬНЫХ С ЧЕЛЮСТНО-ЛИЦЕВОЙ ПАТОЛОГИЕЙ
}

\begin{abstract}
АЛЛА ИБРАГИМОВНА РАФФ, канд. мед. наук, доцент кафедры ортопедической стоматологии и стоматологии общей практики ГБОУ ДПО «Казанская государственная медицинская академия» Минздрава России, Казань, Россия, тел. 9-904-662-42-28, e-mail: ralla1@rambler.ru
\end{abstract}

Реферат. Цель исследования - провести клиническую оценку эффрективности фрунционального лечения аппаратами с пружинящими плоскостями и их возможности перемещения фрагментов деформированной челюсти и зубов, а также при дисфункциях височно-нижнечелюстного сустава в трех взаимно пересекающихся плоскостях: вертикальной, сагиттальной и трансверзальной. Материал и методы. Проведен анализ и лечение 15 пациентов в возрасте от 16 до 30 лет с посттравматическими и постоперационными деформациями верхней челюсти и заболеваний височно-нижнечелюстного сустава с рентгенологическим контролем, оценкой состояния слизистой полости рта. На 7-е сут было установлено перемещение в вертикальной плоскости до 2 мм, в сагиттальной плоскости - до 2 мм, в трансверзальной плоскости - от 1,5 до 2 мм специальным измерителем со шкалой. Установлено уменьшение патологической симптоматики при дисфункции нижнечелюстного сустава. Результаты и их обсуждение. Установлено, что при применении функциональной аппаратуры с пружинящими плоскостями возможно перемещение деформированных участков челюсти и зубов в трех взаимно пересекающихся плоскостях: вертикальной, сагиттальной, трансверзальной, что создает значительный терапевтический эфффект и реабилитацию больных.

Ключевые слова: функциональные аппараты, пружинящие плоскости.

\section{PRACTICE ORTHOPEDIC TREATMENT OF PATIENTS WITH MAXILLOFACIAL PATHOLOGY}

ALLA I. RAFF, Candidate of Medical Science, associate professor of the Department of prosthodontics and general dentistry of SBEI APE «Kazan State Medical Academy» of Russian Ministry of Health, Kazan, Russia, tel. 9-904-662-42-28, e-mail: ralla1@rambler.ru

\begin{abstract}
The purpose of the study was to conduct a clinical evaluation the effectiveness of treatment by functional devices with springy planes and its capability to move a deformed jaw fragments and teeth. As dysfunction of the temporomandibular joint in three mutually intersecting planes: vertical, sagittal and transversal. Material and methods. There was performed an analysis and treatment of 15 patients aged 16 to 30 years old with post-traumatic and postoperative maxillary deformities and diseases of the temporomandibular joint with fluoroscopic guidance, assessment of the state of the oral mucosa. Observed movements at $7^{\text {th }}$ day with special meter scale: in vertical plane to $2 \mathrm{~mm}$, in sagittal to $2 \mathrm{~mm}$ and from 1,5 to $2 \mathrm{~mm}$ in transversal plane. The decrease of pathological symptoms in temporomandibular joint dysfunction was demonstrated. Results and discussion. It was found that the application of functional equipment with springy planes can move deformed parts of the jaw and teeth in three mutually intersecting planes: vertical, sagittal, transversal which creates a significant therapeutic effect and rehabilitation of patients.
\end{abstract}

Key words: functional devices, springy planes.

$\mathrm{B}$ ведение. В последние годы особенно актуальна проблема лечения целого ряда деформаций прикуса, возникших в результате посттравматических остеомелитов, послеоперационных дефектов челюстей и особенно неправильно сросшихся переломов, возникших в результате несвоевременно начатого лечения или же неправильно проведенного лечения, неправильного репонирования отломков челюстей [2]. Среди лиц, направленных на стационарное лечение, были как первично обратившиеся за специализированной помощью через более чем 3 нед после получения травмы, так и лица, которым уже проводилось ортопедическое лечение, но без должного результата. У таких больных переломы челюстей нередко сопровождаются осложнениями, такими как остеомиелит, нарушения прикуса, замедление сроков консолидации переломов [1, 4].

В тех случаях, когда деформация прикуса уже сложилась, и начался процесс консолидации перелома без ярко выраженного воспалительного процесса, больного сложно убедить пойти на оперативное вмешательство. Проведение ортопедических мероприятий традиционным методом известными шинами не дает нужного результата. Применение шины с пружинящими плоскостями дает возможность одновременно перемещать фрагменты сломанной челюсти в сагиттальной, трансверзальной и вертикальной плоскостях, а применение спиралевидного проволочного активатора дает необходимую стабилизацию и правильную новую консолидацию переломов [8, 9]. Применяя пружинящие плоскости, можно проводить функционально-физиологическое лечение больных с переломами нижней и верхней челюстей [10].

В настоящее время актуален вопрос лечения дисфункции височно-нижнечелюстных суставов. Решение выбора индивидуального функционального аппарата, изготовленного лабораторным путем, позволяет, устраняя конкретную причину заболевания, успешно лечить данную патологию с 
применением аппаратов с пружинящими металлическими плоскостями, трансформируемые по форме, необходимой для перемещения по сагиттальной, трансверзальной и вертикальной плоскостям в каждом конкретном случае [3]. В связи с этим представляется актуальным более широкое внедрение в ежедневную практику врача-стоматолога-хирурга метода функционального лечения травм, полученных в результате переломов верхней челюсти, оперативных вмешательств и окклюзионных нарушений, создающих дисфункциональные нарушения височно-нижнечелюстного сустава.

Функциональный метод этих перечисленных заболеваний создает реальную возможность, консервативно сохраняя целостность тканей, воздействовать конкретно и избирательно на ту область челюсти и зубов, где произошла деформация и нарушения окклюзионных соотношений. В основе метода лежат направленные действия пружинящих элементов с возможной деформацией их по форме, необходимой для перемещения в нужном направлении, адаптированные конкретно на перемещаемую область и зубы. Очень важно отметить возможность сохранения и укрепления тех зубов, которые в результате травмы получили подвижность 1-2-й степени, что создает дилемму о возможном их сохранении.

Именно вопрос о сохранности и целостности зубного ряда позволяет конструировать и адаптировать как лабораторным путем, так и непосредственно в стоматологическом кресле съемную конструкцию, запланированную челюстно-лицевым ортопедом. Эти аппараты (шины) адаптируются и конструируются в каждом конкретном случае индивидуально. Сохранение целостности и жизнеспособности зубов позволяет перемещать фрагменты деформированной верхней челюсти и зубов, восстанавливая окклюзионную кривую.

Предпосылками для разработки функционального метода лечения травм и деформации верхней челюсти были традиционные методы лечения, репонирующие и консолидирующие переломы, выполненные лабораторным путем, такие как шины Сбаржа и Вебера [2].

Хирургические вмешательства с наложением накостных швов либо металлических пластин не позволяют динамично воздействовать на ту область, которую необходимо перемещать, окклюзионно уравновесить и окклюзионно восстановить. Важно отметить ограничение хирургических вмешательств по причине соматических состояний больного, либо его отказы от хирургических вмешательств.

Таким образом, необходимо решать сложные задачи индивидуального изготовления съемных функциональных аппаратов с пружинящими элементами, которые позволяют избирательно воздействовать на конкретную перемещаемую область. Возможность более лучшего гигиенического ухода за съемными аппаратами, полостью рта, проведение лечебных процедур, необходимых в процессе лечения, создает более быстрый эффрект лечения и реабилитации больного.
Наличие биологически стойкого нанопокрытия, нанонитридотитаногафниевого покрытия 2-5 мкм создает стойкий антимикробный эффрект в отношении стафилококка, кишечной палочки, синегнойной палочки, клебсиеллы, улучшает восстановительный период и реабилитацию больного [5]. Цель исследования - провести клиническую оценку эфрфективности функциональных аппаратов (шин) с пружинящими элементами как эффрективного способа лечения травм и деформаций челюстно-лицевой области и дисфункции височно-нижнечелюстного сустава.

Материал и методы. В исследовании принимали участие 15 пациентов в возрасте от 16 до 30 лет с диагнозами, связанными с посттравматическими и постоперационными деформациями, а также с дисфункциями височно-нижнечелюстных суставов (различные этиологии). Выбор пациентом проводился в соответствии со схожестью патологии и положения прикуса, сроков от начала полученных травм, окклюзионных нарушений [6].

Обязательным условием для отбора пациентов явилось наличие устойчивости фриксации аппарата на нижнюю челюсть, санация полости рта, отсутствие деформирующих рубцов в полости рта, отсутствие сопутствующей патологии слизистой полости рта, ткани пародонта, тяжелой патологии внутренних органов, таких как сахарный диабет, сердечнососудистая патология. Всем пациентам назначался 1-й гигиенический режим, режим щадящего питания и ухода за аппаратом. Адаптация к функциональному аппарату проходила одновременно с начатым лечением, не нарушая его по времени воздействия на перемещаемые фрагменты челюсти и зубы. Количество посещений не ограничивалось, динамика наблюдений рассматривалась на 7-е сут от начала лечения. Было установлено, что перемещение фрагментов челюсти и зубов по сагиттальной, трансверзальной и вертикальной плоскостям наблюдается на 7-е сут: по сагиттальной плоскости - до 2 мм, по вертикальной плоскости - до 2 мм, по трансверзальной плоскости - от 1,5 до 2 мм при применении специального измерителя со шкалой. В случаях с дисфункциями височно-нижнечелюстных суставов болевой синдром устранялся на 3-5-е сут, в зависимости от сложности патологии и сроков заболевания. На 7-е сут с начала лечения устранялись отек и гиперемия в области суставов. Степень открывания рта на 10-е сут от начала лечения увеличивается на 10-20 мм, вычисленная специальным измерителем со шкалой. Характерные признаки - щелчок и хруст при открывании и закрывании рта устраняются на 15-20-е сут от начала лечения.

Через 15 сут проводилась коррекция перемещаемых фррагментов челюсти и зубов. В случаях восстановления окклюзионных соотношений нагрузка на данный участок стабилизировалась и не усиливалась. В других отделах продолжала активироваться до полного получения результата. В процессе наблюдения была отмечена большая эффективность лечения и перемещения фрагментов деформированной челюсти и зубов, связанная с одновременным перемещением их в трех взаимно пересекающихся плоскостях, а именно: 
в сагиттальной, вертикальной и трансверзальной. Именно устойчивость и стабилизация в трех взаимно пересекающихся плоскостях, индивидуально скорригированная как единое целое, позволило наблюдать динамику и эффективность применения функциональных аппаратов для лечения травм и деформации челюстно-лицевой области и дисфункций височно-нижнечелюстного сустава.

Результаты и их обсуждение. Применение функциональных аппаратов с пружинящими плоскостями для лечения посттравматических и постоперационных деформаций и дисфункций височно-нижнечелюстных суставов позволяет проводить эфффективное лечение за счет возможности пружинящих элементов, перемещающих фрагменты деформированной челюсти и зубов в трех взаимно пересекающихся плоскостях: в сагиттальной, вертикальной и трансверзальной, что ускоряет сроки лечения и реабилитацию пациентов [6-9]. Перемещение деформированных участков челюсти и зубов на 7-е сут от начала лечения наблюдается по сагиттальной плоскости на 2 мм, по вертикальной плоскости - на 2 мм, по трансверзальной плоскости - от 1,5 до 2 мм при применении специального измерителя со шкалой. В случаях с дисфункциями височно-нижнечелюстных суставов болевой синдром устраняется на 3-5-е сут от начала лечения, устраняется отек и гиперемия в области суставов на 7-е сут от начала лечения, степень открывания рта увеличилась на $10-20$ мм на 10 -е сут от начала лечения, щелчок и хруст при открывании и закрывании рта устранялись на 15-20-е сут от начала лечения.

Применение биологически стойкого нанопокрытия 2-5 мкм создает устойчивый бактерицидный и дополнительный лечебный эффект. Результаты осмотра через 30 дней показали положительную динамику в лечении в виде отсутствия жалоб, стабилизации окклюзионной кривой, уменьшении подвижности зубов, имевших подвижность 1-2-й степени до начала лечения, уменьшение десневых карманов этих зубов. В случаях с дисфункциями височно-нижнечелюстного сустава были отмечены отсутствие жалоб на боль при открывании и закрывании рта, отечность, гиперемию, хруст и щелчок.

Таким образом, применение функциональных аппаратов с пружинящими элементами позволяет эффективно решать задачи в лечении посттравматических деформаций и заболеваний височнонижнечелюстных суставов, оказывает неоценимую помощь в работе врачу-стоматологу-хирургу в лечении сложных челюстно-лицевых заболеваний.

На отдаленных сроках наблюдения (2, 3, 6 мес) сохранялась стабильность достигнутого результата и восстановление окклюзионной кривой. В случаях с имеющимися до проводимого лечения потерей зубов было проведено протезирование как съемными, так и несъемными протезами по показаниям с целью стабилизации окклюзионных соотношений и реабилитации пациентов.

Вывод. При лечении посттравматических и постоперационных деформаций и дисфункций височно-нижнечелюстного сустава применение функциональных аппаратов с пружинящими элементами позволяет ускорять процесс реабилитации и лечения больных за счет одновременного перемещения деформированных участков челюстей и зубов в трех взаимно пересекающихся плоскостях: в сагиттальной, вертикальной и трансверзальной.

Применение биологически стойкого нанопокрытия создает дополнительный лечебный эффрект с целью сокращения сроков лечения и реабилитации больных с челюстно-лицевыми патологиями и дисфункциями височно-нижнечелюстного сустава.

\section{ЛИТЕРАТУРА}

1. Байриков, И.М. Сравнительная оценка методов лечения больных с переломами нижней челюсти и их клинико-функциональное обследование: автореф. дис. ... канд. мед. наук / И.М. Байриков. - Калинин, 1987. - 17 c.

2. Дмитриева, В.С. Переломы нижней челюсти (не огнестрельные) и их лечение: учеб. пособие/ В.С. Дмитриева. - М.: Ун-т дружбы народов, 1984. - 84 с.

3. Куроедов, В.Д. Изменения в жевательных мышцах височно-нижнечелюстном суставе и околозубных тканях при мезиальном перемещении нижней челюсти в эксперименте/ В.Д. Куроедов, Л.П. Григорьева, В.А. Сирык // Казанский вестник стоматологии. 1995. - № 1. - C.15-17.

4. Патент А.с. № 1678354 СССР, МПК ${ }^{4}$ А61 K 31/21, А 61 Р 23/02. Назубная шина / В.М. Кулагин, О.Е. Малевич, Г.И. Емельянов; заявитель и патентообладатель ГОУ ВПО «Днепропетровский медицинский институт». № 4746408/14; заявл. 03.10.1989; опубл. 23.09.1991, Бюл. № 35. - 2 c.

5. Исследование антимикробных свойств некоторых металлов и покрытий для медицинских изделий / Ф.Г. Студеникина, М.М. Миронов, В.П. Денисов [и др.] // Медицинская техника: сб. - М., 1993. - № 5. C.6-8.

6. Патент 87079. Рос. Федерация, МПК ${ }^{8}$ А 61 K 31/21, А 61 Р 23/02. Устройство для лечения дисффункций височнонижнечелюстного сустава / И.Ш. Абдуллин, А.И. Рафрф, Н.И. Шаймиева; заявитель и патентообладатель ГОУ ВПО «Казанский государственный технологический университет». - № 2009121042; заявл. 02.06.2009; опубл. 27.09.2009, Бюл. № 35. - 4 c.

7. Патент 88935. Рос. Федерация, МПК ${ }^{8}$ A61 K 31/21, А 61 Р 23/02. Устройство для лечения диссрункций височнонижнечелюстного сустава / И.Ш. Абдуллин, А.И. Раффф, Н.И. Шаймиева; заявитель и патентообладатель ГОУ ВПО «Казанский государственный технологический университет». - № 2009121043; заявл. 02.06.2009; опубл. 27.11.2009, Бюл. № 26. - 4 с.

8. Патент 2290146. Рос. Федерация, МПК ${ }^{8}$ А61 K 31/21, А $61 \mathrm{P} 23 / 02$. Шина для лечения переломов альвеолярного отростка верхней челюсти / И.Ш. Абдуллин, М.М. Миронов, А.И. Раффф, И.Г. Ямашев; заявитель и патентообладатель ГОУ ВПО «Казанский государственный технологический университет». - № 2005111501; заявл. 18.04.2005; опубл. 27.12.2006, Бюл. № 36. - 4 с.

9. Патент 56170. Рос. Федерация, МПК ${ }^{8}$ A61 K 31/21, А 61 P 23/02. Шина для лечения переломов тела верхней челюсти / И.Ш. Абдуллин, М.М. Миронов, А.И. Раффф, И.Г. Ямашев; заявитель и патентообладатель ГОУ ВПО «Казанский государственный технологический университет». - № 2005111500; заявл. 18.04.2005; опубл. 10.09.2006, Бюл. № 25. - 4 c.

10. Ямашев, И.Г. Назубно-десневые шины для лечения переломов челюстей / И.Г. Ямашев, А.И. Раффф // 
Актуальные вопросы челюстно-лицевой хирургии и стоматологии. - СПб., 1997. - С.66-67.

\section{REFERENCES}

1. Bairikov, I.M. Sravnitel'naya ocenka metodov lecheniya bol'nyh s perelomami nizhnei chelyusti i in klinikofunkcional'noe obsledovanie [Comparative evaluation of methods of treatment of patients with mandibular fractures and their clinical and functional examination]: avtoref. dis. ... kand. med. nauk / I.M. Bairikov. — Kalinin, 1987. $-17 \mathrm{~s}$.

2. Dmitrieva, V.S. Perelomy nizhnei chelyusti (ne ognestrel'nye) i in lechenie: ucheb. posobie [Mandibular fractures (not gunshot) and their treatment: a tutorial] / V.S. Dmitrieva. - M.: Un-t druzhby narodov, 1984. $84 \mathrm{~s}$.

3. Kuroedov, V.D. Izmeneniya $\vee$ zhevatel'nyh myshcah visochno-nizhnechelyustnom sustave i okolozubnyh tkanyah pri mezial'nom peremeschenii nizhnei chelyusti $v$ eksperimente [Changes in masticatory muscles temporomandibular joint and periodontal tissues in the mesial movement of the lower jaw in the experiment] / V.D. Kuroedov, L.P. Grigor'eva, V.A. Siryk // Kazanskii vestnik stomatologii. - 1995. — № 1. - S.15-17.

4. Patent A.s. № 1678354 SSSR, MPK4 A61 K 31/21, A 61 P 23/02. Nazubnaya shina [Tooth Splint] / V.M. Kulagin, O.E. Malevich, G.I. Emel'yanov; zayavitel' i patentoobladatel' GOU VPO «Dnepropetrovskii medicinskii institute». — № 4746408/14; zayavl. 03.10.1989; opubl. 23.09.1991, Byul. № 35. - 2 s.

5. Issledovanie antimikrobnyh svoistv nekotoryh metallov i pokrytii dlya medicinskih izdelii [Investigation of antimicrobial properties of some metals and coatings for medical devices] / F.G. Studenikina, M.M. Mironov, V.P. Denisov [i dr.] // Medicinskaya tehnika: sb. - M., 1993. — № 5. - S.6-8.
6. Patent 87079. Ros. Federaciya, MPK8 A61 K 31/21, A 61 P 23/02. Ustroistvo dlya lecheniya disfunkcii visochnonizhnechelyustnogo sustava [The device for the treatment of Temporomandibular joint dysfunction] / I.Sh. Abdullin, A.I. Raff, N.I. Shaimieva; zayavitel' i patentoobladatel' GOU VPO «Kazanskii gosudarstvennyi tehnologicheskii universitet». — № 2009121042; zayavl. 02.06.2009; opubl. 27.09.2009, Byul. № 35. - 4 s.

7. Patent 88935. Ros. Federaciya, MPK8 A61 K 31/21, A 61 P 23/02. Ustroistvo dlya lecheniya disfunkcii visochnonizhnechelyustnogo sustava [The device for the treatment of Temporomandibular joint dysfunction] / I.Sh. Abdullin, A.I. Raff, N.I. Shaimieva; zayavitel' i patentoobladatel' GOU VPO «Kazanskii gosudarstvennyi tehnologicheskii universitet». — № 2009121043; zayavl. 02.06.2009; opubl. 27.11.2009, Byul. № 26. - 4 s.

8. Patent 2290146. Ros. Federaciya, MPK8 A61 K 31/21, A61 P 23/02. Shina dlya lecheniya perelomov al'veolyarnogo otrostka verhnei chelyusti [Splint for the treatment of fractures of the alveolar process of maxilla] / I.Sh. Abdullin, M.M. Mironov, A.I. Raff, I.G. Yamashev; zayavitel' i patentoobladatel' GOU VPO «Kazanskii gosudarstvennyi tehnologicheskii universitet». - № 2005111501; zayavl. 18.04.2005; opubl. 27.12.2006, Byul. № 36. - 4 s.

9. Patent 56170. Ros. Federaciya, MPK8 A61 K 31/21, A 61 P 23/02. Shina dlya lecheniya perelomov tela verhnei chelyusti [Splint for the treatment of fractures of the body of the maxilla] / I.Sh. Abdullin, M.M. Mironov, A.I. Raff, I.G. Yamashev; zayavitel' i patentoobladatel' GOU VPO «Kazanskii gosudarstvennyi tehnologicheskii universitet». — № 2005111500; zayavl. 18.04.2005; opubl. 10.09.2006, Byul. № 25. - $4 \mathrm{~s}$.

10. Yamashev, I.G. Nazubno-desnevye shiny dlya lecheniya perelomov chelyustei [Tooth-gingival splints for the treatment of fractures of the jaws] / I.G. Yamashev, A.I. Raff // Aktual'nye voprosy chelyustno-licevoi hirurgii i stomatologii. — SPb., 1997. - C.66-67.

\section{ХАРАКТЕР АССОЦИАЦИЙ ПОЛИМОРФИЗМА ГЕНА АПОЛИПОПРОТЕИНА В- 100 С НАРУШЕНИЯМИ ЛИПИДНОГО ОБМЕНА У БОЛЬНЫХ ЖЕЛЧНОКАМЕННОЙ БОЛЕЗНЬЮ}

АЛИЯ АЛЬФРИДОВНА САГДАТОВА, аспирант кафедры пропедевтики внутренних болезней ГБОУ ВПО «Башкирский государственный медицинский университет» Минздрава России, Уфа, Россия, тел. 8-917-772-59-60, e-mail: aliyasg@rambler.ru

АЛЬФИЯ ХАМАТЬЯНОВНА НУРГАЛИЕВА, канд. биол. наук, доцент кафедры генетики и фундаментальной медицины ФГБОУ ВПО «Башкирский государственный университет», тел. (347) 2-299-671, e-mail: Alfiyakh83@gmail.com ЭЛЬЗА КАМИЛЕВНА ХУСНУТДИНОВА, докт. биол. наук, проф., зав. кафедрой генетики и фундаментальной медицины ФГБОУ ВПО «Башкирский государственный университет», зав. отделом геномики и лабораторией молекулярной генетики человека ФГБУН «Институт биохимии и генетики, Уфимский научный центр РАН», Уфа, Россия, тел. (347)-2-299-671, e-mail: biodekanat@yandex.ru

ШАМИЛЬ ЗАРИФОВИЧ ЗАГИДУЛЛИН, докт. мед. наук, проф., зав. кафедрой пропедевтики внутренних болезней ГБОУ ВПО «Башкирский государственный медицинский университет» Минздрава России, Уфа, Россия, тел. (347) 246-53-97, e-mail: zshamil@inbox.ru

\footnotetext{
Реферат. Цель исследования - анализ связи полиморфного варианта rs693 гена APOB-100 с нарушениями липидного обмена у больных с желчнокаменной болезнью и у практически здоровых лиц, проживающих в г. Уфе Республики Башкортостан. Материал и методы. 54 пациента с диагнозом «желчнокаменная болезнь» были разделены на 2 группы: 1-я группа - больные с хроническим калькулезным холециститом (21 пациент), 2-я группа - больные с острым калькулезным холециститом (33 пациента). Проведен анализ липидного профиля сыворотки крови больных и типирование полиморфного локуса rs693 гена АРОВ-100. Результаты и их обсуждение. Выявлено, что для желчнокаменной болезни маркером повышенного риска развития заболевания является генотип X+X-полиморфного варианта rs693 гена APOB-100. В сыворотке крови больных с данной патологией установлен повышенный уровень холестерина липопротеинов низкой плотности и высокий риск атеросклероза
} 
(индекс атерогенности - больше 4). Была установлена взаимосвязь между нарушениями обмена липидов крови и ЖКБ. Заключение. Определено влияние полиморфного варианта rs693 гена APOB-100 на метаболизм липидов и его нарушения у пациентов с желчнокаменной болезнью.

Ключевые слова: желчнокаменная болезнь, полиморфизм гена аполипопротеина $B-100$, липопротеины.

\title{
NATURE ASSOCIATION OF POLYMORPHISM GENE APOLIPOPROTEIN B-100 WITH LIPID METABOLISM IN PATIENTS WITH CHOLELITHIASIS
}

ALIYA A. SAGDATOVA, graduate student of the Department of internal medicine propaedeutics of SBEI HPE "Bashkir State Medical University» of Russian Ministry of Health, Ufa, Russia, tel. 8-917-772-59-60, e-mail: aliyasg@rambler.ru ALFIA KH. NURGALIEVA, Candidate of Medical Science, associate professor of the Department of genetics and fundamental medicine of FSBEI HPE «Bashkir State University», tel. (347) 2-299-671, e-mail: Alfiyakh83@gmail.com

ELSA K. KHUSNUTDINOVA, Doctor of Biological Science, Professor, Head of the Department of genetics and fundamental Medicine of FSBEI HPE «Bashkir State University», Head of the Department of genomics and human genetics laboratory of molecular of FSBDS «Institute of Biochemistry and Genetics, Ufa Scientific Center, Russian Academy of Sciences", Ufa, Russia, tel. (347) 2-299-671, e-mail: biodekanat@yandex.ru

SHAMIL Z. ZAGIDULLIN, Doctor of Medical Science, Professor, Head of the Department of internal medicine propaedeutics, of SBEI HPE «Bashkir State Medical University» of Russian Ministry of Health, Ufa, Russia, tel. (347) 246-53-97, e-mail: zshamil@inbox.ru

\begin{abstract}
Aim - analysis of the relationship of the polymorphic variant gene rs693 APOB-100 with lipid metabolism in patients with gallstone disease and healthy individuals residing in the Republic of Bashkortostan, Ufa. Material and methods. 54 patients with gallstone disease were divided into 2 groups: group 1 - patients with chronic calculous cholecystitis (21 patients), 2 group - patients with acute calculous cholecystitis (33 patients). Analysis of the lipid profile of blood serum of patients and typing of polymorphic gene locus rs693 APOB-100. Results. It was found that for gallstone disease marker of increased risk of disease is X+X-genotype of a polymorphic variant gene rs693 APOB100. In the serum of patients with this pathology is set elevated levels of low density lipoprotein cholesterol and a high risk of atherosclerosis. It was established relationship between disorders of lipid metabolism and gallstone disease. Conclusion. The effect of the polymorphic variant gene rs693 APOB-100 on lipid metabolism and its disorders in patients with cholelithiasis.
\end{abstract}

Key words: cholelithiasis, gene polymorphism of apolipoprotein B-100, lipoproteins.

3 ведение. Желчнокаменная болезнь (ЖКБ) широко распространена во всем мире, в среднем $10-15 \%$ населения в мире страдает этим заболеванием [2]. Клинически ЖКБ может протекать в виде хронического калькулезного холецистита (XKX) и острого калькулезного холецистита (ОКХ). Причиной возникновения холестериновых желчных камней являются нарушения обмена веществ в организме, в том числе и нарушения липидного обмена [14]. Многочисленные эпидемиологические исследования выявили взаимосвязь между нарушением обмена липидов в плазме крови и желчнокаменной болезнью, особенно снижение уровня липопротеинов высокой плотности (ЛПВП), повышение уровня холестерина липопротеинов низкой плотности (ЛПНП) и триглицеридов [1]. Гиперлипидемия считается важным фактором риска развития сердечно-сосудистых заболеваний в основном из-за ее связи со значительным влиянием холестерина на развитие атеросклероза [3]. ЖКБ является многофакторным заболеванием, при этом в гомеостазе холестерина участвует большое количество генов - основного компонента конкрементов [13].

Цель исследования - изучение связи полиморфного варианта rs693 гена APOB-100 с нарушениями липидного обмена у больных желчнокаменной болезнью и практически здоровых лиц, проживающих в г. Уфее Республики Башкортостан.

Материал и методы. Материалом для исследования послужили образцы ДНК больных желчнокаменной болезнью в стадии обострения и практически здоровых лиц (контрольная группа) в возрасте от 23 до 80 лет. Группа больных, наблюдавшихся в гастроэнтерологическом и хирургическом отделениях ГБУЗ РБ ГКБ № 21 г. Уфы, составила 54 человека (21 пациент с диагнозом хронический калькулезный холецистит (XKX) - 1-я группа, 33 пациента с острым калькулезным холециститом (ОКХ) - 2-я группа, у которых проведено изучение связи полиморфного варианта rs693 гена APOB-100 с нарушениями липидного обмена. Диагностику ЖКБ проводили на основании данных общеклинического обследования, ультразвукового исследования желчного пузыря, также был проанализирован липидный профриль сыворотки крови. В качестве контроля исследована группа практически здоровых лиц без каких-либо признаков заболеваний желудочнокишечного тракта, а также сердечно-сосудистой патологии, обусловленной атеросклерозом, состоящая из 22 человек. Распределение по половому признаку среди больных было следующим: мужчин - 16, женщин - 38, среди индивидов контрольной группы: мужчин - 6, женщин - 16.

Геномную ДНК выделяли из лимфоцитов периферической крови методом фенольно-хлороформной экстракции [10]. Амплификацию исследованных локусов ДНК проводили с помощью полимеразной цепной реакции синтеза ДНК на амплификаторе «GeneAmp PCR System 2720» производства компании «Applied Biosystems» (США). Определение нуклеотидных замен проводили методом анализа 
Полиморфные варианты, последовательности праймеров, номенклатура аллелей анализируемого ДНК-локуса

\begin{tabular}{|c|c|c|c|}
\hline Ген & $\begin{array}{c}\text { Полиморфный вариант, } \\
\text { dbSNP }\end{array}$ & Праймеры, 5' - 3' (ссылка) & $\begin{array}{c}\text { Рестриктаза, аллели } \\
\text { (размер фррагментов п.н.) }\end{array}$ \\
\hline APOB-100 & $\begin{array}{c}7673 \mathrm{C}>\text { T } \\
\text { rs693 }\end{array}$ & $\begin{array}{c}\text { GGAGACTATTCAGAAGCTAA } \\
\text { GAAGAGCCTGAAGACTGACT } \\
\text { (Jaime S.-C. et al., 2010) }\end{array}$ & $\begin{array}{c}\text { Xbal } \\
X \text { C) }-710\end{array}$ \\
\hline
\end{tabular}

полиморфизма длин рестрикционных фррагментов (ПДРФ-анализ). Перечень исследованных локусов, последовательности праймеров, размеры амплифрицируемых фррагментов, названия рестриктаз представлены в табл. 1.

Результаты оценивали методом электрофореза в 2\% агарозном геле с последующим окрашиванием бромистым этидием и визуализацией в проходящем ультрафиолетовом свете. Статистическую обработку результатов исследования проводили с применением программного обеспечения MS Office Excel. Оценка различий между двумя исследуемыми выборками проводилась по U-критерию Манна - Уитни [12]. Забор крови для определения липидных фракций осуществлялся после 12-часового голодания. Энзиматическим методом определяли в сыворотке крови концентрацию общего холестерина (ОХС), холестерина липопротеинов высокой плотности (ХС ЛПВП), триглицеридов (ТГ), используя коммерческие наборы Biocon (Германия) на автоанализаторе Labsystem (Финляндия). Расчет индекса атерогенности (ИА) проводился по формуле ИА = (ОХС - ХС ЛПВП)/XС ЛПВП. Индекс атерогенности в пределах 3,0-4,0 ассоциировался с умеренным, а больше 4,0 - с высоким риском атерогенности [4]. Все пациенты предварительно дали письменное согласие на участие в проводимом исследовании.
Результаты и их обсуждение. У больных желчнокаменной болезнью и лиц контрольной группы проведен анализ связи полиморфного варианта rs693 гена $A P O B-100$ с нарушениями липидного обмена (табл. 2).

Во всех исследованных группах наиболее часто встречался гетерозиготный генотип $X+X-(54,55-$ $61,9 \%$ случаев среди больных ЖКБ, $41 \%$ - в контрольной группе), гомозиготные генотипы $X+X+$ и $X-X$-встречались примерно с равной частотой. Среди больных в отдельные группы для исследования были выделены лица с диагнозами «хронический калькулезный холецистит» и «острый калькулезный холецистит». При сравнении их с объединенной выборкой лиц контрольной группы выявлено, что при развитии ЖКБ маркером повышенного риска является гетерозиготный генотип $X+X-A P O B-100$, который встречается среди пациентов с частотой 54,55-61,9\%, а в контроле - 41\%.

В результате анализа связи генотипов $A P O B-100$ с липидами крови больных выявлено, что носители гетерозиготного генотипа $\mathrm{X}+\mathrm{X}-$ в 1-й группе больных имели статистически достоверно низкий уровень холестерина ЛПВП и высокий холестерина ЛПНП, а также высокий риск атеросклероза (индекс атерогенности составил более 4,0) по сравнению с контрольной группой, причем пока-

Результаты анализа ассоциации исследуемого полиморфного варианта rs693 гена APOB-100 с показателями липидов крови (M \pm m) больных ЖКБ по сравнению с контрольной группой

\begin{tabular}{|c|c|c|c|c|c|c|c|}
\hline & \multirow[b]{2}{*}{ Генотип } & \multicolumn{5}{|c|}{ Показатели липидов крови (M \pm m), ммоль/л } & \multirow[b]{2}{*}{$\mathrm{N}$} \\
\hline & & $\begin{array}{c}\text { Общий } \\
\text { холестерин }\end{array}$ & Триглицериды & $\begin{array}{c}\text { Холестерин } \\
\text { лПВП }\end{array}$ & $\begin{array}{c}\text { Холестерин } \\
\text { лПнП }\end{array}$ & $\begin{array}{c}\text { Индекс атероген- } \\
\text { ности (ИА) }\end{array}$ & \\
\hline \multirow[t]{3}{*}{ Больные с XKX } & $X+X+(n=4)$ & $\begin{array}{c}5,99 \pm 0,26^{*} \\
p=0,004\end{array}$ & $\begin{array}{c}1,30 \pm 0,24^{*} \\
p=0,011\end{array}$ & $\begin{array}{c}1,34 \pm 0,08 \\
p=0,817\end{array}$ & $\begin{array}{c}4,05 \pm 0,23^{*} \\
p=0,007\end{array}$ & $\begin{array}{c}3,51 \pm 0,34 \\
p=0,076\end{array}$ & \multirow{3}{*}{21} \\
\hline & $X+X-(n=13)$ & $\begin{array}{c}5,32 \pm 0,35 \\
p=0,698\end{array}$ & $\begin{array}{c}1,71 \pm 0,23 \\
p=0\end{array}$ & $\begin{array}{c}1,08 \pm 0,05^{*} \\
p=0,038\end{array}$ & $\begin{array}{c}3,39 \pm 0,25^{*} \\
p=0,003\end{array}$ & $\begin{array}{c}3,92 \pm 0,30^{*} \\
p=0,01\end{array}$ & \\
\hline & $X-X-(n=4)$ & $\begin{array}{c}6,04 \pm 0,61 \\
p=0,094\end{array}$ & $\begin{array}{c}2,18 \pm 0,39 \\
p=0,07\end{array}$ & $\begin{array}{c}1,04 \pm 0,08^{*} \\
p=0,049\end{array}$ & $\begin{array}{c}3,85 \pm 0,74 \\
p=0,1\end{array}$ & $\begin{array}{c}4,81 \pm 0,43^{*} \\
p=0,005\end{array}$ & \\
\hline \multirow[t]{3}{*}{ Больные с ОКХ } & $X+X+(n=5)$ & $\begin{array}{c}5,46 \pm 0,17 \\
p=0,055\end{array}$ & $\begin{array}{c}1,18 \pm 0,27 \\
p=0,383\end{array}$ & $\begin{array}{c}1,08 \pm 0,14 \\
p=0,123\end{array}$ & $\begin{array}{c}2,64 \pm 0,49 \\
p=0,591\end{array}$ & $\begin{array}{c}4,41 \pm 0,68 \\
p=0,052\end{array}$ & \multirow{3}{*}{33} \\
\hline & $X+X-(n=18)$ & $\begin{array}{c}5,57 \pm 0,19 \\
p=0\end{array}$ & $\begin{array}{c}1,11 \pm 0,12^{*} \\
p=0,021\end{array}$ & $\begin{array}{c}1,19 \pm 0,09 \\
p=0,149\end{array}$ & $\begin{array}{c}2,98 \pm 0,21^{*} \\
p=0,04\end{array}$ & $\begin{array}{c}3,93 \pm 0,33^{*} \\
p=0,035\end{array}$ & \\
\hline & $X-X-(n=10)$ & $\begin{array}{c}5,26 \pm 0,58 \\
p=0,087\end{array}$ & $\begin{array}{c}1,46 \pm 0,13 \\
p=0\end{array}$ & $\begin{array}{c}0,94 \pm 0,10^{*} \\
p=0,006\end{array}$ & $\begin{array}{c}2,58 \pm 0,29 \\
p=0,792\end{array}$ & $\begin{array}{c}4,78 \pm 0,45^{\star} \\
p=0,001\end{array}$ & \\
\hline \multirow[t]{3}{*}{ Контроль } & $X+X+(n=5)$ & $4,92 \pm 0,01$ & $0,75 \pm 0,08$ & $1,61 \pm 0,26$ & $2,63 \pm 0,21$ & $2,48 \pm 0,36$ & \multirow{3}{*}{22} \\
\hline & $X+X-(n=9)$ & $4,91 \pm 0,008$ & $0,79 \pm 0,06$ & $1,39 \pm 0,13$ & $2,29 \pm 0,16$ & $2,86 \pm 0.23$ & \\
\hline & $X-X-(n=8)$ & $4,9 \pm 0,009$ & $0,85 \pm 0,07$ & $1,5 \pm 0,17$ & $2,50 \pm 0,15$ & $2,60 \pm 0,25$ & \\
\hline
\end{tabular}

Примечание: $n$ - численность групп; N - объем выборки, *по сравнению с контролем $(p<0,05)$. 


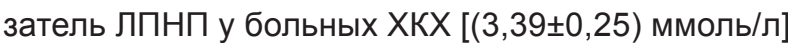
был гораздо более высоким, чем у пациентов с ОКХ $[(2,98 \pm 0,21)$ ммоль/л]. Во 2-й группе носители генотипа X+X- APOB-100 имели статистически значимые повышенные показатели ЛПНП и высокий риск атеросклероза (индекс атерогенности составил более 4,0). Носители гомозиготного генотипа X+X+ в 1-й группе имели достоверно высокие уровни общего холестерина и холестерина ЛПНП. У больных ОКХ и ХКХ с генотипом X-X- наблюдался статистически значимый низкий уровень ЛПВП и высокий риск атеросклероза (индекс атерогенности составил более 4,0).

Аполипопротеин В-100 (АРОВ-100) образуется в печени, содержится в липопротеинах очень низкой плотности (ЛПОНП), липопротеинах промежуточной плотности (ЛППП) и липопротеинах низкой плотности (ЛПНП), играет важную роль в метаболизме и транспорте холестерина в плазме крови. В экзоне 26, расположенного на хромосоме 2-го гена $A P O B$, идентифицирована однонуклеотидная замена $7673 C>T$ (rs693), часто описываемая в литературе как Xbaполиморфозм [6].

Результаты исследования ассоциации $\mathrm{Xbal}$ полиморфизма гена $A P O B-100$ с риском развития ЖКБ в разных странах весьма противоречивы. Так, T. Han et al. (2000), а позднее и F.L. Liu et al. (2010) выявили, что у больных ЖКБ из Китая чаще по сравнению с группой здоровых лиц встречался генотип $X+X-$ и аллель $X+[8,9]$. Проведенные в 2010 г. в Мексике исследования J. Sánchez-Cuén et al. (2010) не подтвердили существования статистически значимой связи данного полиморфного варианта гена $A P O B-100$ с развитием камней в желчном пузыре [11]. B 2013 г. Y. Gong et al. (2013) опубликовали результаты метаанализа, объединяющего данные 16 исследований, посвященных анализу ассоциаций полиморфных вариантов гена $A P O B-100$ с ЖКБ и раком желчного пузыря. Авторы установили, что $X+X+$ генотип может быть ассоциирован со снижением риска развития рака желчного пузыря среди населения Китая [7]. Другие многочисленные эпидемиологические исследования также выявили взаимосвязь между нарушением обмена липидов в плазме крови и желчнокаменной болезнью. P.J. Banim et al. (2011) отметили связь между уровнем холестерина крови, ЛПНП и риском развития ЖКБ [5]. Г.Е. Ройтберг и др. выявили, что ЛПНП и ЛПОНП наиболее богаты соответственно ХС и ТГ, и при увеличении ЛПНП и ЛПОНП имеется высокий риск развития атеросклероза и патогенетически связанных с ним заболеваний [4].

\section{Выводы:}

1. Для развития желчнокаменной болезни маркером повышенного риска является гетерозиготный генотип $X+X$ - полиморфного варианта rs693 гена APOB-100. Установлено достоверное увеличение концентрации холестерина ЛПНП, низкий уровень холестерина ЛПВП и высокий риск атеросклероза у больных ЖКБ с полиморфным вариантом rs693 гена $A P O B-100$.
2. У больных хроническим калькулезным холециститом с гомозиготным генотипом $X+X+$ наблюдался высокий уровень общего холестерина, а у пациентов с острым калькулезным холециститом с генотипом X-X- - низкий уровень ЛПВП.

\section{ЛИТЕРАТУРА}

1. Гаценко, В.П. Целесообразность комплексного подхода при коррекции липидных нарушений у больных желчнокаменной болезнью и холестерозом желчного пузыря / В.П. Гаценко, Е.Р. Атькова, Р.А. Иванченкова // Лечащий врач. - 2011. - № 7. - С.15-19.

2. Григорьева, И.Н. Липидный обмен и желчнокаменная болезнь / И.Н. Григорьева, Ю.П. Никитин. - Новосибирск: МЕГАГРАФИКС, 2005. - С.160-169.

3. Ребров, А.П. Особенности дислипидемии при псориатическом артрите: взаимосвязь с атеросклерозом, факторами сердечно-сосудистого риска и системным воспалением / А.П. Ребров, И.З. Гайдукова // Саратовский научно-медицинский журнал. -2010 . - Т. 6 , вып. 3. - С.51-55

4. Ройтберг, Г.Е. Внутренние болезни. Сердечнососудистая система / Г.Е. Ройтберг, А.В. Струтынский. - М.: БИНОМ, 2007. - С.314-315.

5. Banim, P.J. The aetiology of symptomatic gallstones quantification of the effects of obesity, alcohol and serum lipids on risk. Epidemiological and biomarker data from a UK prospective cohort study (EPIC-Norfolk) / P.J. Banim, R.N. Luben, H. Bulluck [et al.] // Eur. J. Gastroenterol. Hepatol. - 2011. - Vol. 23(8). - P.733-740.

6. Blackhart, B.D. Structure of the human apolipoprotein B gene / B.D. Blackhart, E.M. Ludwig, V.R. Pierotti [et al.] // J. Biol. Chem. - 1986. - Vol. 261. - P.15364-15367.

7. Gong, Y. Roles of APOB-100 Gene Polymorphisms and the Risks of Gallstones and Gallbladder Cancer: A MetaAnalysis / Y. Gong, L. Zhang, P. Bie, H. Wang // PLoS ONE. — Vol. 8(4). — e61456/ P. 1—9; doi:10.1371/journal. pone.0061456

8. Han, T. Apolipoprotein B-100 gene Xba I polymorphism and cholesterol gallstone disease / T. Han, Z. Jiang, G. Suo, S. Zhang // Clin. Genet. - 2000. - Vol. 57. P.304-308.

9. Liu, F.L. Xba I polymorphisms of apolipoprotein B gene: Another risk factor of gallstone formation after radical gastrectomy / F.L. Liu, W.B. Lu, W.X. Niu // World J. Gastroenterol. - 2010. — Vol. 16(i.20). - P. 25492553.

10. Mathew, C.C. The isolation of high molecular weight eukaryotic DNA / C.C. Mathew // Methods molecular biology. N.Y. - 1984. - Vol. 2. - P.31-34.

11. Sánchez-Cuén, J. APOB-100, APOE and CYP7A1 gene polymorphisms in Mexican patients with cholesterol gallstone disease / J. Sánchez-Cuén, M. Aguilar-Medina, E. Arámbula-Meraz [et al.] // World J. Gastroenterol. 2010. - Vol. 16, issue 37. - P.4685-4690.

12. Schlesselman, J. Case-control studies. Design, conduct, analysis / J. Schlesselman. - N.Y., Oxford: Oxford University Press. - 1982. - P.457.

13. Stinton, L.M. Epidemiology of Gallbladder Disease: Cholelithiasis and Cancer / L.M. Stinton, E.A. Shaffer // Gut and Liver. - 2012. - Vol. 6, № 2. - P.172-187.

14. Yoo, E.-H. The prevalence and risk factors for gallstone disease / E.-H. Yoo, S.-Y. Lee // Clin. Chem. Lab. Med. 2009. — Vol. 47, № 7. — P.795-807.

\section{REFERENCES}

1. Gacenko, V.P. Celesoobraznost' kompleksnogo podhoda pri korrekcii lipidnyh narushenii u bol'nyh zhelchnokamennoi 
bolezn'yu i holesterozom zhelchnogo puzyrya [The feasibility of an integrated approach for the correction of lipid abnormalities in patients with cholelithiasis and gallbladder cholesterosis] / V.P. Gacenko, E.R. At'kova, R.A. Ivanchenkova // Lechaschii vrach [The attending physician]. — 2011. — № 7. - S.15-19.

2. Grigor'eva, I.N. Lipidnyi obmen i zhelchnokamennaya bolezn' [Lipid metabolism and gallstones] / I.N. Grigor'eva, Yu.P. Nikitin. - Novosibirsk: MEGAGRAFIKS, 2005. C. $160-169$.

3. Rebrov, A.P. Osobennosti dislipidemii pri psoriaticheskom artrite: vzaimosvyaz' s aterosklerozom, faktorami serdechno-sosudistogo riska i sistemnym vospaleniem [Features dyslipidemia in psoriatic arthritis: correlation with atherosclerosis, factors of cardiovascular risk and systemic inflammation] / A.P. Rebrov, I.Z. Gaidukova // Saratovskii nauchno-medicinskii zhurnal [Saratov Journal of Medical Scientific]. - 2010. - T. 6, vyp. 3. - S.51-55.

4. Roitberg, G.E. Vnutrennie bolezni. Serdechno-sosudistaya sistema [Internal Medicine. Cardiovascular system] / G.E. Roitberg, A.V. Strutynskii. — M.: BINOM, 2007. S.314-315.

5. Banim, P.J. The aetiology of symptomatic gallstones quantification of the effects of obesity, alcohol and serum lipids on risk. Epidemiological and biomarker data from a UK prospective cohort study (EPIC-Norfolk) / P.J. Banim, R.N. Luben, H. Bulluck [et al.] // Eur. J. Gastroenterol. Hepatol. - 2011. - Vol. 23(8). - P.733-740.

6. Blackhart, B.D. Structure of the human apolipoprotein B gene / B.D. Blackhart, E.M. Ludwig, V.R. Pierotti [et al.] // J. Biol. Chem. - 1986. — Vol. 261. — P.15364-15367.
7. Gong, Y. Roles of APOB-100 Gene Polymorphisms and the Risks of Gallstones and Gallbladder Cancer: A MetaAnalysis / Y. Gong, L. Zhang, P. Bie, H. Wang // PLoS ONE. — Vol. 8(4). — e61456/ P. 1—9; doi:10.1371/journal. pone.0061456

8. Han, T. Apolipoprotein B-100 gene Xba I polymorphism and cholesterol gallstone disease / T. Han, Z. Jiang, G. Suo, S. Zhang // Clin. Genet. - 2000. — Vol. 57. P.304-308.

9. Liu, F.L. Xba I polymorphisms of apolipoprotein B gene: Another risk factor of gallstone formation after radical gastrectomy / F.L. Liu, W.B. Lu, W.X. Niu // World J. Gastroenterol. - 2010. — Vol. 16(i.20). - P. 25492553.

10. Mathew, C.C. The isolation of high molecular weight eukaryotic DNA / C.C. Mathew // Methods molecular biology. N.Y. - 1984. - Vol. 2. - P.31-34.

11. Sánchez-Cuén, J. APOB-100, APOE and CYP7A1 gene polymorphisms in Mexican patients with cholesterol gallstone disease / J. Sánchez-Cuén, M. Aguilar-Medina, E. Arámbula-Meraz [et al.] // World J. Gastroenterol. 2010. - Vol. 16, issue 37. - P.4685-4690.

12. Schlesselman, J. Case-control studies. Design, conduct, analysis / J. Schlesselman. - N.Y., Oxford: Oxford University Press. - 1982. - P.457.

13. Stinton, L.M. Epidemiology of Gallbladder Disease: Cholelithiasis and Cancer / L.M. Stinton, E.A. Shaffer // Gut and Liver. - 2012. - Vol. 6, № 2. - P.172-187.

14. Yoo, E.-H. The prevalence and risk factors for gallstone disease / E.-H. Yoo, S.-Y. Lee // Clin. Chem. Lab. Med. 2009. — Vol. 47, № 7. — P.795-807.

\section{ДЕПРЕССИЯ В НЕВРОЛОГИЧЕСКОЙ ПРАКТИКЕ (на примере болевых синдромов и инсульта)}

ДИНАРА РАВИЛЬЕВНА ТЕРЕГУЛОВА, врач-невроЛог МБУЗ «Городская кЛИническая больнИца № 5», Уфа, Россия, тел. 8-987-249-15-35, e-mail: dinamail@mail.ru МАНСУР АМИРОВИЧ КУТЛУБАЕВ, канд. мед. наук, врач-невролог Республиканской клинической больницы им. Г.Г. Куватова, ассистент кафедры неврологии с курсами нейрохирургиии и медицинской генетики ГБОУ ВПО «Башкирский государственный медицинский университет» Минздрава России, Уфа, Россия, тел. 8-347-228-75-00, e-mail: mansur.kutlubaev@yahoo.com

ЛЕЙЛА РИНАТОВНА АХМАДЕЕВА, Докт. меД. наук, проф. кафедры неврологии с курсами нейрохирургиии и медицинской генетики ГБОУ ВПО «Башкирский государственный медицинский университет» Минздрава России, Уфа, Россия, тел. 8-347-272-56-64, e-mail: la@ufaneuro.org

Реферат. Цель исследования - изучение частоты и коррелятов депрессии у стационарных пациентов с болевыми синдромами и после инсульта. Материал и методы. Исследовано две группы пациентов: 125 с болевыми синдромами и 227 в раннем восстановительном периоде после инсульта. Оценка боли проведена с помощью анкеты-опросника и числовой ранговой шкалы (Numerical Rating Scale, NRS), наличие депрессивных расстройств определялось с помощью Госпитальной шкалы тревоги и депрессии (HADS), шкалы депрессии Бэка, по критериям «Руководства по диагностике и статистике психических расстройств» IV пересмотра (DSMIV). Регистрировались тяжесть инсульта по Шкале Национального института здоровья США (NIHSS) и степень инвалидизации по модифицированной шкале Рэнкина (mRs). Результаты и их обсуждение. Выявлена высокая частота симптомов депрессии в обеих группах пациентов. Признаки клинически выраженной депрессии по шкале HADS наблюдались у 34 (27,2\%) пациентов с болями, а по шкале Бека у 98 (78,4\%) отмечалось наличие депрессивных симптомов. В группе пациентов после инсульта депрессия по критериям DSM-IV была выявлена у $49(27,4 \%)$ пациентов. Выраженность симптомов депрессии была связана с выраженностью болевого синдрома и неврологического дефицита после инсульта. Заключение. Депрессия часто развивается при болевых синдромах и после инсульта. Ее выраженность связана с тяжестью основного заболевания. Развитие депрессии при неврологических заболеваниях, вероятно, приводит к формированию порочного круга: неврологическая симптоматика ведет к ограничению функциональных возможностей и развитию депрессии, а она, в свою очередь, препятствует процессу выздоровления.

Ключевые слова: депрессия, болевой синдром, инсульт. 


\title{
DEPRESSION IN NEUROLOGICAL PRACTICE (in cases of pain syndromes and stroke)
}

DINARA R.TEREGULOVA, neurologist of City Clinical Hospital № 5, Ufa, Russia, tel. 8-987-249-15-35,

e-mail: dinamail@mail.ru

MANSUR A. KUTLUBAEV, Candidate of Medical Science, neurologist of Republican Clinical Hospital, assistant of professor of the Department of neurology, neurosurgery and medical genetics of SBEI HPE «Bashkir State

Medical University» of Russian Ministry of Health, Ufa, Russia, tel. 8-347-228-75-00, e-mail: mansur.kutlubaev@yahoo.com LEILA R. AKHMADEEVA, Doctor of Medical Science, Professor of the Department of neurology, neurosurgery and medical genetics of SBEI HPE «Bashkir State Medical University» of Russian Ministry of Health, Ufa, Russia, tel. 8-347-272-56-64, e-mail: la@ufaneuro.org

\begin{abstract}
Aim. To study the frequency and correlates of depression among inpatients with pain syndromes and after stroke. Material and methods. Two groups of patients were recruited: 125 patients with pain syndromes and 227 patients after stroke. Pain intensity was assessed by the questionnaire and Numerical Rating Scale (NRS), symptoms of depression were estimated using Hospital Anxiety and Depression Scale (HADS), Beck Depression Inventory and criteria of Diagnostic and Statistical Manual of Mental Disorders, $4^{\text {th }}$ edition (DSM-IV). Severity of neurological deficit and disability was assessed by National Institutes of Health Stroke Scale (NIHSS) and modified Rankin Scale (mRs) respectively. Results and discussion. The results showed a high frequency of the symptoms of depression in both groups. In the group of patients with pain syndromes clinically significant depression according to HADS was observed in 34 $(27,2 \%)$ cases, depression according to Beck Depression Inventory was diagnosed in 98 cases $(78,4 \%)$. In the group of patients after stroke, depression according to DSM-IV criteria was detected in $49(27,4 \%)$ patients. The severity of the symptoms of depression correlated with the intensity of pain and severity of neurological deficit after stroke. Conclusions. Depression often develops in patients with pain syndromes and after stroke. Its severity is associated with the severity of the main disorder. The development of depression in neurological disorders is likely to result in the formation of a vicious cycle: neurological symptoms lead to functional limitations and to the development of depression, whilst the latter in turn hampers the recovery process.
\end{abstract}

Key words: depression, pain syndrome, stroke.

$\mathrm{B}$ ведение. В последние десятилетия во всем мире отмечается рост частоты депрессивных расстройств. Распространенность депрессии в общей популяции составляет от 3 до $6 \%$, а среди пациентов, обращающихся за помощью в учреждения общемедицинской сети, клинически очерченные типичные фрормы депрессий выявляются не менее чем в $12-25 \%$ случаев. Выявление депрессивных расстройств является актуальной проблемой, поскольку почти половина больных с депрессиями вообще не обращается за специализированной помощью, а 80\% лечатся у врачей общей практики, предъявляя лишь соматические жалобы. Пациент, приходящий к врачу общего профиля, редко жалуется на снижение настроения, беспокойство, тревогу, утрату чувства удовольствия. Боль - основная жалоба, заставляющая человека обратиться к врачу. Депрессия и боль тесно взаимосвязаны и могут усиливать друг друга, формируя порочный круг: депрессия может быть вызвана болью, а может и сама стать причиной развития хронической боли, а также во многих случаях способствовать хронизации острой боли, возникшей в результате тех или иных причин. Чаще всего хронический болевой синдром является «маской» депрессии [1, 2].

Инсульт - одно из наиболее распространенных заболеваний нервной системы. Он является основной причиной инвалидизации среди взрослых людей. Депрессия после инсульта ухудшает исходы основного заболевания. Ее своевременное лечение помогает улучшить восстановление неврологического десицита [3, 4].

Эпидемиологические данные по распространенности депрессии при отдельных заболеваниях колеблются в довольно широких пределах. Это связано как с разными методами диагностики депрессии (клиническая диагностика, использование различных психометрических методик), так и с разной стадией исследованных заболеваний. Важно отметить и то, что депрессивные расстройства влекут за собой серьезные как медицинские, так и социальные последствия: снижается качество жизни пациентов, ухудшается течение соматических заболеваний и задерживается процесс выздоровления, нарушаются адаптационные возможности человека [5].

Целью данной работы являлось исследование частоты и коррелятов депрессии у пациентов с болевыми синдромами и в раннем восстановительном периоде после инсульта.

Материал и методы. На первом этапе исследования набирались пациенты, находящиеся на стационарном лечении в клинике Башкирского государственного медицинского университета в отделениях неврологического, терапевтического, хирургического, гинекологического профиля. В исследование включались пациенты, имеющие болевой синдром на момент опроса. Всем пациентам, давшим информированное согласие на проведение исследования, предлагалось заполнить опросники на выявление депрессии. Также пациенты заполняли анкету с вопросами для комплексной оценки болевого синдрома, его выраженности по числовой ранговой шкале (Numerical Rating Scale, NRS): пациенты оценивали свои болевые ощущения цифрами от 0 (нет боли) до 10 (максимально возможная боль), локализации боли, наличии боли в течение последних 3 мес. Пациенты оценивали степень ограничения повседневной жизнедеятельности изза боли по таким критериям, как «не ограничивала», 
«ограничивала незначительно», «ограничивала значительно».

Для определения наличия симптомов депрессии у пациентов и степени их выраженности использовались валидизированные в России опросники, которые заполнялись пациентами самостоятельно:

1. Шкала депрессии Бека (Beck Depression Inventory, BDI) - для скрининга и оценки степени тяжести депрессивного состояния [6].

2. Госпитальная шкала тревоги и депрессии (Hospital Anxiety and Depression Scale, HADS) 一 для скрининга и субъективной оценки тревоги и депрессии у пациента [7].

На втором этапе исследования набирались пациенты через 4 нед ( \pm 1 нед) после церебрального инсульта. Критериями исключения были субарахноидальное кровоизлияние без формирования гематомы, грубые нарушения речи и хронические психические нарушения в анамнезе.

Регистрировались тяжесть инсульта по Шкале Национального института здоровья США (NIHSS) и степень инвалидизации по модифицированной шкале Рэнкина (mRs). Тяжесть депрессии оценивалась по HADS. При значениях HADS более 7 пациент осматривался психиатром на предмет наличия депрессии по критериям «Руководства по диагностике и статистике психических расстройств» IV пересмотра (DSM-IV) [8, 9, 10]. Статистическую обработку материала проводили с помощью пакета программ IBM SPSS Statistics 21. Данные представлены в виде средней и стандартного отклонения. Бинарные данные сравнивали с помощью параметра $\mathrm{X}^{2}$, категориальные - с помощью теста Манна - Уитни. Для выявления взаимосвязи между тяжестью депрессии и клиническими параметрами, представленными непрерывными переменными (тяжесть инсульта, выраженность когнитивного дефицита и др.), использовался корреляционный анализ Спирмена [11].

Результаты и их обсуждение. Всего в исследовании приняли участие 352 человека. На первом этапе - 125 человек, из них 46 мужчин $(36,8 \%)$ и 79 женщин $(63,2 \%)$ в возрасте от 16 до 84 лет. Преобладающее число пациентов было в возрастных группах 55-60, 60—65, 70-75 лет. Средний возраст пациентов составил $(53,4 \pm 14,8)$ года.

На момент опроса выраженность болевого синд-

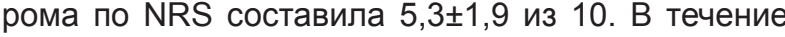
последних трех месяцев более половины пациентов $(64 ; 51,2 \%)$ испытывали боли каждый день, практически треть пациентов (36; 28,8\%) испытывала боль несколько раз в неделю, всего 20 пациентов $(16,0 \%)$ испытывали боли несколько раз в месяц. Средний показатель боли, которую испытывали пациенты за последние 3 мес, составил по NRS $(6,00 \pm 2,12)$ балла из 10, что несколько выше данного показателя на момент опроса. Боль, которую испытывали пациенты в течение последних трех месяцев, в $88 \%$ случаев влияла на повседневную активность пациентов. Эти боли значительно ограничивали повседневную жизнедеятельность у 54 (43,2\%) пациентов, незначительно - у 56 (44,8\%), вовсе не ограничивали у 15 (12,0\%) опрошенных.
По шкале HADS симптомы депрессии выявлены практически у каждого второго пациента: признаки клинически выраженной депрессии наблюдались у 34 (27,2\%) больных, субклинической - у 27 (21,60\%) пациентов. Различия показателей депрессии по шкале HADS у мужчин и женщин статистически не значимы $(p=0,143)$.

По шкале Бека у значительной части пациентов $(98 ; 78,4 \%)$ отмечалось наличие депрессивных симптомов, из них у 35 (28,0\%) имелась легкая депрессия (субдепрессия), у 20 (16\%) умеренная депрессия, у 34 (27,2\%) выраженная депрессия (средней тяжести) и тяжелая депрессия отмечалась у 9 (7,2\%) больных. Различия показателей депрессии у мужчин и женщин статистически не значимы $(p=0,382)$. Различия между уровнями депрессии по шкале Бека в отделениях являются статистически не значимыми $(p=0,404)$.

Из вышеперечисленных данных видно, что показатели уровней депрессии по шкалам Бека и HADS различаются. Возможно, это связано с тем, что чувствительность шкалы Бека для выявления депрессии выше, по данным многих исследований $[12,13]$. У 26 пациентов $(20,80 \%)$ не отмечалось признаков депрессии по обеим шкалам, а у 38 (30,4\%) опрошенных не было выявлено депрессии по шкале HADS, но выявлены симптомы депрессии различной степени тяжести. В основном это были легкие формы депрессии (субдепрессии) у 21 пациента из этой группы (55,3\%). Коэффрициент корреляции между

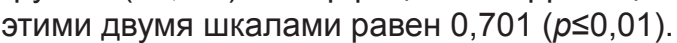

У пациентов, которые в течение последних трех месяцев не испытывали боли, не имели признаков депрессии по шкалам HADS и Бека, была выявлена слабая положительная корреляционная связь между показателями выраженности боли в течение последних трех месяцев и шкалой HADS ( $r=0,2 ; p=0,008)$ и средняя положительная корреляционная связь этого показателя со шкалой депрессии Бека ( $r=0,36$; $p=0,003)$. Корреляционная связь между показателями выраженности боли на момент опроса и этими шкалами была слабее: для шкалы HADS - r=0,06; $p=0,034$; для шкалы Бека $-r=0,15 ; p=0,022$.

На втором этапе исследования депрессия оценивалась у 227 пациентов в раннем восстановительном периоде инсульта, из них 140 мужчин $(61,7 \%)$ и 87 женщин (38,3\%) от 18 до 89 лет, средний возраст - $(63 \pm 13,7)$ года. В выборке преобладали пациенты с нетяжелым неврологическим дефицитом: показатель NIHSS - 2,2 $\pm 2,2 ; \mathrm{mRs}-1,2 \pm 1,2$. У подавляющего большинства пациентов были ишемические инсульты - 194 человека (85,5\%), у $83(36,5 \%$ - в правом каротидном бассейне, у $80(35,5 \%)$ - в левом каротидном бассейне и у 64 (28\%) - в вертебробазилярном бассейне. У 15\% пациентов инсульты были повторные.

Депрессия по критериям DSM-IV была выявлена у $49(27,4 \%)$ пациентов. Во всех случаях речь шла о малом депрессивном эпизоде. Средний пока-

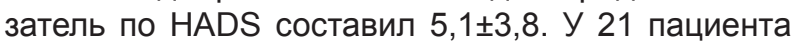
отмечалась клинически выраженная депрессия, у 50 субклинически выраженная депрессия. Сравнительный анализ выявил достоверные различия в вы- 
раженности неврологического десицита по NIHSS $(2 \pm 2,1$ и $2,8 \pm 2,4 ; p=0,026)$ и степени инвалидизации по mRs $(1 \pm 1,2$ и $1,5 \pm 1,3 ; p=0,019))$ у пациентов с депрессией по критериям DSM и без нее. Различий по полу, возрасту, а также по типу инсульта, сосудистому бассейну и наличию когнитивного дефицита по МоСА у пациентов с депрессией и без нее выявлено не было.

Для подтверждения выявленной связи был проведен корреляционный анализ, который выявил достоверно слабую связь между тяжестью неврологического дефицита по NIHSS и mRs ( $r=0,3 ; p=0,0001)$. Связи между возрастом, тяжестью когнитивного дефицита по МоСА и выраженностью депрессии по HADS выявлено не было.

Заключение. Таким образом, депрессия - частое явление при болевых синдромах и после церебрального инсульта. В обоих случаях выраженность депрессии была связана с тяжестью основного патологического процесса (тяжесть неврологического дефицита, в меньшей степени - выраженность боли), что указывает на возможную реактивную природу ее развития. Исходя из полученных данных, можно предположить, что при развитии депрессии при неврологическом заболевании развивается порочный круг: неврологическая симптоматика (боль, парезы, нарушения координации и др.) ведет к ограничению функциональных возможностей и через сложные патофизиологические механизмы приводит к реакции в виде развития симптомов депрессии $[14,15]$. С другой стороны, депрессия усугубляет неврологическую симптоматику. При болевых синдромах она усиливает восприятие боли и способствует ее хронизации за счет таких феноменов, как центральная сенситизация. При инсультах депрессия ухудшает восстановление неврологического дефицита за счет нарушения нейропластичности нейромедиаторных процессов, низкой приверженности к реабилитационным мероприятиям [16]. Разорвать порочный круг можно воздействуя на оба звена: устраняя источник боли (с помощью противовоспалительных средств, миорелаксантов и др.) и проводя реабилитационные меры, с одной стороны, и корригируя явления депрессии с помощью антидепрессантов и психотерапии - с другой. Своевременное выявление депрессии и привлечение к работе с неврологическими больными мультидисциплинарной команды с участием психолога/психотерапевта является важным условием для успешного лечения данной категории пациентов.

\section{ЛИТЕРАТУРА}

1. Смулевич, А.Б. Депрессии в общей медицине / А.Б. Смулевич. - М.: Медицина, 2007. - С.100-107, $191-233$

2. Депрессия в неврологической практике / А.М. Вейн, Т.Г. Вознесенская, В.Л. Голубев, Г.М. Дюкова. - М.: Медицина, 2002. - С.20-30, 66-84.

3. Суслина, З.А. Инсульт: оценка проблемы (15 лет проблемы) / З.А. Суслина, М.А. Пирадов, М.А. Домашенко // Журнал неврологии и психиатрии. - 2014. № 11. - C.5-13.

4. Kutlubaev, M. Part II: predictors of depression after stroke and impact of depression on stroke outcome: an updated systematic review of observational studies / M. Kutlubaev, M. Hackett // Int. J. Stroke. - 2014. № 9. - P.1026-1036.

5. Воробьева, О.В. Клинические особенности депрессии в общемедицинской практике (по результатам программы «Компас») / О.В. Воробьева // Consilium-Medicum. 2004. - T. II, № 6. - C.9-56.

6. An inventory for measuring depression / A. Beck, C. Ward, M. Mendelson [et al.] // Arch. Gen. Psychiatry. — 1961. № 4. - P.61-71.

7. Дьяконов, И.Ф. Психологическая диагностика в практике врача / И.Ф. Дьяконов, Б.В. Овчинников. - СПб.: СпецЛит, 2008. - С.6-54.

8. Using the NIH Stroke Scale to assess stroke patients / J. Spilker, G. Kongable, C. Barch [et al.]; the NINDS rt-PA Stroke Study Group // J. Neurosci. Nurs. - 1997. Vol. 29, № 3. - P.84-92.

9. Rankin, J. Cerebral vascular accidents in patients over the age of 60. II. Prognosis / J. Rankin // Scott. Med. J. 1957. - Vol. 2. - P.15-200.

10. American Psychiatric Association. Diagnostic and Statistical Manual of Mental Disorders (4th edn) (DSMIV). - Washington DC: APA, 1994.

11. Орлов, А.И. Прикладная статистика: учебник / А.И. Орлов. - М.: Экзамен, 2006. - 671 с.

12. Validity of the Beck Depression Inventory, Hospital Anxiety and Depression Scale, SCL-90, and Hamilton Depression Rating Scale as Screening Instruments for Depression in Stroke Patients / I. Aben, F. Verhey, R. Lousberg [et al.] // Psychosomatics. - 2002. Vol. 43. - P.386-393.

13. Furlanettoa, $M$. The Validity of the Beck Depression Inventory - Short form as a screening and diagnostic instrument for moderate and severe depression in medical inpatients / L. Furlanettoa, M. Mendlowiczbc, J. Buenob // J. of Affective Disorders. - 2005. — Vol. 86, № 1. P.87-91.

14. Ахмадеева, Л.Р. Тревожные и депрессивные состояния и их связь с болевым синдромом у пациентов, находящихся на стационарном лечении / Л.Р. Ахмадеева, Д.Р. Терегулова // Проблемы женского здоровья. 2012. - Т. 7, № 2. - С.23-28.

15. Кутлубаев, М.А. Нейроиммунные механизмы в развитии постинсультной депрессии / М.А. Кутлубаев, Л.Р. Ахмадеева // Журнал неврологии и психиатрии. 2013. - T. 113, № 2. - С.76-79.

16. Selective serotonin reuptake inhibitors for stroke recovery: a systematic review and meta-analysis / G. Mead, C. Hsieh, R. Lee [et al.] // Stroke. — 2013. — Vol. 44. P.844-850.

\section{REFERENCES}

1. Smulevich, A.B. Depressii v obschei medicine [Depression in general medicine] / A.B. Smulevich. - M.: Medicina, 2007. - S.100-107, 191-233.

2. Depressiya $v$ nevrologicheskoi praktike [Depession in neurological practice] / A.M. Vein, T.G. Voznesenskaya, V.L. Golubev, G.M. Dyukova. - M.: Medicina, 2002. S. $20-30,66-84$.

3. Suslina, Z.A. Insul't: ocenka problemy (15 let problemy) [Stroke: assessment of the problem (15 years of challenges)]/Z.A. Suslina, M.A. Piradov, M.A. Domashenko // Zhurnal nevrologii i psihiatrii [Journal of Neurology and Psychiatry]. — 2014. — № 11. - S.5-13.

4. Kutlubaev, M. Part II: predictors of depression after stroke and impact of depression on stroke outcome: an updated systematic review of observational studies / M. Kutlubaev, M. Hackett // Int. J. Stroke. - 2014. № 9. - P.1026-1036. 
5. Vorob'eva, O.V. Klinicheskie osobennosti depressii $\checkmark$ obschemedicinskoi praktike (po rezul'tatam programmy «Kompas») [Clinical features of depression in general practice (results of the program «Compass»)] / O.V. Vorob'eva // Consilium-Medicum [Consiliummedicum]. — 2004. - T. II, № 6. - S.9-56.

6. An inventory for measuring depression / A. Beck, C. Ward M. Mendelson [et al.] // Arch. Gen. Psychiatry. — 1961. № 4. - P.61-71.

7. D'yakonov, I.F. Psihologicheskaya diagnostika v praktike vracha [Psychological diagnosis in the practice] / I.F. D'yakonov, B.V. Ovchinnikov. - CPb.: SpecLit, 2008. - S.6-54.

8. Using the NIH Stroke Scale to assess stroke patients / J. Spilker, G. Kongable, C. Barch [et al.]; the NINDS rt-PA Stroke Study Group // J. Neurosci. Nurs. - 1997. Vol. 29, № 3. - P.84-92.

9. Rankin, J. Cerebral vascular accidents in patients over the age of 60. II. Prognosis / J. Rankin // Scott. Med. J. 1957. - Vol. 2. - P.15-200.

10. American Psychiatric Association. Diagnostic and Statistical Manual of Mental Disorders (4th edn) (DSMIV). - Washington DC: APA, 1994.

11. Orlov, A.I. Prikladnaya statistika: uchebnik [Applied Statistics. Tutorial] / A.I. Orlov. - M.: Ekzamen, 2006. - $671 \mathrm{~s}$.

12. Validity of the Beck Depression Inventory, Hospital Anxiety and Depression Scale, SCL-90, and Hamilton
Depression Rating Scale as Screening Instruments for Depression in Stroke Patients / I. Aben, F. Verhey, R. Lousberg [et al.] // Psychosomatics. - 2002. Vol. 43. - P.386-393.

13. Furlanettoa, $M$. The Validity of the Beck Depression Inventory - Short form as a screening and diagnostic instrument for moderate and severe depression in medical inpatients / L. Furlanettoa, M. Mendlowiczbc, J. Buenob // J. of Affective Disorders. - 2005. — Vol. 86, № 1. P.87-91.

14. Ahmadeeva, L.R. Trevozhnye i depressivnye sostoyaniya i ih svyaz' s bolevym sindromom u pacientov, nahodyaschihsya na stacionarnom lechenii [Anxiety and depressive states and their relation to the pain syndrome in hospitalized patients] / L.R. Ahmadeeva, D.R. Teregulova // Problemy zhenskogo zdorov'ya [Problems of women's health]. 2012. - T. 7, № 2. - S.23-28.

15. Kutlubaev, M.A. Neiroimmunnye mehanizmy $v$ razvitii postinsul'tnoi depressii [Neuroimmune mechanisms in the development of poststroke depression] / M.A. Kutlubaev, L.R. Ahmadeeva // Zhurnal nevrologii i psihiatrii [Journal of Neurology and Psychiatry]. — 2013. — T. 113, № 2. S.76-79.

16. Selective serotonin reuptake inhibitors for stroke recovery: a systematic review and meta-analysis / G. Mead, C. Hsieh, R. Lee [et al.] // Stroke. - 2013. — Vol. 44. P.844-850

\section{ПОКАЗАТЕЛИ ЛИПИДНОГО ОБМЕНА ПАЦИЕНТОВ С ИШЕМИЧЕСКОЙ БОЛЕЗНЬЮ СЕРДЦА И КОМОРБИДНОЙ ПАТОЛОГИЕЙ В ЗАВИСИМОСТИ ОТ СТЕПЕНИ СТЕНОЗА СТВОЛА ЛЕВОЙ КОРОНАРНОЙ АРТЕРИИ}

ГУЛЬНАЗ ЗИННУРОВНА ХАЛИМОВА, соискатель кафедры факультетской терапии и кардиологии ГБОУ ВПО «Казанский государственный медицинский университет» Минздрава России, врач-кардиолог отделения кардиологии № 1 Межрегионального клинико-диагностического центра, Казань, Россия, тел. 8-917-225-51-95, e-mail: gulnazm85@mail.ru

АЛЬБЕРТ САРВАРОВИЧ ГАЛЯВИЧ, докт. мед. наук, проф., зав. кафедрой факультетской терапии и кардиологии ГБОУ ВПО «Казанский государственный медицинский университет» Минздрава России, Казань, Россия, тел. 296-16-43, e-mail: agalyavich@mail.ru

МИХАИЛ ВАЛЕНТИНОВИЧ ПАНАСЮК, докт. геогр. наук, проф., ведущий специалист отдела по науке и инновациям Межрегионального клинико-диагностического центра, Казань, Россия, тел. 8-919-639-71-91,

e-mail: mp3719@yandex.ru

Реферат. Цель исследования - изучение липидного обмена пациентов с ишемической болезнью сердца (ИБС) и коморбидной патологией в зависимости от степени стеноза ствола левой коронарной артерии (СЛКА). Материал и методы. В исследование включены 138 человек с диагнозом ИБС, поражением СЛКА более $50 \%$ и сопутствующей гипертонической болезнью. Выделены группы с сахарным диабетом (СД) - 44 пациента и без СД - 94 пациента. Проведен сравнительный анализ показателей между группами и в подгруппах относительно запланированной операции коронарного шунтирования (КШ) и степени стеноза СЛКА. Результаты и их обсуждение. В группе пациентов без СД подгруппы, ожидающие операцию КШ (КШ+) и не ожидающие операцию КШ (КШ-), достоверно различались по показателям «пол», «функциональный класс стенокардии напряжения». В группе пациентов с СД выявлены достоверные различия по показателям холестерина липопротеидов низкой плотности (ЛПНП). Для пациентов без СД выделены подгруппы с относительно высоким $(85,51 \%)$ и низким $(63,68 \%)$ стенозами. Средние значения общего холестерина (OX) и ЛПНП в подгруппах отличались незначительно. В группе пациентов с СД выделены подгруппы со средним стенозом 78,9\% и 60,6\% соответственно, где выявлены достоверные различия по показателям ОХ и ЛПНП. Сравнение подгрупп с меньшим стенозом СЛКА (63,7\% в группе без СД и 60,6\% в группе с СД) достоверные различия по показателям ОХ и ЛПНП не выявило. В подгруппах с большим стенозом (соответственно 85,5\% и 78,9\%) определены достоверные различия по данным показателям. Заключение. Сахарный диабет, степень стеноза СЛКА существенно влияют на показатели липидного обмена пациентов с ИБС и значимым стенозом СЛКА.

Ключевые слова: ствол левой коронарной артерии, ишемическая болезнь сердца, коронарное шунтирование, сахарный диабет. 


\title{
LIPID METABOLISM IN PATIENTS WITH CORONARY ARTERY DISEASE AND COMORBIDITIES DEPENDING ON STENOSIS OF THE LEFT MAIN CORONARY ARTERY
}

GULNAZ Z. KHALIMOVA, candidate for a degree of the Department of faculty therapy and cardiology of SBEI HPE "Kazan State Medical University» of Russian Ministry of Health, cardiologist of cardiology department № 1 of Interregional Clinical Diagnostic Center, Kazan, Russia, tel. 8-917-225-51-95, e-mail: gulnazm85@mail.ru

ALBERT S. GALYAVICH, Doctor of Medical Scienc, Professor, Head of the Department of faculty therapy and cardiology of SBEI HPE «Kazan State Medical University» of Russian Ministry of Health, Kazan, Russia, tel. 296-16-43, e-mail: agalyavich@mail.ru MIKHAIL V. PANASYUK, Doctor of geographic Science, Professor, leading specialist of the Department of science and innovation of Interregional Clinical Diagnostic Center, Kazan, Russia, tel. 8-919-639-71-91, e-mail: mp3719@yandex.ru

\begin{abstract}
Aim. The study of lipid metabolism in patients with coronary heart disease (CHD) and comorbid disorders depending on stenosis of the left main coronary artery (LMCA). Material and methods. 138 people with CHD, defeat of the LMCA more than $50 \%$ and concomitant hypertension were included to the study. We separated groups with diabetes mellitus (DM) - 44 patients and without DM -94 patients. The comparative analysis between the groups and subgroups in order to planned coronary artery bypass surgery (CABG) and the degree of stenosis LMCA was held. Results. In the group without DM, subgroups awaiting CABG surgery (CABG +) and not awaiting CABG surgery (CABG-) differed significantly by sex and functional class of angina. In group with DM was found significant differences in levels of low density lipoprotein cholesterol (LDL). For patients without DM were determined subgroups with a relatively high $(85,51 \%)$ and low stenosis $(63,68 \%)$. The averages of total cholesterol (TC) and LDL differed slightly. In group with DM we had the subgroups with $78,9 \%$ and $60,6 \%$ stenosis respectively, where was showed significant differences. Comparing subgroups with relatively low stenosis of LMCA $(63,7 \%$ in the group without DM and $60,6 \%$ in the group with DM) did not identified significant differences of LDL and TC. In subgroups with relatively high stenosis $(85,5 \%$ and $78,9 \%$ respectively) there were found significant differences. Conclusion. DM, degree of stenosis LMCA significantly affects on lipid metabolism in patients with CHD and a significant stenosis of the LMCA.

Key words: the left main coronary artery, coronary heart disease, coronary artery bypass graft, diabetes mellitus.
\end{abstract}

оражение ствола левой коронарной артерии (СЛКА) является патологией высокого риска, поскольку через этот отдел осуществляется кровоснабжение до 75-100\% миокарда левого желудочка сердца и оценивается как независимый предиктор повышения заболеваемости и смертности пациентов с ишемической болезнью сердца (ИБС) [4]. Диагностическим методом выявления поражения СЛКА является коронарография, согласно результатам которой значимое поражение «незащищенного» СЛКА встречается у 5-7\% пациентов. У $50 \%$ пациентов, получавших медикаментозную терапию, при наличии значимого поражения «незащищенного» СЛКА наблюдается смертность в течение 3 лет [7]. Термин «незащищенный» СЛКА предполагает, что операция аортокоронарного шунтирования (АКШ) ранее не выполнялась или после операции АКШ отсутствуют фрункционирующие шунты в систему левой коронарной артерии [5].

Операция коронарного шунтирования (КШ) является «золотым стандартом» в лечении поражения «незащищенного» СЛКА [8]. Согласно рекомендациям Американской кардиологической ассоциации (АНА) и Американского кардиологического колледжа (АСC), проведение операции КШ показано при стенозе СЛКА более $50 \%$ и наличии стабильной стенокардии напряжения или безболевой ишемии миокарда. Проведение неотложной операции КШ является предпочтительным при сочетании острого коронарного синдрома и выраженного стенозирования СЛКА. Наличие нестабильной стенокардии является независимым предиктором тяжелых сопутствующих сердечных событий [6].

Целью настоящего исследования явилось изучение показателей липидного обмена у пациентов с
ИБС и коморбидной патологией в зависимости от стеноза СЛКА.

Материал и методы. В ходе исследования был проведен ретроспективный анализ историй болезни пациентов с поражением СЛКА (стеноз просвета артерии более $50 \%$ ):

а) оставшихся на консервативной терапии после выявления поражения СЛКА;

б) ожидающих операцию КШ после выявления поражения СЛКА.

Исследование проводилось на основе выборки, в которую были включены 138 человек с диагнозом ИБС и сопутствующей гипертонической болезнью (ГБ). В ходе анализа историй болезни были выделены группы пациентов, страдающие сахарным диабетом (СД) - 44 пациента и без СД - 94 пациента.

Анализ влияния гиполипидемической терапии (вида статина, дозировки) на показатели липидного обмена не проводился в связи с кратковременностью пребывания пациентов в стационаре.

Выявление межгрупповых различий по уровню заданного признака было основано на использовании U-критерия Манна - Уитни. Статистическая обработка полученных данных была проведена с помощью статистического пакета Statsoft Statistica 10. Сравнительный анализ проводился по следующим признакам: возраст, пол, функциональный класс (ФК) стенокардии напряжения 2-4, фрракция выброса (ФВ) по данным эхокардиографии, уровни общего холестерина (OX), холестерина липопротеидов низкой плотности (ЛПНП), холестерина липопротеидов высокой плотности (ЛПВП), триглицеридов (ТГ), глюкозы, креатинина в сыворотке крови.

Были проанализированы данные признаки в группе пациентов без сахарного диабета (94 па- 
циента). Показатели оценивались относительно запланированной операции коронарного шунтирования у пациентов в данной группе. В результате пациенты, ожидающие показанную операцию КШ (КШ+), и пациенты, оставшиеся только на медикаментозном лечении (КШ-), достоверно различались по показателям «пол» (при $p=0,02)$, «функциональный класс стенокардии напряжения» $(p=0,004)$ (табл. 1).

Т а блица 1

Различия между подгруппами КШ+/КШ- в группе ИБС+ГБ по основным анализируемым статистическим показателям

\begin{tabular}{|l|c|c|c|}
\hline Показатель & $\begin{array}{c}\text { Подгруппа } \\
\text { КШ+ }(n=71)\end{array}$ & $\begin{array}{c}\text { Подгруппа } \\
\text { КШ- }(n=23)\end{array}$ & $\begin{array}{c}\text { Значение } p \\
(p<0,05)\end{array}$ \\
\hline Пол, м/ж & $58 / 13$ & $13 / 10$ & 0,02 \\
\hline ФК СН & $3,1 \pm 0,43$ & $2,7 \pm 0,54$ & 0,004 \\
\hline
\end{tabular}

Примечание: КШ - коронарное шунтирование, м/ж мужчины/женщины, ФК СН - функциональный класс стенокардии напряжения, $n-$ количество пациентов, $p-$ уровень достоверности.

В результате сравнительного анализа показателей в группе пациентов с СД (44 пациента) обнаружены достоверные различия в данных группах по показателям ЛПНП (табл. 2).

Таблица 2

Различия между подгруппами КШ+/КШ- в группе ИБС+ГБ+СД по основным анализируемым статистическим показателям

\begin{tabular}{|l|c|c|c|}
\hline Показатель & $\begin{array}{c}\text { Подгруппа } \\
\text { КШ+ }(n=35)\end{array}$ & $\begin{array}{c}\text { Подгруппа } \\
\text { КШ- }(n=9)\end{array}$ & $\begin{array}{c}\text { 3начение } p \\
(p<0,05)\end{array}$ \\
\hline ЛПНП & $3,06 \pm 1,27$ & $4,54 \pm 1,17$ & 0,02 \\
\hline
\end{tabular}

Примечание: КШ - коронарное шунтирование, лПНП холестерин липопротеидов низкой плотности, $n-$ количество пациентов, $p$ - уровень достоверности.

Внутренняя неоднородность групп пациентов с СД и без СД обусловили поиск в их составе подгрупп, имеющих качественные различия по заданному множеству аналитических параметров. Выявление качественного своеобразия однородных подмножеств пациентов в группах с СД и без СД позволило провести более глубокий анализ взаимосвязей и получить результаты, которые не выявлялись на уровне относительно больших внутренне неоднородных групп.

Для решения подобных задач использовались статистические методы классификации и группировки, в частности методы кластер-анализа (кластеризации). Они на основе анализа сходства пациентов по значениям заданных параметров позволили выделить как в группе с СД, так и в группе без СД по две относительно однородные подгруппы пациентов, которые в то же время имели значимые отличия друг от друга.

Результаты классифрикации по показателю стеноза пациентов без СД и с СД (табл. 3, 4) показали, что в обоих случаях имеются устойчивые подгруппы пациентов с относительно высоким и относительно низким процентом стеноза, в которых средние значения различаются на 33-35\%.
Та блица 3

Показатель стеноза по подгруппам (кластерам) пациентов без СД

\begin{tabular}{|l|c|c|}
\hline Показатель & $\begin{array}{c}\text { Среднее значение } \\
\text { в подгруппе } \\
\text { (кластере) 1 }(n=37)\end{array}$ & $\begin{array}{c}\text { Среднее значение } \\
\text { в подгруппе } \\
\text { (кластере) 2 }(n=57)\end{array}$ \\
\hline Стеноз, \% & 85,5 & 63,7 \\
\hline
\end{tabular}

Примечание: $n$ - количество пациентов.

Та блица 4

Показатель стеноза по подгруппам (кластерам) пациентов с СД

\begin{tabular}{|l|c|c|}
\hline Показатель & $\begin{array}{c}\text { Среднее значение } \\
\text { в подгруппе } \\
\text { (кластере) 1 }(n=27)\end{array}$ & $\begin{array}{c}\text { Среднее значение } \\
\text { в подгруппе } \\
\text { (кластере) 2 }(n=17)\end{array}$ \\
\hline Стеноз, \% & 78,9 & 60,6 \\
\hline
\end{tabular}

Примечание: $n$ - количество пациентов.

Была проведена сравнительная оценка липидного профиля (показателей ОХ, ЛПНП) по подгруппам.

Для пациентов без СД выделили подгруппу с относительно высоким стенозом (37 пациентов) и с относительно низким стенозом (57 пациентов) (см. табл. 4). Средние значения ОХ и ЛПНП в подгруппах отличались в целом незначительно. Так, среднее значение ОХ в первой подгруппе составило $(5,83 \pm 1,41)$ ммоль/л, ЛПНП - $(3,76 \pm 1,55)$ ммоль/л. Средний показатель OX во второй подгруппе составил $(5,88 \pm 1,45)$ ммоль/л, а ЛПНП $(3,85 \pm 1,33)$ ммоль/л.

В группе пациентов с СД выделили две подгруппы с относительно высоким стенозом 78,9\% (27 пациентов) и с относительно низким стенозом $60,6 \%$ (17 пациентов). Среднее значение ОХ в первой подгруппе составило $(4,96 \pm 1,36)$ ммоль/л, ЛПНП $(2,85 \pm 1,14)$ ммоль/л. Средний показатель ОХ во второй подгруппе был в 1,3 раза выше, чем в первой, и составил $(6,33 \pm 1,49)$ ммоль/л, показатель ЛПНП был выше в 1,5 раза и составил $(4,19 \pm 1,02)$ ммоль/л. В этих подгруппах были выявлены достоверные $(p<0,05)$ различия по показателям ОX $(p=0,008)$ и ЛПНП $(p=0,007)$.

Был также проведен сравнительный анализ групп пациентов с СД и без СД в зависимости от степени стеноза СЛКА. В результате сравнения подгрупп с меньшим стенозом СЛКА $(63,7 \%$ в группе без СД и 60,6\% в группе с СД) достоверные различия по показателям OX и ЛПНП не были выявлены. Средний показатель ОХ для группы без СД составил $(5,88 \pm 1,45)$ ммоль/л, ЛПНП $(3,85 \pm 1,33)$ ммоль/л. Для группы с СД среднее значение OX - $(6,33 \pm 1,49)$ ммоль/л, ЛПНП $(4,19 \pm 1,02)$ ммоль/л.

По данным сравнительного анализа подгрупп пациентов с большим стенозом (85,5\% в группе без СД и 78,9\% в группе с СД), были выявлены достоверные различия по показателям $\mathrm{OX}(p=0,03)$ и ЛПНП $(p=0,02)$. Средний показатель ОХ для группы без СД составил $(5,83 \pm 1,41)$ ммоль/л, лПНП $(3,76 \pm 1,55)$ ммоль/л. Для группы с СД среднее значение ОХ составило $(4,96 \pm 1,36)$ ммоль/л, ЛПНП $(2,85 \pm 1,14)$ ммоль/л. 
Результаты и их обсуждение. Пациенты со значимым, но некритическим (50-70\%) стенозом СЛКА относятся к подгруппе потенциально низкого риска. Ряд исследований указывает на неплохой прогноз при поражении ствола ЛКА в пределах $50-70 \%$. Операция КШ существенно не увеличивает продолжительность жизни пациентов со стенозированием СЛКА в пределах 50-59\%, независимо от наличия значимого стеноза правой коронарной артерии, до тех пор пока фракция выброса левого желудочка остается в пределах нормы [3].

В нашей работе мы проанализировали выраженность липидных нарушений у пациентов с ИБС, гипертонической болезнью и сахарным диабетом в зависимости от степени стеноза СЛКА $60 \%$ и более. Следует отметить, что опубликованных исследований в этом отношении весьма мало. В одной из работ [1] отмечено, что больные с наличием артериальной гипертензии (АГ) и/или дислипопротеидемии и коронарным атеросклерозом характеризуются более атерогенным липопротеидным профилем по сравнению с больными с фракторами риска ИБС, но без поражения коронарных артерий, при этом достоверные отличия между группами больных с разной степенью выраженности стеноза коронарных артерий отсутствуют.

В другой работе [2] у пациентов было выявлено, что степень изменения показателей липидного обмена у пациентов с ИБС и неудовлетворительным результатом КШ в сроки до года после операции зависит от степени выраженности АГ. Уровни ОХ и холестерина ЛПНП были выше у пациентов с АГ 3-й степени по сравнению с пациентами со 2-й степенью и группой контроля.

По нашим данным, у пациентов с СД II типа уровни ОХ и холестерина ЛПНП значительно ниже при большем стенозе СЛКА по сравнению с пациентами с СД с меньшей степенью стеноза СЛКА и пациентами без сахарного диабета.

\section{Выводы:}

1. Уровень холестерина ЛПНП при наличии сопутствующего СД ниже в случае запланированной операции КШ.

2. Уровень ОХ и ЛПНП не коррелирует со степенью стенозирования СЛКА при наличии сопутствующего СД.

3. Пациенты с СД имеют более низкий уровень ОХ и холестерин ЛПНП при большем стенозе СЛКА по сравнению с группой пациентов без СД.

\section{ЛИТЕРАТУРА}

1. Жук, М.Ю. Показатели атеротромбогенности при сочетании артериальной гипертонии и дислипидемии у больных с разной выраженностью коронарного атеросклероза: автореф. дис. ... канд. мед. наук / М.Ю. Жук. — М., 2004. — URL: http://www.dissercat.com/ content/pokazateli-aterotrombogennosti-pri-sochetaniiarterialnoi-gipertonii-i-dislipidemii-u-bolny-0 (дата обращения: 18.04.2015).

2. Ярков, В.И. Влияние нарушений липидного обмена и тромбоцитарно-сосудистого звена гемостаза на диссрункцию коронарных шунтов у больных ИБС в сочетании с эссенциальной артериальной гипертензией: автореф. дис. ... канд. мед. наук / В.И. Ярков. - Ново- сибирск, 2009. —URL: http://www.dissercat.com/content/ vliyanie-narushenii-lipidnogo-obmena-i-trombotsitarnososudistogo-zvena-gemostaza-na-disfunk (дата обращения: 18.04.2015).

3. Gyenes, G.T. Should all patients with asymptomatic but significant $(>50 \%)$ left main coronary artery stenosis undergo surgical revascularization / G.T. Gyenes, W.A. Ghali // Circulation. — 2008. — Vol. 118. — P.422425.

4. Fajadet, $J$. Current management of left main coronary artery disease / J. Fajadet, A. Chieffo // Oxford Journals Medicine European Heart Journal. — 2011. — Vol. 33. P.36-50.

5. Left main coronary angioplasty: early and late results of 127 acute and elective procedures / J.Jr. O'Keefe, G.O. Hartzler, B.D. Rutherford [et al.] // Am. J. Cardiol. 1989. - Vol. 64. - P.144-147.

6. Left Main Coronary Artery Stenosis: factors predicting cardiac events in patients awaiting coronary surgery / S.S. Virani, C.E. Mendoza, A.C. Ferreira, E. de Marchena // Tex. Heart Inst. J. — 2006. - Vol. 33(1). - P.23-26.

7. Coronary Artery Bypass Graft Surgery vs Percutaneous Interventions in Coronary Revascularization: A Systematic Review / S. Deb, H.C. Wijeysundera, D.T. Ko [et al.] // JAMA. — 2013. — Vol. 310(19). - P.2086-2095.

8. Revascularisation for unprotected left main stem coronary artery stenosis: stenting or surgery / D. Taggart, S. Kaul, W.E. Boden [et al.] // J. Am. Coll. Cardiol. - 2008. Vol. 51. - P.885-892.

\section{REFERENCES}

1. Zhuk, M.Yu. Pokazateli aterotrombogennosti pri sochetanii arterial'noi gipertonii i dislipidemii u bol'nyh s raznoi vyrazhennost'yu koronarnogo ateroskleroza [Indicators of aterothrombogenicity in combination of hypertension and dyslipidemia in patients with varying severity of coronary atherosclerosis]: avtoref. dis. ... kand. med. nauk / M.Yu. Zhuk. - M., 2004. - URL: http://www. dissercat.com/content/pokazateli-aterotrombogennostipri-sochetanii-arterialnoi-gipertonii-i-dislipidemii-u-bolny-0 (data obrascheniya: 18.04.2015).

2. Yarkov, V.I. Vliyanie narushenii lipidnogo obmena i trombocitarno-sosudistogo zvena gemostaza na disfunkciyu koronarnyh shuntov u bol'nyh IBS v sochetanii s essencial'noi arterial'noi gipertenziei [Influence of lipid metabolism and platelet-vascular hemostasis on coronary bypass grafts dysfunction in patients with coronary artery disease in combination with essential arterial hypertension]: avtoref. dis. ... kand. med. nauk / V.I. Yarkov. - Novosibirsk, 2009. - URL: http://www. dissercat.com/content/vliyanie-narushenii-lipidnogoobmena-i-trombotsitarno-sosudistogo-zvena-gemostazana-disfunk (data obrascheniya: 18.04.2015).

3. Gyenes, G.T. Should all patients with asymptomatic but significant $(>50 \%)$ left main coronary artery stenosis undergo surgical revascularization / G.T. Gyenes, W.A. Ghali // Circulation. - 2008. — Vol. 118. — P.422425.

4. Fajadet, J. Current management of left main coronary artery disease / J. Fajadet, A. Chieffo // Oxford Journals Medicine European Heart Journal. — 2011. — Vol. 33. P.36-50.

5. Left main coronary angioplasty: early and late results of 127 acute and elective procedures / J.Jr. O'Keefe, G.O. Hartzler, B.D. Rutherford [et al.] // Am. J. Cardiol. 1989. - Vol. 64. - P.144-147.

6. Left Main Coronary Artery Stenosis: factors predicting cardiac events in patients awaiting coronary surgery / S.S. Virani, C.E. Mendoza, A.C. Ferreira, E. de Marchena // Tex. Heart Inst. J. — 2006. — Vol. 33(1). - P.23-26. 
7. Coronary Artery Bypass Graft Surgery vs Percutaneous Interventions in Coronary Revascularization: A Systematic Review / S. Deb, H.C. Wijeysundera, D.T. Ko [et al.] // JAMA. — 2013. — Vol. 310(19). — P.2086-2095.
8. Revascularisation for unprotected left main stem coronary artery stenosis: stenting or surgery / D. Taggart, S. Kaul, W.E. Boden [et al.] // J. Am. Coll. Cardiol. - 2008. Vol. 51. - P.885-892.

\title{
РЕЗУЛЬТАТЫ ПРИМЕНЕНИЯ МАНИТНО-ИНФРАКРАСНОЙ ЛАЗЕРНОЙ ТЕРАПИИ В КОМПЛЕКСНОМ ЛЕЧЕНИИ БОЛЬНЫХ С ВПЕРВЫЕ ВЫЯВЛЕННЫМ ДЕСТРУКТИВНЫМ ТУБЕРКУЛЕЗОМ ЛЕГКИХ
}

АРКАДИЙ ЛЕЙБОВИЧ ХАНИН, докт. МеД. Наук, проф., зав. кафедрой фтизиопульмонологии ГОУ ДПО «Новокузнецкий государственный институт усовершенствования врачей» Минздрава России, заслуженный врач РФ, Новокузнецк, Россия, тел. 384-345-48-73, 8-903-945-22-52, e-mail: prof.khanin@yandex.ru

ГАЛИНА ВАЦЛАВОВНА ПИЛЬНИК, зам. Главного врача по лечебной работе ГКУЗ КО «Прокопьевский противотуберкулезный диспансер", врач высшей категории, Прокопьевск, Россия, тел. 384-662-62-94, 8-905-068-34-57, e-mail: galinapilnik@yandex.ru

ГАЛИНА ЛЕОНИДОВНА НИКОТИНА, ГЛ. врач ГКУЗ КО «ПрокопьевскИй противотуберкулезный диспансер», врач высшей категории, Прокопьевск, Россия, тел. 384-662-26-14, 8-960-907-67-69

\begin{abstract}
Реферат. Цель исследования - сравнить эффрективность лечения деструктивного, бациллярного туберкулеза легких у впервые выявленных больных, получавших стандартную химиотерапию (XT), и у пациентов, которым на фроне стандартных схем лечения туберкулеза применяли комплекс магнитно-инфракрасной лазерной (МИЛ) терапии. Материал и методы. Основная группа (45 человек) на фоне стандартной химиотерапии получала МИЛ-терапию, группа сравнения (45 человек), получала ХТ и витаминотерапию. Результаты и их обсуждение. Купирование интоксикационного синдрома к концу первого месяца отмечалось у 62,8\% больных основной группы, в 40,6\% случаев у пациентов контрольной группы. Выраженное или умеренное рассасывание инорильтративных изменений к концу второго месяца лечения отмечалось у $53,3 \%$ пациентов в основной группе и у $24,4 \%$ в контрольной группе. Абациллирование мокроты через 3 мес лечения наступило у 82,2\% больных основной группы и лишь у $51,1 \%$ пациентов в контрольной группе. Полости распада через 6 мес лечения были ликвидированы у $57,8 \%$ у больных основной группы и только у $8,8 \%$ у пациентов контрольной группы. Заключение. Применение МИЛ-терапии на проекцию пораженных участков легких усиливает эффекк антибактериальной терапии деструктивного туберкулеза легких за счет многогранного, комплексного воздействия на основные патогенетические механизмы специфического воспаления.
\end{abstract}

Ключевые слова: туберкулез, бактериовыделение, эффективность лечения, магнитно-лазерная терапия, абациллирование, полости распада.

\section{RESULTS OF USING MAGNETIC-INFRARED-LASER THERAPY IN COMPLEX TREATMENT OF PATIENTS WITH NEW-ONSET DESTRUCTIVE PULMONARY TUBERCULOSIS}

ARKADY L. KHANIN, Doctor of Medical Science, Professor, Head of the Department of phthisiopulmonology of SEI APE «Novokuznetsk State Institute of Postgraduate Medical» of Russian Ministry of Health, honoured doctor of the Russian Federation, Novokuznetsk, Russia, tel. 384-345-48-73, 8-903-945-22-52, e-mail: prof.khanin@yandex.ru

GALINA V. PILNIK, deputy chief physician of medical work of SAIH «Prokopevsky TB dispensaries", the highest category doctor, Prokopyevsk, Russia, tel. 384-662-62-94, 8-905-068-34-57, e-mail: galinapilnik@yandex.ru

GALINA L. NICOTINA, chief doctor of SAIH «Prokopevsky TB dispensaries», the highest category doctor, Prokopyevsk, Russia, tel. 384-6-62-26-14, 8-960-907-67-69

\begin{abstract}
Aim. To compare the effectiveness of treatment of destructive, bacillary pulmonary tuberculosis in newonset patients treated with standard chemotherapy and in patients who used complex magnetic-infrared-laser therapy (MIL-therapy) on the background of standard treatment of tuberculosis. Material and methods. The main group of 45 people received MIL-therapy on a background of standard chemotherapy, comparison group, 45 people received chemotherapy and vitamin therapy. Results and discussion. It was found that intoxication syndrome relief by the end of the first month was observed in $62,8 \%$ of patients of the main group, and in $40,6 \%$ of patients in the control group. Expressed or moderate resorption of infiltrative changes by the end of 2 months treatment was observed in $53,3 \%$ of patients in study group, and $24,4 \%$ in control group. Abacillation of mucus after three months of treatment was observed in $82,2 \%$ of patients of main group, and $51,1 \%$ of patients in control group. Cavities of decay were eliminated from $57,8 \%$ in study group and $8,8 \%$ of patients in control group after 6 months of treatment. Conclusion. Application of MIL-therapy on the affected lung's projection enhances the effect of antibiotic treatment of destructive pulmonary tuberculosis due to the multi-faceted, complex effects on the main pathogenetic mechanisms of specific inflammation.
\end{abstract}

Key words: tuberculosis, bacterial excretion, the effectiveness of treatment, magnetic-laser therapy, abacillation, cavities of decay. 
$\mathrm{B}$ ведение. По данным Всемирной организации здравоохранения (ВОЗ), туберкулез (ТБ) остается одной из самых значимых медицинских и социальных проблем в мире. Россия входит в число 22 стран, где зарегистрировано 80\% всех больных ТБ $[10,12,14]$. Особенно напряженная ситуация в Сибирском федеральном округе [8]. Результаты лечения больных ТБ с применением современных стандартов химиотерапии (ХT) остаются неудовлетворительными. Показатель соотношения числа излеченных больных к числу умерших от ТБ составлял в 2013 г. 2,8 к 1 [14]. Одним из путей улучшения результатов лечения является использование химиопрепаратов в сочетании с физическими методами лечения. К сожалению, физиотерапевтические методы недостаточно широко применяются в современной фтизиатрической и пульмонологической клинике, хотя в прошлом физиотерапия входила в арсенал лечения больных ТБ $[6,15]$. В частности, было несколько работ по применению магнитноинфракрасной лазерной терапии (МИЛ-терапия) у больных ТБ [2, 4, 15].

Основанием для применения МИЛ-терапии при ТБ являются полифакторность терапевтического воздействия, которое способствует более полному проявлению синергического механизма саногенеза, что приводит в итоге к ускорению и усилению клинического эффректа терапии. Лечебное воздействие осуществляется одновременно несколькими видами электромагнитных излучений: низкоинтенсивное импульсное инфракрасное, лазерное, широкополосное инфрракрасное излучение, красный свет и магнитное поле, которые воздействуют на один и тот же участок пораженного ТБ легкого. Саногенетическое воздействие лазерного излучения связано с влиянием на биологические системы на всех уровнях организма. На субклеточном уровне происходит образование свободных радикалов, стереохимическая перестройка молекул, увеличение скорости синтеза белка, ДНК, РНК, ускорение созревания коллагена и его предшественников. Под воздействием энергии лазера на клеточном уровне изменяется мембранный потенциал клетки, повышается ее проницаемость, увеличивается синтетическая активность внутриклеточного аппарата. На тканевом уровне изменяется рН межклеточной жидкости, повышается интенсивность микроциркуляции, окислительновосстановительных процессов. Из-за совпадения длины волны лазерного излучения и максимумов спектра поглощения некоторых биомолекул происходит его избирательное поглощение тканями. Инфракрасное лазерное излучение поглощается преимущественно молекулами нуклеиновых кислот, кислорода, а излучение гелий-неонового лазера молекулами ДНК, цитохромоксидазы, цитохрома С, каталазы, пероксидазы и глютатиона. Избирательная активность белоксинтетического аппарата клеточного ядра, дыхательной цепи, антиоксидантной системы приводит к усилению потребления кислорода и увеличению внутриклеточного окисления органических веществ, стимулирует гликолиз, липолиз и окислительное фосфолирование клеток. Это способствует предотвращению каскадного накопления провоспалительных веществ в пораженном органе. Под влиянием воздействия лазерного излучения на ткани легкого происходят фазовые изменения локального кровотока. Увеличение проницаемости альвеолокапиллярной мембраны способствует разрешению инфильтративно-экссудативных процессов в альвеолах и интерстиции легкого. Отмечается стимулирование активности макрофагов и нейроэндокринных телец. Образующиеся при этом продукты обмена белков, аминокислот действуют как эндогенные индукторы репаративных и регенеративных процессов в легких и бронхах, активируют метаболизм выстилающих их поверхность клеток. Постоянное магнитное поле способствует электрической диссоциации ионов в тканях и увеличивает диэлектрическую проницаемость биополимеров. Сочетанное использование этих факторов обеспечивает значительную глубину проникновения электромагнитных колебаний, оказывая воздействие на более глубоко расположенные патологические процессы в легких [5, 7, 9, 11, 13].

Методика проведения МИЛ-терапии при ограниченных и распространенных поражениях туберкулезом легких была стандартной [11]. МИЛ-терапия выполнялась на аппарате «Рикта-04/4» в режиме лазерного воздействия с частотой 5-50 Гц. Средняя мощность инфракрасного светодиодного излучения составила $(60 \pm 30)$ мВт, воздействие постоянным магнитным полем индукцией - $(35 \pm 10)$ мТл по $1-5$ мин на пораженные зоны легких контактным способом наложения излучателя аппарата. На курс 30-40 процедур, ежедневно.

Процедуры МИЛ-терапии рекомендуется проводить после подбора антибактериальной терапии в одно и то же время суток на протяжении всего курса фризиотерапии, поскольку основные реакции организма носят ритмичный, фазовый характер. Длительность лечебных процедур может варьировать в зависимости от применяемых способов МИЛтерапии, но не должна превышать 15 мин в день.

Цель исследования - сравнить эффективность лечения деструктивного бациллярного туберкулеза легких у впервые выявленных больных, получавших стандартную химиотерапию, и у пациентов, которым на фоне стандартных схем лечения туберкулеза применяли комплекс магнитно-инфракрасной лазерной терапии (МИЛ-терапии).

Материал и методы. Проведено рандомизированное контролируемое исследование по единому протоколу 90 больных туберкулезом (ТБ) (49 мужчин и 41 женщина) возрасте от 20 до 60 лет. При отборе больных предусматривалось следующее: курабельность больного (срок дожития не должен быть меньше срока лечения ТБ), отсутствие отягощающей сопутствующей патологии в стадии декомпенсации, социальная адаптация больных. В частности, в исследование не включались пациенты, страдающие алкогольной и наркотической зависимостью, которые не способны выполнять больничный режим и назначенную терапию.

Анализ проводился на базе отделения для лечения больных с деструктивными формами ТБ легких. У 49 больных процесс был односторонним, 
у 41 - двусторонним. В основную группу входили пациенты с впервые выявленным туберкулезом легких в фазе распада и бактериовыделением по микроскопии мазка мокроты. Основная группа (45 человек) на фоне стандартной химиотерапии (ХТ) получала МИЛ-терапию, группа сравнения (контрольная, 45 человек), получала XТ и витаминотерапию в соответствии с современными протоколами лечения больных ТБ [10]. Все пациенты были бактериовыделителями с сохраненной лекарственной чувствительностью к препаратам первого ряда. Отбор пациентов в группы происходил следующим образом: при поступлении в отделение больной, отвечающий приведенным критериям, согласно условной очереди зачислялся в основную группу, следующий поступивший больной - в группу сравнения. Отбор осуществлялся на основании разработанного алгоритма независимыми специалистами, которые не участвовали в разработке методики терапии. Каждый пациент заполнял бланк информированного согласия, что соответствовало международным и российским законодательным актам о юридических и этических принципах клинических исследований.

При поступлении в стационар всем пациентам проводилось комплексное клиникорентгенологическое и лабораторное обследование с включением методов, необходимых для верифрикации диагноза и динамического наблюдения за течением процесса и состоянием больного. Особое внимание уделялось жалобам, предъявляемым больными. По общепринятым критериям ежедневно проводилась оценка общих и легочных симптомов. В еженедельном режиме исследовали показатели периферической крови (СОЭ, лейкоцитоз, количество палочкоядерных нейтрофилов, лимфоцитов и моноцитов). Исходно и в ежемесячном режиме - биохимическое исследование крови. Каждому пациенту проводилось трехкратное (три дня подряд) исследование мокроты на кислотоустойчивые микобактерии (КУМ) методом прямой бактериоскопии, люминесцентным методом и два - методом посева мокроты на МБТ (среда Левенштейна - Йенсена), а также определение ДНК МБТ и лекарственной чувствительности к рифрампицину на аппарате Gene-Xpert.
Рентгенологическое исследование органов грудной полости включало обзорную рентгенографию в прямой и боковых проекциях, прицельные снимки и томографию легких. При необходимости проводилась спиральная компьютерная томография (СКТ) органов грудной клетки.

В стандартной химиотерапии использовались основные противотуберкулезные препараты первого ряда (изониазид, рифрампицин, пиразинамид, этамбутол). Все пациенты находились на стационарном лечении. Эффрективность лечения оценивали через 1, 3, 6 мес от начала лечения по скорости ликвидации жалоб, купирования синдрома интоксикации, ликвидации легочных симптомов, нормализации аускультативной картины, лабораторных, инструментальных, функциональных данных, а также по прекращению бактериовыделения, рассасыванию инфильтративных изменений в легких и закрытию полостей распада. Компьютерная обработка результатов проводилась с использованием статистических пакетов «Биостат» и «IBM SPSS Statistics 19». Для оценки различия групп применялся критерий Крускала - Уоллиса для непараметрических данных, по качественным признакам различия оценивались с использованием критерия $X^{2}$. Основную группу сравнивали с контрольной группой. Критический уровень значимости принимался равным 0,05.

Результаты и их обсуждение. Как видно из представленных данных (таблица), опытная группа и группа сравнения не имели существенных различий по формам ТБ, количеству больных с бактериовыделением и полостям распада. Не было различий и по полу и возрасту.

Динамику результативности лечения оценивали в хронологическом порядке: через 1 мес - интоксикационный синдром, через 2 мес - рассасывание инфильтрации по рентгенологическим данным, через 3 мес - абациллирование по мазку мокроты и посеву, через 6 мес - закрытие полстей распада по рентгенологической картине. Купирование интоксикационного синдрома к концу первого месяца отмечалось у 22 из 35 больных (62,8\%) основной группы и у 13 пациентов из 32 (40,6\%) контрольной группы ( $\left.\chi^{2}-14,87 ; p>0,05\right)$.

Выраженное или умеренное рассасывание инфильтративных изменений к концу второго месяца

Структура клинических форм туберкулеза легких у исследуемых групп больных

\begin{tabular}{|l|c|c|c|c|c|}
\hline \multirow{2}{*}{\multicolumn{1}{|c|}{ Клинические формы туберкулеза }} & \multicolumn{2}{|c|}{ Основная группа } & \multicolumn{2}{c|}{ Группа контроля } & \multirow{2}{*}{$p$} \\
\cline { 2 - 6 } & Абс. & $\%$ & Абс. & $\%$ & 0,525 \\
\hline Инфильтративный & 18 & 40 & 22 & 48,8 & - \\
\hline В том числе с МБТ+ & 18 & 100 & 22 & 100 & - \\
\hline В том числе с распадом & 18 & 100 & 22 & 100 & 0,832 \\
\hline Диссеминированный & 21 & 46,7 & 19 & 42,2 & - \\
\hline В том числе с МБТ+ & 21 & 100 & 19 & 100 & - \\
\hline В том числе с распадом & 21 & 100 & 19 & 100 & 0,737 \\
\hline Казеозная пневмония & 6 & 13,3 & 4 & 8,9 & - \\
\hline В том числе с МБТ+ & 6 & 100 & 4 & 100 & - \\
\hline В том числе с распадом & 6 & 100 & 4 & 100 & - \\
\hline Всего & 45 & 100 & 45 & 100 & - \\
\hline Всего с МБТ+ & 45 & 100 & 45 & 100 & - \\
\hline Всего с распадом & 45 & 100 & 45 & 100 & - \\
\hline
\end{tabular}


лечения (60 доз ХТ) отмечалось у 24 пациентов $(53,3 \%)$ в основной группе и у $11(24,4 \%)$ в контрольной группе $\left(x^{2}-6,732 ; p<0,05\right)$.

Абациллирование мокроты через 3 мес лечения (90 доз по первому режиму химиотерапии) наступило у $37(82,2 \%)$ больных основной группы и лишь у $23(51,1 \%)$ пациентов в контрольной группе, $\left(\mathrm{X}^{2}-8,45 ; p<0,05\right)$. По основному критерию эффрективности - закрытию полостей распада - через 6 мес лечения отмечалось существенное различие в группах. Полости распада были ликвидированы у $26(57,8 \%)$ больных основной группы и только у 4 $(8,8 \%)$ пациентов контрольной группы $\left(x^{2}-22,05\right.$; $p<0,05)$.

\section{Выводы:}

1. Применение МИЛ-терапии на проекцию пораженных участков легких усиливает эфффект антибактериальной терапии деструктивного туберкулеза легких за счет многогранного, комплексного воздействия на основные патогенетические механизмы специфического воспаления.

2. Через месяц комплексной терапии синдром воспалительной интоксикации был ликвидирован у $62,8 \%$ больных, а в группе сравнения он сохранялся у $59,4 \%$ пациентов.

3. Комплексное лечение с применением МИЛтерапии позволяет добиться абациллирования у $82,2 \%$ больных через 3 мес терапии, а в группе сравнения - лишь у 51,1\% пациентов.

4. Назначение МИЛ-терапии существенно повышает эфффективность лечения по такому ключевому критерию, как закрытие полостей распада. Через 6 мес терапии у пациентов с впервые выявленным деструктивным туберкулезом легких полости были ликвидированы у 57,8\% пациентов опытной и лишь у 8,8\% больных в группе сравнения.

\section{ЛИТЕРАТУРА}

1. Васильев, И.Г. Результаты комплексного лечения хронического деструктивного туберкулеза легких с включением в схему МИЛ-терапии / И.Г. Васильев // Актуальные вопросы туберкулеза и других гранулематозных заболеваний: сб. материалов науч.-практ. конф. молодых ученых. - М., 2001. - C.148-149.

2. Васильев, А.П. Клинический эфрфект низкоинтенсивного лазерного излучения как результат формирования адаптации организма / А.П. Васильев, Н.Н. Стрельцова, М.А. Секисова // Вопросы курортной фризиотерапии и лечебной физкультуры. - 1999. № 4. - C.49-51.

3. Грязнова, Д.А. Эффрективность электромагнитного излучения крайне высокой частоты в комплексной терапии больных туберкулезом легких / Д.А. Грязнова, А.А. Позолотин, С.П. Ханина // Проблемы туберкулеза. -1999 . - № 4. - С.40-42.

4. Левченко, Г.И. Физиотерапия в лечении туберкулеза легких / Г.И. Левченко // Военно-медицинский журнал. - 2002. — № 5. - С.49-51.

5. Левашов, А.Н. Влияние диодного излучения с длиной волны 470 нм на эффективность лечения больных туберкулезом легких / А.Н. Левашов, В.В. Кирьянова, Т.И. Виноградова // Физиотерапия, бальнеология, реабилитация. - 2008. — № 4. - С.15-18.
6. Ломанченков, В.Д. Физиотерапия при туберкулезе легких / В.Д. Ломанченков, А.К. Стрелис. - М.: Медицина, 2000. $-136 \mathrm{c}$

7. Лазеротерапия в комплексном лечении туберкулеза легких у подростков: пособие для врачей / Е.С. Овсянкина, В.Г. Добкин, В.А. Фирсова [и др.] // Проблемы туберкулеза и болезней легких. - 2005. - № 1. C.56-61.

8. Основные показатели противотуберкулезной деятельности в Сибирском и Дальневосточном федеральных округах / О.В. Ревякина, Т.В. Алексеева, Г.С. Мурашкина [и др.]. - Новосибирск, 2012. - 87 с.

9. Пармон, Э.М. Комбинированное низкоинтенсивное лазерное излучение при туберкулезе почек / Э.М. Пармон, В.С. Борщевский, В.С. Камышников // Проблемы туберкулеза и болезней легких. - 2003. - № 6. С.28-33.

10. Фтизиатрия: национальное руководство / под ред. М.И. Перельмана. - М.: ГЭОТАР-Медиа, 2007. $512 \mathrm{c}$.

11. Физиотерапия: национальное руководство / под ред. Г.Н. Пономаренко. - М.: ГЭОТАР-Медиа, 2009. $864 \mathrm{c}$.

12. Ханин, А.Л. Влияние медико-социальных фракторов риска на эффеективность лечения впервые выявленных больных туберкулезом / А.Л. Ханин, С.А. Долгих // Coциально значимые болезни: сб. материалов Междунар. науч.-практ. конф. - Кемерово, 2004. - С.55-57.

13. Частная фризиотерапия: учеб. пособие / под ред. Г.Н. Пономаренко. - М.: Медицина, 2005. - 744 с.

14. Шилова, М.В. Туберкулез в России в 2012-2013 гг. / М.В. Шилова. - М., 2014. - 244 с.

15. Gosselink, R. Phusioterapy / R. Gosselink, E. Hautmeyers // European Resp. Monograph. — 2000. — Vol. 5, № 13. P.70-89.

\section{REFERENCES}

1. Vasil'ev, I.G. Rezul'taty kompleksnogo lecheniya hronicheskogo destruktivnogo tuberkuleza legkih $s$ vklyucheniem $v$ shemu MIL-terapii [Results of treatment of chronic destructive pulmonary tuberculosis with the inclusion in the scheme of MIL-therapy] / I.G. Vasil'ev // Aktual'nye voprosy tuberkuleza i drugih granulematoznyh zabolevanii: sb. materialov nauch.-prakt. konf. molodyh uchenyh [Actual problems of tuberculosis and other granulomatous diseases: collection of materials of scientific and practical conference of young scientists]. M., 2001. - S.148-149.

2. Vasil'ev, A.P. Klinicheskii effekt nizkointensivnogo lazernogo izlucheniya kak rezul'tat formirovaniya adaptacii organizma [The clinical effect of low-intensity laser radiation as a result of the formation of the organism adaptation] / A.P. Vasil'ev, H.H. Strel'cova, M.A. Sekisova // Voprosy kurortnoi fizioterapii i lechebnoi fizkul'tury [Questions of resort physiotherapy and medical physical culture]. - 1999. — № 4. - S.49-51.

3. Gryaznova, D.A. Effektivnost' elektromagnitnogo izlucheniya kraine vysokoi chastoty v kompleksnoi terapii bol'nyh tuberkulezom legkih [The effectiveness of the electromagnetic radiation of extremely high frequency in the treatment of patients with pulmonary tuberculosis] / D.A. Gryaznova, A.A. Pozolotin, S.P. Hanina // Problemy tuberkuleza [Problems of tuberculosis]. - 1999. № 4. $-\mathrm{S} .40-42$.

4. Levchenko, G.I. Fizioterapiya v lechenii tuberkuleza legkih [Physiotherapy in the treatment of pulmonary tuberculosis] / G.I. Levchenko // Voenno-medicinskii zhurnal [Military Medical Journal]. — 2002. — № 5. — S.49-51. 
5. Levashov, A.N. Vliyanie diodnogo izlucheniya s dlinoi volny $470 \mathrm{~nm}$ na effektivnost' lecheniya bol'nyh tuberkulezom legkih [Effect of diode radiation with a wavelength of 470 $\mathrm{nm}$ on the effectiveness of treatment of patients with pulmonary tuberculosis] / A.N. Levashov, V.V. Kir'yanova, T.I. Vinogradova // Fizioterapiya, bal'neologiya, reabilitaciya [Physiotherapy, balneology, rehabilitation]. — 2008. № 4. $-\mathrm{S} .15-18$.

6. Lomanchenkov, V.D. Fizioterapiya pri tuberkuleze legkih [Physiotherapy with pulmonary tuberculosis] / V.D. Lomanchenkov, A.K. Strelis. - M.: Medicina, 2000. - $136 \mathrm{~s}$.

7. Lazeroterapiya $\vee$ kompleksnom lechenii tuberkuleza legkih u podrostkov: posobie dlya vrachei [Laser therapy in the complex treatment of pulmonary tuberculosis in adolescents: A Manual for Physicians] / E.S. Ovsyankina, V.G. Dobkin, V.A. Firsova [i dr.] // Problemy tuberkuleza i boleznei legkih [Problems of tuberculosis and lung diseases]. - 2005. — № 1. - S.56-61.

8. Osnovnye pokazateli protivotuberkuleznoi deyatel'nosti v Sibirskom i Dal'nevostochnom federal'nyh okrugah [Key indicators of TB activities in the Siberian and Far Eastern Federal Districts] / O.V. Revyakina, T.V. Alekseeva, G.S. Murashkina [i dr.]. — Novosibirsk, 2012. — 87 s.

9. Parmon, E.M. Kombinirovannoe nizkointensivnoe lazernoe izluchenie pri tuberkuleze pochek [Combined low-intensity laser radiation when renal tuberculosis] / E.M. Parmon,
V.S. Borschevskii, V.S. Kamyshnikov // Problemy tuberkuleza i boleznei legkih [Problems of tuberculosis and lung diseases]. - 2003. - № 6. - S.28-33.

10. Ftiziatriya: nacional'noe rukovodstvo [Physiotherapy: national leadership] / pod red. M.I. Perel'mana. - M.: GEOTAR-Media, 2007. - $512 \mathrm{~s}$.

11. Fizioterapiya: nacional'noe rukovodstvo [Physiotherapy: national leadership] / pod red. G.N. Ponomarenko. - M.: GEOTAR-Media, 2009. - $864 \mathrm{~s}$.

12. Hanin, A.L. Vliyanie mediko-social'nyh faktorov riska na effektivnost' lecheniya vpervye vyyavlennyh bol'nyh tuberkulezom [Effect of medical and social risk factors on the effectiveness of the treatment of newly diagnosed TB patients] / A.L. Hanin, S.A. Dolgih // Social'no znachimye bolezni: cb. materialov Mezhdunar. nauch.-prakt. konf. [Social significant diseases: Proc. International scientific-practical conference]. - Kemerovo, 2004. S.55-57.

13. Chastnaya fizioterapiya: ucheb. posobie [Private physiotherapy: textbook] / pod red. G.N. Ponomarenko. M.: Medicina, 2005. - $744 \mathrm{~s}$.

14. Shilova, M.V. Tuberkulez v Rossii v 2012-2013 gg. [Tuberculosis in Russia in 2012-2013] / M.V. Shilova. M., 2014. - $244 \mathrm{~s}$.

15. Gosselink, R. Phusioterapy/R. Gosselink, E. Hautmeyers // European Resp. Monograph. — 2000. — Vol. 5, № 13. P.70-89. 


\title{
СОСТОЯНИЕ ИНВАЛИДНОСТИ НАСЕЛЕНИЯ ГОРОДА КАЗАНИ ЗА 1995-2011 ГОДЫ \\ НУРИХАН НУРИСЛАМОВИЧ ШАМСИЯРОВ, канд. мед. наук, заслуженный врач РТ, зам. директора
} по организационно-методической работе ООО «Медицинский диагностический центр», Казань, Россия, тел. +7(927)-442-78-70, e-mail: kybm@mail.ru

АФГАТ НАБИУЛЛОВИЧ ГАЛИУЛЛИН, докт. мед. наук, проф. кафедры менеджмента в здравоохранении ГБОУ ВПО «Казанский государственный медицинский университет» Минздрава России, Казань, Россия, тел. +7(987)296-87-64, e-mail: kybm@mail.ru

Реферат. Цель исследования - представить данные об инвалидности населения г. Казани. Материал и методы. Показана распространенность и структура первичного выхода на инвалидность взрослого населения и лиц трудоспособного возраста. Результаты и их обсуждение. За 1995-2011 гг. даны сведения о наличии роста первичного выхода на инвалидность в 2005 г. до 172,5ะ0,01 (на 1000 населения) по причине увеличения болезней системы кровообращения и органов дыхания, о существенном снижении инвалидности среди населения г. Казани до 65,7士0,008 (на 1000 населения), произошедшего в 2011 г. Приведены сведения о причинах роста и снижения уровней инвалидности в различные периоды наблюдения. Снижение показателей инвалидности произошло за счет уменьшения частоты возникновения случаев болезней костно-мышечной системы $(90,6 \%)$, нервной системы $(60,7 \%)$, глаза $(59,6 \%)$, системы кровообращения $(38,4 \%)$, пищеварения $(31,3 \%)$, злокачественных новообразований $(27,0 \%)$, прогностический коэффрициент снижения первичного выхода на инвалидность до 2016 г. составит 37,3\%. Заключение. Данные, полученные в результате проведенного исследования, рекомендовано использовать для прогнозирования инвалидности, планирования лечебно-профилактических и реабилитационных мероприятий.

Ключевые слова: выход на инвалидность, инвалидность, заболеваемость, структура, динамика.

\section{STATE DISABILITY POPULATION CITY OF KAZAN IN 1995-2011}

NURIKHAN N. SHAMSIYAROV, Candidate of Medical Science, Honored doctor of the Republic of Tatarstan, deputy director of the organizational and methodical work of ICC, Kazan, Russia, tel. +7(927)-442-78-70, e-mail:kybm@mail.ru

AFGAT N. GALIULLIN, Doctor of Medical Science, Professor of the Departmen of health management of SBEI HPE «Kazan State Medical University» of Russia Ministry of Health, Kazan, Russia, tel. +7(987)296-87-64, e-mail: kybm@mail.ru

\begin{abstract}
Aim. Provide data on disability population of the city of Kazan. Material and methods. It shows the extent and structure of primary disability of the adult population and persons of working age. Results and discussion. For the 1995-2011 biennium. are given information about the presence of growth primary disability in 2005 to $172,5 \pm 0,01$ per 1,000 population due to the increase of diseases of the circulatory system and respiratory system, a significant reduction of disability in the population of the city of Kazan to $65,7 \pm 0,008$ (1,000 of the population) occurred in 2011 . The information about the reasons for the growth and reduce the levels of disability in the different periods of observation. The decrease in disability due to a decrease in the incidence of cases of diseases of the musculoskeletal system $(90,6 \%)$, nervous system $(60,7 \%)$, eyes $(59,6 \%)$, circulatory system $(38,4 \%)$, digestive $(31,3 \%)$, malignant neoplasms $(27,0 \%)$, a prognostic factor decrease of primary disability until 2016 will amount to $37,3 \%$. Conclusion. The data obtained as a result of the study, it is recommended to use for predicting disability, planning treatment and prevention and rehabilitation measures.
\end{abstract}

Key words: primary exit to disability, disability, incidence, structure, dynamics.

И звестно, что инвалидность населения является актуальной проблемой не только для органов здравоохранения и социальной защиты, но и для исполнительных и законодательных органов всех уровней $[2,3,8]$. Последнее десятилетие XX в. и первые годы XXI столетия характеризуются ростом общего числа инвалидов, состоящих на учете в органах социального обеспечения. Значительный рост объясняется реальным фрактическим увеличением численности инвалидов и надлежащим статистическим учетом органами социальной защиты $[8,10]$.
Установлено, что показатели инвалидности существенно зависят от целого ряда факторов, куда относятся состояние здоровья нации, система здравоохранения, экологическая обстановка, исторические условия и ряд политических причин и, конечно же, социально-экономические условия жизни населения. Перечисленные фракторы в российском обществе в определенной степени имеют негативную направленность и определяют значительное распространение инвалидности. По распространенности инвалидности судят о состоянии здоровья населения [1-9]. 
В целях изучения динамики распространенности инвалидности нами была изучена ее структура в г. Казани в сравнении с Республикой Татарстан. Распределение числа инвалидов по категориям в г. Казани и в сравнении с данными по РТ на 01.01.2012 г. представлено в табл. 1.

Общее число инвалидов, проживающих в г. Казани, составляет более 1/3 от общего числа инвалидов Республики Татарстан. Преобладающее число инвалидов составили инвалиды 2-й группы (43,5\%), несколько меньше - 1-й группы (22,4\%); в Республике Татарстан - 40,8\% и 24,4\% соответственно. Дети-инвалиды до 18 лет составили 3,6\% (или 4101 ребенок) в Казани и 4,0\% (или 15138 детей) в Республике Татарстан.

Динамика изучения коэффрициента первичной инвалидизации (КПИ) взрослого населения г. Казани с 1995 по 2009 г. заметных отклонений не обнару-

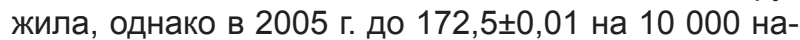
селения был зарегистрирован бурный подъем преимущественно болезней системы кровообращения и несколько меньше - болезней органов дыхания, пищеварения, костно-мышечной системы и соединительной ткани. К 2011 г. произошло сни-

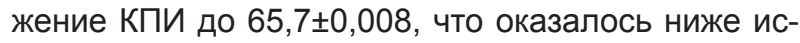

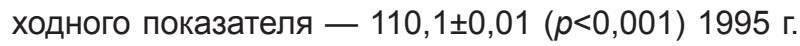
на $28,4 \%$; идентичная динамика прослеживалась и в РТ. КПИ взрослого населения по всем болезням в 1995-2011 гг. сведены в табл. 2 и рис. 1.

Уменьшение КПИ в анализируемом периоде произошло за счет снижения количества следующих болезней: туберкулеза - на 44,0\%, психических расстройств - на 38,8\%, болезней эндокринной системы - на 40,0\%, нервной системы - на 60,7\%, болезни глаза - на 59,6\%, системы кровообращения - на 38,4\%, органов дыхания - на 61,2\%, пищеварения - на 31,3\%. Рост КПИ был зарегистрирован по злокачественным новообразованиям на 27,0\%, болезням костно-мышечной системы - на 90,6\%.

В структуре первичного выхода на инвалидность взрослого населения г. Казани в 2011 г. наибольший удельный вес занимают болезни системы кровообращения $(41,9 \%)$ и новообразования $(20,3 \%)$, а наименьший - болезни эндокринной системы (1,9\%) (рuс. 2).

Первые шесть ранговых мест также занимают болезни системы кровообращения, новообразования, травмы и отравления, болезни костномышечной системы, психические расстройства и болезни нервной системы. Вследствие снижения удельного веса болезней глаз инвалидность от этих заболеваний занимает 10-е место, а болезни органов дыхания - 9-е, 7-е место по праву принадлежит туберкулезу. Структура первичного выхода на инвалидность лиц трудоспособного возраста в 2011 г. мало отличалась от структуры взрослого населения (рис. 3).

Показатели первичного выхода на инвалидность среди взрослого населения снизились с 110,1 случая на 10 тыс. населения в 1995 г. до 65,7 случая в 2011 г. В это же время произошло увеличение коэффиццента инвалидности этого контингента по причине болезней костно-мышечной системы и соединительной ткани за наблюдаемый период с 3,2 до 6,6 $(90,6 \%)$ случая на 10 тыс. населения соответственно, а также злокачественными новообразованиями на $27,0 \%$. Первичный выход на инвалидность взрослого населения имел тенденцию к снижению с 1995 г. по большинству заболеваний с большим подъемом в 2005 г., преимущественно по болезням системы кровообращения.

Проведенный нами прогноз развития первичного выхода на инвалидность до 2016 г. показал, что этот коэффрициент за этот период снизится на $37,3 \%$.

Та блица 1

Численность инвалидов по категориям в Казани и РТ по состоянию на 01.01.2012 г.

\begin{tabular}{|c|c|c|c|c|}
\hline \multirow{2}{*}{ Категории инвалидов } & \multicolumn{2}{|c|}{ г. Казань } & \multicolumn{2}{|c|}{ Республика Татарстан } \\
\hline & Кол-во & $\%$ & Кол-во & $\%$ \\
\hline $\begin{array}{l}\text { Инвалиды войны (в том числе военнослужащие, получившие травмы } \\
\text { при исполнении служебных обязанностей) }\end{array}$ & 1854 & 1,6 & 5391 & 1,4 \\
\hline Ветераны боевых действий & 5932 & 5,2 & 25730 & 6,8 \\
\hline Участники Великой Отечественной войны (имеющие группу инвалидности) & 3432 & 3,1 & 9940 & 2,6 \\
\hline Участники Великой Отечественной войны (не имеющие группу инвалидности) & 46 & 0,1 & 95 & 0,03 \\
\hline Лица, награжденные знаком «Житель блокадного Ленинграда» & 228 & 0,2 & 341 & 0,09 \\
\hline $\begin{array}{l}\text { Военнослужащие последнего военного призыва (не имеющие группу инвалид- } \\
\text { ности) }\end{array}$ & 218 & 0,2 & 566 & 0,1 \\
\hline Бывшие несовершеннолетние узники & 84 & 0,1 & 188 & 0,05 \\
\hline Бывшие несовершеннолетние узники, ставшие инвалидами & 59 & 0,1 & 128 & 0,03 \\
\hline $\begin{array}{l}\text { Члены семей погибших (умерших) инвалидов войны, участников Великой } \\
\text { Отечественной войны и ветеранов боевых действий }\end{array}$ & 4215 & 3,7 & 18276 & 4,8 \\
\hline Инвалиды (3-й степени) 1-й группы & 16684 & 14,8 & 51381 & 13,6 \\
\hline Инвалиды (2-й степени) 2-й группы & 48963 & 43,5 & 154350 & 40,8 \\
\hline Инвалиды (1-й степени) 3-й группы & 25172 & 22,4 & 92399 & 24,4 \\
\hline Дети-инвалиды (в возрасте до 18 лет) & 4101 & 3,6 & 15138 & 4,0 \\
\hline Инвалиды, не имеющие степени ограничения & 125 & 0,1 & 496 & 0,1 \\
\hline $\begin{array}{l}\text { Граждане, подвергшиеся воздействию радиации вследствие аварии на ЧАЭС, и } \\
\text { лица, к ним приравненные }\end{array}$ & 1411 & 1,3 & 4162 & 1,1 \\
\hline Итого & 112524 & & 378581 & \\
\hline
\end{tabular}




\begin{tabular}{|c|c|c|c|c|c|c|c|c|c|c|c|c|c|c|c|c|c|}
\hline $\bar{i}$ & $\begin{array}{l}\hat{1} \\
80\end{array}$ & $\begin{array}{l}\dot{ن} \\
\dot{I}\end{array}$ & $\begin{array}{l}\dot{j} \\
\mathbf{I}\end{array}$ & $\underset{\dot{I}}{\dot{ن}}$ & $\begin{array}{l}\dot{ن} \\
\dot{I}\end{array}$ & $\begin{array}{l}\dot{U} \\
\dot{I}\end{array}$ & $\begin{array}{l}\dot{\dot{I}} \\
\dot{I}\end{array}$ & $\begin{array}{l}\dot{\dot{S}} \\
\dot{I}\end{array}$ & $\begin{array}{l}\dot{\dot{I}} \\
\dot{I}\end{array}$ & $\begin{array}{l}\dot{U} \\
\dot{I}\end{array}$ & $\begin{array}{l}\dot{U} \\
\dot{I}\end{array}$ & $\begin{array}{l}\dot{U} \\
\dot{I}\end{array}$ & $\begin{array}{l}\dot{I} \\
\dot{I}\end{array}$ & $\underset{\dot{I}}{\dot{ن}}$ & $\begin{array}{l}\dot{U} \\
\dot{I}\end{array}$ & $\begin{array}{l}\dot{U} \\
\dot{I}\end{array}$ & \begin{tabular}{|l}
$\dot{U}$ \\
$\dot{I}$
\end{tabular} \\
\hline 울 & $\stackrel{\circ}{N}$ & $\stackrel{\nabla}{\leftarrow}$ & $\stackrel{50}{5}$ & $\stackrel{m}{\sim}$ & $\begin{array}{l}m \\
\sim \\
\sim\end{array}$ & $\mid \begin{array}{l}N \\
\text { L }\end{array}$ & $\stackrel{\mathscr{N}}{\sim}$ & $\bar{i}$ & $\begin{array}{l}n \\
0 \\
0\end{array}$ & $\hat{\tilde{m}}$ & $\stackrel{\infty}{\leftarrow}$ & $=$ & $0^{\circ}$ & $\begin{array}{l}0 \\
\dot{\sigma}^{-}\end{array}$ & $\stackrel{+}{\circ}$ & $\begin{array}{l}\dot{U} \\
\dot{I}\end{array}$ & $\stackrel{\circ}{\circ}$ \\
\hline ஓे & $\frac{0}{\infty}$ & $\stackrel{\nabla}{\sim}$ & 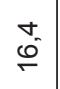 & $\stackrel{\circ}{\circ}$ & $\stackrel{\mathcal{N}}{\underset{\leftarrow}{\tau}}$ & $\stackrel{0}{N}$ & $\stackrel{\sim}{\sim}$ & $\stackrel{0}{\sim}$ & $\begin{array}{c}N \\
0 \\
0\end{array}$ & $\begin{array}{l}\text { Na } \\
\tilde{m}\end{array}$ & $\stackrel{\leftrightarrow}{\leftarrow}$ & 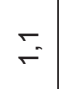 & $\overbrace{0}^{m}$ & $\mid \begin{array}{l}0 \\
15\end{array}$ & $\stackrel{L}{0}$ & $\begin{array}{c}n \\
0 \\
0\end{array}$ & 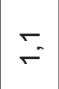 \\
\hline 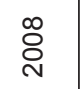 & 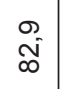 & $\stackrel{n}{=}$ & $\begin{array}{l}\stackrel{0}{+} \\
\underset{+}{+}\end{array}$ & $\stackrel{m}{\sim}$ & $\begin{array}{l}\infty \\
f^{-}\end{array}$ & $\stackrel{N}{\sim}$ & $\begin{array}{l}0 \\
\stackrel{m}{n}\end{array}$ & $\begin{array}{c}m \\
m\end{array}$ & $\begin{array}{c}m \\
0 \\
0\end{array}$ & $\stackrel{+}{\stackrel{m}{m}}$ & $\stackrel{\infty}{=}$ & $\stackrel{N}{=}$ & $\stackrel{N}{0}$ & छे & 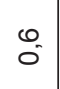 & $\overline{0}$ & $\stackrel{N}{\sim}$ \\
\hline ڤ్రి & $\begin{array}{l}\infty \\
\tilde{\sigma} \\
\tilde{\sigma}\end{array}$ & $\stackrel{0}{r}$ & $\begin{array}{c}0 \\
\stackrel{0}{\Gamma}\end{array}$ & $\stackrel{0}{r}$ & $\begin{array}{l}\sigma_{0} \\
0\end{array}$ & $\begin{array}{c}N \\
\infty \\
\infty\end{array}$ & $\stackrel{\leftrightarrow}{i}$ & 요 & $\begin{array}{l}m \\
0 \\
0\end{array}$ & $\stackrel{m}{\stackrel{一}{\sigma}}$ & $\stackrel{\infty}{\sim}$ & $\stackrel{\sim}{\sim}$ & $\bar{\sigma}$ & $\bar{N}$ & $\stackrel{\infty}{0}_{\circ}^{-}$ & $\overline{0}$ & $\underset{\sim}{\sigma}$ \\
\hline \&̊․ & $\begin{array}{c}\tilde{N} \\
\tilde{N} \\
\stackrel{w}{\sim}\end{array}$ & $\tilde{N}$ & $\stackrel{-}{\stackrel{-}{\infty}}$ & $\stackrel{\leftrightarrow}{m}$ & $\stackrel{g}{N}$ & $\hat{\stackrel{m}{m}}$ & in & $\begin{array}{c}N \\
\infty \\
\infty\end{array}$ & $\begin{array}{l}0 \\
0 \\
0\end{array}$ & $\begin{array}{l}0 \\
\mathbb{8}\end{array}$ & $\stackrel{\mathscr{L}}{m}$ & $\stackrel{\infty}{=}$ & $\stackrel{\leftrightarrow}{\sim}$ & $\stackrel{t}{\infty}$ & $\begin{array}{l}\infty \\
0 \\
0\end{array}$ & $\overline{0}$ & $\stackrel{m}{i}$ \\
\hline ஜ̊ํㅇ & $\begin{array}{l}0 \\
\stackrel{-}{F} \\
\end{array}$ & $\bar{i}$ & $\begin{array}{l}\stackrel{N}{\sigma} \\
\stackrel{5}{\sigma}\end{array}$ & is & $\begin{array}{l}\infty \\
\infty \\
\infty\end{array}$ & $\begin{array}{l}0 \\
0 \\
10\end{array}$ & $\begin{array}{l}0 \\
\stackrel{\sigma}{*}\end{array}$ & $\begin{array}{l}\infty \\
\stackrel{\infty}{0} \\
0\end{array}$ & \begin{tabular}{|l|}
0 \\
0 \\
0
\end{tabular} & $\begin{array}{l}N \\
\bar{\sigma}\end{array}$ & $\begin{array}{l}0 \\
0\end{array}$ & $\stackrel{\circ}{\mathrm{N}}$ & $\bar{\circ}_{\circ}^{\circ}$ & $\mid \begin{array}{l}\checkmark \\
\infty\end{array}$ & $\hat{0}$ & $\begin{array}{l} \pm \\
O \\
0\end{array}$ & $\stackrel{n}{m}$ \\
\hline ఫે & $\begin{array}{l}m \\
\stackrel{0}{\sigma} \\
\stackrel{\sigma}{*}\end{array}$ & $\stackrel{\circ}{i}$ & $\hat{\hat{\infty}^{-}}$ & $\bar{s}$ & \begin{tabular}{|l|}
0 \\
$\infty$ \\
$\infty$
\end{tabular} \mid & 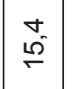 & $\begin{array}{l}\llcorner 0 \\
\stackrel{f}{*}\end{array}$ & $\hat{0}$ & 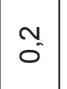 & $\begin{array}{l}\infty \\
\tilde{\sim} \\
\stackrel{-}{-1}\end{array}$ & $\stackrel{m}{m}$ & $\stackrel{\leftrightarrow}{\circ}$ & 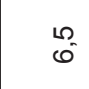 & $\bar{\sigma}$ & $\hat{\circ}$ & $\begin{array}{l}\dot{U} \\
\dot{I}\end{array}$ & 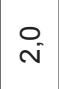 \\
\hline ڤ్రి & \begin{tabular}{|l|}
0 \\
$\varnothing$ \\
$\infty$
\end{tabular} & $\stackrel{m}{N}$ & $\begin{array}{l}\stackrel{g}{f} \\
\underset{\leftarrow}{\leftarrow}\end{array}$ & $\stackrel{m}{N}$ & \begin{tabular}{l|}
$\infty$ \\
\multirow{\leftarrow}{*}{}
\end{tabular} & $\stackrel{L}{N}$ & $\approx$ & $\stackrel{m}{m}$ & $\overline{0}$ & $\stackrel{i}{\bar{m}}$ & $\stackrel{\stackrel{\sim}{N}}{\sim}$ & $\stackrel{\cong}{=}$ & $\overline{5}$ & $\stackrel{L}{N}$ & $\stackrel{\circ}{\circ}$ & $\begin{array}{l}\dot{ن} \\
\dot{I}\end{array}$ & $\stackrel{0}{-}$ \\
\hline ర్ & $\begin{array}{l}\circ \\
\ddot{\circ}\end{array}$ & $\bar{i}$ & $\begin{array}{l}m \\
\stackrel{5}{\leftarrow} \\
\stackrel{5}{n}\end{array}$ & $\stackrel{\bullet}{\sim}$ & $\hat{i}$ & $\stackrel{m}{N}$ & $\begin{array}{l}0 \\
\stackrel{m}{m}\end{array}$ & $\stackrel{+}{m}$ & $\stackrel{m}{0}^{\prime}$ & \begin{tabular}{l}
$\stackrel{N}{*}$ \\
\multirow{J}{*}{}
\end{tabular} & $\bar{m}$ & $\begin{array}{l}\infty \\
0^{-}\end{array}$ & $\stackrel{\infty}{\circ}^{\circ}$ & $\stackrel{\Delta}{\sim}$ & $\hat{0}$ & $\begin{array}{l}\dot{I} \\
\dot{I}\end{array}$ & $\stackrel{N}{\sim}$ \\
\hline চ̊̀ & $\begin{array}{l}\dot{0} \\
\stackrel{0}{\circ}\end{array}$ & $\stackrel{\circ}{m}$ & $\check{\nabla}$ & $\begin{array}{l}\infty \\
\stackrel{N}{N}\end{array}$ & $\mid \begin{array}{c}\mathfrak{N} \\
0^{\prime}\end{array}$ & $\bar{\infty}^{-}$ & $\begin{array}{l}\dot{U} \\
\dot{I}\end{array}$ & $\begin{array}{l}\dot{U} \\
\dot{I}\end{array}$ & $\begin{array}{l}\dot{U} \\
\dot{I}\end{array}$ & \begin{tabular}{|l|}
$\infty$ \\
$\mathcal{J}^{-}$ \\
\end{tabular} & $\stackrel{N}{\tilde{m}}$ & $\stackrel{N}{N}$ & $\underset{m}{m}$ & Oे & $\stackrel{\circ}{\circ}$ & $\begin{array}{l}10 \\
0 \\
0\end{array}$ & $\stackrel{I}{=}$ \\
\hline ه্․ & $\begin{array}{l}m \\
\dot{8} \\
\dot{8}\end{array}$ & $\bar{m}$ & $\begin{array}{l}0 \\
0 \\
0\end{array}$ & $\bar{m}$ & $\begin{array}{l}N \\
m \\
m\end{array}$ & $\begin{array}{l}m \\
\sigma\end{array}$ & $\begin{array}{l}\dot{U} \\
\dot{I}\end{array}$ & $\begin{array}{l}\dot{S} \\
\dot{I}\end{array}$ & 宔 & $\overline{8}$ & $\begin{array}{l}N \\
\tilde{m}\end{array}$ & $\stackrel{\nabla}{\sim}$ & $\begin{array}{c}N \\
\text { in }\end{array}$ & $\check{N}$ & $\hat{0}$ & $\begin{array}{l}n \\
0 \\
0\end{array}$ & $\begin{array}{l}0 \\
m^{-}\end{array}$ \\
\hline 泾 & $\begin{array}{l}\tilde{N} \\
\tilde{S}\end{array}$ & $\stackrel{\stackrel{N}{N}}{*}$ & $\stackrel{0}{\stackrel{0}{*}}$ & $\stackrel{0}{i}$ & $\begin{array}{l}0 \\
0\end{array}$ & $\stackrel{m}{\sim}$ & $\begin{array}{l}\dot{U} \\
\dot{I}\end{array}$ & $\begin{array}{l}\dot{S} \\
\dot{I}\end{array}$ & $\mid \begin{array}{l}\dot{I} \\
\end{array}$ & $\bar{g}$ & $\bar{m}$ & $\stackrel{\forall}{\leftarrow}$ & in & $\hat{N}$ & $\hat{0}$ & $\begin{array}{l}\dot{\dot{I}} \\
\dot{I}\end{array}$ & $\begin{array}{l}0 \\
m^{-}\end{array}$ \\
\hline$\stackrel{\infty}{\stackrel{\circ}{్}}$ & $\begin{array}{l}\infty \\
8 \\
8\end{array}$ & $\stackrel{\sim}{\sim}$ & $\begin{array}{l}0 \\
\circ \\
\div\end{array}$ & $\overline{\mathrm{i}}$ & $\begin{array}{l}0 \\
0\end{array}$ & $\stackrel{\infty}{N}$ & $\begin{array}{l}\dot{U} \\
\dot{I}\end{array}$ & $\begin{array}{l}\dot{S} \\
\dot{I}\end{array}$ & ن্ & \begin{tabular}{|c|}
0 \\
$\mathscr{J}$ \\
$\forall$
\end{tabular} & $\begin{array}{l}\infty \\
\sim \\
\sim\end{array}$ & 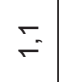 & $\stackrel{n}{\circ}$ & $\hat{\kappa}$ & $\hat{0}$ & $\begin{array}{l}\dot{U} \\
\dot{I}\end{array}$ & $\begin{array}{l}\infty \\
\sim \\
\sim\end{array}$ \\
\hline S્ & $\begin{array}{l}0 \\
\stackrel{-}{0} \\
\stackrel{0}{2}\end{array}$ & $\stackrel{10}{\sim}$ & $\underset{\sim}{\check{J}}$ & $\stackrel{\nabla}{\sim}$ & $\begin{array}{l}\sigma_{0}^{-} \\
\sigma^{\prime}\end{array}$ & $\begin{array}{l}0 \\
\infty\end{array}$ & $\begin{array}{l}\dot{U} \\
\dot{I}\end{array}$ & $\overline{\sigma o}^{\circ}$ & $\begin{array}{l}\dot{U} \\
\dot{I}\end{array}$ & \begin{tabular}{l|}
0 \\
$\dot{f}$
\end{tabular} & 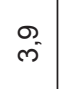 & $\stackrel{\circ}{\sim}$ & $\stackrel{0}{\stackrel{+}{*}}$ & 0 & $\stackrel{\circ}{r}$ & $\sigma_{0}^{-}$ & $\begin{array}{l}\infty \\
\infty^{-}\end{array}$ \\
\hline$\stackrel{\mathscr{ஜ}}{\circ}$ & $\begin{array}{l}m \\
\stackrel{0}{8} \\
\stackrel{2}{*}\end{array}$ & $\stackrel{\leftrightarrow}{i}$ & \begin{tabular}{l|} 
\\
$\stackrel{N}{\sim}$ \\
\end{tabular} & $\stackrel{s}{\sim}$ & $\mid \begin{array}{l}N \\
0 \\
0\end{array}$ & $\underset{\infty}{N}$ & $\begin{array}{l}\dot{\dot{x}} \\
\dot{I}\end{array}$ & $\overline{60}^{\circ}$ & $\begin{array}{l}\dot{0} \\
\dot{I}\end{array}$ & 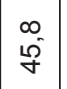 & $\begin{array}{l}\infty \\
\stackrel{\infty}{m}\end{array}$ & $\stackrel{\circ}{=}$ & $\stackrel{\infty}{m^{-}}$ & $\begin{array}{l}\infty \\
\sim\end{array}$ & $=$ & $\bar{\sigma}$ & 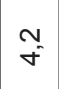 \\
\hline ঙ̊ & $\begin{array}{c}\overline{0} \\
\stackrel{5}{\digamma}\end{array}$ & $\stackrel{L}{N}$ & $\begin{array}{l}\stackrel{\leftrightarrow}{\mathrm{I}} \\
\stackrel{\mathrm{N}}{ }\end{array}$ & $\stackrel{\infty}{N}$ & $\hat{0}$ & ó & $\begin{array}{l}\dot{\dot{x}} \\
\dot{I}\end{array}$ & Õ & $\left|\begin{array}{l}\dot{0} \\
\dot{I}\end{array}\right|$ & \begin{tabular}{|c|}
0 \\
$\stackrel{1}{\circ}$ \\
$i$
\end{tabular} & 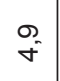 & $\stackrel{0}{\leftarrow}$ & $\stackrel{\sim}{m}$ & \begin{tabular}{|l|}
0 \\
0
\end{tabular} & $\begin{array}{l}\infty \\
0 \\
0\end{array}$ & $\tilde{N}$ & $\begin{array}{l}\infty \\
\leftarrow \\
\forall\end{array}$ \\
\hline 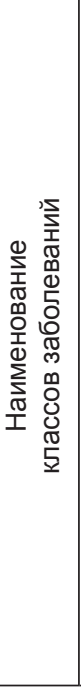 & 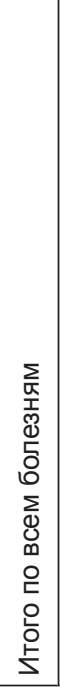 & 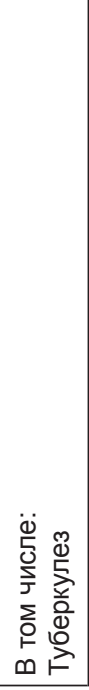 & 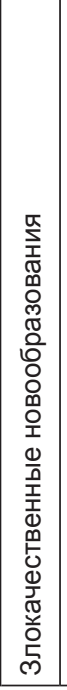 & 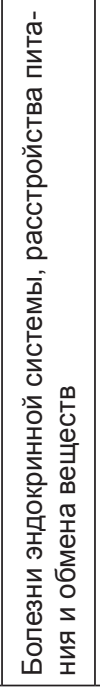 & 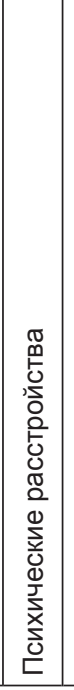 & 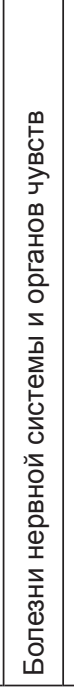 & 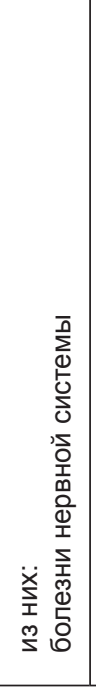 & 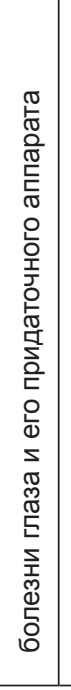 & 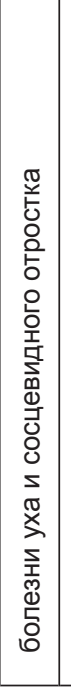 & 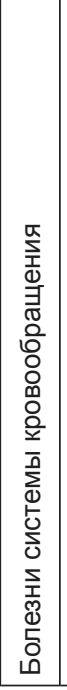 & 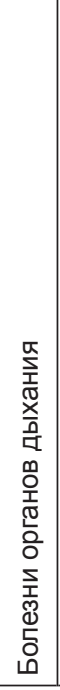 & 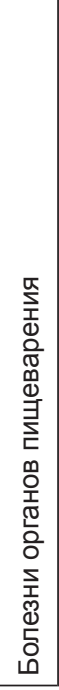 & 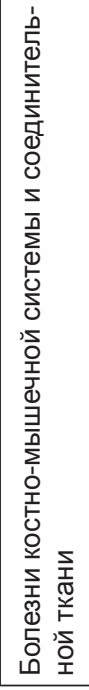 & 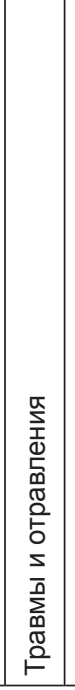 & 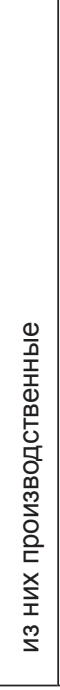 & 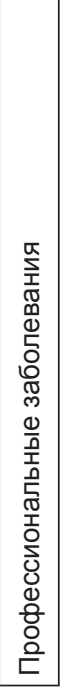 & 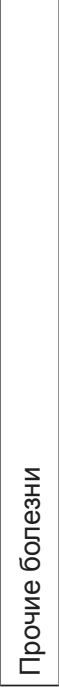 \\
\hline
\end{tabular}




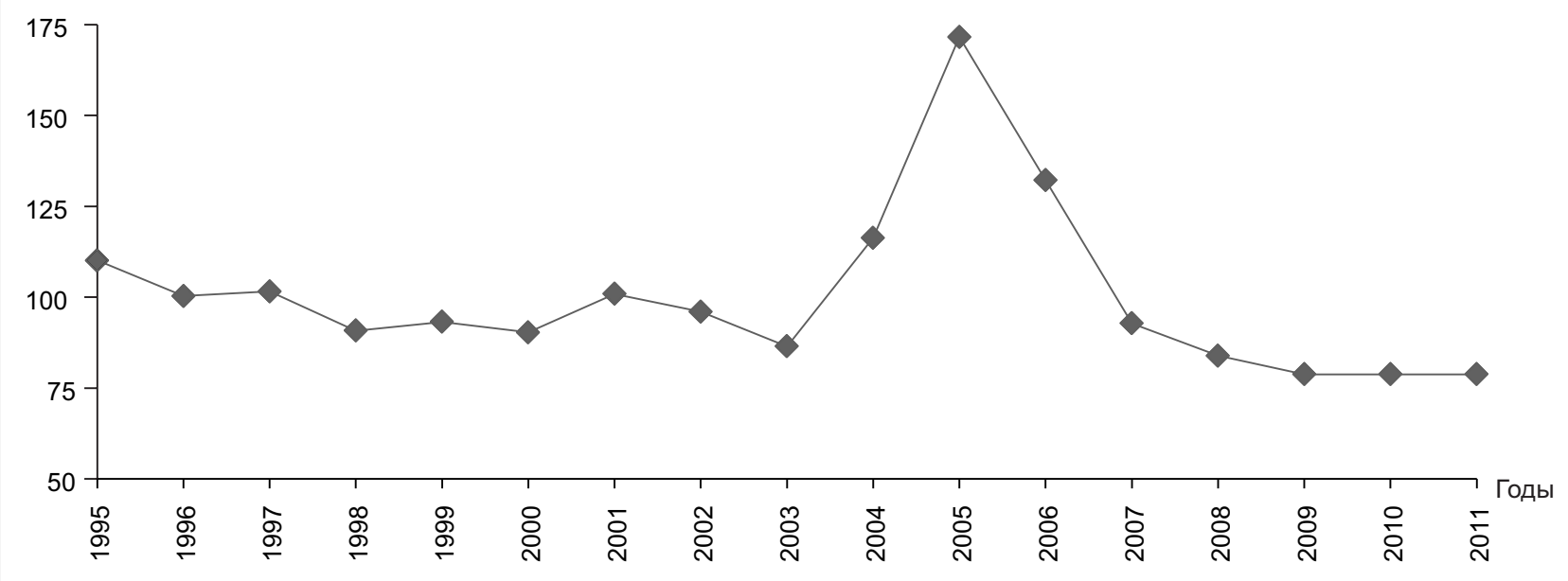

Рис. 1. Первичный выход на инвалидность среди взрослых (18 лет и старше) по г. Казани за 1995-2011 гг., на 10 тыс. взрослого населения

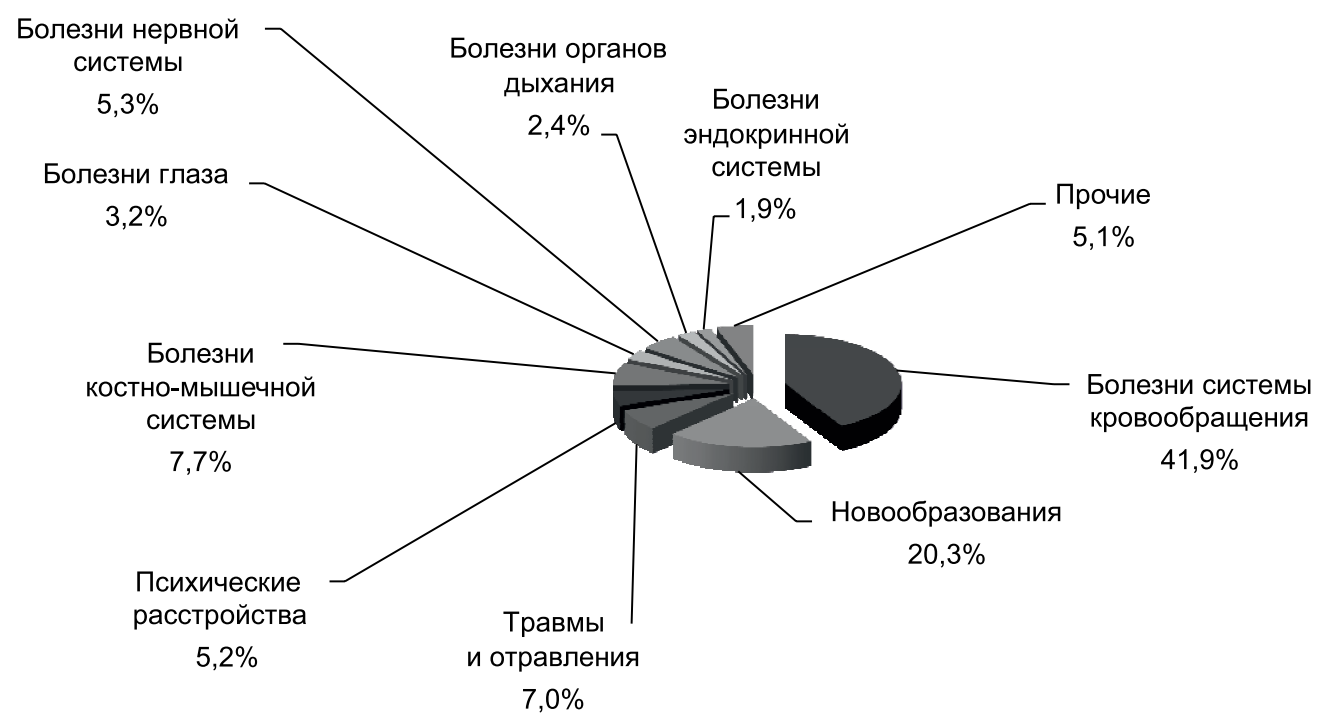

Рис. 2. Структура первичного выхода на инвалидность взрослого населения г. Казани за 2011 г., \%

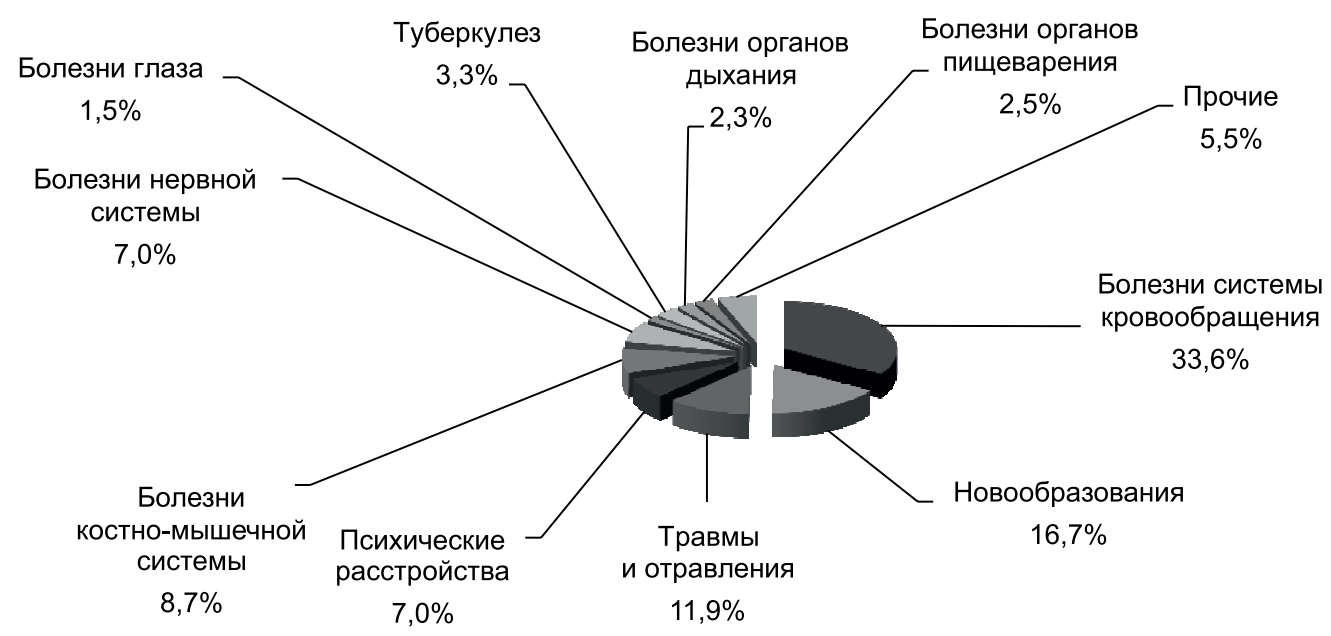

Рис. 3. Структура первичного выхода на инвалидность лиц трудоспособного возраста г. Казани за 2011 г., \% 


\section{Выводы:}

1. Распространенность инвалидности в г. Казани в 1995 г. составила 115,4, в 2011 г. этот показатель снизился до 112,5 на 10 тыс. населения.

2. Распространенность первичного выхода на инвалидность снизился с 110,1 случая на 10 тыс. населения в 1995 г. до 65,7 случая в 2011 г. Прогностический коэффрициент снижения этого показателя до 2016 г. составит 37,3\%.

3. Уменьшение коэффициента инвалидности за 1995-2011 гг. произошло за счет снижения болезней туберкулеза на 44\%, психических расстройств — на $38,8 \%$, эндокринной системы - на $60,7 \%$, кровообращения - на $38,4 \%$ и органов пищеварения на $31,3 \%$.

4. Рост коэфффициента инвалидности за наблюдаемый период произошел за счет злокачественных новообразований на 27,0\%, болезней костномышечной системы - на $51,5 \%$.

5. Полученные данные рекомендуется использовать для прогнозирования инвалидности, планирования лечебно-профилактических и реабилитационных мероприятий.

\section{ЛИТЕРАТУРА}

1. Системный анализ развития медико-демографических процессов в мегаполисе в период социальноэкономических реформ: монография / А.Н. Галиуллин, Н.Н. Шамсияров, А.В. Глушаков [и др]. - Казань: Медицина, 2013. - 122 с.

2. Гришина, Л.П. Основные показатели первичной инвалидности в Российской Федерации / Л.П. Гришина // Статистический сборник. - М.: Федеральное бюро медико-социальной экспертизы, 2013. - 222 с.

3. Ихсанов, Х.В. Медико-социальные аспекты инвалидности трудоспособного населения в Республике Татарстан / Х.В. Ихсанов // Медико-социальная экспертиза и реабилитация. - 2007. - № 1. - С.5-8.

4. Кардаков, Н.Л. Закономерности формирования контингента инвалидов молодого возраста по обращаемости в бюро медико-социальной экспертизы Российской Федерации / Н.Л. Кардаков // Медико-социальная экспертиза и реабилитация. - 2006. - № 3. - С.28-32.

5. Науменко, Л.Л. Анализ фракторов, влияющих на показатели инвалидности детского населения / Л.Л. Науменко. - 2012. - URL: http://iroddi28.ucoz. ru/publ/sotrudnikam/interesnye_stati/analiz_faktorov_ vlijajushhikh_na_pokazateli_invalidnosti_detskogo naselenija/10-1-0-12 (дата обращения: 15.12.2013).

6. Пьянкова, И.В. Медико-социальная экспертиза при болезнях органов дыхания / И.В. Пьянкова // Медикосоциальная экспертиза и реабилитация. - 2007. № 3. - C.23-24.
7. Шлыкова, М.В. Возрастные особенности первичной инвалидности взрослого населения вследствие болезней системы кровообращения в Российской Федерации / М.В. Шлыкова // Медико-социальная экспертиза и реабилитация. - 2008. - № 8. - С.23-25.

\section{REFERENCES}

1. Sistemnyi analiz razvitiya mediko-demograficheskih processov $v$ megapolise $v$ period social'no-ekonomicheskih reform: monografiya [System analysis of development of medico-demographic processes in the megalopolis during social and economic reforms: monograph] / A.N. Galiullin, N.N. Shamsiyarov, A.V. Glushakov [i dr]. - Kazan': Medicina, 2013. - $122 \mathrm{~s}$.

2. Grishina, L.P. Osnovnye pokazateli pervichnoi invalidnosti v Rossiiskoi Federacii / L.P. Grishina // Statisticheskii sbornik. - M.: Federal'noe byuro mediko-social'noi ekspertizy, 2013. - $222 \mathrm{~s}$.

3. Ihsanov, H.V. Mediko-social'nye aspekty invalidnosti trudosposobnogo naseleniya $v$ Respublike Tatarstan [Medical and social aspects of disability of the working population in the Republic of Tatarstan] / H.V. Ihsanov // Mediko-social'naya ekspertiza i reabilitaciya. — 2007. № $1 .-\mathrm{S} .5-8$.

4. Kardakov, N.L. Zakonomernosti formirovaniya kontingenta invalidov molodogo vozrasta po obraschaemosti v byuro mediko-social'noi ekspertizy Rossiiskoi Federacii [Laws of formation of a contingent of young disabled uptake in the Bureau of Medical and Social Expertise of the Russian Federation] / N.L. Kardakov // Mediko-social'naya ekspertiza i reabilitaciya [Medical-social examination and rehabilitation]. - 2006. - № 3. - S.28-32.

5. Naumenko, L.L. Analiz faktorov, vliyayuschih na pokazateli invalidnosti detskogo naseleniya [Analysis of factors affecting the performance of disability of the child population] / L.L. Naumenko. - 2012. - URL: http:// iroddi28.ucoz.ru/publ/sotrudnikam/interesnye_stati/ analiz_faktorov_vlijajushhikh_na_pokazateli_invalidnosti detskogo_nasēenija/10-1-0-12 (data obrascheniya: 15.12.2013).

6. P'yankova, I.V. Mediko-social'naya ekspertiza pri boleznyah organov dyhaniya [Medical and social expertise in diseases of the respiratory system] / I.V. P'yankova // Mediko-social'naya ekspertiza i reabilitaciya [Medicalsocial examination and rehabilitation]. - 2007. - № 3. S.23-24.

7. Shlykova, M.V. Vozrastnye osobennosti pervichnoi invalidnosti vzroslogo naseleniya vsledstvie boleznei sistemy krovoobrascheniya v Rossiiskoi Federacii [Age characteristics of primary disability of the adult population as a consequence of diseases of the circulatory system in the Russian Federation] / M.V. Shlykova // Medikosocial'naya ekspertiza i reabilitaciya [Medical-social examination and rehabilitation]. - 2008. - № 8. S.23-25. 


\title{
НОВЫЙ ИНСТРУМЕНТ И СПОСОБ, ОБЛЕГЧАЮЩИЙ ЗАВЯЗЫВАНИЕ ХИРУРГИЧЕСКИХ УЗЛОВ ПРИ ЛАПАРОСКОПИЧЕСКИХ ГИНЕКОЛОГИЧЕСКИХ ОПЕРАЦИЯХ
}

\author{
ОЛЕГ ВЛАДИМИРОВИЧ ГАЛИМОВ, докт. меД. наук, проф., зав. кафедрой Хирургических болезней \\ и новых технологий с курсом ИПО ГБОУ ВПО «Башкирский государственный медицинский университет» \\ Минздрава России, Уфа, Россия, тел. +7(347) 223-11-92, e-mail: kbgmu@rambler.ru \\ ЭЛИНА ЮРЬЕВНА ДМИТРИЕВА, врач-акушер-гинеколог, аспирант кафедры хирургических болезней \\ и новых технологий с курсом ИПО ГБОУ ВПО «Башкирский государственный медицинский университет» \\ Минздрава России, Уфа, Россия \\ ВЛАДИСЛАВ ОЛЕГОВИЧ ХАНОВ, докт. меД. наук, проф. кафедры Хирургических болезней и новых технологий \\ с курсом ИПО ГБОУ ВПО «Башкирский государственный медицинский университет» Минздрава России, Уфа, \\ Россия, тел. +7-917-755-62-82, e-mail: khanovv@mail.ru \\ ОКСАНА АЛЕКСАНДРОВНА ФИЛИППОВА, врач-акушер-гинеколог, аспирант кафедры хирургических болезней \\ и новых технологий с курсом ИПО ГБОУ ВПО «Башкирский государственный медицинский университет» \\ Минздрава России, Уфа, Россия
}

\begin{abstract}
Реферат. Цель исследования - внедрение в гинекологическую практику при выполнении эндоскопических оперативных вмешательств устройства для завязывания экстракорпоральных узлов. Материал и методы. Авторский способ был применен в клинике БГМУ при выполнении лапароскопических гинекологических вмешательств у 79 пациенток. Результаты и их обсуждение. В ходе наблюдения пациенток, которым была применена методика завязывания экстракорпоральных узлов, каких-либо осложнений, связанных с предложенным способом, не наблюдалось. При этом всегда достигалось адекватное завязывание и затягивание лигатурных узлов в труднодоступных местах и обеспечение удобства в работе при проведении лапароскопических операций. Нами также отмечено, что использование предложенного способа позволило повысить удобство фрормирования узлов, сократить время и травматичность операции, улучшить непосредственные результаты лечения. Заключение. Использование предложенного способа позволяет добиться уменьшения трудоемкости и повышения удобства формирования узлов, что сокращает время и травматичность операции, улучшает непосредственные результаты лечения. Ключевые слова: гинекология, лапароскопия, устройство для завязывания узлов.
\end{abstract}

\section{NEW TOOL AND METHOD OF TYING SURGICAL UNITS IN LAPAROSCOPIC GYNECOLOGICAL SURGERY}

OLEG V. GALIMOV, Doctor of Medical Science, Professor, Head of the Department of surgical diseases and new technologies of SBEI HPE «Bashkir State Medical University» of Russian Ministry of Health, Ufa, Russia, tel. +7(347) 223-11-92, e-mail: kbgmu@rambler.ru

ELINA YU. DMITRIEVA, obstetrician-gynecologist, a graduate student of the Department of surgical diseases and new technologies of SBEI HPE «Bashkir State Medical University» of Russian Ministry of Health, Ufa, Russia VLADISLAV O. KHANOV, Doctor of Medical Science, Professor of the Department of surgical diseases and new technologies of SBEI HPE «Bashkir State Medical University» of Russian Ministry of Health, Ufa, Russia, tel. +7-917-755-62-82, e-mail: khanovv@mail.ru

OKSANA A. FILIPPOVA, obstetrician-gynecologist, a graduate student of the Department of surgical diseases and new technologies of SBEI HPE «Bashkir State Medical University» of Russian Ministry of Health, Ufa, Russia

\begin{abstract}
Aim. Implementation the devices for extracorporal knots setting in endoscopic operations in gynecologic practice. Material and methods. The Author's method was applied in clinic of BGMU in laparoscopic gynecologic interventions at 79 patients. Results and its discussion. During the observation of trial patients with applied technique of setting of extracorporal knots, we did not observe any complications bound to the offered way. Thus, we always observed adequate setting and a tightening of the ligature knots in hard-to-reach spots, and reached convenience in work when carrying out laparoscopic operations. Conclusion. We also noticed that use of the offered way allowed to increase convenience of formation of knots, to reduce time and injury of operation, to improve short-term results of treatment.
\end{abstract}

Key words: gynecology, laparoscopic surgery, the device for tying knots.

$\mathrm{B}$ настоящее время неотъемлемой составной частью минимально инвазивной хирургии является ручной эндохирургический шов. Развитие и распространение лапароскопических оперативных вмешательств достигло той степени, когда дальней- шее достижение хорошего результата невозможно без использования ручного сшивания тканей и формирования узлов. Уже разработаны и изучены многие аспекты применения и техники ручного шва в эндохирургии, а именно: выбор шовного материала, 
выбор вида шва и формирования узла в конкретных клинических условиях, техника прошивания тканей и формирование эндохирургических узлов, ограничение эндохирургического шва [1, 2]. Тем не менее вопрос о наложении эндохирургических узлов остается открытым, так как существует возможность качественного улучшения проведения данной процедуры при лапароскопических вмешательствах за счет разработки принципиально новых специальных устройств.

Известно использование различных сложных инструментов и конструкций для завязывания и затягивания лигатурных узлов, содержащих цилиндрический корпус, стержень с коническим концом, трубку, фриксатор, механизм управления зажимом, рукоятку, рычаг и захватное устройство (Авторское свидетельство на изобретение RU 94007665, опубликовано в 1996 г.). Применение данной полезной модели имеет ряд недостатков, основными из которых являются: трудности в эксплуатации данного устройства из-за его сложного механизма; затрачивание значительного количества времени на проведение оперативного лечения.

Для упрощения и ускорения процедуры формирования узлов при проведении лапароскопических операций нами разработано оригинальное устройство (Российский патент на полезную модель № 118183 от 20.07.2012, Бюл. 20).

Технический результат полезной модели уменьшение трудоемкости и повышение удобства формирования узлов, сокращения времени проведения операции. Указанный технический результат достигается тем, что устройство для фрормирования узлов при выполнении лапароскопических операций, согласно полезной модели, содержит рукоятку с рифлением, на рабочем конце которой выполнен перешеек с фиксатором подковообразной формы.
Предлагаемая полезная модель представлена на рис. 1 , на котором изображено предлагаемое устройство, общий вид.

Предлагаемое устройство состоит из рукоятки с рифрлением для удобного расположения в руке хирурга, перешейка и фиксатора подковообразной формы, благодаря которому осуществляется затягивание сформированных узлов при выполнении лапароскопических вмешательств. Полезная модель используется следующим образом: при лапароскопическом вмешательстве хирург фрормирует экстракорпоральный эндоузел (рис. 2), берет устройство за рукоятку, проводит через троакар в брюшную полость с захватом сформированного узла фиксатором подковообразной формы, причем перешеек обеспечивает удобный угол захвата и большую площадь соприкосновения с узлом, после чего движением руки инструмент продвигают глубже через троакар, в результате чего производится затягивание сорормированного узла (рис. 3).

Использование полезной модели значительно уменьшает трудоемкость и повышает удобство формирования узлов, сокращает время проведения операции. Владение инструментом и техникой наложения эндоскопического шва придает хирургу необходимую уверенность в себе и позволяет ему осуществлять минимально инвазивную методику.

Способ применен в клинике при выполнении лапароскопических гинекологических вмешательств у 79 пациенток. Осложнений, связанных с применением методики, отмечено не было. При этом всегда достигалось адекватное завязывание и затягивание лигатурных узлов в труднодоступных местах и обеспечение удобства в работе при проведении лапароскопических операций. При сравнении длительности вмешательства проводимых при
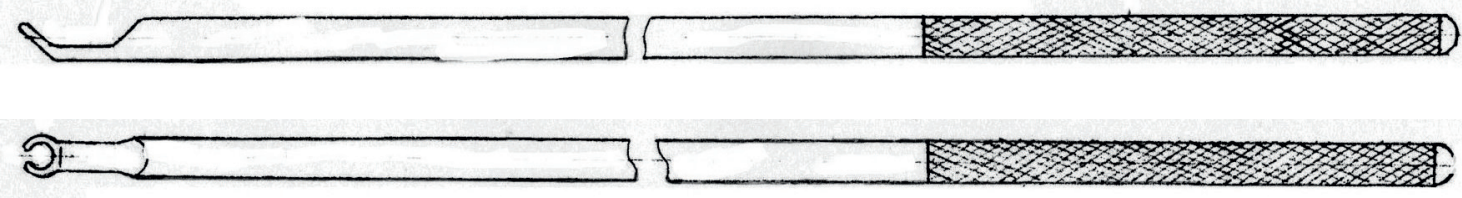

Рис. 1. Устройство для формирования узлов при выполнении лапароскопических операций

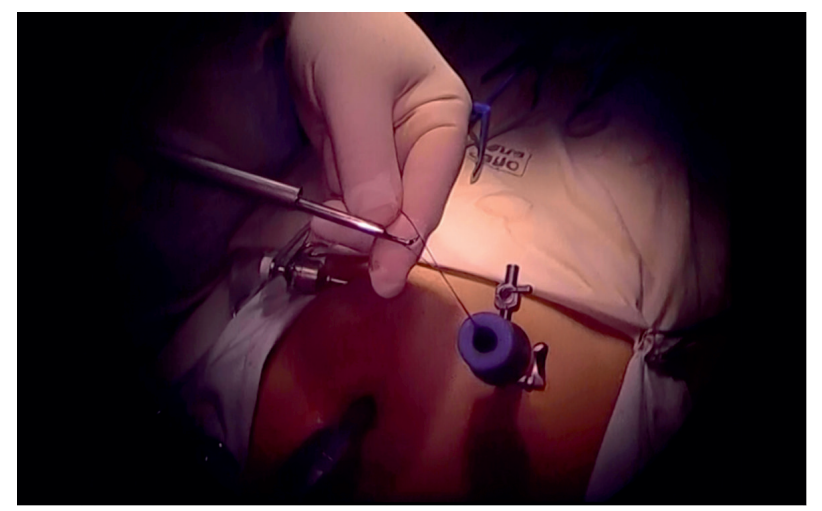

Рис. 2. Формирование узлов при выполнении лапароскопических операций

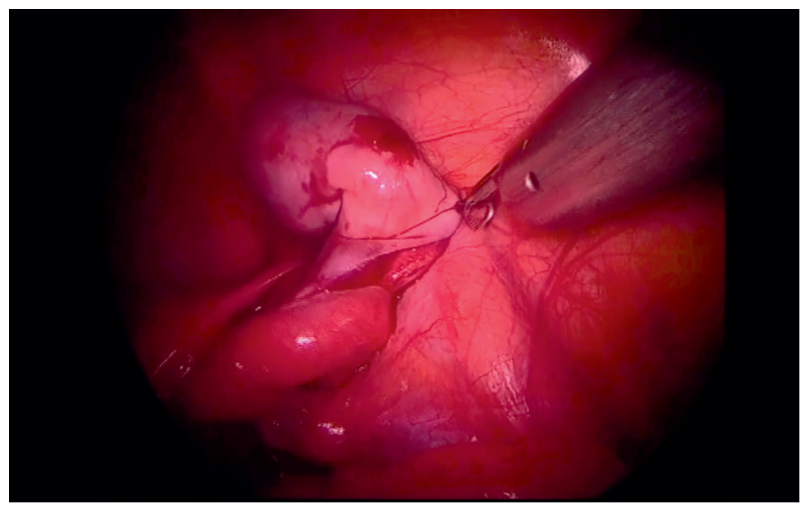

Рис. 3. Устройство для формирования узлов. Законченный вид манипуляции 
однотипных лапароскопических вмешательствах (27 пациенток группы сравнения) установлено, что в целом средняя продолжительность операций в группе сравнения была на $(18 \pm 5,2)$ мин больше, чем в основной группе. Таким образом, использование предложенного способа позволяет добиться уменьшения трудоемкости и повышения удобства фрормирования узлов, что сокращает время и травматичность операции, улучшает непосредственные результаты лечения.

\section{ЛИТЕРАТУРА}

1. Федоров, И.В. Осложнения эндоскопической хирургии, гинекологии и урологии / И.В. Федоров, Е.И. Сигал, М.В. Бурмистров. - М.: Триада-Х, 2012. - 283 с.
2. Panniculectomy and abdominoplasty in patients undergoing gynecologic surgery: a single center case series of 15 combined procedures / S.A. Wallace, A.F. Mericli, P.T. Taylor, D.B. Drake // Ann. Plast. Surg. - 2013. № 71(1). - P.88-92.

\section{REFERENCE}

1. Fedorov, I.V. Oslozhneniya endoskopicheskoi hirurgii, ginekologii i urologii [Complications of Endoscopic Surgery, Gynecology and Urology] / I.V. Fedorov, E.I. Sigal, M.V. Burmistrov. - M.: Triada-H, 2012. - $283 \mathrm{~s}$.

2. Panniculectomy and abdominoplasty in patients undergoing gynecologic surgery: a single center case series of 15 combined procedures / S.A. Wallace, A.F. Mericli, P.T. Taylor, D.B. Drake // Ann. Plast. Surg. - 2013. № 71(1). - P.88-92.

() П.В. Токарев, А.В. Шулаев, Л.В. Плаксина, 2015

удК [616.315+616.317]-007.254-053.2-08(470.41)

\section{КОМПЛЕКСНЫЙ ПОДХОД В ЛЕЧЕНИИ ДЕТЕЙ С ВРОЖДЕННЫМИ РАСЩЕЛИНАМИ ВЕРХНЕЙ ГУБЫ И НЁБА В РЕСПУБЛИКЕ ТАТАРСТАН}

ПАВЕЛ ВЛАДИМИРОВИЧ ТОКАРЕВ, врач челюстно-лицевой хирург высшей категории, зав. отделением челюстно-лицевой хирургии ГАУЗ «Детская республиканская клиническая больница», Казань, Россия, e-mail: facesurg@yandex.ru

АЛЕКСЕЙ ВЛАДИМИРОВИЧ ШУЛАЕВ, докт. мед. наук, проф., проректор ГБОУ ВПО «Казанский государственный медицинский университет» Минздрава России, Казань, Россия ЛЮДМИЛА ВИКТОРОВНА ПЛАКСИНА, канд. мед. наук, врач-педиатр, зав. отделением медико-социальной помощи детям подросткового возраста ГАУЗ «Детская республиканская клиническая больница», Казань, Россия, тел. +7(843) 267-89-52, e-mail: milaplax76@yandex.ru

Реферат. До настоящего времени остается актуальной проблема лечения детей с врожденными пороками развития челюстно-лицевой области в связи с отсутствием системы оказания комплексной специализированной помощи в Республике Татарстан. Цель - систематизировать этапы лечения и реабилитации врожденных расщелин губы и нёба, создать алгоритм комплексного подхода на основе существующих схем реабилитации и учета собственных методов обследования и лечения. Материал и методы. Исследование проводилось на базе отделения челюстно-лицевой хирургии ГАУЗ «Детская республиканская клиническая больница Министерства здравоохранения Республики Татарстан» (ДРКБ). Осуществлялся анализ данных диагностических исследований и сроков лечения из карт стационарного больного, паспорта беременной, паспорта новорожденного. Результаты и их обсуждение. Данный предложенный алгоритм комплексного подхода реабилитации детей с врожденной расщелиной верхней губы и нёба позволит качественно подготовить детей к оперативному лечению в более ранние сроки, тем самым снизит послеоперационные осложнения, улучшит функциональные результаты и качество жизни ребенка. Заключение. Полноценная медико-социальная адаптация может быть обеспечена только при соблюдении преемственности и этапности лечения.

Ключевые слова: врожденный порок развития челюстно-лицевой области; врожденная расщелина верхней губы, нёба; реабилитация детей с расщелинами губы и нёба, психологическая помощь детям с врожденными пороками развития челюстно-лицевой области, врожденные пороки.

\section{THE COMPLEX APPROACH IN TREATMENT OF CHILDREN WITH CONGENITAL LABIUM AND PALATE CLEFTS IN TATARSTAN REPUBLIC PRACTICE}

PAVEL V. TOKAREV, doctor fhighest category, maxillare facial surgeon, Head of the Department of maxillary facial surgery of SAlH «Children Republic Clinical Hospital», Kazan, Russia, e-mail: facesurg@yandex.ru

ALEXEY V. SHULAEV, Doctor of Medical Science, Professor, Pro-Rector of SBEI HPE «Kazan State Medical University» of Russian Ministry of Health, Kazan, Russia

LUDMILA V. PLAKSINA, Candidate of Medical Science, pediatrician, Head of the Department of SAIH "Children Republic Clinical Hospital», Kazan, Russia, e-mail: milaplax76@yandex.ru

Abstract. Introduction. The problem of treatment children with congenital maxillofacial region failure of development is actual nowadays, because of lack in complex specialized care system. Aim. To systemize the complex approach system in rehabilitation of children with this congenital defect, which was developed on previous rehabilitation scheme. Clinical-anatomical forms of clefts, patients somatic and neurological status, using own diagnostic and treatment methods were taken into account. This complex approach system in rehabilitation of children with congenital labium and palate 
clefts can allow to qualitatively prepare children to operative treatment in early period. It can reduce postoperative complications, improve function results. Conclusion. Full medical and social adaptation can be achieved only if the continuity and stages of treatment.

Key words: congenital maxillofacial region failure of development, congenital labium superior cleft, palate cleft, rehabilitation children with labium and palate cleft, psychological support to children with congenital maxillofacial region failure of development, congenital failures.

B ведение. Врожденная расщелина верхней губы и нёба является наиболее часто встречающимся пороком развития и занимает в структуре антенатальной патологии второе место. Среди аномалий развития челюстно-лицевой области эта патология занимает первое место [1]. У детей с данной врожденной патологией нарушается фрункция питания, дыхания, речеобразования, такие пациенты становятся инвалидами с раннего детства. Несмотря на успехи, достигнутые отечественными и зарубежными клиницистами в области реабилитации пациентов с врожденными расщелинами верхней губы и нёба, существенная часть проблем лечения данного контингента больных остается не решенной [2].

Необоснованность возрастных подходов и способов хирургической коррекции, несовершенство традиционных методов лечения, а главное, отсутствие преемственности на этапах комплексного дооперационного и послеоперационного лечения являются основными причинами неприемлемых эстетических и функциональных результатов. Также до настоящего времени отсутствуют система и своевременный учет всех родившихся детей с данной врожденной патологией и четкое, полное представление о совокупности проблем, которые присущи данным пациентам, неориентированность родителей и медицинского персонала в вопросах диспансеризации, специализированной помощи и социальной адаптации ребенка и членов его семьи.

Проблема лечения детей с врожденными расщелинами верхней губы и нёба требует специализированной комплексной медицинской помощи, включающей усилия специалистов различного профиля (неонатолога, педиатра, логопеда, оториноларинголога, ортодонта, хирурга, педагога, психолога, психиатра, сурдолога, реабилитолога и т.д.) [3]. Вместе с тем очевидно, что именно своевременное и правильное выполнение первичного хирургического лечения определяет успех комплексной реабилитации и социальной адаптации пациентов с врожденными расщелинами верхней губы и нёба [2]. Однако, каким бы совершенным ни был метод хирургического лечения, с его помощью невозможно устранить полностью анатомические и фрункциональные нарушения в детском организме, вызываемые данным пороком развития, и решить все вопрось социальной и психологической реабилитации ребенка. В настоящее время единственно правильным является комплексный подход к лечению этих детей в условиях специализированных центров и в диспансерном регламенте. В условиях продолжающегося реформирования системы здравоохранения специализированные центры реабилитации должны стать основным связующим звеном между семьей, имеющей ребенка с проблемами здоровья, и системой государственной поддержки [3, 4].

Цель - систематизировать этапы лечения и реабилитации врожденных расщелин губы и нёба в алгоритм комплексного подхода на основе существующих схем реабилитации и учета собственных методов обследования и лечения.

Материал и методы. Исследование проводилось на базе отделения челюстно-лицевой хирургии ГАУЗ «Детская республиканская клиническая больница Министерства здравоохранения Республики Татарстан» (ДРКБ). Осуществлялся анализ данных диагностических исследований и сроков лечения из карт стационарного больного, паспорта беременной, паспорта новорожденного.

Результаты и их обсуждение. До настоящего времени в Республике Татарстан отсутствует специализированный центр для детей с врожденными пороками челюстно-лицевой области. Специализированную медицинскую помощь пациентам с врожденными пороками развития челюстно-лицевой области оказывают в отделение челюстно-лицевой хирургии ДРКБ. Данная медицинская организация является третьим (федеральным) уровнем здравоохранения республики по оказанию медикосанитарной помощи. В Республике Татарстан, по нашим исследованиям, средний уровень частоты врожденных расщелин губы и нёба на протяжении периода с 2002 по 2012 г. составил 2,2 на 1000 новорожденного.

К настоящему времени как в России, так и за рубежом уже разработан и утвержден базовый алгоритм по ведению детей с врожденными расщелинами губы и нёба. За основу алгоритма нами взяты схемы реабилитации детей с врожденной расщелиной губы и нёба С.В. Дьяковой (2002) и О.И. Блохиной (1992), в которые мы ввели дополнительные реабилитационные мероприятия, адаптированные к условиям нашего региона. Реабилитация осуществляется в течение всего периода детства - от 0 до 18 лет, а у некоторых пациентов и в более поздние сроки. Этапы реабилитации мы разделили в соответствии с периодами детства, утвержденными в педиатрической практике, на 7 периодов (таблица).

Ведущая роль в лечение и реабилитации детей принадлежит челюстно-лицевому хирургу и ортодонту как на дооперационном этапе, так и в послеоперационном периоде. Именно эти специалисты планируют все виды и объем лечения, их очередность и продолжительность в зависимости от степени тяжести врожденного порока.

\section{I период - антенатальный}

1. Проведение УЗИ беременным женщинам на 22-й нед в женских консультациях. 
Периоды детства

\begin{tabular}{|c|c|c|c|c|c|c|}
\hline $\begin{array}{c}\text { Пренатальный } \\
\text { (антенатальный } \\
\text { период }\end{array}$ & $\begin{array}{c}\text { Период } \\
\text { новорожден- } \\
\text { ности }\end{array}$ & $\begin{array}{c}\text { Период } \\
\text { грудного } \\
\text { возраста }\end{array}$ & $\begin{array}{c}\text { Период } \\
\text { ясельного } \\
\text { возраста }\end{array}$ & $\begin{array}{c}\text { Дошкольный } \\
\text { период }\end{array}$ & $\begin{array}{c}\text { Период } \\
\text { младшего } \\
\text { школьного } \\
\text { возраста }\end{array}$ & $\begin{array}{c}\text { Период } \\
\text { старшего } \\
\text { школьного } \\
\text { возраста }\end{array}$ \\
\hline- & $\begin{array}{c}\text { До 1 месяца } \\
\text { жизни }\end{array}$ & $\begin{array}{c}\text { С 1 мес } \\
\text { до 1 года }\end{array}$ & $\begin{array}{c}\text { С 1 года } \\
\text { до 3 лет }\end{array}$ & С 3 до 6 лет & С 7 до 10 лет & С 10 до 18 лет \\
\hline
\end{tabular}

2. Выявление групп риска беременных, у которых выявлен плод с врожденным пороком развития челюстно-лицевой области.

3. Консультация генетика с целью исключения сопутствующего генетического синдрома и профилактика повторных рождений детей с врожденными пороками. Также инициируется врачебный консилиум для решения вопроса о досрочном прерывании беременности при тяжелых сопутствующих пороках развития других органов и систем.

4. Медико-психологическое и медико-социальное консультирование беременных: челюстно-лицевой хирург, педиатр, психолог, при необходимости другие узкие специалисты. Беременную и ее семью подготавливают к рождению ребенка с врожденной патологией челюстно-лицевой области.

II период - новорожденности:

1. Обследование у челюстно-лицевого хирурга, неонатолога, педиатра, оториноларинголога, невролога, ортодонта.

2. Диагностика сопутствующей патологии и других пороков развития.

3. Планирование индивидуальной комплексной программы лечения и реабилитации. Установление сроков, тактики и объема хирургического вмешательства.

4. Лечение сопутствующей патологии других органов и систем другими специалистами с целью подготовки к оперативному лечению в индивидуальные сроки.

5. Индивидуальное консультирование медицинского психолога, при необходимости - специалиста по социальной работе и юриста.

6. Введение в отделение челюстно-лицевой хирургии мониторинга пациентов с врожденным пороком, обратившихся в Детскую республиканскую клиническую больницу РТ.

После рождения все дети с врожденной патологией челюстно-лицевой области консультируются челюстно-лицевым хирургом сразу в родильном доме (при генетических синдромах, в симптомокомплекс которых входит гипоплазия нижней челюсти, сопровождающаяся синдромом внезапной остановки дыхания, при тяжелой степени сквозной расщелины верхней губы и нёба и др.) или в первый месяц жизни ребенка, который выставляет правильный полный диагно3, планирует сроки, тактику и объем хирургического лечения. Далее ребенок осматривается бригадой специалистов. Педиатром производится оценка соматического статуса, индивидуально выбирается вид вскармливания и объем питания, оценивается микрофрлора полости рта, иммунный статус и осуществляется подготовка к хирургическому лечению в течение первого года жизни. Проводится индивидуальная работа с каждой семьей по обучению особенностям выхаживания, кормления для обеспечения оптимального удовлетворительного развития ребенка с врожденной расщелиной губы и нёба. При сочетанной патологии ребенок осматривается узкими специалистами (неврологом, эндокринологом, кардиологом и др.), даются соответствующие рекомендации, при необходимости проводится лечение. На дооперационном этапе осуществляется ортодонтическое лечение детей с врожденными расщелинами альвеолярного отростка. При согласии матери (родителей) проводится амбулаторное консультирование медицинского психолога с момента рождения до окончания реабилитации с целью поддержания и снижения возникшей тревоги за будущего ребенка с врожденной расщелиной губы и нёба, какова степень реальной ответственности. Психолог помогает родителям обрести самих себя как хороших, любящих своего ребенка родителей. И как результат такой длительной работы - это уменьшение личностной патологии пациента, социализация ребенка и абсолютная адаптация в обществе. В ДРКБ в отделении медико-социальной помощи детям имеется специалист по социальной работе и юрист. При определенных трудностях детям и их семьям оказывается социальная и правовая поддержка.

III период - грудной возраст:

1. Предоперационное ортодонтическое лечение (аппаратурное лечение, направленное на нормализацию положения фрагментов альвеолярного отростка).

2. Хирургическое лечение (первичная хейлоринопластика) с 3-месячного возраста.

3. Послеоперационное наблюдение педиатра.

4. Послеоперационная реабилитация, противорубцовая терапия.

5. Логопедическое лечение.

6. Ортодонтическое лечение.

Хирургическое лечение начинается с 3 мес жизни при удовлетворительном соматическом и неврологическом статусе. При расщелинах верхней губы выполняется первичная хейлопластика или хейлоринопластика (при двусторонней расщелине верхней губы - хейлопластика в один этап). Цель раннего дооперационного ортодонтического лечения - устранение смещения фрагментов верхней челюсти при расщелине альвеолярного отростка и предупреждение вторичного смещения в послеоперационном периоде. При сопутствующих заболеваниях других органов и систем осуществляется лечение узкими специалистами. Проводится консультирование иммунолога, особенно часто болеющих детей. В послеоперационном периоде действия педиатра направлены на восстановление соматического статуса, функциональных способ- 
ностей оперированных тканей, профилактику возникновения хронических заболеваний и острых инфекционных процессов у ребенка.

IV период - ясельный возраст:

1. Предоперационная подготовка педиатра к щадящей уранопластике.

2. Консультация сурдолога с применением аппаратных методов исследования.

3. Ортодонтическое предоперационное лечение, которое препятствует сужению зубного ряда и уплощению нёба.

4. Стоматологическое лечение.

5. Щадящая уранопластика с 12 мес жизни.

6. Послеоперационный период.

7. Противорубцовая терапия, электростимуляция, фризиотерапия, лазеротерапия.

8. Реконструктивная хейлоринопластика (по показаниям).

9. Логопедическое лечение, направленное на развитие нижнереберного дыхания, фронематического слуха и постановку звуков.

С 12 мес жизни ребенка при массе тела 10 кг и более проводится щадящая уранопластика одномоментно твердого и мягкого нёба. Педиатр осуществляет подготовку к оперативному лечению расщелины нёба. Оценивается микрофрлора полости рта, при необходимости проводится этиотропная терапия с целью минимизирования послеоперационных осложнений. Также санируются хронические очаги инфекции и лечение сопутствующей патологии соматического статуса. Послеоперационная реабилитация направлена на восстановление функции нёбно-глоточного кольца и фрормирование речи. С 2-летнего возраста по индивидуальным показаниям, при наличии грубой рубцовой деформации и сужении крыла носа проводится коррекция верхней губы и крыла носа (реконструктивная хейлоринопластика).

\section{V период - дошкольный возраст:}

1. Лечение у педиатра, стоматолога, оториноларинголога не менее 3 раз в год.

2. Хирургическая коррекция послеоперационных дефектов после уранопластики и нёбно-глоточной недостаточности (по показаниям).

3. Послеоперационное реабилитационное лечение - фризиотерапия, лазеротерапия, противорубцовое лечение, электростимуляция

4. Ортодонтическое (аппаратурное) лечение, препятствующее сужению и уплощению верхнего зубного ряда.

5. Логопедическое лечение, которое направлено на развитие подвижности оперированного нёба

6. Наблюдение психолога, педагога, специалиста по социальной работе.

7. Лечение в реабилитационных центрах при сопутствующей патологии.

В 6 лет по показаниям проводится коррекция нёбно-глоточной недостаточности. Активно работает логопед над фрормированием нижнереберного дыхания, фронематического слуха и постановкой звуков, а также психолог-педагог и медицинский психолог.

VI период - младший школьный возраст:

1. Обследование, лечение у педиатра, оториноларинголога, стоматолога 3 и более раз в год.
2. Консультация сурдолога.

3. Подготовка к оперативному лечению.

4. Хирургическое лечение - костная пластика альвеолярного отростка с 9 лет.

5. Коррекция нёбно-глоточной недостаточности (по показаниям).

6. Ортодонтическое (аппаратурное) лечение, направленное на нормализацию положения постоянного ряда зубов верхней челюсти.

7. Корригирующая хейлоринопластика (по показаниям).

8. Логопедическое лечение, направленное на коррекцию и автоматизацию голосовых навыков.

9. Психолого-педагогическая реабилитация.

10. Лечение в детских реабилитационных центpax.

VII период - старший школьный возраст:

1. Обследование и лечение у педиатра, стоматолога, оториноларинголога не менее 3 раз в год.

2. Консультация иммунолога и других специалистов по показаниям.

3. Реконструктивная хейлоринопластика при остаточных деформациях носа.

4. При наличии больших дефектах переднего отдела твердого нёба - уранопластика лоскутом с языка.

5. Пластика верхней губы по Аббе (при грубой рубцовой деформации верхней губы и двусторонних расщелинах)

6. Ортодонтическое (аппаратурное) лечение.

7. Психолого-педагогическая реабилитация с коррекцией психосоматических нарушений.

В период гормональной перестройки организма ребенок с врожденной патологией челюстно-лицевой области в послеоперационном периоде должен быть фризически и социально-психологически адаптирован в обществе. Не совсем обычная внешность подростка может привести к нежелательным последствиям. Поэтому каждый ребенок требует индивидуального подхода к своей проблеме на протяжении всего периода реабилитации.

Выводы. Таким образом, оперативное лечение в ранние сроки является важнейшим этапом планового лечения пациента с врожденным пороком развития челюстно-лицевой области. В системе реабилитации также важное значение имеют мероприятия, направленные на подготовку ребенка к операции, восстановление его соматического, неврологического и психологического статусов, на сохранение функциональных способностей оперированных тканей, профилактику вторичных деформаций челюстно-лицевой области и уменьшение личностной патологии детей с данной врожденной патологией. Полноценная медико-социальная адаптация может быть обеспечена только при соблюдении преемственности и этапности лечения. Предложенный нами алгоритм комплексного лечения детей с врожденной патологией челюстно-лицевой области разработан с учетом клинико-анатомических форм дефектов, фракторов окружающей среды, применения собственных методов обследования и лечения, что позволяет снизить послеоперационные осложнения, улучшить анатомо-фрункциональные 
результаты и качество жизни ребенка и добиться максимальной медико-психологической и медикосоциальной реабилитации.

\section{ЛИТЕРАТУРА}

1. Блохина, С.И. Медико-социальная реабилитация больных с врожденными расщелинами лица и нёба в условиях специализированного центра: автореф. дис. ... д-ра мед. наук / Блохина Светлана Ивановна. - М., 1992. - 49 c.

2. Гончаков, Г.В. Комплексная реабилитация детей с врожденными расщелинами верхней губы и нёба в НПЦ медицинской помощи детям / Г.В. Гончаков // Врожденная и наследственная патология головы, лица и шеи у детей: актуальные вопросы комплексного лечения: материалы II Всерос. науч.-практ. конф. — М., 2006. - C.48-49.

3. Дьякова, С.В. Современный подход к диспансеризации детей с врожденной патологией челюстно-лицевой области / С.В. Дьякова, С.В. Яковлева, М.А. Першина // Врожденная и наследственная патология головы, лица и шеи у детей: актуальные вопросы комплексного лечения: материалы II Всерос. науч.-практ. конфр. - М., 2006. - C.85-88.

4. Kobrynski, L.J. Velocardiofacial syndrome, DiGeorgesyndrome: the chromosome 22q11.2 deletion syndromes / L.J. Kobrynski, K.E. Sullivan // Lancet. - 2007. Vol. 370(9596). - P.1443-1452.

5. Stickler syndrome: clinical characteristics and diagnostic criteria / P.S. Rose, H.P. Levy, R.M. Liberfarb [et al.] // Am. J. Med. Genet. — 2005. — Vol. 138(3). — P.199-207.

\section{REFERENCE}

1. Blohina, S.I. Mediko-social'naya reabilitaciya bol'nyh s vrozhdennymi rasschelinami lica i nyoba v usloviyah specializirovannogo centra [Medical and social rehabilitation of patients with congenital facial cleft and palate in a specialized center]: avtoref. dis. ... d-ra med. nauk / Blohina Svetlana Ivanovna. - M., 1992. $49 \mathrm{~s}$.

2. Gonchakov, G.V. Kompleksnaya reabilitaciya detei s vrozhdennymi rasschelinami verhnei guby i nyoba $v$ NPC medicinskoi pomoschi detyam [Comprehensive rehabilitation of children with congenital cleft lip and palate in the NPC health care for children] / G.V. Gonchakov // Vrozhdennaya i nasledstvennaya patologiya golovy, lica i shei u detei: aktual'nye voprosy kompleksnogo lecheniya: materialy II Vseros. nauch.-prakt. konf. [Congenital and hereditary diseases of the head, face and neck in children: current issues of comprehensive treatment: Materials II All-Russia. scientific and practical. conf.]. — M., 2006. S.48-49.

3. D'yakova, S.V. Sovremennyi podhod k dispanserizacii detei s vrozhdennoi patologiei chelyustno-licevoi oblasti [The modern approach to clinical examination of children with congenital pathology of maxillofacial area] / S.V. D'yakova, S.V. Yakovleva, M.A. Pershina // Vrozhdennaya i nasledstvennaya patologiya golovy, lica i shei u detei: aktual'nye voprosy kompleksnogo lecheniya: materialy II Vseros. nauch.-prakt. konf. [Congenital and hereditary diseases of the head, face and neck in children: current issues of comprehensive treatment: Materials II All-Russia. scientific and practical. conf.]. - M., 2006. S.85-88.

4. Kobrynski, L.J. Velocardiofacial syndrome, DiGeorgesyndrome: the chromosome 22q11.2 deletion syndromes / L.J. Kobrynski, K.E. Sullivan // Lancet. - 2007. Vol. 370(9596). - P.1443-1452.

5. Stickler syndrome: clinical characteristics and diagnostic criteria / P.S. Rose, H.P. Levy, R.M. Liberfarb [et al.] // Am. J. Med. Genet. — 2005. — Vol. 138(3). — P.199-207. 


\section{ЗАКРЫТАЯ ТРАВМА СЕРДЦА НА ДОГОСПИТАЛЬНОМ ЭТАПЕ}

АЛСУ ИЛЬДУСОВНА АБДРАХМАНОВА, канд. мед. наук, доцент кафедры кардиологии, рентгеноэндоваскулярной и сердечно-сосудистой хирургии ГБОУ ДПО «Казанская государственная медицинская академия» Минздрава России, Казань, Россия, тел. 8-917-922-66-29, e-mail: alsuchaa@mail.ru

НАИЛЬ БАГАУВИЧ АМИРОВ, докт. мед. наук, профессор кафедры общей врачебной практики ГБОУ ВПО «Казанский государственный медицинский университет» Минздрава России, Казань, Poccия, e-mail: namirov@mail.ru НИКОЛАЙ АНАТОЛЬЕВИЧ ЦИБУЛЬКИН, канд. мед. наук, доцент кафедры функциональной диагностики ГБОУ ДПО «Казанская государственная медицинская академия» Минздрава России, Казань, Россия

Реферат. Цель исследования - анализ последних публикаций по проблеме закрытой травмы сердца. Материал и методы. Осуществлен обзор публикаций в научной и медицинской литературе, посвященных этиологии, патогенезу, диагностике, дифференциальной диагностике и консервативному лечению закрытой травмы сердца. Произведен анализ современного состояния взглядов на происхождение данной патологии, раскрываются ведущие механизмы развития симптомов и клинической картины заболевания, приводятся наиболее распространенные клинические варианты закрытой травмы сердца, такие как посттравматическая миокардиодистрофия, повреждение магистральных сосудов, острая клапанная недостаточность, разрыв миокарда, травматический инфаркт миокарда, ушиб сердца, сотрясение сердца. Большое внимание уделено классификации основных клинических проявлений заболевания по стадиям и тяжести течения, а также по характеру морфологических нарушений. Рассмотрены основные лечебные мероприятия по контролю состояния пациента и восстановления нормального функционирования сердечной мышцы после перенесенной травмы, включающие купирование болевого синдрома, борьбу с нарушениями ритма и проводимости, нормализацию гемодинамики, восстановление сократительной функции миокарда, улучшение метаболизма мышцы сердца, а также вопросы прогноза при закрытой травме сердца. Выводы. Закрытая травма сердца часто сопутствует повреждениям грудной клетки. В условиях нарушения сознания и травматического шока диагностика этого заболевания представляет значительные трудности. Высокая частота поздней диагностики приводит к задержке начала показанного лечения и повышенной летальности. Закрытая травма сердца имеет различные клинические проявления на разных стадиях ее течения.

Ключевые слова: сердце, закрытая травма, диагностика, лечение.

\section{CLOSED HEART INJURY ON THE PREHOSPITAL}

ALSU I. ABDRAKHMANOVA, Candidate of Medical Science, associate professor of the Department of cardiology, roentgen-endovascular and cardiovascular surgery of SBEI APE «Kazan State Medical Academy» of Russian Ministry of Health, Kazan, Russia, tel. 8-917-922-66-29, e-mail: alsuchaa@mail.ru

NAIL B. AMIROV, Doctor of Medical Science, Professor of the Department of general medical practice of SBEI HPE «Kazan State Medical University» of Russian Ministry of Health, Kazan, Russia, e-mail: namirov@mail.ru NIKOLAI A. TSIBULKIN, Candidate of Medical Science, associate professor of the Department of functional diagnostics of SBEI APE «Kazan State Medical Academy» of Russian Ministry of Health, Kazan, Russia

Abstract. Aim. To analyze the last publications on the closed heart injury. Material and methods. To review the publications on etiology, pathogenesis, diagnostics, differential diagnostics and conservative treatment of closed heart injury. We analyzed the current state of this pathology: the leading mechanisms of signs and symptoms development. The most widespread clinical options of the closed heart injury were given: post-traumatic myocardial dystrophy, main vessels damage, sharp valve insufficiency, a myocardium rupture, a traumatic myocardial infarction, a heart bruise and heart concussion. Much attention was paid to classification by stages and clinical state, and by morphological disorders. We reviewed the state control measures and restoration of normal functioning of a cardiac muscle after the postponed trauma including rapid pain relief, arrhythmia attack and abnormal conductivity treatement, normalization of hemodynamic, restoration of contraction function of myocardium, myocardium metabolism improvement, and also prognosis for outcome. Conclusions. The closed heart injury often accompanies thorax injuries. Unconsciousness and traumatic shock complicate diagnosis. High frequency of late diagnostics delays the treatment and raise lethality. The closed heart injury has various clinical manifestations at different stages of the disease.

Key words: heart, closed trauma, diagnostics, treatment.

3 акрытые травмы грудной клетки в 70\% случаев сопровождаются повреждением сердца, которое приводит к летальным исходам у 45-62\% пациентов [21, 22]. Причиной летального исхода при травмах сердца часто являются аритмии, возникаю- щие вследствие тяжелого повреждения миокарда. Поздняя диагностика травмы сердца достигает 55\% случаев и связана с тяжестью сочетанной травмы. Нередко закрытые травмы сердца выявляются только при патолого-анатомическом исследовании. 
В этой связи диагностика и лечение закрытых травм сердца является актуальной клинической проблемой $[8,12,13]$.

Закрытая травма сердца (ЗТС) - это группа повреждений сердца в результате действия травматического фрактора. Закрытые повреждения сердца подразделяют на первично-травматические, которые возникают сразу после травмы или в ближайший период после травмы, и вторично-травматические поражения сердца, развивающиеся в результате метаболических нарушений как последствие травмы $[1,17,29]$.

Патогенез. В патогенезе ЗТС выделяют пять ведущих фракторов: 1) внезапное сдавливание сердца с повышением давления в его полостях; 2) внезапный удар в область сердца с его повреждением отломками ребер; 3) смещение сердца при ушибе грудной клетки; 4) стрессовое влияние центральной нервной системы (ЦНС) на сердце; 5) нарушение метаболизма в миокарде в результате политравмы [14, 18, 23]. Тяжесть ЗТС зависит от многих причин: характера травмы, фразы сердечной деятельности в момент травмы, состояния миокарда и коронарных сосудов до травмы и пр. Наибольшее повреждение миокарда возникает при нанесении травмы в переднезаднем направлении, что приводит к кровоизлиянию в миокард или к разрыву его стенок. При ЗТС наблюдаются кровоизлияния, дистрофические и некротические изменения в миокарде, а также снижение уровня гликогена и активности сукцинатдегидрогеназы в кардиомиоцитах с повышением уровня молочной кислоты, достигающего максимума (в 7-8 раз выше нормы) через 3-4 ч после травмы [14, 16, 24, 25].

Возможными механизмами развития сердечной смерти у лиц, перенесших ЗТС, являются апноэ, глубокий вазовагальный рефлекс или первичная фибрилляция желудочков (ФЖ), которая в настоящее время рассматривается как наиболее вероятный механизм. ФЖ часто возникает при травме сердца и может быть вызвана физическим воздействием на грудную клетку в области проекции сердца, особенно в проекции центральной части левого желудочка $[15,23]$.

При механической травме, не сопровождающейся грубым повреждением жизненно важных органов, предполагаются два типа остановки сердца.

Первый тип имеет преимущественно вагусный механизм и возникает в случаях, когда при сильном ударе в рефлексогенную зону (области каротидного узла, солнечного сплетения, печени, передняя поверхность грудной клетки в проекции сердца) раздражается большое количество элементов блуждающего нерва, в результате чего одновременно формируется большое число импульсов. Это вызывает подавление функции водителей ритма в синоатриальном (CA) и атриовентрикулярном (AB) узлах с их выраженным угнетением вплоть до остановки, что приводит к развитию асистолии, которая прерывается синусовым ритмом либо переходит в ФЖ или необратимую атонию миокарда. Большое число нервных окончаний блуждающего нерва, сосредоточенных в перикарде и эпикарде, испытывают чрезмерное раздражение на участках, где сердце не прикрыто легкими. Сильный удар в грудь может также привести к значительному смещению сердца и перерастяжению сосудистого пучка, в результате чего возникает сильная вагусная импульсация, создающая условия для остановки сердца. Реакция сердца на вагусное раздражение различна, и то раздражение, которое у одних вызывает брадикардию и заканчивается благополучно, у других может вызвать асистолию.

Второй тип остановки кровообращения при ЗТС реализуется через фибрилляцию желудочков, и здесь также выделяют два варианта. Во-первых, это может быть прямое воздействие на область сердца, которое провоцирует электрический ответ и само может вызывать ФЖ при попадании в «уязвимый период». Катехоламины, выделяющиеся при стрессе, также усиливают электрическую нестабильность миокарда во время «уязвимого» периода. В то же время этот вариант встречается не часто, так как «уязвимый» период занимает только $2-3 \%$ сердечного цикла, и не каждый стимул, попадающий на этот период, приводит к фибрилляции. Во-вторых, остановка кровообращения при механической травме сердца может быть связана с изменениями в коронарных артериях, ведущими к острой ишемии миокарда с последующей ФЖ [18, 19, 20, 26].

Клиническая картина. Клиническими проявлениями ЗТС чаще всего бывают сотрясение или ушиб сердца, разрыв миокарда и травматический инфаркт миокарда [9, 10, 23].

Сотрясение сердца нередко дебютирует аритмиями в виде экстрасистолии, фибрилляции или трепетания предсердий, либо брадикардии и нарушения проводимости. Боль наблюдается редко и непродолжительно, характерна бледность, снижение артериального давления, глухость сердечных тонов. Эти признаки могут наблюдаться в течение нескольких часов. Этому сопутствуют церебральные нарушения: головокружение, нарушение мышечного тонуса, расстройство сознания [25, 27]. В $50 \%$ случаев коллапс развивается немедленно, но может возникнуть после короткого периода сохранения сознания [15]. На электрокардиограмме (ЭКГ) определяются изменения субэпикардиальной локализации и нарушения сердечного ритма.

Диффреренциальная диагностика при ЗТС проводится с другими состояниями, приводящими к ФЖ: аномалии коронарных артерий, гипертрофическая кардиомиопатия, аритмогенная дисплазия правого желудочка, синдром удлиненного интервала QT, инфаркт миокарда, вирусный миокардит. Ключевыми для диагностики являются связь симптомов с ударом в грудную клетку и отсутствие в сердце изменений, способных стать причиной смерти [9, 18-20].

Уииб сердца сопровождается следующими признаками [7, 21, 22]: возникновение боли, имитирующей стенокардию, в месте ушиба или за грудиной; сердцебиение, общая слабость, одышка, бледность, акроцианоз; нарушение ритма (тахикардия, брадикардия, экстрасистолия); пульс слабого наполнения, давление лабильно, с тенденцией к снижению систолического (до 80-90 мм рт.ст.) и пульсового (до 10-20 мм рт.ст.); возможны приглушение тонов, 
систолический шум на верхушке сердца, ритм галопа, шум трения перикарда. На ЭКГ возможны синусовая тахи- или брадикардия, предсердная или желудочковая экстрасистолия, фрибрилляция предсердий (ФП) или трепетание предсердий (ТП), различные тахикардии, атриовентрикулярные блокады, нарушения внутрижелудочковой проводимости признаки ишемии и метаболических расстройств [2, 5, 21, 22]. Острый период ушиба сердца может осложниться кардиогенным шоком, протекающим на фоне травматического шока. На 3-10-е сут после травмы, после стабилизации или улучшения состояния вновь нарастают клинические и ЭКГ-признаки поражения миокарда, обусловленные развитием глубоких дистрофических и воспалительных изменений в зонах кровоизлияния.

Предложена классификация ушибов сердца (Марчук В.Г. и др., 2012), позволяющая унифицировать их клиническую оценку [11]:

1. По тяжести:

- легкая: без нарушений гемодинимики, быстро проходящие нарушения ритма и проводимости, выраженные изменения на ЭКГ;

- средней тяжести (стенокардитическая): стойкие нарушения ритма и проводимости, преходящие нарушениями гемодинамики;

- тяжелая (инфрарктоподобная): стойкие и прогрессирующие нарушения гемодинамики.

2. По стадиям течения:

- первично-травматические нарушения (первые трое суток);

- травматический миокардит (до 25 сут);

- восстановление нарушенных функций (до 25 сут);

- исход.

3. По характеру морорологических нарушений:

- 1-й период - острый (2-3-и сут);

- 2-й период - репаративная регенерация (до 14 сут);

- 3-й период - посттравматический кардиосклероз (более 14 сут).

Травматический инфаркт миокарда встречается у пожилых людей даже при падении на край тротуара. На фоне измененных коронарных артерий он протекает более тяжело: наблюдаются интенсивные загрудинные боли сразу после травмы, нарушения ритма, кардиогенный шок. Характерны бледность, цианоз, холодный пот, тахикардия, пульс слабого наполнения, гипотония. Тоны сердца глухие, систолический шум с максимальной интенсивностью на верхушке. В остром периоде на ЭКГ подъем сегмента ST, патологический зубец Q над зоной поражения, различные нарушения ритма и проводимости. Течение может осложняться сердечной астмой и отеком легких. При ЗТС возможна отслойка интимы коронарных артерий, что ведет к инфаркту при отсутствии атеросклероза [5].

Разрыв миокарда может быть внешним и внутренним [4]. При внешних разрывах возникает сообщение с перикардом, что приводит к быстрому летальному исходу. В случае оказания экстренной кардиохирургической помощи возможен благоприятный исход. Клиническим признаком внешнего разрыва является гемотампонада. Пострадавшие бледные, с выраженной одышкой, нитевидным пульсом, коллапсом, границы сердца широкие. Могут быть тяжелые нарушения ритма. Сопутствующий разрыв перикарда приводит к кровотечению в грудную полость.

При внутренних разрывах нарушается целостность межжелудочковой или межпредсердной перегородки, повреждаются клапаны, сухожильные нити, папиллярные мышцы. Характерна одышка, цианоз, тахикардия, гипотония, грубый систолический шум. Возможно появление острой правожелудочковой (при дефекте межжелудочковой перегородки) или левожелудочковой (при повреждении папиллярных мышц или створок митрального клапана) сердечной недостаточности $(\mathrm{CH})$, сочетающейся с травматическим шоком. Прогноз часто неблагоприятный.

Острая клапанная недостаточность возникает вследствие повреждения клапанов, папиллярных мышц, хорд и характерна для исходно измененных клапанов. Наиболее уязвим аортальный клапан. Повреждение клапанов можно предположить при появлении шума, артериальной гипотензии, нарастающем отеке легких. Пансистолический шум появляется также при разрыве межжелудочковой перегородки в сочетании с появлением блокады правой ножки пучка Гиса или отклонением электрической оси сердца вправо. Острая трикуспидальная регургитация переносится лучше и проявляется отеками ног и асцитом.

Повреждение магистральных сосудов. Аорта часто страдает при ЗТС в виде ее надрыва или разрыва, что чаще всего приводит к летальному исходу. Разрыв аорты обычно происходит в нисходящем отделе, где она прикреплена к позвоночнику за счет межреберных артерий. Характерна боль в спине, гипотензия, ослабление пульса на ногах и его усиление на руках.

Посттравматическая миокардиодистрофия возникает часто, в ней выделяют 3 периода: острый (3-5 дней), подострый (7-14 дней), восстановительный (от 15-30 дней до 1-2 мес). Возможно полное выздоровление, но часто в дальнейшем возникают аритмии или стенокардия. Характерно появление нарушений ритма, глухих тонов, нарушений центральной гемодинамики [10]. В диагностике имеет значение тщательно собранный анамнез и анализ механизма травмы. Обнаружение следов травмы грудной клетки (ссадин, кровоподтеков, подкожной эмфиземы) способствует диагностике [6, 28].

Консервативное лечение. Экстренная помощь при ЗТС на догоспитальном этапе и в стационаре проводится по следующим направлениям $[9,28]$

1) купирование болевого синдрома;

2) борьба с нарушениями ритма и проводимости;

3) нормализация гемодинамики;

4) восстановление сократительной функции миокарда;

5) улучшение метаболизма мышцы сердца.

Для купирования болевого синдрома используется как препарат выбора морфин, если нет доку- 
ментального подтверждения гиперчувствительности к нему. Морфин не только обезболивает, но и уменьшает чувство страха, возбуждение у пациента, снижает симпатическую активность, увеличивает тонус блуждающего нерва, уменьшает работу дыхания, вызывает расширение периферических артерий и вен. Доза, которая необходима для адекватного обезболивания, в ряде случает индивидуальна. Перед использованием 10 мг морфина гидрохлорида или сульфата разводят в 10 мл 0,9\% раствора хлорида натрия или дистиллированной воды, вводят внутривенно (в/в) медленно 2-4 мг лекарственного вещества, до купирования боли или возникновения побочных эффректов, продолжают введение каждые 5-15 мин по 2-4 мг. На фоне введения морфина возможна выраженная артериальная гипотензия (устраняется приведением больного в горизонтальное положение в сочетании с поднятием ног, если нет отека легких). Если этого недостаточно, то в/в вводится 0,9\% раствор хлорида натрия или другие плазмоэкспандеры, в редких случаях - прессорные препараты. Выраженная брадикардия в сочетании с артериальной гипотензией устраняется атропином (в/в 0,5-1,0 мг); тошнота, рвота устраняются производными фенотиазина, в частности метоклопрамидом (в/в 5-10 мг); выраженное угнетение дыхания устраняется налоксоном (в/в 0,1-0,2 мг, при необходимости повторно каждые 15 мин), однако при этом уменьшается анальгезирующее действие препарата [3].

Предложены также другие способы обезболивания, в частности внутривенное введение 25-50 мг (1-2 мл) дроперидола и 0,05-0,1 мг (1-2 мл) френтанила в 20 мл 5-40\% раствора глюкозы (можно внутримышечно или подкожно) при отсутствии признаков угнетения дыхания. Закись азота в смеси с кислородом (в соотношении от 4:1 до 1:1), если нет признаков расстройства дыхания.

При аритмиях без снижения артериального давления на догоспитальном этапе антиаритмическая терапия не проводится. Если ФП или ТП устойчивы и протекают на фоне артериальной гипотензии, выраженной $\mathrm{CH}$, тяжелой ишемии миокарда, то оптимальный метод лечения - синхронизированная с зубцом R электрическая кардиоверсия. Энергия монофазного разряда составляет, как минимум, 200 Дж для ФП или 50 Дж для ТП; при необходимости энергию разряда увеличивают на 100 Дж вплоть до 400 Дж. В случае использования разряда двухфазной формы его величину снижают примерно наполовину. Чтобы уменьшить повреждение миокарда, интервалы между электрическими разрядами не должны быть менее 1 мин. Процедуру проводят на фоне кратковременного наркоза или в/в введения седативных препаратов. В случае неэффективности электрической кардиоверсии или быстром возобновлении аритмии показаны антиаритмические препараты. Предпочтительно в/в введение амиодарона в дозе 300 мг (или 5 мг/кг) за 10-60 мин, в последующем при необходимости повторно по 150 мг каждые 10-15 мин или суточная инфузия препарата в дозе 900 мг (при необходимости на фоне инфузии возможны дополнительные введения препарата по
150 мг). Общая доза за сутки не должна превышать 2,2 г. На любом этапе введение амиодарона должно быть прекращено при увеличении продолжительности интервала QT более 500 мс.

Для устранения устойчивого пароксизма суправентрикулярной тахикардии могут использоваться следующие подходы: в/в введение аденозина (6 мг за 1-2 с, при сохранении аритмии через 1-2 мин 12 мг, при необходимости через 1-2 мин еще 12 мг); в/в введение $\beta$-адреноблокаторов (метопролола до 15 мг, пропранолола до 10 мг дробно за несколько приемов); в/в введение дилтиазема 20 мг (0,25 мг/ кг) за 2 мин с последующей инфузией 10 мг/ч; в/в введение дигоксина 8-15 мкг/кг (0,6-1,0 мг у больного весом 70 кг), половина дозы сразу, оставшаяся дробно в последующие 4 ч.

Методика нанесения электрических разрядов для устранения устойчивой полиморфной желудочковой тахикардии (ЖТ), сопровождающейся остановкой кровообращения или нарушением гемодинамики, такая же, как при ФЖ. Используются не синхронизированные с зубцом R электрические разряды большой энергии, как при ФЖ. При устойчивой полиморфной ЖТ необходимо устранить ишемию миокарда и чрезмерную адренергическую активность ( $\beta$-блокаторы), нормализовать уровень калия и магния в крови. У больных с частотой сердечных сокращений (ЧСС) менее 60 в мин при синусовом ритме или удлиненном корригированном интервале QT может быть начата временная электрокардиостимуляция (ЭКС) для учащения ритма желудочков.

Эпизоды устойчивой мономорфной ЖТ, сопровождающейся стенокардией, усугублением СН или снижением АД менее 90 мм рт.ст., устраняются синхронизированным с зубцом R электрическим разрядом на фоне кратковременного наркоза или в/в введения седативных препаратов. Начальная энергия монофазного разряда составляет 100 Дж. При неэффективности первой попытки энергию разряда увеличивают до 200, а затем при необходимости до 300 и 360 Дж. Неотложная кардиоверсия обычно не нужна при ЖТ с частотой менее 150 в мин, не вызывающей нарушений гемодинамики.

Устойчивая мономорфная ЖТ, не провоцирующая ангинозных приступов, отека легких или снижения АД менее 90 мм рт.ст., может быть купирована синхронизированным с зубцом R электрическим разрядом на фоне кратковременного наркоза или в/в введения седативных препаратов. В ряде случаев эта форма ЖТ может быть устранена медикаментозно. Препарат выбора - амиодарон 300 мг (или 5 мг/кг) за 10-60 мин, в последующем при необходимости повторно по 150 мг каждые 10-15 мин или начать суточную инфузию препарата в дозе 900 мг (при необходимости на фоне инфузии возможны дополнительные введения препарата по 150 мг). Общая доза за сутки не должна превышать 2,2 г. На любом этапе введение амиодарона должно быть прекращено при увеличении продолжительности интервала QТ более 500 мс. Возможно использование прокаинамида в/в в дозе 12-17 мг/кг в виде 3-4 болюсов с интервалом 5 мин, скорость поддерживающей в/в инфузии 2-6 мг/мин до общей дозы 1000-2000 мг. 
Пароксизмы ЖТ типа «пируэт» в сочетании с удлинением интервала QT - показание к в/в введению сульфата магния (1-2 г в течение 5-10 мин под контролем уровня АД, при сохранении аритмии - повторные введения, при необходимости до суммарной суточной дозы 16 г).

В случаях когда ФЖ или ЖТ с остановкой кровообращения возникли при свидетелях, а дефибриллятор сразу недоступен, возможно нанесение прекордиального удара. При наличии дефибриллятора необходимо как можно быстрее нанести один несинхронизированный электрический разряд монофазной фрормы 360 Дж или двуфазной фооры 150-360 Дж (необходимая энергия зависит от модели аппарата; при отсутствии информации следует использовать разряд максимальной энергии). Если после развития ФЖ прошло несколько минут или давность ее возникновения не известна, необходимо начать сердечно-легочную реанимацию и продолжать ее до попыток дефибрилляции, как минимум, 2 мин. После каждой попытки дефибрилляции следует осуществлять, как минимум, 5 циклов закрытого массажа сердца до оценки ее эфффективности и необходимости нанесения повторного электрического разряда. Если аритмия сохраняется, то перед 3-м разрядом рекомендуется в/в болюсно ввести адреналин в дозе 1 мг (при необходимости повторно каждые 3-5 мин), перед 4-м разрядом - амиодарон в дозе 300 мг (при необходимости повторно еще 150 мг), а при недоступности амиодарона — лидокаин в дозе 1-1,5 мг/кг (при необходимости повторно 0,5-0,75 мг/кг каждые 5-10 мин до максимальной дозы 3 мг/кг). При низкоамплитудной ФЖ вероятность успешной дефибрилляции очень мала; в этих случаях целесообразно продолжать сердечнолегочную реанимацию в сочетании с введением адреналина.

Синусовая брадикардия, приводящая к существенным нарушениям гемодинамики, паузы более 3 с или синусовая брадикардия с ЧСС менее 40 уд/ мин в сочетании с артериальной гипотонией или недостаточностью кровообращения - показание к в/в введению атропина (по 0,5-1,0 мг каждые 5 мин; общая доза не должна превышать 0,04 мг/ кг). При сохранении гемодинамически значимой брадикардии следует начать временную чрескожную или эндокардиальную электростимуляцию (ЭС) (предпочтительно предсердную) [25].

Основные задачи при лечении отека легких улучшение оксигенации крови и снижение давления в капиллярах легких. Первая из них решается с помощью ингаляции кислорода (обычно через носовые катетеры) с объемной скоростью 4-8 л/мин с тем, чтобы сатурация артериальной крови была не менее 90\%. Если дыхание кислородом не обеспечивает достаточной сатурации артериальной крови (контроль за газовым составом крови!), может быть использовано дыхание через маску в режимах СРАР или ВіРАР. В наиболее тяжелых случаях прибегают к интубации трахеи и искусственной вентиляции легких (ИВЛ). Если она проводится с положительным давлением на выдохе, то ограничивается приток крови к сердцу, что служит дополнительным фактором коррекции давления в капиллярах легких. Наконец, метод ИВЛ позволяет значительно уменьшить энергозатраты больного, связанные с усиленными дыхательными движениями. При необходимости выполнения традиционных режимов ИВЛ целесообразно использовать дыхательный объем, не превышающий 6-10 мл/кг при частоте дыханий в пределах 12-22 в мин.

Больной, как правило, принимает сидячее положение. При этом уменьшается приток крови к сердцу. Следует уделить особое внимание тому, чтобы у больного с отеком легких были полностью исключены любые фиизиеские и, насколько это возможно, эмоциональные нагрузки.

Медикаментозная терапия первой линии препараты, уменьшающие приток крови к сердцу: органические нитраты, морфин, диуретики. Органические нитраты (в частности, нитроглицерин) эффрективные венодилататоры. В более высоких дозах они приводит к расширению артериол и с успехом могут использоваться при нормальном и повышенном АД. Важное, особенно в условиях острой коронарной недостаточности, свойство нитратов их антиишемическое действие. Поскольку эффрект таблетированного нитроглицерина проявляется уже в ближайшие 1-3 мин, такое лечение может быть начато практически немедленно, пока налаживается его в/в инфузия или если отек легких развивается в условиях, в которых парентеральное введение невозможно. Начальная скорость в/в инфузии нитроглицерина - 10 мкг/мин; она может увеличиваться на 5-10 мкг/мин через каждые 5-10 мин. Критерий для подбора оптимальной скорости введения нитроглицерина - уровень систолического АД (САД), которое не должно снижаться более чем на 10-15\% у нормотоников, на 20-25\% у лиц с артериальной гипертензией и не должно быть менее 90-95 мм рт.ст. Важное положительное свойство нитроглицерина - его короткий период полувыведения, что значительно облегчает подбор индивидуальной скорости инфузии. Основное противопоказание для нитратов - исходно низкий уровень АД (САД < 90 мм рт.ст.).

Морфин не только уменьшает приток крови к сердцу вследствие вазодилатации, но и обладает мощным обезболивающим и седативным действием. Его следует вводить в/в в виде болюса, причем первоначальная доза препарата не должна превышать 4-5 мг. Это правило особенно важно соблюдать у пожилых людей, у которых побочное действие морфина (угнетение дыхательного центра, трудноконтролируемая артериальная гипотензия вследствие избыточной венодилатации и пр.) может проявляться уже на фоне небольших доз. При недостаточном эфрфекте и отсутствии побочного действия препарат можно вводить повторно дробными дозами по 2-4 мг до достижения лечебного эффекта или возникновения побочных проявлений, не позволяющих увеличить дозу.

Важный компонент терапии отека легких диуретики. Используют в/в болюсное введение фуросемида. Рекомендуемая первоначальная доза 40 мг. При развернутой картине альвеолярного отека 
легких, признаках задержки жидкости в организме, почечной недостаточности начальная доза может быть увеличена до 60-80 мг. При недостаточной эффективности начальной дозы фуросемида, при повторном введении она может быть увеличена в 2 раза и более. Опасность, связанная с применением больших доз, если реакция больного на препарат неизвестна, — гиповолемия вследствие избыточного диуреза с последующей артериальной гипотензией и нарушением ритма, спровоцированные изменением содержания электролитов, в первую очередь калия.

Определенное значение у этой группы больных имеют и средства, обладающие положительным инотропным действием (допамин, добутамин). Обычно препараты этой группы присоединяют к лечению отека легких, если терапия вазодилататорами, морфином, диуретиками, ингаляцией кислорода не дает стабильного результата, и клинические и гемодинамические признаки отека легких сохраняются через 60 мин и более от начала лечения. Добутамин обладает умеренно выраженным периферическим артериодилатирующим эффректом (в малых дозах 2-10 мкг/кг/мин), который при больших скоростях введения (до 20 мкг/кг/мин) может смениться вазоконстрикторным и умеренным позитивным инотропным действием. Допамин обладает сходными характеристиками, но в отличие от добутамина, обладает более выраженным вазоконстрикторным действием (при средних и высоких дозировках более 10 мкг/кг/мин). Важное свойство допамина - снижение сосудистого сопротивления в почках и других внутренних органах при малых скоростях инфузии (2-5 мкг/кг/мин). Допамин в малых дозах усиливает действие диуретиков, и эта комбинация применяется, если эффективность монотерапии мочегонными средствами недостаточна.

В некоторых случаях шока при неэффективности каждого из этих препаратов рекомендуется их совместное введение. Оптимальная дозировка допамина и добутамина подбирается индивидуально под контролем параметров центральной гемодинамики, причем желателен и контроль величины сердечного индекса. Доза симпатомиметиков должна быть снижена при развитии тахикардии, аритмии или усугублении ишемии миокарда [26].

С целью своевременного выявления жизнеугрожающих нарушений ритма сердца, обеспечения эффективного контроля за состоянием пострадавшего, оценки корректности проводимой терапии целесообразно проведение постоянного ЭКГ-мониторинга, контроля показателей гемодинамики (АД, ЧСС) и дыхания (частота дыхания, $\mathrm{SaCh}$ ) на протяжении всего догоспитального периода.

Прогноз при закрытых травмах сердца различный. Возможно полное выздоровление и восстановление трудоспособности или неполное выздоровление (в дальнейшем могут появляться боли, связанные с фризической нагрузкой, или аритмии). Смерть при закрытой травме сердца может наступить в том случае, если развивается фибрилляция желудочков, асистолия, сердечная недостаточность или разрыв миокарда.

\section{ЛИТЕРАТУРА}

1. Грифрфин, Б. Кардиология / Б. Гриффрин, Э. Тополь. М.: Практика, 2008. - 1248 с.

2. Гуманенко, Е.К. Диагностика ушиба сердца у пострадавших с сочетанными травмами груди / Е.К. Гуманенко, О.В. Кочергаев, С.В. Гаврилин [и др.] // Вестник хирургии им. И.И. Грекова. - 2000. - № 6. - С.36-40.

3. Диагностика и лечение больных острым инфарктом миокарда с подъемом сегмента ST электрокардиограммы: метод. рекомендации. - М., 2013. URL: http://www.acutecardio.ru/article/23/diagnostikai-lechenie-bolnyih-ostryim-infarktom (дата обращения: 13.05.2015).

4. Жиго, П.Т. Диагностика закрытой травмы сердца / П.Т. Жиго, Н.Д. Томнюк, А.Н. Черных [и др.] // Бюллетень ВСНЦ СО РАМН. — 2005. — № 3(41). — С.161.

5. Жиго, П.Т. Клинические и электрокардиографические проявления повреждения сердца у больных с закрытой травмой груди / П.Т. Жиго, Е.А. Селезов, Л.С. Поликарпов // Сибирский медицинский журнал. - 2004. № 3. - С.85-88.

6. Замятин, П.Н. Диагностические особенности посттравматической миокардиопатии и закрытой травмы сердца / П.Н. Замятин, Н.В. Баранова, Т.А. Куценко // Медицина неотложных состояний. - 2006. № 6(7). - C.71-73.

7. Корпачева, О.В. Механизмы формирования миокардиальной дисфункции и метаболическая цитопротекция при ушибах сердца (экспериментальное исследование): автореф. дис. ... д-ра мед. наук / Корпачева Ольга Валентиновна; Омская гос. мед. акад. - Омск, 2009. - 42 c.

8. Кочергаев, О.В. Распознавание ушиба сердца при сочетанной травме груди / О.В. Кочергаев // Хирургия. Журнал им. Н.И. Пирогова. - 2000. - № 9. C.25-29.

9. Лачаева, М.А. Диагностика и интенсивная терапия закрытой тупой травмы сердца на догоспитальном этапе: автореф. дис. ... канд. мед. наук / Лачаева Мария Александровна; Московская гос. мед. акад. - М., 2006. - 30 c.

10. Маныкин, И.Е. Оценка функционального состояния миокарда при закрытой травме сердца / И.Е. Маныгин // Медицина критических состояний. — 2005. — № 6. C. $16-20$.

11. Марчук, В.Г. Адаптированная классификация ушибов сердца при закрытой травме груди на фроне политравмы / В.Г. Марчук, А.И. Чепень, А.Я. Кузьмин [и др.] // Здоровье. Медицинская экология. Наука. — 2012. № $1 / 2$. - C.92.

12. Новоселов, В.П. Проблемы диагностики ушиба сердца у живых лиц при экспертизе закрытой тупой травмы грудной клетки / В.П. Новоселов, С.В. Савченко, М.В. Вороновская [и др.] // Сибирский медицинский журнал. — 2011. - Т. 26, № 1. - С.39-41.

13. Новоселов, В.П. Проблемы экспертной оценки тяжести вреда здоровью при ушибах сердца в случае экспертизы живых лиц / В.П. Новоселов, С.В. Савченко, М.В. Вороновская [и др.] // Сибирский медицинский журнал. - 2008. — № 1. - С.65-67.

14. Новоселов, В.П. Ультраструктурные изменения миофиибрилл кардиомиоцитов как диагностический признак ушиба сердца / В.П. Новоселов, С.В. Савченко, Д.А. Кошляк [и др.] // Актуальные вопросы судебной медицины и экспертной практики. - 2008. — № 14. C. $47-49$.

15. Орджоникидзе, З.Г. Сотрясение сердца (commotiocordis) как причина внезапной сердечной смерти в спорте / З.Г. Орджоникидзе, В.И. Павлов, А.Е. Дружинин 
[и др.] // Медицина неотложных состояний. - 2008. № 1(14). - С.91-96.

16. Патоморфология миокарда при ушибах сердца / В.П. Новоселов, С.В. Савченко, Е.А. Романова, В.Г. Цимерман. - Новосибирск: Наука, 2002. - 168 с.

17. Пименов, Л.Т. Диагностика и фракторы риска ушиба сердца при закрытой травме грудной клетки / Л.Т. Пименов, Д.Н. Коротаева // Врач скорой помощи. 2012. - № 9. - С.24-28.

18. Пименов, Л.Т. Клинико-функциональное состояние сердечно-сосудистой системы при закрытой травме грудной клетки / Л.Т. Пименов, Д.В. Коротаева, Н.Н. Соловьева [и др.]// Практическая медицина. — 2011. № 4. - С.90-92.

19. Стажадзе, Л.Л. Анализ обезболивания, проводимого на догоспитальном этапе пострадавшим с травматическими повреждениями / Л.Л. Стажадзе, И.С. Элькис, Е.А. Спиридонова [и др.] // Анестезиология и реаниматология. - 2001. — № 4. - С.71-73.

20. Стажадзе, Л.Л. Вопросы классификации, патогенеза, клиники и диагностики ушиба сердца / Л.Л. Стажадзе, Е.А. Спиридонова, М.А. Лачаева // Медицина критических состояний. - 2000. - № 2. - С.4-8.

21. Стажадзе, Л.Л. Ушиб сердца (этиология, клиника, терапия на госпитальном этапе) / Л.Л. Стажадзе, Е.А. Спиридонова, М.А. Лачаева // ЦЭМПИНФОРМ. 2003. - № 4. - C.6-10.

22. Стажадзе, Л.Л. ЭКГ-диагностика ушиба сердца на догоспитальном этапе / Л.Л. Стажадзе, Е.А. Спиридонова, М.А. Лачаева // Здоровье столицы-2004: тез. докл. Третьей московской ассамблеи, 16-17 дек. 2004 г. М., 2004. - С.67-68.

23. Травмы грудной клетки / И.Ф. Ахтямов, Н.Б. Амиров, М.В. Потапова [и др.]. — Казань: МСЧ МВД РТ, 2012. $40 \mathrm{C}$.

24. Туманов, Э.В. Теории повреждения сердца при тупой травме грудной клетки / Э.В. Туманов, 3.Ю. Соколова // Судебная медицинская экспертиза. - 2010. — № 6. C.44-48.

25. Федеральные клинические рекомендации по диагностике и лечению нарушений ритма и проводимости сердца. - М., 2013. — URL: http://www.acutecardio. ru/article/21/federalnyie-klinicheskie-rekomendatsii-podiagnost (дата обращения: 13.05.2015).

26. Федеральные клинические рекомендации по диагностике и лечению хронической и острой сердечной недостаточности: метод. рекомендации. - М., 2013. URL: http://www.acutecardio.ru/article/18/federalnyieklinicheskie-rekomendatsii-po-diagnost (дата обращения: 13.05.2015).

27. Чепень, А.И. Клинико-электрокардиографическая характеристика сотрясений сердца / А.И. Чепень, В.Г. Марчук, В.В. Чиж // Здоровье. Медицинская экология. Наука. - 2012. - № $1 / 2$ - С.54.

28. Шепеленко, А.Ф. Диагностика и лечение сочетанной патологии легких и сердца при травме в условиях терапевтического стационара / А.Ф. Шепеленко, Н.Д. Шепеленко, М.М. Кириллов // Пульмонология. 2004. - № 4. - С.81-86.

29. Шепеленко, А.Ф. Патология внутренних органов при травме в терапевтической клинике / А.Ф. Шепеленко, М.М. Кириллов, Н.Д. Шепеленко. - М.: МИА, 2007. $333 \mathrm{c}$.

\section{REFERENCES}

1. Griffin, B. Kardiologiya [Cardiology] / B. Griffin, E. Topol'. M.: Praktika, 2008. - $1248 \mathrm{~s}$

2. Gumanenko, E.K. Diagnostika ushiba serdca u postradavshih s sochetannymi travmami grudi [Diagnosis of a bruise of heart in victims of the combined injuries of thorax] / E.K. Gumanenko, O.V. Kochergaev, S.V. Gavrilin [i dr.] // Vestnik hirurgii im. I.I. Grekova [The messenger of surgery of I.I. Grekov]. — 2000. - № 6. - S.36-40.

3. Diagnostika i lechenie bol'nyh ostrym infarktom miokarda s pod'emom segmenta ST elektrokardiogrammy: metod. rekomendacii [Diagnostics and treatment of patients with acute myocardial infarction with elevation of the ST segment of the electrocardiogram. Methodical recommendations]. - M., 2013. - URL: http://www. acutecardio.ru/article/23/diagnostika-i-lechenie-bolnyihostryim-infarktom (data obrascheniya: 13.05.2015).

4. Zhigo, P.T. Diagnostika zakrytoi travmy serdca [Diagnosis of the closed heart injury] / P.T. Zhigo, N.D. Tomnyuk, A.N. Chernyh [i dr.] // Byulleten' VSNC SO RAMN [The bulletin VSNTs of the Russian Academy of Medical Science]. - 2005. - № 3(41). - S.161.

5. Zhigo, P.T. Klinicheskie i elektrokardiograficheskie proyavleniya povrezhdeniya serdca u bol'nyh s zakrytoi travmoi grudi [Clinical and electrocardiographic manifestations of injury of heart at patients with the closed thorax injury] / P.T. Zhigo, E.A. Selezov, L.S. Polikarpov // Sibirskii medicinskii zhurnal [Siberian medical journal]. 2004. - № 3. - S.85-88.

6. Zamyatin, P.N. Diagnosticheskie osobennosti posttravmaticheskoi miokardiopatii i zakrytoi travmy serdca serdca [Diagnostic features of a post-traumatic myocardiopathy and the closed heart injury]/P.N. Zamyatin, N.V. Baranova, T.A. Kucenko // Medicina neotlozhnyh sostoyanii [Medicine of medical emergencies]. — 2006. № 6(7). - S.71-73.

7. Korpacheva, O.V. Mehanizmy formirovaniya miokardial'noi disfunkcii i metabolicheskaya citoprotekciya pri ushibah serdca (eksperimental'noe issledovanie) [Mechanisms of formation of myocardial dysfunction and metabolic cytoprotection at bruises of heart (pilot study)]: avtoref. dis. ... d-ra med. nauk / Korpacheva Ol'ga Valentinovna; Omskaya gos. med. akad. - Omsk, 2009. - $42 \mathrm{~s}$.

8. Kochergaev, O.V. Raspoznavanie ushiba serdca pri sochetannoi travme grudi [Recognition of a bruise of heart at the combined injury of thorax] / O.V. Kochergaev // Hirurgiya. Zhurnal im. N.I. Pirogova [Surgery. The journal of N.I. Pirogov]. — 2000. — № 9. - S.25-29.

9. Lachaeva, M.A. Diagnostika i intensivnaya terapiya zakrytoi tupoi travmy serdca na dogospital'nom etape [Diagnostics and intensive therapy of the closed blunt injury of heart at a pre-hospital stage]: avtoref. dis. ... kand. med. nauk / Lachaeva Mariya Aleksandrovna; Moskovskaya gos. med. akad. - M., 2006. - 30 s.

10. Manykin, I.E. Ocenka funkcional'nogo sostoyaniya miokarda pri zakrytoi travme serdca [Assessment of a functional condition of a myocardium at the closed heart injury] / I.E. Manygin // Medicina kriticheskih sostoyanii [Medicine of critical conditions]. - 2005. - № 6. S.16-20.

11. Marchuk, V.G. Adaptirovannaya klassifikaciya ushibov serdca pri zakrytoi travme grudi na fone politravmy [The adapted classification of bruises of heart at the closed thorax injury at poly-trauma] / V.G. Marchuk, A.I. Chepen', A.Ya. Kuz'min [i dr.] // Zdorov'e. Medicinskaya ekologiya. Nauka [Health. Medical ecology. Science]. — 2012. № $1 / 2$. - S.92.

12. Novoselov, V.P. Problemy diagnostiki ushiba serdca u zhivyh lic pri ekspertize zakrytoi tupoi travmy grudnoi kletki [Problems of diagnosis of a bruise of heart at living persons at examination of the closed blunt injury of a thorax] / V.P. Novoselov, S.V. Savchenko, M.V. Voronovskaya [i dr.] // Sibirskii medicinskii zhurnal [Siberian medical journal]. 2011. - T. 26, № 1. - S.39-41.

13. Novoselov, V.P. Problemy ekspertnoi ocenki tyazhesti vreda zdorov'yu pri ushibah serdca v sluchae ekspertizy zhivyh 
lic [Problems of an expert assessment of harm to health at heart bruises in case of examination of living persons] / V.P. Novoselov, S.V. Savchenko, M.V. Voronovskaya [i dr.] // Sibirskii medicinskii zhurnal [Siberian medical journal]. 2008. — № 1. - S.65-67.

14. Novoselov, V.P. Ul'trastrukturnye izmeneniya miofibrill kardiomiocitov kak diagnosticheskii priznak ushiba serdca [Ultrastructural changes of myofibrils as diagnostic symptom of a bruise of heart] / V.P. Novoselov, S.V. Savchenko, D.A. Koshlyak [i dr.] // Aktual'nye voprosy sudebnoi mediciny i ekspertnoi praktiki [Topical issues of forensic medicine and expert practice]. — 2008. — № 14. S.47-49.

15. Ordzhonikidze, Z.G. Sotryasenie serdca (commotiocordis) kak prichina vnezapnoi serdechnoi smerti v sporte [Concussion of heart (commotion cordis) as the reason of sudden cardiac death in sport] / Z.G. Ordzhonikidze, V.I. Pavlov, A.E. Druzhinin [i dr.] // Medicina neotlozhnyh sostoyanii [Medicine of medical emergencies]. — 2008. № 1(14). - S.91-96.

16. Patomorfologiya miokarda pri ushibah serdca [Pathomorphology of a myocardium at heart bruises] / V.P. Novoselov, S.V. Savchenko, E.A. Romanova, V.G. Cimerman. - Novosibirsk: Nauka, 2002. - $168 \mathrm{~s}$.

17. Pimenov, L.T. Diagnostika i faktory riska ushiba serdca pri zakrytoi travme grudnoi kletki [Diagnostics and risk factors of a bruise of heart at the closed thorax trauma] / L.T. Pimenov, D.N. Korotaeva // Vrach skoroi pomoschi [Emergency doctor]. - 2012. - № 9. - S.24-28.

18. Pimenov, L.T. Kliniko-funkcional'noe sostoyanie serdechnososudistoi sistemy pri zakrytoi travme grudnoi kletki [Clinical and functional condition of cardiovascular system at the closed thorax injury] / L.T. Pimenov, D.V. Korotaeva, N.N. Solov'eva [i dr.]// Prakticheskaya medicina [Practical medicine]. — 2011. — № 4. - S.90-92.

19. Stazhadze, L.L. Analiz obezbolivaniya, provodimogo na dogospital'nom etape postradavshim s travmaticheskimi povrezhdeniyami [The analysis of the anesthesia which is carried out at a pre-hospital stage in victim with traumatic damages] / L.L. Stazhadze, I.S. El'kis, E.A. Spiridonova [i dr.] // Anesteziologiya i reanimatologiya [Anesthesiology and resuscitation]. — 2001. — № 4. - S.71-73.

20. Stazhadze, L.L. Voprosy klassifikacii, patogeneza, kliniki i diagnostiki ushiba serdca [Questions of classification, pathogenesis, clinic and diagnosis of a bruise of heart] / L.L. Stazhadze, E.A. Spiridonova, M.A. Lachaeva // Medicina kriticheskih sostoyanii [Medicine of critical conditions]. - 2000. - № 2. - S.4-8.

21. Stazhadze, L.L. Ushib serdca (etiologiya, klinika, terapiya na gospital'nom etape) [Heart bruise (an etiology, clinic, therapy at a hospital stage)] / L.L. Stazhadze, E.A. Spiridonova, M.A. Lachaeva // CEMPINFORM. 2003. - № 4. - S.6-10.

22. Stazhadze, L.L. EKG-diagnostika ushiba serdca na dogospital'nom etape [Electrocardiogram diagnosis of a bruise of heart at a pre-hospital stage] / L.L. Stazhadze, E.A. Spiridonova, M.A. Lachaeva // Zdorov'e stolicy-2004: tez. dokl. Tret'ei moskovskoi assamblei [Health of the capital2004: Theses of reports of the Third Moscow assembly], 16-17 dek. 2004 g. - M., 2004. - S.67-68.

23. Travmy grudnoi kletki [Thorax injuries] / I.F. Ahtyamov, N.B. Amirov, M.V. Potapova [i dr.]. - Kazan': MSCH MVD RT, 2012. - 40 s.

24. Tumanov, E.V. Teorii povrezhdeniya serdca pri tupoi travme grudnoi kletki [Theories of injury of heart at blunt injury of a thorax] / E.V. Tumanov, Z.Yu. Sokolova // Cudebnaya medicinskaya ekspertiza [Judicial medical examination]. - 2010. - № 6. - S.44-48.

25. Federal'nye klinicheskie rekomendacii po diagnostike i lecheniyu narushenii ritma i provodimosti serdca [Federal clinical recommendations on diagnostics and treatment of disorders of rhythm and conductivity of heart]. - M., 2013. - URL: http://www.acutecardio.ru/article/21/ federalnyie-klinicheskie-rekomendatsii-po-diagnost (data obrascheniya: 13.05.2015).

26. Federal'nye klinicheskie rekomendacii po diagnostike i lecheniyu hronicheskoi i ostroi serdechnoi nedostatochnosti: metod. rekomendacii [Federal clinical recommendations on diagnostics and treatment of chronic and acute heart failure. Methodical recommendations]. - M., 2013. - URL: http://www.acutecardio.ru/article/18/ federalnyie-klinicheskie-rekomendatsii-po-diagnost (data obrascheniya: 13.05.2015)

27. Chepen', A.I. Kliniko-elektrokardiograficheskaya harakteristika sotryasenii serdca [Clinical and electrocardiographic characteristic of concussions of heart] / A.I. Chepen', V.G. Marchuk, V.V. Chizh // Zdorov'e. Medicinskaya ekologiya. Nauka [Health. Medical ecology. Science]. - 2012. — № 1/2 - S.54.

28. Shepelenko, A.F. Diagnostika i lechenie sochetannoi patologii legkih i serdca pri travme $v$ usloviyah terapevticheskogo stacionara [Diagnostics and treatment of the combined pathology of lungs and heart at a trauma in the conditions of a therapeutic hospital] / A.F. Shepelenko, N.D. Shepelenko, M.M. Kirillov // Pul'monologiya [Pulmonology]. — 2004. — № 4. - S.81-86.

29. Shepelenko, A.F. Patologiya vnutrennih organov pri travme $v$ terapevticheskoi klinike [Pathology of internal organs at a trauma in therapeutic clinic] / A.F. Shepelenko, M.M. Kirillov, N.D. Shepelenko. - M.: MIA, 2007. - 333 s.

() А.З. Шарафеев, В.А. Баязитова, А.Р. Исхакова, 2015

УДК 616.127-005.8-08(048.8)

\section{КАРДИОПРОТЕКТИВНЫЙ ЭФФЕКТ ИШЕМИЧЕСКОГО КОНДИЦИОНИРОВАНИЯ}

АЙДАР ЗАЙТУНОВИЧ ШАРАФЕЕВ, докт. мед. наук, зав. кафедрой кардиологии, рентгеноэндоваскулярной и сердечно-сосудистой хирургии ГБОУ ДПО «Казанская государственная медицинская академия» Минздрава России, зав. отделением ангиографических и рентгенооперационных исследований ГАУЗ РКБ № 2, Казань, Россия, e-mail: aidarch@mail.ru

ВИЛЯ АЙРАТОВНА БАЯЗИТОВА, аспирант кафедры кардиологии, рентгеноэндоваскулярной и сердечно-сосудистой хирургии ГБОУ ДПО «Казанская государственная медицинская академия» Минздрава России, Казань, Россия, тел. 8-953-490-15-03, e-mail: vilionora@yandex.ru

АЛИЯ РУСТЕМОВНА ИСХАКОВА, врач функциональной диагностики диагностического отделения ГАУЗ РКПБ им. акад. В.М. Бехтерева, Казань, Россия, e-mail: al-rust@mail.ru

Реферат. Цель исследования - анализ последних публикаций по проблеме кардиопротекции при остром инфаркте миокарда (ОИМ). Материал и методы. Проведен обзор публикаций последних лет, посвященных различным методам кардиопротекции, которые уменьшают зону некроза миокарда по сравнению с плацебо. 
Результаты и их обсуждение. Несмотря на прогресс в лечении ОИМ, смертность от этого заболевания продолжает оставаться на первом месте. Существующая стандартная терапия не снижает зону некроза миокарда. В статье рассмотрены актуальные вопросы кардиопротекции - механические и физические методы с учетом последних клинических исследований. Освещены основные аспекты ишемического кондиционирования, дистанционного ишемического кондиционирования, терапевтической гипотермии и гипероксигенационной терапии. Проанализированы два последних крупных рандомизированных исследования RAPID-MI-ICE и AMIHOT II, опубликованные в 2010 и 2009 гг. соответственно. Заключение. Ишемическое кондиционирование доказало свои кардиопротективные свойства в нескольких клинических исследованиях.

Ключевые слова: острый инфаркт миокарда, кардиопротекция, ишемическое кондиционирование.

\title{
CARDIOPROTECTIVE EFFECT OF ISCHEMIC CONDITIONING
}

\author{
AYDAR Z. SHARAFEEV, Doctor of Medical Science, Head of the Department of cardiology, endovascular \\ and cardiovascular surgery of SBEI APE «Kazan State Medical Academy» of Russian Ministry of Health, Head of cath-lab \\ of SAIH RCH № 2, Kazan, Russia, e-mail: aidarch@mail.ru \\ VILAY A. BAYAZITOVA, graduate student of the Department of cardiology, endovascular and cardiovascular surgery \\ of SBEI APE «Kazan State Medical Academy» of Russian Ministry of Health, Kazan, Russia, tel. 8-905-349-15-03, \\ e-mail: vilionora@yandex.ru \\ ALIYA R. ISKHAKOVA, functional diagnostic's doctor of diagnostic department of SAIH RCPH \\ of name after acad. V.M. Bekhterev, Kazan, Russia, e-mail: al-rust@mail.ru
}

\begin{abstract}
Aim. To analyze the recent publications on the problem of cardioprotection in acute myocardial infarction (AMI). Material and methods. A review the recent publications on the various methods of cardioprotection which reduce the infarct size compared to placebo. Results and discussion. Despite the progress in the treatment of acute myocardial infarction, mortality from this disease persists the leading place. The current standard therapy does not reduce the size of myocardial necrosis. In this article we review current issues of cardioprotection: mechanical and physical methods based on the recent clinical trials. Throw light upon main aspects of ischemic conditioning, mild hypothermia and supersaturated oxygen therapy. Analyzed last two recent large randomized trials RAPID-MI-ICE and AMIHOT II published in 2010 and 2009, respectively. Conclusions. Ischemic conditioning proved its cardioprotective properties in several clinical trials.
\end{abstract}

Key words: acute myocardial infarction, cardioprotection, ischemic conditioning.

$\mathrm{O}$ стрый инфаркт миокарда (ОИМ) остается главной причиной смерти в Соединенных Штатах. Около 1 млн ОИМ происходит ежегодно, из них примерно 29\% - инфаркт миокарда с подъемом сегмента ST [1]. Понимание патогенеза окклюзии коронарной артерии и некроза миокарда создало предпосылки для снижения показателей заболеваемости и смертности из-за ОИМ. До 1986 г. [2] восстановление кровотока в закупоренной коронарной артерии с помощью внутривенной тромболитической терапии было стандартом медицинской помощи как для уменьшения последующей сердечной недостаточности, так и для снижения летальности [3, 4]. Теория спасения миокарда, который мог быть обречен на ишемическую смерть, путем восстановления кровотока оказалась жизнеспособной, и лучшие методы открытия окклюзированной коронарной артерии стали быстро развиваться. Чрескожная транслюминальная коронарная ангиопластика [5-7] и стентирование коронарных артерий [8] широко изучались с 1990-х по 2000 г., они являются более предпочтительной стратегией лечения, чем тромболитики [9].

Несколько методов кардиопротекции показали способность ограничивать зону инфаркта миокарда в клинических исследованиях, например, интервенционные техники, которые доказали свою эффективность: ишемическое посткондиционирование и дистанционное ишемическое прекондиционирование; обе могут уменьшить зону инфаркта. Снижение температуры тела с помощью инфузии холодного физиологического раствора и охлаждения катетеров также показали эффрективность в определенных случаях.
Прекондиционирование. Активация эндогенных защитных механизмов организма через повторение нелетальных приступов ишемии-реперфузии перед пролонгированным эпизодом ишемии - это мощный способ ограничить зону инфаркта. Этот метод, известный как ишемическое прекондиционирование, был описан Murry 25 лет назад [11] и продолжает быть золотым стандартом, против которого все экспериментальные кардиопротективные методы проигрывают. По определению, ишемическое прекондиционирование должно быть применено перед ишемическим событием, затрудняя его использование в условиях ОИМ. Это, однако, эффективно в сердечно-сосудистой хирургии [12] и плановом чрескожном коронарном вмешательстве (ЧКВ) (ситуациях, когда ишемия миокарда запланирована) [13].

Возможно, даже более ценно, что изучение прекондиционирования привело к глубокому пониманию механизмов ишемии-реперфузионного синдрома, открыв тем самым двери для фармакологических средств, которые могут имитировать эфффект ишемического прекондиционирования. Физиологические, клеточные и молекулярные механизмы ишемического прекондиционирования изучались в течение многих лет, и их подробное обсуждение выходит за рамки этого обзора. Говоря кратко, короткие эпизоды ишемии-реперфузии привлекают рецепторы клеточной поверхности к различным медиаторам (например, аденозин, брадикинин, опиоды), которые высвобождаются во время ишемии. Эти рецепторы инициируют комплекс сигнального каскада, включающий в себя множество защитных киназ, в том числе группу киназ реперфузионного повреждения, активные формы кислорода и митохондриальные 
компоненты. Конечным результатом является кардиопротективное состояние, которое опосредовано несколькими эффекторными молекулами, такими как проницаемая переходная пора митохондрий (ПППМ) [14] и др.

Кроме того, другие методы ишемического кондиционирования, которые являются клинически более применимыми, были разработаны и доказали свою эффективность в уменьшении зоны инфаркта как на животных, так и в клинических исследованиях.

Посткондиционирование и циклоспорин. Хотя ишемическое прекондиционирование доказало свои кардиопротективные свойства, его клиническое применение, очевидно, ограничено. В надежде сделать ишемическое кондиционирование клинически применимым, Zhao [15] использовал принципы ишемического прекондиционирования, но после произошедшего ишемического события (точно имитируя ОИМ) на собаках во время реперфузионной терапии на фоне ишемии. Действительно, эти короткие эпизоды окклюзии коронарной артерии применяются немедленно после ишемического инсульта, ограничивающего зону ИМ таким же образом, как и ишемическое прекондиционирование.

Хотя не все моделированные на животных исследования показывают превосходство посткондиционирования на размер инфаркта, имеются убедительные данные у людей. В течение первых двух лет исследований на животных, проводимом Zhao [15], ишемическое посткондиционирование уже изучалось клинически (таблица).
В 2005 г. Staat и соавт. [16] опубликовали результаты важного исследования о посткондиционировании. Это было многоцентровое рандомизированное контролируемое исследование 30 пациентов с ОИМ с подъемом сегмента ST и вовлечением левой передней или правой коронарной артерии, которым проводилось ЧКВ. Протокол посткондиционирования состоял из 4 циклов: 1 мин инфляции баллона следовала за 1 мин дефляции баллона, в течение 1 мин восстанавливался кровоток после имплантации коронарного стента. У пациентов в группе посткондиционирования было обнаружено снижение на 36\% зоны инфаркта по определению в сыворотке крови креатинфосфокиназы (КФК) в течение первых 72 ч от реперфузии и более низкие уровни КФК во время пика. Степень кровоснабжения также была значительно выше в группе посткондиционирования, чем в контрольной, вероятно, за счет улучшенной перфузии миокарда в первые минуты реперфузии.

В 2008 г. Laskey и соавт. [17] использовали протокол из 2 циклов 90-секундного раздувания баллона, следующего за 3-минутной реперфузией у пациентов с 6-часовым передним трансмуральным ОИМ. Они обнаружили, что пациенты с посткондиционированием имели значительно более низкие уровни пика КФК и более быстрое опущение сегмента ST на изолинию, а также улучшение скоростных параметров дистального коронарного кровотока.

Несмотря на тонкие различия в протоколах посткондиционирования, включая измерение зон риска, Staat и соавт. [16, 17], Laskey и Staat про-

Клинические исследования, изучающие посткондиционирование при ОИМ с ПСТ

\begin{tabular}{|c|c|c|c|c|}
\hline Автор, год & $\begin{array}{c}\text { Дизайн } \\
\text { исследования }\end{array}$ & $\begin{array}{c}\text { Протокол } \\
\text { посткондиционирова- } \\
\text { ния }\end{array}$ & Первичные конечные точки & Результат \\
\hline $\begin{array}{l}\text { Staat, } \\
2005[16]\end{array}$ & $\begin{array}{l}\text { Проспективное от- } \\
\text { крытое мультицент- } \\
\text { ровое рандомизиро- } \\
\text { ванное контролируе- } \\
\text { мое исследование } \\
(n=30)\end{array}$ & $\begin{array}{l}4 \text { цикла: окклюзия } \\
\text { в течение } 1 \text { мин / } \\
\text { 1-минутная реперфузия } \\
\text { с 1-минутным индексом } \\
\text { реперфузии }\end{array}$ & $\begin{array}{l}\text { Высвобождение КФК в сыво- } \\
\text { ротоку крови в течение } 72 \text { ч от } \\
\text { реперфузии. } \\
\text { Пик уровня КФК. } \\
\text { Степень кровоснабжения во вре- } \\
\text { мя восстановления кровотока. } \\
\text { Изменение ST-сегмента в тече- } \\
\text { ние } 48 \text { ч }\end{array}$ & $\begin{array}{l}\text { На } 36 \% \text { уменьшение } \\
\text { площади по данным } \\
\text { кривой высвобождения } \\
\text { КФК. } \\
\text { Повышение степени } \\
\text { кровоснабжения }\end{array}$ \\
\hline $\begin{array}{l}\text { Laskey, } \\
2005[46]\end{array}$ & $\begin{array}{l}\text { Проспективное от- } \\
\text { крытое одноцентро- } \\
\text { вое рандомизирован- } \\
\text { ное контролируемое } \\
\text { исследование }(n=17)\end{array}$ & $\begin{array}{l}2 \text { цикла: } 90 \text { с окклюзии / } \\
3 \text {-5 мин реперфузии }\end{array}$ & $\begin{array}{l}\text { Скоростные параметры дисталь- } \\
\text { ного коронарного кровотока, из- } \\
\text { меренного с помощью допплера. } \\
\text { Изменение ST-сегмента }\end{array}$ & $\begin{array}{l}\text { Снижение величины } \\
\text { конечной высоты ST- } \\
\text { сегмента. } \\
\text { Увеличение скорости } \\
\text { возврата сегмента ST на } \\
\text { изолинию. } \\
\text { Улучшенный резерв } \\
\text { скорости коронарного } \\
\text { кровотока }\end{array}$ \\
\hline $\begin{array}{l}\text { Laskey, } \\
2008[13]\end{array}$ & $\begin{array}{l}\text { Проспективное от- } \\
\text { крытое одноцентро- } \\
\text { вое рандомизирован- } \\
\text { ное контролируемое } \\
\text { исследование (24 па- } \\
\text { циента с передним } \\
\text { ОИМ с ПСТ) } \\
\end{array}$ & $\begin{array}{l}2 \text { цикла: } 90 \text { с окклюзии / } \\
3 \text { мин реперфузии }\end{array}$ & $\begin{array}{l}\text { Скоростные параметры дисталь- } \\
\text { ного коронарного кровотока, } \\
\text { измеренного с помощью доп- } \\
\text { плера. } \\
\text { Изменение ST-сегмента. } \\
\text { Пик высвобождения КФК }\end{array}$ & $\begin{array}{l}\text { Значительное и более } \\
\text { быстрое опущение сег- } \\
\text { мента ST на изолинию. } \\
\text { Улучшенный резерв } \\
\text { скорости коронарного } \\
\text { кровотока. } \\
\text { Низкие уровни пика КФК }\end{array}$ \\
\hline $\begin{array}{l}\mathrm{Ma}, \\
2006[47]\end{array}$ & $\begin{array}{l}\text { Проспективное от- } \\
\text { крытое одноцентро- } \\
\text { вое рандомизирован- } \\
\text { ное контролируемое } \\
\text { исследование (94 па- } \\
\text { циента с первичным } \\
\text { ОИМ с ПСТ) }\end{array}$ & $\begin{array}{l}3 \text { цикла: } 30 \text { с окклюзии } \\
\text { / } 30 \text { с реперфузии с } \\
\text { 1-минутным индексом } \\
\text { реперфузии }\end{array}$ & $\begin{array}{l}\text { Высвобождение КФК/МБ-КФК } \\
\text { в сыворотоку крови в течение } \\
\text { первых } 72 \text { ч. } \\
\text { Сократительная функция миокар- } \\
\text { да через } 8 \text { нед после инфаркта. } \\
\text { Уровень оксидативного теста } \\
\text { (МДА) }\end{array}$ & $\begin{array}{l}\text { Низкий уровень пика } \\
\text { КФК-МБ. } \\
\text { Быстрое СТFC. } \\
\text { Значительные измене- } \\
\text { ния в WMSI. } \\
\text { Низкий уровень МДА- } \\
\text { продуктов }\end{array}$ \\
\hline
\end{tabular}


Окончание табл.

\begin{tabular}{|c|c|c|c|c|}
\hline Автор, год & $\begin{array}{c}\text { Дизайн } \\
\text { исследования }\end{array}$ & $\begin{array}{c}\text { Протокол } \\
\text { посткондиционирова- } \\
\text { ния }\end{array}$ & Первичные конечные точки & Результат \\
\hline $\begin{array}{l}\text { Thibault, } \\
2008 \text { [48] }\end{array}$ & $\begin{array}{l}\text { Проспективное от- } \\
\text { крытое одноцентро- } \\
\text { вое рандомизирован- } \\
\text { ное контролируемое } \\
\text { исследование (38 па- } \\
\text { циентов с первичным } \\
\text { ОИМ с ПСТ) }\end{array}$ & $\begin{array}{l}4 \text { цикла: 1-минутная } \\
\text { окклюзии / } 1 \text { мин репер- } \\
\text { фузии с 1-минутным } \\
\text { индексом реперфузии }\end{array}$ & $\begin{array}{l}\text { Размер инфаркта (с помощью } \\
\text { КФК и тропонинов). } \\
\text { Индекс покоя- } \\
\text { перераспределения ПЭТ через } \\
6 \text { мес. } \\
\text { ЭхоКГ через } 1 \text { год }\end{array}$ & $\begin{array}{l}\text { Уменьшение на } \\
\text { 39\% индекса покоя- } \\
\text { распределения ПЭТ. } \\
\text { На 40\% уменьшение } \\
\text { зоны инфаркта. } \\
\text { Улучшение ФВ через } \\
1 \text { год. } \\
\text { Улучшение WMSI через } \\
1 \text { год }\end{array}$ \\
\hline $\begin{array}{l}\text { Lonborg, } \\
2010[49]\end{array}$ & $\begin{array}{l}\text { Проспективное от- } \\
\text { крытое одноцентро- } \\
\text { вое рандомизиро- } \\
\text { ванное контролируе- } \\
\text { мое исследование } \\
(n=118)\end{array}$ & $\begin{array}{l}4 \text { цикла: } 30 \text { с окклюзии } \\
\text { / } 30 \text { с реперфузии с } \\
\text { 1-минутным индексом } \\
\text { реперфузии }\end{array}$ & $\begin{array}{l}\text { Сохранность миокарда через } \\
3 \text { мес по оценке с помощью МРТ }\end{array}$ & $\begin{array}{l}\text { Уменьшение на 19\% } \\
\text { зоны инфаркта. } \\
\text { Повышение на 31\% со- } \\
\text { отношения сохранности } \\
\text { миокарда }\end{array}$ \\
\hline
\end{tabular}

демонстрировали кардиопротективные эффекты посткондиционирования.

Эти небольшие клинические исследования ишемического посткондиционирования оказались перспективными и показали потенциал посткондиционирования, улучшающего как ранние маркеры размера инфаркта, так и функцию миокарда спустя 1 год после инфаркта (см. табл.). Основным ограничением для проведения ишемического посткондиционирования является то, что его можно выполнять только в условиях катетеризационной лаборатории во время ЧКВ. Хотя польза от первичного ЧКВ хорошо известна, многие пациенты до сих пор получают тромболитическую терапию как метод реперфузии. Фармакологическое средство, которое имитирует эфффект посткондиционирования, должно вводиться пациентам в момент реперфузии независимо от способа введения.

В настоящее время циклоспорин наиболее перспективный фрармакологический имитатор посткондиционирования. Считается, что кардиопротективный эффрект циклоспорина происходит от ингибирования образования ПППМ - ключевого компонента летального реперфузионного повреждения [18]. ПППМ, по-видимому, образуется на ранних стадиях реперфузии в ответ на кальциевую перегрузку и образование активных форм кислорода, которые развиваются вместе с реперфузией [19]. Эта пора большого диаметра образуется во внутренней митохондриальной мембране и открывает свободный проход для всех молекул размером менее 1,5 кДа в митохондриальный матрикс, вызывая осмотическое набухание, повреждение и/или деструкцию митохондрий.

Кроме того, внутренняя мембрана становится свободно проницаемой для протонов, разобщающих окислительное фосфрорилирование и нарушающих синтез АТФ [20]. Существует большое количество доказательств у нескольких животных, показывающих, что за счет ингибирования образования ПППМ циклоспорин может значительно уменьшить зону инфаркта при введении во время реперфузии [18, 19]. Интересно, что некоторые кардиопротективные эфффекты, наблюдаемые при пре- и посткондиционировании, обусловленные ингибированием образова- ния ПППМ, показывают общий путь, объединяющий эти фрормы защиты [21].

В небольшом доказательном клиническом исследовании Piot и соавт. [22] продемонстрировали, что циклоспорин, введенный во время ЧКВ, может уменьшить размер инфаркта по сравнению с плацебо. 58 пациентов с ОИМ и ПСТ были рандомизированы для получения внутривенного болюса циклоспорина в дозе 2,5 мг/кг или физиологического раствора. Размер инфаркта, как было измерено с помощью КФК после реперфузии, был ниже на $40 \%$ в группе циклоспорина $(p=0,04)$ по сравнению с контрольной группой (138,053 условные единицы [межквартальный диапазон (МКД): от 114,008 до $283,461]$ для группы циклоспорина против 247,930 условных единиц [МКД: от 145,639 до 404,349] для контрольной группы). Средняя область под кривой концентрации тропонина I выявила тренд снижения в группе циклоспорина, но не была статистически значима. В подгруппе из 27 пациентов МРТ сердца проводили через 5 дней и 6 мес после инфаркта. Пациенты в группе циклоспорина имели значительно меньшую площадь «гиперусиления», чем пациенты в контрольной группе через 5 дней (37 g [МКД: от 21 до $51 \mathrm{~g}$ ] для леченных пациентов, против $46 \mathrm{~g}$ [МКД: от 20 до 65 g] для контрольной группы; $p=0,04)$. В последующем опубликованном докладе рассказывалось, что у тех же групп сохранялись значительные различия в размере инфаркта, измеренного с

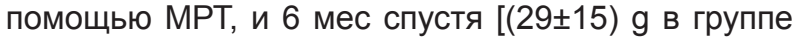
циклоспорина, против $(38 \pm 14) \mathrm{g}$ в контрольной группе; $p=0,04]$ [23]. В настоящее время ведется большое многоцентровое исследование, включающее примерно 1000 пациентов, чтобы исследовать циклоспорин как кардиопротективное средство.

Дистанционное ишемическое кондиционирование. Существует много накопленных доказательств, что ишемическое кондиционирование может ограничивать зону инфаркта миокарда, даже если его применять на сосуде, лежащем от органа дистанционно. Эта техника, известная как «дистанционное ишемическое кондиционирование», показала свои кардиопротективные свойства у различных животных при применении до ишемического события (дистанционное прекондиционирование) [24], после 
ишемического события (дистанционное посткондиционирование) $[25,26]$ и во время ишемического события (дистанционное кондиционирование) [27]. Практически дистанционное кондиционирование очень привлекательно, потому что даже ишемия конечности, индуцированная надуванием манжеты для измерения кровяного давления, может уменьшить ишемическое повреждение миокарда [27]. Механически кажется, что дистанционное кондиционирование активирует аналогичные сигнальные пути как в пре-, так и посткондиционировании; однако неизвестно как стимул кондиционирования, примененный к удаленному органу, способен защитить сердце. Современная теория предполагает, что неизвестное гуморальное вещество, которое высвобождается из кондиционируемого органа, оказывает свое действие на сердце $[28,29]$. Сигнал начинается с помощью аффрерентных нейронов в кондиционируемом органе и заканчивается эфферентными нейронами в сердце [30]. Дальнейшие исследования ведутся для выяснения основного механизма.

В недавнем исследовании, проводимом Botker [31], 333 пациента с ОИМ и ПСТ были рандомизированы, чтобы получать только ЧКВ или дистанционное ишемическое кондиционирование перед ЧКВ. Дистанционное кондиционирование начиналось еще в машине скорой помощи по пути в больницу и состояло из прерывистой ишемии руки через 4 цикла переменного 5-минутного раздувания манжеты до 200 мм рт.ст. и 5-минутного сдувания до стандартного верхнего уровня артериального давления. Первичной конечной точкой этого исследования был индекс спасения миокарда через 30 дней после ЧКВ, измеренного с помощью ПЭТ. Исследователи обнаружили значительное улучшение индекса спасения миокарда в группе кондиционирования по сравнению с контрольной $(0,69 \pm 0,27$ для леченных пациентов против $0,57 \pm 0,26$ для контрольной группы; $p=0,03)$. Была также тенденция, хотя статистически не значимая, в сторону меньшего окончательного размера инфаркта в

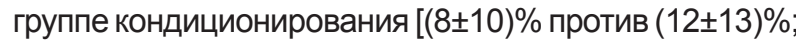
$p=0,10]$. Это исследование добавляется к растущей совокупности доказательств и наводит на мысль, что ишемическое кондиционирование является возможным и эффрективным в реальных клинических ситуациях. Кроме того, эта специфическая техника использования ишемии верхней левой конечности по пути в больницу заслуживает особого внимания ввиду ее удобства и эффективности. Большие клинические исследования ведутся для уточнения этой новой техники кардиопротекции.

Методы лечения, показывающие результат при строгом соблюдении условий

Мягкая гипотермия. Терапевтическая гипотермия - это хорошо изученный метод защиты ишемизированного миокарда от инфаркта. На нескольких животных были продемонстрированы кардиопротективные эффекты гипотермии, начиная от мягкой гипотермии (от 32 до $35^{\circ} \mathrm{C}$ ) до умеренной (от 28 до $32^{\circ} \mathrm{C}$ ), тяжелой (от 20 до $28^{\circ} \mathrm{C}$ ) и глубокой $\left(<20^{\circ} \mathrm{C}\right)$ гипотермии [32-36]. Хотя механизм защиты умеренной и тяжелой гипотермии, по-видимому, связан с замедлением метаболизма, то у мягкой гипотермии механизм защиты включает в себя изменения в сигнальных путях $[32,37]$. Интересно, что Yang и соавт. [38] недавно опубликовали исследование, в котором предположили, что сохранение активности внеклеточной сигналорегулируемой киназы благодаря мягкой гипотермии способствовало уменьшению размера инфаркта у кроликов [38]. Внеклеточная сигналорегулируемая киназа является членом защитных киназ группы киназ реперфузионного повреждения, которые участвуют в защите от ишемии-реперфузионного повреждения, и активированы в других методах кардиопротекции, таких как ишемическое кондиционирование.

Несколько ранних клинических исследований попытались перевести это преимущество на людей, но с ограниченным успехом [39]; впрочем, гипотермия действительно может ограничить зону инфаркта при определенных условиях. COOL-MI (Cooling as an Adjunctive Therapy to Percutaneous Intervention in Patients With Acute Myocardial Infarction) - это многоцентровое рандомизированное контролируемое клиническое исследование, которое оценивало эфффективность гипотермии в снижении размера инфаркта миокарда [39]. В этом исследовании из 357 пациентов 177 пациентов были рандомизированы для получения эндоваскулярного охлаждающего катетера (Reprieve, Radiant Medical, Redwood City, California), установленного в нижней полой вене через бедренную вену. Когда пациенты прибывали в катетеризационную лабораторию, гипотермия была вызвана циркуляцией охлажденного физиологического раствора через устройство, проходя по катетеру, тем самым охлаждая кровь. Хотя в этом исследовании не смогли показать общую разницу в размере инфаркта, исследователи заметили тенденцию, что у пациентов с передними ИМ, получавшими гипотермию, размер инфаркта был меньше, нежели у пациентов с нижними ИМ. Дальнейшие исследования продемонстрировали, что пациенты с передними ИМ, которые были охлаждены до температуры менее $35^{\circ} \mathrm{C}$ перед реперфузией, имели значительно меньшую зону инфаркта по сравнению с контрольной (9,3\% леченных пациентов против $18,2 \%$ контрольной; $p=0,05)$ у небольшого количества пациентов $(n=16)$.

Основным ограничением для COOL-MI было то, что только небольшому количеству пациентов до реперфузии удалось достичь заданной температуры менее $35^{\circ} \mathrm{C}$, вероятно, вследствие быстрого времени достижения баллона и медленного процесса охлаждения. Исследование RAPID-MI-ICE (Rapid Intravascular Cooling in Myocardial Infarction as Adjunctive to Percutaneous Coronary Intervention) было разработано, чтобы оценить безопасность и выполнимость быстро индуцированной гипотермии перед реперфузией [40]. Двадцать пациентов были рандомизированы для получения гипотермии или контроля. В дополнение к эндоваскулярному охлаждающему катетеру пациенты в группе гипотермии получали внутрисосудистую инфузию охлажденного фризиологического раствора от 1 до 2 л. Все пациенты в группе гипотермии достигали температуру тела менее $35^{\circ} \mathrm{C}$ перед реперфузией без существенных 
задержек во времени от места пункции до баллона. Было обнаружено, что быстро индуцированная гипотермия уменьшает размер инфаркта на $38 \%$ по сравнению с контрольной $[(29,8 \pm 12,6) \%$ в леченной группе против $(48,0 \pm 21,6) \%$ в контрольной; $p=0,04]$, как было измерено с помощью МРТ, которое выполнялось на 4-й день ( \pm 2 дня) после ИМ. Кроме того, не было замечено никаких побочных эффректов. Это пилотное исследование показало, что достижение температуры тела менее $35^{\circ} \mathrm{C}$ эфффективно уменьшает размер инфаркта и может вызываться быстро и безопасно без значительной задержки реперфузии или увеличения побочных эфффектов.

Терапия насыщенным кислородом (АМІHОТ I u II) остается еще несколько спорной, но летальное реперфузионное повреждение может играть важную роль в миокардиальном реперфузионном повреждении $[41,42]$. Несмотря на то что реперфузионное повреждение сложное и разрушающее, оно привлекательно для вспомогательной кардиопротективной терапии, потому что в отличие от начальной ишемии, момент реперфузии обычно контролируется. Дополнительной терапией, которая может ослабить реперфузионное повреждение, является гипероксигенация. В недавно опубликованном исследовании продемонстрирован этот эффрективный подход. АМІНОТ II (Acute Myocardial Infarction With Hyperoxemic Therapy II) была проспективным многоцентровым исследованием 301 пациента с передним ОИМ и ПСТ в течение 6 ч от начала симптомов [43]. Пациенты были рандомизированы, чтобы получать интракоронарную инфузию насыщенного кислорода в течение 90 мин сразу же после ЧКВ или стандартной медицинской помощи. Это исследование было разработано после разочаровывающих результатов AMIHOTI, в котором оценивалась гипероксигенационная терапия у пациентов с передним или обширным нижним ИМ в течение 24 ч от начала симптомов [44]. АМІНОТ I не смогла выполнить первичные конечные точки показателя степени тяжести изменения движения стенки в течение 3 мес, изменения ST-сегмента в течение 3 ч после ЧКВ и конечного размера инфаркта на период от 14-го до 21-го дня. Однако ретроспективный анализ показал возможную пользу для пациентов с передним ИМ через 6 ч от начала симптомов.

АМІНОТ II действительно продемонстрировала положительные результаты [43]. Используя Байесовское иерархическое моделирование, исследователи могли заимствовать данные пациентов, включенных в исследование АМІНОТ І, которые удовлетворяли критериям включения для АМІНОТ II. Это еще недостаточно используемая, но хорошо отработанная техника позволяет уменьшить размер выборки и, следовательно, приводит к более быстрому завершению основных клинических испытаний [45]. Когда данные исследований АМІНОТ I и II были объединены, было обнаружено, что размер инфраркта миокарда значительно уменьшился (25\% [МКД: от 7 до 42\%] в контрольной группе против 18,5\% [МКД: от 3,5 до 34,5\%] в леченной группе; $p=0,02$; Байесовская вероятность превосходства составила 96,9\%). Кроме того, у пациентов с исходной фракцией выброса ЛЖ менее 40\% размер инфаркта уменьшился с 33,5\% в контрольной до 23,5\% в группе лечения. Эти дополнительные 10\% сохранности миокарда гораздо лучше, чем 6,5\%, которые прослеживаются во всей изучаемой популяции, показывая тем самым, что эта терапия наиболее благотворна для пациентов с обширными инфарктами.

\section{Выводы и перспективы на будущее}

За последние 3 десятилетия мы стали свидетелями сотни потенциально кардиопротективных средств, которые пришли и ушли, так и не став распространенными в клинической практике. Причины этих неудач были подробно обсуждены и документированы в опубликованных отчетах [10]. В настоящее время доказана польза некоторых видов лечения в клинических испытаниях, и хотя необходимы дальнейшие исследования, мы действительно приближаемся к безопасному и эффрективному дополнению к реперфузии. Интересно, что кандидаты с наиболее большим потенциалом вовлекают различные методы лечения, и доклинические исследователи должны использовать несколько лабораторий и животных для того, чтобы увеличить вероятность успешной терапии в клинических испытаниях. Хотя быстрая реперфузия ишемизированного миокарда остается стандартом лечения ОИМ, мы должны стремиться уменьшить гибель клеток. С помощью таких исследований, как CAESAR, и усилий мультилабораторий [50] будущие крупные клинические исследования будут определять, какая терапия или комбинация терапий будет самой эффективной в достижении этой амбициозной, но досягаемой цели.

\section{ЛИТЕРАТУРА}

1. Heart and Stroke Statistics. American Heart Association. 2011. - Accessed, January 15, 2011. - URL: Available at: http://www.americanheart.org/statistics/index.html

2. Jaffe, A.S. Acute myocardial infarction: state of the art / A.S. Jaffe // Circulation. - 1986. — Vol. 74. - P.IV120123.

3. GUSTO Investigators. An international randomized trial comparing four thrombolytic strategies for acute myocardial infarction // N. Engl. J. Med. - 1993. Vol. 329. - P.673-682.

4. Gruppo Italiano per lo Studio della Streptochinasi nell'Infarto Miocardico (GISSI). Effectiveness of intravenous thrombolytic treatment in acute myocardial infarction // Lancet. — 1986. — Vol. 1. - P.397-402.

5. Gibbons, R.J. Immediate angioplasty compared with the administration of a thrombolytic agent followed by conservative treatment for myocardial infarction / R.J. Gibbons, D.R. Holmes, G.S. Reeder [et al.] // N. Engl. J. Med. - 1993. — Vol. 328. - P.685-691.

6. Grines, C.L. A comparison of immediate angioplasty with thrombolytic therapy for acute myocardial infarction / C.L. Grines, K.F. Browne, J. Marco [et al.] // N. Engl. J. Med. - 1993. - Vol. 328. - P.673-679.

7. Zijlstra, F. A comparison of immediate coronary angioplasty with intravenous streptokinase in acute myocardial infarction / F. Zijlstra, M.J. de Boer, J.C. Hoorntje // N. Engl. J. Med. - 1993. — Vol. 328. - P.680-684.

8. Fischman, D.L. A randomized comparison of coronarystent placement and balloon angioplasty in the treatment of coronary artery disease: Stent Restenosis Study Investigators / D.L. Fischman, M.B. Leon, D.S. Baim [et al.] // N. Engl. J. Med. - 1994. - Vol. 331. — P.496-501. 
9. Cucherat, $M$. Primary angioplasty versus intravenous thrombolysis for acute myocardial infarction / M. Cucherat, E. Bonnefoy, G. Tremeau. - Cochrane Database Syst. Rev. - 2000. - (2):CD001560.

10. Miura, T. Limitation of myocardial infarct size in the clinical setting: current status and challenges in translating animal experiments into clinical therapy / T. Miura, T. Miki // Basic. Res. Cardiol. - 2008. - Vol. 103. - P.501-513.

11. Murry, C.E. Preconditioning with ischemia: a delay of lethal cell injury in ischemic myocardium / C.E. Murry, R.B. Jennings, K.A. Reimer // Circulation. - 1986. Vol. 74. - P.1124-1136.

12. Yellon, D.M. Preconditioning the human myocardium / D.M. Yellon, A.M. Alkhulaifi, W.B. Pugsley // Lancet. 1993. - Vol. 342. - P.276-277.

13. Deutsch, E. Adaption to ischemia during percutaneous transluminal coronary angioplasty. Clinical, hemodynamic, and metabolic features / D.M. Yellon, A.M. Alkhulaifi, W.B. Pugsley // Circulation. - 1990. - Vol. 82. P.2044-2051.

14. Yellon, D.M. Preconditioning the myocardium: from cellular physiology to clinical cardiology / D.M. Yellon, J.M. Downey // Physiol. Rev. - 2003. - Vol. 83. - P.1113-1151.

15. Zhao, Z.Q. Inhibition of myocardial injury by ischemic postconditioning during reperfusion: comparison with ischemic preconditioning / Z.Q. Zhao, J.S. Corvera, M.E. Halkos [et al.] // Am. J. Physiol. Heart Circ. Physiol. 2003. - Vol. 285. - P.H579-588.

16. Staat, P. Postconditioning the human heart / P. Staat, G. Rioufol, C. Piot [et al.] // Circulation. - 2005. Vol. 112. - P.2143-2148.

17. Laskey, W.K. Concordant improvements in coronary flow reserve and ST-segment resolution during percutaneous coronary intervention for acute myocardial infarction: a benefit of postconditioning / W.K. Laskey, S. Yoon, N. Calzada, M.J. Ricciardi // Catheter Cardiovasc. Interv. 2008. - Vol. 72. - P.212-220.

18. Hausenloy, D.J. Inhibiting mitochondrial permeability transition pore opening: a new paradigm for myocardial preconditioning? / D.J. Hausenloy, H.L. Maddock, G.F. Baxter, D.M. Yellon // Cardiovasc. Res. - 2002. Vol. 55. - P.534-543.

19. Griffiths, E.J. Mitochondrial non-specific pores remain closed during cardiac ischaemia but open upon reperfusion / E.J. Griffiths, A.P. Halestrap // Biochem. J. — 1995. Vol. 307. - P.93-98.

20. Halestrap, A.P. What is the mitochondrial permeability transition pore? / A.P. Halestrap // J. Mol. Cell. Cardiol. 2009. - Vol. 46. - P.821-831.

21. Hausenloy, D.J. Preconditioning and postconditioning: united at reperfusion / D.J. Hausenloy, D.M. Yellon // Pharmacol. Ther. - 2007. - Vol. 116. - P.173-191.

22. Piot, C. Effect of cyclosporine on reperfusion injury in acute myocardial infarction / C. Piot, P. Croisille, P. Staat [et al.] // N. Engl. J. Med. - 2008. — Vol. 359. - P.473-481.

23. Mewton, N. Effect of cyclosporine on left ventricular remodeling after reperfused myocardial infarction / N. Mewton, P. Croisille, G. Gahide [et al.] // J. Am. Coll. Cardiol. - 2010. - Vol. 55. - P.1200-1205.

24. Przyklenk, K. Regional ischemic 'preconditioning' protects remote virgin myocardium from subsequent sustained coronary occlusion / K. Przyklenk, B. Bauer, M. Ovize [et al.] // Circulation. - 1993. - Vol. 87. P.893-899.

25. Kerendi, F. Remote postconditioning. Brief renal ischemia and reperfusion applied before coronary artery reperfusion reduces myocardial infarct size via endogenous activation of adenosine receptors / F. Kerendi, H. Kin, M.E. Halkos [et al.] // Basic. Res. Cardiol. - 2005. - Vol. 100. P.404-412.
26. Andreka, G. Remote ischaemic postconditioning protects the heart during acute myocardial infarction in pigs / G. Andreka, M. Vertesaljai, G. Szantho [et al.] // Heart. 2007. - Vol. 93. - P.749-752.

27. Schmidt, M.R. Intermittent peripheral tissue ischemia during coronary ischemia reduces myocardial infarction through a KATP-dependent mechanism: first demonstration of remote ischemic preconditioning / M.R. Schmidt, M. Smerup, I.E. Konstantinov [et al.] // Am. J. Physiol. Heart Circ. Physiol. — 2007. - Vol. 292. - P.H1883-1890.

28. Gho, B.C. Myocardial protection by brief ischemia in noncardiac tissue / B.C. Gho, R.G. Schoemaker, M.A. van den Doel [et al.] // Circulation. - 1996. - Vol. 94. P.2193200.

29. Dickson, E.W. Rabbit heart can be «preconditioned» via transfer of coronary effluent / E.W. Dickson, M. Lorbar, W.A. Porcaro [et al.] // Am. J. Physiol. - 1999. Vol. 277. - P.H2451-2457.

30. Loukogeorgakis, S.P. Remote ischemic preconditioning provides early and late protection against endothelial ischemia-reperfusion injury in humans: role of the autonomic nervous system / S.P. Loukogeorgakis, A.T. Panagiotidou, M.W. Broadhead [et al.] // J. Am. Coll. Cardiol. - 2005. - Vol. 46. - P.450-456

31. Botker, H.E. Remote ischaemic conditioning before hospital admission, as a complement to angioplasty and effect on myocardial salvage in patients with acute myocardial infarction: a randomised trial / H.E. Botker, R. Kharbanda, M.R. Schmidt [et al.] // Lancet. — 2010. Vol. 375. - P.727-734

32. Tissier, $R$. The small chill: mild hypothermia for cardioprotection? / R. Tissier, M. Chenoune, B. Ghaleh [et al.] // Cardiovasc. Res. - 2010. — Vol. 88. - P.406414.

33. Miki, T. Mild hypothermia reduces infarct size in the beating rabbit heart: a practical intervention for acute myocardial infarction? / T. Miki, G.S. Liu, M.V. Cohen, J.M. Downey // Basic Res. Cardiol. - 1998. - Vol. 93. - P.372-383.

34. Chen, Q. Cardiac preconditioning with $4-\mathrm{h}, 17^{\circ} \mathrm{C}$ ischemia reduces [Ca2] i load and damage in part via KATP channel opening / Q. Chen, A.K. Camara, J. An [et al.] // Am. J. Physiol. Heart Circ. Physiol. - 2002. - Vol. 282. P.H1961-1969.

35. Chenoune, M. Rapid cooling of the heart with total liquid ventilation prevents transmural myocardial infarction following prolonged ischemia in rabbits / $\mathrm{M}$. Chenoune, F. Lidouren, B. Ghaleh [et al.] // Resuscitation. - 2010. Vol. 81. - P.359-362.

36. Hale, S.L. Mild hypothermia as a cardioprotective approach for acute myocardial infarction: laboratory to clinical application / S.L. Hale, R.A. Kloner // J. Cardiovasc. Pharmacol. Ther. - 2011. - Vol. 16. - P.131-139.

37. Simkhovich, B.Z. Metabolic mechanism by which mild regional hypothermia preserves ischemic tissue / B.Z. Simkhovich, S.L. Hale, R.A. Kloner // J. Cardiovasc. Pharmacol. Ther. - 2004. - Vol. 9. - P.83-90.

38. Yang, $X$. Cardioprotection by mild hypothermia during ischemia involves preservation of ERK activity / X. Yang, Y. Liu, X.M. Yang [et al.] // Basic Res. Cardiol. - 2011. Vol. 106. - P.421-430.

39. O'Neill, W.W. Cooling as an Adjunctive Therapy to Percutaneous Intervention in Patients with Acute Myocardial Infarction (COOLMI) / W.W. O'Neill // Transcatheter Cardiovascular Therapeutics Session; September 15-19. - Washington: DC, 2003.

40. Götberg, M. A pilot study of rapid cooling by cold saline and endovascular cooling before reperfusion in patients with ST-elevation myocardial infarction / M. Götberg, G.K. Olivercrona, S. Koul [et al.] // Circ. Cardiovasc. Interv. - 2010. — Vol. 3. - P.400-407. 
41. Yellon, D.M. Myocardial reperfusion injury / D.M. Yellon, D.J. Hausenloy // N. Engl. J. Med. — 2007. — Vol. 357. — P.1121-1135.

42. Braunwald, E. Myocardial reperfusion: a double-edged sword? / E. Braunwald, R.A. Kloner // J. Clin. Invest. 1985. - Vol. 76. - P.1713-1719.

43. Stone, G.W. Effect of supersaturated oxygen delivery on infarct size after percutaneous coronary intervention in acute myocardial infarction / G.W. Stone, J.L. Martin, M.J. de Boer [et al.] // Circ. Cardiovasc. Interv. — 2009. Vol. 2. - P.366-375.

44. O'Neill, W.W. Acute Myocardial Infarction With Hyperoxemic Therapy (AMIHOT): a prospective, randomized trial of intracoronary hyperoxemic reperfusion after percutaneous coronary intervention / W.W. O'Neill, J.L. Martin, S.R. Dixon [et al.] // J. Am. Coll. Cardiol. - 2007. Vol. 50. - P.397-405.

45. Pennello, G. Experience with reviewing Bayesian Medical Device Trials / G. Pennello, L. Thompson // J. Biopharm. Stat. - 2008. - Vol. 18. - P.81-115.

46. Laskey, W.K. Brief repetitive balloon occlusions enhance reperfusion during percutaneous coronary intervention for acute myocardial infarction: a pilot study / W.K. Laskey // Catheter Cardiovasc. Interv. — 2005. - Vol. 65. P.361-367.

47. Ma, X. Effect of postconditioning on coronary blood flow velocity and endothelial function and LV recovery after myocardial infarction / X. Ma, X. Zhang, C. Li, M. Luo // J. Interv. Cardiol. - 2006. - Vol. 19. P.367-375.

48. Thibault, $H$. Long-term benefit of postconditioning / H. Thibault, C. Piot, P. Staat [et al.] // Circulation. 2008. - Vol. 117. - P.1037-1044.

49. Lonborg, J. Cardioprotective effects of local ischemic postconditioning in patients treated with primary percutaneous coronary intervention, evaluated by magnetic resonance / J. Lonborg, H. Kelbaek, N. Vejlstrup [et al.] // Circ. Cardiovasc. Interv. — 2010. - Vol. 3. P.34-41.

50. Baxter, G.F. Adenosine A1 Agonist at Reperfusion Trial (AART): results of a three-center, blinded, randomised, controlled experimental infarct study / G.F. Baxter, S.L. Hale, T. Miki [et al.] // Cardiovasc. Drugs. Ther. 2000. - Vol. 14. - P.607-614. 


\title{
ЭЛЕКТРОННЫЕ СИГАРЕТЫ - «СПОСОБ КУРЕНИЯ» ИЛИ СРЕДСТВО ОТКАЗА ОТ КУРЕНИЯ? КОММЕНТАРИЙ К СТАТЬЕ В.Д. МЕНДЕЛЕВИЧА
}

ПЕТР КАЗИМИРОВИч ЯБЛОНСКИЙ, докт. мед. наук, проф., директор ФГБУ «Санкт-Петербургский научно-исследовательский институт фтизиопульмонологии» Минздрава России, Санкт-Петербург, Россия, тел. 8-812-579-25-54, e-mail: spbniif_all@mail.ru

ОЛЬГА АНАТОЛЬЕВНА СУХОВСКАЯ, докт. биол. наук, рУководитель консультативного телефонного центра помощи в отказе от потребления табака ФГБУ “Санкт-Петербургский научно-исследовательский институт фтизиопульмонологии" Минздрава России, Санкт-Петербург, Россия, тел. 8-800-200-02-00, e-mail: ktc01@mail.ru

\begin{abstract}
Реферат. Статья представляет собой комментарий к статье В.Д. Менделевича, опубликованной во втором выпуске 8-го тома журнала «Вестник современной клинической медицины» [7]. Представлены международные документы, являющие основой борьбы с курением табака в мире. Авторы считают, что электронные сигареты (ЭС) и электронные средства доставки никотина (ЭСДН) не могут быть рекомендованы для лечения табачной зависимости, отмечают, что в нашей стране есть зарегистрированные лекарственные средства с более высокой эффективностью лечения табачной зависимости. Врач или медицинский работник, обученный проведению когнитивно-поведенческой терапии и оказанию помощи в отказе от табакокурения, способен при индивидуальном консультировании по отказу от курения в 1,84 раза повысить шансы долгосрочного отказа от курения. Оспорено то, что ЭС являются терапевтическим средством, и потому они не могут быть рекомендованы врачом. Ключевые слова: электронные сигареты, отказ от курения, табачная зависимость.
\end{abstract}

\section{ELECTRONIC CIGARETTES - «WAY OF SMOKING» OR QUIT SMOKING DEVICES? COMMENTARY ARTICLE ON V.D. MENDELEVICH}

\begin{abstract}
PETER K. YABLONSKY, Doctor of Medical Science, Professor, Director of FSBI «Saint Petersburg Research Institute for Phthisiopulmonology» of Russian Ministry of Health, Saint Petersburg, Russia, tel. 8-812-579-25-54, e-mail: spbniif_all@mail.ru OLGA A. SUKHOVSKAYA, Doctor of Medical Science, Head of the advisory call center for tobacco consumption quitting of FSBI «Saint Petersburg Research Institute for Phthisiopulmonology» of Russian Ministry of Health, Saint Petersburg, Russia, tel. 8-800-200-02-00, e-mail: ktc01@mail.ru
\end{abstract}

\begin{abstract}
The article is a comment on V.D. Mendelevich's article published in Bulletin of modern clinical medicine Vol. 8 Issue 2 [7]. International statements, as the basis of the fight against tobacco smoking in the world are presented. The authors believe that electronic cigarettes (ES) and electronic nicotine delivery systems (ENDS) can not be recommended for tobacco addiction treatment. Also noted, that our country has registered medications for tobacco addiction treatment with higher efficiency. Doctor or health care worker trained in carrying out cognitive behavioral therapy and assistance in quitting smoking, is capable to increase the chances of long-term smoking cessation in 1,84 times at individual counseling for smoking cessation. We disputed the conception ES as a therapeutic agent, and that's why they can not be recommended by physicians.
\end{abstract}

Key words: electronic cigarettes, smoking cessation, tobacco addiction.

$\mathrm{B}$ последние годы появилось множество публикаций, посвященных электронным сигаретам (ЭС) и электронным средствам доставки никотина (ЭСДН). Этот интерес вызван, в первую очередь, принятием в развитых странах законов, ограничивающих курение табака. Их принятие привело к значительному (2-3-кратному) снижению числа курящих.

Однако с 2008 г. отмечается увеличение использования ЭСДН и, в частности, ЭС. В 2014 г. насчитывалось 466 брендов ЭСДН, а в 2013 г. на ЭСДН в мире было израсходовано около 3 млрд долл. США [1]. Согласно опубликованным дан- ным, с 2008 по 2012 г. использование ЭСДН среди взрослых и подростков возросло, по крайней мере, в 2 раза [2]. В связи с растущим потреблением ЭСДН на 5-й сессии (12-17 ноября 2012 г.) конференции сторон Рамочной конвенции по борьбе против табака (КС РКБТ) было принято решение об изучении фактических данных о последствиях использования ЭСДН для здоровья, определения возможных путей их предупреждения и борьбы с ними. Такой доклад был представлен экспертами ВОЗ на 6-й сессии КС РКБТ в октябре 2014 г. [3]. Сформулированные в докладе вопросы по ЭСДН делятся на три группы: 
а) риски для здоровья пользователей и тех, кто ими не является;

b) помехи для предпринимаемых усилий по борьбе против табака и для осуществления РКБТ ВОЗ;

с) эффрективность помощи курильщикам в прекращении курения.

Оценки рисков для здоровья. В докладе экспертов ВОЗ [3] говорится о том, что ЭСДН не являются безопасными, формируют зависимость, а при переходе с сигарет на них из-за отсутствия ограничений на курение в общественных местах эта зависимость может усиливаться и приводить к увеличению случаев передозировки никотином.

Помехи для предпринимаемых усилий по борьбе против табака и для осуществления РКБТ ВОЗ. Вызывает обеспокоенность формирование убеждений о безопасности курения ЭС. Это может привести к тому, что курящие люди вместо отказа от курения табака перейдут на использование ЭС. Особенно это актуально для нашей страны, так как в настоящее время в стране курят табачные изделия большинство взрослых мужчин и большинство женщин репродуктивного возраста $[4,5,6]$. В отличие от стран Западной Европы и США, в которых распространение ЭС началось уже после того, как большая часть курящих, способных отказаться от ТК, бросила курить, и в обществе сформировалось негативное отношение к ТК, в нашей стране пропаганда ЭСДН может привести к их постоянному использованию даже теми курящими, которые могли бы полностью отказаться от ТК.

Эфффективность помощи курильщикам в прекращении курения. В докладе ВОЗ сделан вывод о том, что фрактические данные об эфффективности ЭСДН в качестве метода прекращения ТК являются ограниченными и не позволяют делать выводы [3]. Об этом свидетельствуют и приведенные в статье [7] исследования.

Статья 5.2(b) Рамочной конвенции по борьбе против табака (РКБТ), к которой присоединилась и Россия, обязывает Стороны предотвращать и сокращать потребление табака и воздействие табачного дыма, предотвращать и сокращать аддикцию к никотину, независимо от его источника. Поэтому можно согласиться с выводом автора статьи «Польза и вред электронных сигарет сквозь призму разных терапевтических методологий» о том, что «обобщая результаты десятков корректных научных исследований, позволительно констатировать, что эффрективность использования ЭС как средства, направленного на полный отказ от курения, обнаружило большой разброс данных от 7,3\% до 19\% 6-месячной ремиссии. По данному параметру ЭС уступает применению многих лекарственных средств». Это не позволяет рекомендовать ЭС для лечения табачной зависимости, тем более, что в нашей стране есть зарегистрированные лекарственные средства с более высокой эфффективностью лечения табачной зависимости.

Теперь о том, с какими пациентами медикам приходится иметь дело и о стратегии снижения вреда.

Согласно опросу, проведенному в 2009 г. Министерством здравоохранения РФ и ВО3 (GAST, 2009), и эпидемиологическим исследованиям в нашей стане более $60-70 \%$ курящих хотели бы бросить курить $[4,8]$. Этим людям необходим короткий совет врача по прекращению курения и помощь в отказе от курения.

Результаты метаанализа показывают, что короткий совет врача (при оценке через 6-12 мес) увеличивает шансы отказа от курения по сравнению с самостоятельным отказом в 1,66 раза $(95 \% \mathrm{Cl} 1,42-$ 1,94) [9]. Короткий совет врача требует 3-10 мин. Он включает рекомендацию по прекращению курения и связь состояния больного с ТК. Если пациент не готов бросить курить, короткий совет врача включает краткую рекомендацию с акцентами на последствия курения для его здоровья и преимущества отказа от курения («табачный дым способствует развитию легочной гипертензии, поэтому очень важно для вас не курить», «ТК способствует прогрессирующему снижению вентиляционной функции легких, советую вам отказаться от курения сейчас»), выяснение причин, по которым пациент не хочет бросать курить (чаще всего это опасения по опыту прошлых попыток, что не удастся отказаться от курения или боязнь стресса, который служит основной причиной курения). В заключение целесообразно дать адрес сайтов по здоровому образу жизни Министерства здравоохранения Российской Федерации (www. takzdorovo.ru) и сайта Консультативного телефонного центра помощи в отказе от потребления табака (http://www.spbniif.ru/antitabak.html) [10], посоветовав внимательно изучить последствия ТК на здоровье и методы помощи в отказе от курения.

При наличии возможности врач или медицинский работник, обученный проведению когнитивноповеденческой терапии и оказанию помощи в отказе от ТК, может провести индивидуальное консультирование по отказу от курения, которое занимает 10-20 мин. Более длительное консультирование увеличивает шансы долгосрочного отказа от курения в 1,84 раза (95\% Cl 1,60-2,13) по сравнению с отсутствием совета врача и в 1,37 раза по сравнению с коротким советом врача (95\% Cl 1,20-1,56) [9].

В заключение пациент должен получить информацию о том, где и как он может получить помощь при отказе от ТК, и ему необходимо рекомендовать обращение в Консультативный телефонный центр помощи в отказе от потребления табака по телефону 8-800-200-02-00.

В отличие от опиоидной наркомании структура личности при ТК не разрушается, есть возможность изменить когнитивные установки и создать другую доминанту, научить справляться с синдромом отмены (использовав поведенческие методики) и тем самым преодолеть страх неудачи, мотивировать на отказ от ТК. Поэтому помощь курящим во всех странах, добившихся успехов по снижению распространенности ТК, включает когнитивно-поведенческую терапию, т.е. настрой на успех, обучение методам самопомощи при возникновении желания курить и стрессах. Эта стратегия эффрективна и в нашей стране, как показал опыт работы Консультативного телефонного центра помощи в отказе от потребления табака, организованного Министерством 
здравоохранения Российской Федерации в СПбНИИ фртизиопульмонологии [10].

Стратегия снижения вреда. В своей работе В.Д. Менделевич [7] предлагает рекомендовать курящим пациентам использование ЭС в качестве «одного из вариантов терапевтических программ». Во-первых, необходимо напомнить, что согласно Федеральному закону № 15 «Об охране здоровья граждан от воздействия окружающего табачного дыма и последствий потребления табака» запрещено использование электронных изделий в форме сигарет (ст.16), поэтому врач не имеет права давать такие рекомендации. Во-вторых, если мы будем говорить не только об ЭС, но и об ЭСДН, то российская делегация КС РКБТ вышла с предложением о полном запрете любых ЭСДН немедицинского назначения. Это связано с неконтролируемым выпуском ЭСДН и картриджей, отсутствием четких инструкций по их использованию и сведений о содержании в них никотина, что может способствовать усилению никотиновой зависимости при их применении.

Конечно, всегда будут люди, которые не захотят прекращать курение, и поиск безопасных способов потребления никотина для снижения токсического воздействия табачного дыма на курящего пациента и окружающих его людей оправдан. Однако усилия общества должны быть направлены на использование в таких ситуациях уже имеющихся медицинских средств доставки никотина (трансдермальные пластыри, жевательные резинки и т.п.). Возможна в будущем и разработка медицинских ингаляционных устройств доставки никотина, при этом эти устройства не должны имитировать процесс курения (чтобы не поддерживать ритуалы курения), а их назначение должно определяться лечащим врачом.

В заключение необходимо подчеркнуть, что имеющиеся в продаже электронные средства доставки никотина и, в частности, электронные сигареты не являются терапевтическим средством и не могут быть рекомендованы врачом. Эти устройства должны позиционироваться только как «средства для курения» (средства доставки никотина в организм человека), и к ним должны быть применены все положения закона наравне с табачными изделиями.

\section{ЛИТЕРАТУРА}

1. Zhu, S.-H. Four hundred and sixty brands of e-cigarettes and counting: implications for product regulation / S.-H. Zhu, J.Y. Sun, E. Bonnevie [et al.] // Tobacco Control. - 2014. - Vol. 23. - P.iii3-iii9. — doi:10.1136/ tobaccocontrol-2014-051670

2. Grana, R. E-cigarettes: a scientific review/ R. Grana, N. Benowitz, S.A. Glantz // Circulation. 2014. - Vol. 129. - P.e490-e492. — doi:10.1161/ CIRCULATIONAHA. 114.008545

3. Доклад ВОЗ «Electronic nicotine delivery systems». URL: http://apps. who.int/gb/fctc/PDF/cop6/FCTC_ COP6_10-en.pdf?ua=1

4. Глобальный опрос взрослого населения о потреблении табака (GATS); Российская Федерация. - М., 2009. - $171 \mathrm{c}$.

5. Суховская, О.А. Социальные аспекты табакокурения женщин / О.А. Суховская, О.В. Лаврова, Е.А. Шапо- валова // Журнал акушерства и женских болезней. 2011. — № 2. - С.115-119.

6. Амиров, Н.Б. Табачная эпидемия: фрармакологические возможности борьбы / Н.Б. Амиров, Т.И. Андреева // Вестник современной клинической медицины. 2011. - Т. 4, вып. 3. - С.28-33.

7. Менделевич, В.Д. Польза и вред электронных сигарет сквозь призму разных терапевтических методологий / В.Д. Менделевич // Вестник современной клинической медицины. - 2015. - Т. 8, № 2. - С.61-73.

8. Суховская, О.А. Помощь при отказе от курения / О.А. Суховская // Доктор.pу. - 2010. - Т. 6, № 57. C. $41-44$

9. Stead, L.F. Physician advice for smoking cessation / L.F. Stead, G. Bergson, T. Lancaster // The Cochrane Library. - 2008. - Issue 4.

10. Яблонский, П.К. Организация консультативной телефонной помощи при отказе от табакокурения в Российской Федерации / П.К. Яблонский, О.А. Суховская // Здравоохранение Российской Федерации. - 2014. № $1 .-$ C.30-33.

\section{REFERENCES}

1. Zhu, S.-H. Four hundred and sixty brands of e-cigarettes and counting: implications for product regulation / S.-H. Zhu, J.Y. Sun, E. Bonnevie [et al.] // Tobacco Control. — 2014. — Vol. 23. — P.iii3-iii9. — doi:10.1136/ tobaccocontrol-2014-051670

2. Grana, R. E-cigarettes: a scientific review / R. Grana, N. Benowitz, S.A. Glantz // Circulation. 2014. - Vol. 129. - P.e490-e492. - doi:10.1161/ CIRCULATIONAHA. 114.008545

3. Doklad VOZ «Electronic nicotine delivery systems». URL: http://apps. who.int/gb/fctc/PDF/cop6/FCTC_ COP6_10-en.pdf?ua=1

4. Global'nyi opros vzroslogo naseleniya o potreblenii tabaka (GATS) [A global survey of the adult tobacco consumption (GATS)]; Rossiiskaya Federaciyay. - M., 2009. - $171 \mathrm{~s}$.

5. Suhovskaya, O.A. Social'nye aspekty tabakokureniya zhenschin [Social aspects of female tobacco consumption] / O.A. Suhovskaya, O.V. Lavrova, E.A. Shapovalova // Zhurnal akusherstva i zhenskih boleznei. - 2011. № 2. - C.115-119.

6. Amirov, N.B. Tabachnaya epidemiya: farmakologicheskie vozmozhnosti bor'by [Tobacco epidemic: pharmacological possibilities of struggle] / N.B. Amirov, T.I. Andreeva // Vestnik sovremennoi klinicheskoi mediciny [Bulletin of Contemporary Clinical Medicine]. - 2011. - T. 4, vyp. 3. - S.28-33.

7. Mendelevich, V.D. Pol'za i vred elektronnyh sigaret skvoz' prizmu raznyh terapevticheskih metodologii [Benefits and harm of electronic cigarettes through the prism of different therapeutic methodologies] / V.D. Mendelevich // Vestnik sovremennoi klinicheskoi mediciny [Bulletin of Contemporary Clinical Medicine]. - 2015. - T. 8, № 2. - C.61-73.

8. Suhovskaya, O.A. Pomosch' pri otkaze ot kureniya [Help with smoke quitting] / O.A. Suhovskaya // Doktor.ru. 2010. - T. 6, № 57. — S.41-44.

9. Stead, L.F. Physician advice for smoking cessation / L.F. Stead, G. Bergson, T. Lancaster // The Cochrane Library. - 2008. - Issue 4.

10. Yablonskii, P.K. Organizaciya konsul'tativnoi telefonnoi pomoschi pri otkaze ot tabakokureniya $v$ Rossiiskoi Federacii [Organization of telephone advisory help in smoking cessation in the Russian Federation] / P.K. Yablonskii, O.A. Suhovskaya // Zdravoohranenie Rossiiskoi Federacii. — 2014. — № 1. - C.30-33. 


\title{
ПУБЛИКАЦИОННАЯ ЭТИКА И РЕДАКЦИОННАЯ ПОЛИТИКА ЖУРНАЛА «ВЕСТНИК СОВРЕМЕННОЙ КЛИНИЧЕСКОЙ МЕДИЦИНЫ»
}

НАИЛЬ БАГАУВИЧ АМИРОВ, докт. мед. наук, проф. кафедры общей врачебной практики ГБОУ ВПО

«Казанский государственный медицинский университет» Минздрава России, заслуженный деятель науки и образования, акад. РАЕ, заслуженный врач РТ, лауреат Гос. премии РТ в области науки и техники, главный редактор журнала «Вестник современной клинической медицины», Казань, Россия, e-mail: namirov@mail.ru

АЛЕКСАНДР АНДРЕЕВИЧ ВИЗЕЛЬ, ДоКТ. меД. наук, проф., зав. кафедрой фтизИопуЛьмонологии ГБОУ ВПО «Казанский государственный медицинский университет» Минздрава России, заслуженный врач РТ, лауреат Гос. премии РТ в области науки и техники, зам. главного редактора журнала «Вестник современной клинической медицины», Казань, Россия, e-mail: lordara@inbox.ru

МАРИЯ АНАТОЛЬЕВНА ДАМИНОВА, канд. мед. наук, ассистент кафедры педиатрии и неонатологии ГБОУ ДПО «Казанская государственная медицинская академия» Минздрава России, ученый секретарь журнала «Вестник современной клинической медицины», Казань, Россия, тел. +7-917-262-47-79, e-mail: daminova-maria@yandex.ru PЕНАТА НАИЛЕВНА АМИРОВА, врач-эксперт ОАО СОГАЗ, руководитель отдела договоров и рекламы журнала «Вестник современной клинической медицины», Казань, Россия, тел. +7-903-307-99-47, e-mail: renata1980@mail.ru РУСТЕМ ИЛЬДАРОВИЧ ШАЙМУРАТОВ, аспирант кафедры фтизиопульмонологии ГБОУ ВПО

«Казанский государственный медицинский университет» Минздрава России, компьютерное сопровождение и версия журнала «Вестник современной клинической медицины» в Интернете, Казань, Россия, тел. +7-917-900-55-10, e-mail: russtem@gmail.com

Реферат. На современном этапе развития научной коммуникации для вхождения в международные базы данных журналы обязаны декларировать публикационную этику и редакционную политику. Для формирования конкретных рекомендаций с учетом последних требований было проведено исследование современных публикаций и международных документов. Рассмотрены вопросы этичности проведения научных исследований на человеке и животных, открытости публикаций. Даны определения критериев авторства, подробно описано понятие «конфрликт интересов авторов», в том числе и конфрликт интересов членов редколлегии при публикации «в собственном журнале». Описаны этические принципы рецензирования научных публикаций. Объяснено понятие «самоплагиат» и даны инструкции, как избежать самоплагиата при публикациях. Показаны критерии отклонения статей, и как редакция журнала поступает со статьями, подлежащими отклонению.

Ключевые слова: публикационная этика, редакционная политика, рецензирование, открытость публикаций.

\section{PUBLICATION ETHICS AND EDITORIAL POLICY OF JOURNAL "THE BULLETIN OF CONTEMPORARY CLINICAL MEDICINE»}

NAIL B. AMIROV, D.Med.Sci., Prof. of the Department of general medicine practice of SBEI HPE "Kazan State Medical University» of Russian Ministry of Health, Honored Science and Education Worker, Acad. of RANH, TR Honored Doctor, State Honoree of TR in Science and Technics, Editorial Board of journal «The Bulletin of Contemporary Clinical Medicine», Kazan, Russia, e-mail: namirov@mail.ru

ALEXANDER A. VIZEL, D.Med.Sci., Prof., Head of the Department of phthisiopulmonology of SBEl HPE «Kazan State Medical University" of Russian Ministry of Health, Honored Doctor of TR, State Honoree of TR in Science and Technics, Deputy Editor in chief of journal «The Bulletin of Contemporary Clinical Medicine», Kazan, Russia, e-mail: Iordara@inbox.ru MARIA A. DAMINOVA, C.Med.Sci., assistant of professor of Department of pediatrics and neonatology of SBEI APE «Kazan State Medical Academy» of Russian Ministry of Health, Responsible Secretary of journal «The Bulletin of Contemporary Clinical Medicine», Kazan, Russia, tel. +7-917-262-47-79, e-mail: daminova-maria@yandex.ru

RENATA N. AMIROVA, doctor-expert of Open joint-stock company ICGI, Chief of Marketing department of journal «The Bulletin of Contemporary Clinical Medicine», Kazan, Russia, tel. +7-903-307-99-47, e-mail: renata1980@mail.ru RUSTEM I. SHAYMURATOV, graduate student of the Department of phthisiopulmonology of SBEI HPE «Kazan State Medical University» of Russian Ministry of Health, computer support and web version of journal «The bulletin of contemporary clinical medicine», Kazan, Russia, tel. +7-917-900-55-10, e-mail: russtem@gmail.com

\begin{abstract}
In the modern era of scientific communication journals must declare publication ethics and editorial policy to be included in international databases. To develop specified up-to-date recommendations we studied the latest publications and international statements. In current article we discussed ethical aspects of biomedical research, publications transparency. Autorship criteria, conflict of interest and editorial board conflict of interest (when members of the editorial board publish in own journal) were described. Reviewer's ethics was also declared. We gave the definition of autoplagiarizm and provided instructions to avoid it. Retraction guidelines were also showed and information about how we treat articles that are ready to be retracted.
\end{abstract}

Key words: publication ethics, editorial policy, peer-review, transparency. 
Публикационная этика журнала «Вестник современной клинической медицины»

После удостоверения, что реферат и статья удовлетворяют правилам оформления статей и тезисов для авторов в журнал и приложения к журналу, начинается процесс рецензирования.

До рецензирования ответственный секретарь проверяет следующие аспекты:

- Имеет ли данное исследование научное обоснование с четко представленными целями и задачами, является ли размер выборки адекватным, четко ли представлены и объяснены результаты.

- Исследователи исключили или рассмотрели возможные искажающие факторы.

- Сведен к минимуму или отсутствует потенциальный вред субъекту исследования (обеспечение конфиденциальности персональных данных, снижение психоэмоциональной и фризической нагрузки).

- Преимущества исследования перевешивают вред.

Если у редакционной коллегии возникают вопросы по поводу соблюдения прав пациентов или соблюдения законов Российской Федерации, то мы вправе требовать от автора одобрения этического комитета [1]. Мы рекомендуем нашим авторам следовать Сингапурскому заявлению о добросовестности в исследованиях (www.singaporestatement. org): «Ценность и польза исследований целиком зависят от того, насколько добросовестно они выполняются. И хотя различия в организации и проведении исследований, определяемые национальным и дисциплинарным контекстом, вполне возможны и встречаются на практике, некоторые принципы и профессиональные обязательства имеют фундаментальное значение для добросовестности в исследованиях, где бы те ни проводились».

\section{Принципы:}

- Честность во всем, что связано с исследованием.

- Открытость хода и результатов исследования для внешнего контроля.

- Соблюдение норм профессиональной этики и уважительное отношение к коллегам.

- Квалисицированное проведение исследования в интересах всех тех, кого оно может затрагивать [2].

\section{Процесс рецензирования}

\section{Открытость публикаций}

Перед рецензированием рукописей ответственный секретарь удостоверяется, что авторы прочли и поняли Правила оформления статей и тезисов для авторов в журнал и приложения к журналу и ознакомились с публикационной этикой журнала, также он знакомится с заявлением автора, в котором освещены следующие пункты:

- Финансирование публикации.

- Декларация конфлликта интересов.

- Разрешение на копирование материалов из внешних источников (в том числе и из сети Интернет) при использовании таких материалов.
- Разрешение пациентов на публикацию их данных, а также проверка цензурирования данных пациентов, по которым можно установить их личность.

- Документированное подтверждение для любых цитат из неопубликованных работ (например, из статьи в печати, из выступлений на конференции, личных бесед).

- Информация о подаче данной публикации в другие журналы.

- Подтверждение, что рукопись не публиковалась ранее.

Каждый автор подписывает заявление об авторстве. Автором считается тот, кто принимал участие в разработке идеи, дизайна, обработки, анализа или интерпретации данных, правил черновики, критиковал, одобрял фринальную версию статьи. Редколлегия вправе запросить обязанности каждого автора в написании статьи. Как правило, автор, проделавший большую часть работы, идет в начале списка. С другой стороны, необходимо пояснить, что не каждый анализ и интерпретация данных (например, описание рентгеновских снимков) подпадает под критерий авторства.

Для исключения наличия в публикациях «авторов-гостей» и для включения «авторовпризраков» необходимо пояснить роль каждого автора в написании статьи. Возможно, некоторые авторы считают, что включение в статью человека, не принимавшего участия в ее написании «автора-гостя», - это рутинная практика в научном мире. По мнению редколлегии, данное поведение неэтично и неприемлемо, а также говорит о самооценке и самоуважении автора. Во избежание данной ошибки мы рекомендуем обсуждать эти вопросы заранее, до публикации. Всех лиц, не принимавших участие в написании публикации, мы советуем поместить в раздел «Благодарность». Обратной ситуацией является игнорирование «автора-призрака» - технического писателя, который только обрабатывал текст. Дело в том, что этот автор тоже имеет конфликт интересов, который должен декларироваться. Каждый автор должен участвовать в переписке с редколлегией (по меньшей мере, быть в копии переписки) в процессе принятия статьи и рецензирования, а не только автор-корреспондент. Автор-корреспондент - это административная роль.

В статье должны быть сведения об одобрении исследования этическим комитетом и об информированном согласии при исследовании на людях.

\section{Этика рецензентов}

Рецензенты, в свою очередь, должны:

- объективно проводить рецензирование;

- не допускать персональной критики автора, должны выражать свои взгляды ясно с аргументацией и ссылками, по мере необходимости должны декларировать конфоликт интересов;

- отказаться от обзора рукописей, в которых они имеют конфликт интересов в результате конкурентных, совместных или других отношений, или связей с любым из авторов, с любой компанией или любым учреждением; 
- соблюдать конфиденциальность материалов, предоставляемых на рецензию, и не должны обсуждать неопубликованные рукописи с коллегами или использовать информацию в своей работе. Если рецензент хочет передать запрос на отзыв коллеге, он должен получить разрешение редактора заранее.

При рецензировании рецензент проверяет следующие пункты:

- Была ли ранее опубликована работа. Был ли случай плагиата (или самоплагиата). Статьи проверяются с помощью поисковых систем и системы антиплагиат. Самоплагиатом считается цитирование самого себя слово в слово из предыдущих публикаций.

- Есть ли признаки фрабрикации данных или введение читателя в заблуждение.

- Есть ли в статье переработанный текст.

Переработанный текст - это частный случай автоплагиата, когда из публикации в публикацию повторяются одни и те же абзацы переработанного текста. Данное явление недопустимо, так как снижает качество и научную новизну публикации. Редколлегия оценивает, как много текста было переработано, где в статье встречается такой текст, есть ли ссылка на литературу. Отличить заимствование нескольких собственных фраз от переработки старой статьи совсем несложно. Если речь идет об описании технического метода, то переработанного текста, конечно, не избежать, но результаты и выводы исследования не должны повторяться. Если переработанный текст повторяется у данного автора в нескольких обзорных статьях, то согласно руководству комитета по публикационной этике (Beликобритания, http://publicationethics.org/resources/ guidelines), данная статья должна расцениваться как автоплагиат. Если авторы не дают ссылку на свою предыдущую работу, то это больше говорит об автоплагиате, чем о добросовестном заблуждении.

Так как такие клоны статей широко распространены, то есть и методические рекомендации по принятию их к публикации, вот несколько вариантов:

1. Авторы переписывают обзор литературы полностью за счет новых, ранее не цитированных источников.

2. Авторы цитируют собственный текст в кавычках или кратко и тезисно формулируют его с ОБЯЗАТЕЛЬНОЙ ссылкой на свои предыдущие публикации.

3. Авторы сокращают статью до тезисов или краткого сообщения со ссылкой на материалы и методы на предыдущую публикацию.

4. Авторы публикуют только расчеты и результаты со ссылкой на предыдущую публикацию и сравнивают их с аналогичными работами других авторов.

Любой из этих вариантов повысит оригинальность и цитируемость статьи.

При обнаружении переработанного текста в присланной статье редколлегия будет просить авторов переписать эти участки. При обнаружении в опубликованной статье переработанного текста статья будет отозвана или будет опубликована откорректированная статья за счет автора. Вопросы, касающиеся переработанного текста или авто- плагиата, рассматриваются с учетом компетенции автора, возраста и научного опыта.

\section{Публикация членов редколлегии в журнале}

Публикация членов редколлегии в журнале допускается. Процесс рецензирования этих рукописей происходит без участия авторов в обсуждении. Член редколлегии особо декларирует свой конфликт интересов с издателем и редакцией; член редколлегии не принимает участие в процессе рецензирования собственной статьи, общение с редакцией по вопросу публикации происходит только через ответственного секретаря.

Процесс рецензирования происходит независимо от учредителя. Все члены редколлегии имеют письменный договор с учредителем. Учредитель не имеет права влиять на процесс рецензирования.

Коммерческие публикации и рекламные объявления рассматриваются на общих основаниях с научными публикациями [3].

\section{Отклонение рукописей/отзыв статей} из печати

Рукописи отклоняются в случае, если:

- имеются явные признаки недостоверности публикуемых данных как намеренные, так и случайные;

- данные были опубликованы ранее;

- присутствует плагиат;

- исследование неэтичное;

- есть подозрения, что расследования, связанного с публикацией, не было или не будет справедливым и беспристрастным, или не будет убедительных доказательств обратного.

При смене авторов статьи, при условии надежности данных, отклоняться статьи не будут. Процедура отклонения статьи начинается как можно раньше с момента обнаружения поводов для отклонения, как правило, на этапе рецензирования. Напечатанные статьи могут быть отозваны. Процесс отклонения рукописей/отзыв статей из печати может быть инициирован как автором, так и редколлегией или другим журналом.

\section{Как мы поступаем со статьями, которые подлежат отклонению}

Если имеется возможность коррекции, то после устранения всех замечаний статья может быть принята к печати. Отклоняются статьи в основном с серьезными нарушениями.

Если напечатанная статья была опубликована ранее, то в следующем выпуске публикуется примечание со ссылкой на раннюю публикацию, в свою очередь, журнал «Вестник современной клинической медицины» отправляет извещение в издание, где статья была опубликована ранее.

«Перекрестные статьи». Статьи, содержащие в себе часть ранее опубликованных данных совместно с оригинальными данными, не отклоняются при наличии соответствующих ссылок. Целью процесса отклонения является не наказание авторов, а обеспечение достоверных данных [4]. 


\section{Конфликт интересов}

Каждый автор обязан декларировать конфрликт интересов, который возникает в условиях, когда на основной профессиональный интерес оказывает влияние вторичный интерес (финансовая выгода, продвижение по карьерной лестнице, поощрение коллег, друзей, родственников, соотечественников, выделение роли своей кафедры, учреждения). Влияние вторичного интереса приводит к моральноэтическим конфликтам по отношению к пациентам, работникам здравоохранения и научному сообществу в целом.

В медицине первичные профессиональные интересы связаны с качеством медицинской помощи, надлежащим лечением заболеваний, благополучием пациентов, профессионализмом, беспристрастным и добросовестным проведением научных исследований, а также честной и открытой редакторской работой. Вторичные интересы многочисленны, сложны по своему происхождению и не всегда легко различимы, даже для опытных специалистов. Они могут возникать из желания получить финансовую выгоду от профессиональных действий, чтобы укрепить позиции некоторых научных утверждений и продвинуть их, чтобы подняться по своей карьерной лестнице или по карьерной леснице членов семьи, друзей и коллег из того же города, страны или учреждения и др.
Конфрликт интересов может быть коммерческий (фринансовый), интеллектуальный, академический (соревновательный), идеологический, иметь личный характер или территориальные особенности.

Чаще всего возникает коммерческий конфликт интересов при публикации данных биомедицинских исследований. Необходимо декларировать спонсорство, гранты и иные виды материального поощрения.

При отсутствии конфликта интересов необходимо его декларировать. При сомнениях редколлегия всегда придет на помощь. Декларирование конфллкта интересов помогает читателям критически оценивать статью с учетом влияния вторичных интересов автора [5].

\section{ЛИТЕРАТУРА}

1. Guidance for Editors: Research, Audit and Service Evaluations. - URL: http://publicationethics.org/ resources/guidelines

2. URL: www.singaporestatement.org

3. A short guide to ethical editing for new editors. - URL: http://publicationethics.org/resources/guidelines

4. Retraction guidelines. - URL: http://publicationethics.org/ resources/guidelines

5. Gasparyan, A.Yu. Conflicts of interest in biomedical publications: considerations for authors, peer reviewers, and editors / A.Yu Gasparyan, L. Ayvazyan, N.A. Akazhanov, G.D. Kitas // Croat. Med. J. - 2013. - Vol.54. P.600-608

\title{
PUBLICATION ETHICS AND EDITORIAL POLICY OF JOURNAL «THE BULLETIN OF CONTEMPORARY CLINICAL MEDICINE»
}

NAIL B. AMIROV, D.Med.Sci., Prof. of the Department of general medicine practice of SBEI HPE «Kazan State Medical University» of Russian Ministry of Health, Honored Science and Education Worker, Acad. of RANH, TR Honored Doctor, State Honoree of TR in Science and Technics, Editorial Board of journal "The Bulletin of Contemporary Clinical Medicine», Kazan, Russia, e-mail: namirov@mail.ru

ALEXANDER A.VIZEL, D.Med.Sci., Prof., Head of the Department of phthisiopulmonology of SBEI HPE «Kazan State Medical University» of Russian Ministry of Health, Honored Doctor of TR, State Honoree of TR in Science and Technics, Deputy Editor in chief of journal «The Bulletin of Contemporary Clinical Medicine», Kazan, Russia, e-mail: Iordara@inbox.ru MARIA A. DAMINOVA, C.Med.Sci., assistant of professor of Department of pediatrics and neonatology of SBEI APE «Kazan State Medical Academy» of Russian Ministry of Health, Responsible Secretary of journal «The Bulletin of Contemporary Clinical Medicine», Kazan, Russia, tel. +7-917-262-47-79, e-mail: daminova-maria@yandex.ru

RENATA N. AMIROVA, doctor-expert of Open joint-stock company ICGI, Chief of Marketing department of journal «The Bulletin of Contemporary Clinical Medicine», Kazan, Russia, tel. +7-903-307-99-47, e-mail: renata1980@mail.ru RUSTEM I. SHAYMURATOV, graduate student of the Department of phthisiopulmonology of SBEI HPE «Kazan State Medical University» of Russian Ministry of Health, computer support and web version of journal "The bulletin of contemporary clinical medicine», Kazan, Russia, tel. +7-917-900-55-10, e-mail: russtem@gmail.com

\begin{abstract}
In the modern era of scientific communication journals must declare publication ethics and editorial policy to be included in international databases. To develop specified up-to-date recommendations we studied the latest publications and international statements. In current article we discussed ethical aspects of biomedical research, publications transparency. Autorship criteria, conflict of interest and editorial board conflict of interest (when members of the editorial board publish in own journal) were described. Reviewer's ethics was also declared. We gave the definition of autoplagiarizm and provided instructions to avoid it. Retraction guidelines were also showed and information about how we treat articles that are ready to be retracted.
\end{abstract}

Key words: publication ethics, editorial policy, peer-review, transparency.

\section{Publication Ethics of the Bulletin of Contemporary Clinical Medicine journal}

After submission an abstract or article (according to the rules of submitted manuscript) the peer-reviewing process begins. At the first stage, responsible secretary checks the following aspects:
- The study need to be scientifically valid with clearly aims and objectives. The sample size is adequate, and the results are adequately and clearly presented and explained.

- The investigators excluded or considered the possible confounding factors and/or biases. 
- The ethical harms been minimized; confidentiality protected, the risk of physical and psychological harm minimized.

- The benefits outweigh the harms in this particular study's case.

If there is doubt about local law or Russian Federation regulations, editors ask the authors to provide a letter from the ethics committee [1]. To provide the research integrity we offer our authors to follow Singapore Statement on Research Integrity (www. singaporestatement.org): "The value and benefits of research are vitally dependent on the integrity of research. While there can be and are national and disciplinary differences in the way research is organized and conducted, there are also principles and professional responsibilities that are fundamental to the integrity of research wherever it is undertaken».

\section{Principle:}

- Honesty in all aspects of research.

- Accountability in the conduct of research.

- Professional courtesy and fairness in working with others. [2].

- Good stewardship of research on behalf of others

\section{Peer-review}

Transparency

Before peer-review process, secretary assures that the authors have read and understood the Instructions to Authors, Publication Ethics guidelines and check author's statement (see below)

- Funding information.

- Competing interest declaration.

- Permission obtained for use of copyrighted material from other sources (including the Web).

- Documentation for any citations to unpublished work (e.g. articles in press/ personal communications)

- Information about previous submissions to other journals (e.g. name of journal, reviewer comments).

- Confirmation that the manuscript has been submitted solely to your journal and is not published, in press, or submitted elsewhere.

Each author signs an authorship declaration. Who is the Author? Author is the person who participated in article: created ideas, design, workflow, analyzed and interpreted the data, reviewed drafts, criticized and approved the final version of the article. Editorial board can require statements of each individual's contribution to the research and publication. As usual, Author performed the most work on the article is the first Author. On the other hand, we need to clarify that not all analyze and data interpretation refer to Authorship criteria (for example, X-ray interpretation as a part of the routine work).

To exclude guest-Authors and to include ghostAuthors please provide statements of each individual's contribution. Someone consider including to Author's list a person who did not contribute in article is a routine practice in scientific world. We think that such behavior is unethical and unacceptable. To avoid this we recommend discussing this before the publication.
All people who did not participate in the article we recommend to put in gratitude list after the main text. On the other hand, a "ghost writer" is frequently ignored. A technical writer who only processed the text have conflict of interest too which must be reported. All Authors must be in communications (e.g. acknowledging receipt of a submission) not just the corresponding Author.

An information letter from the ethics committee with study approval must exist in the article.

\section{Reviewers' ethics}

- Reviews conduct reviews objectively.

- Reviews avoid personal criticism of the Author.

- Reviewers decline to review manuscripts in which they have conflicts of interest resulting from competitive, collaborative, or other relationships or connections with any of the Authors, companies, or institutions connected to the papers.

- Reviewers respect the confidentiality of material supplied to them and should not discuss unpublished manuscripts with colleagues or use the information in their own work. If a reviewer wants to pass a review request onto a colleague, they should get the editor's permission beforehand.

\section{Reviewers should check ethical aspects of the submission such as:}

- Has the Author published this research before.

- Has the Author plagiarised another publication. Was it autoplagiarism. We check articles by antiplagiarism systems.

- Is there any indication that the data has been fabricated or inappropriately manipulated.

- Did the text has been recycled.

The recycled text is a special case of autoplagiarism - when from publication to publication Author repeats the same paragraphs of recycled text. This is unacceptable - autoplagiarism reduces the quality and scientific novelty of the publication. Editorial board evaluates how much text was recycled, if there is a reference to the literature is exist. Distinguish a few of their own borrowing phrases from the recycling of old articles is not difficult. When it comes to the materials and methods, the recycled text, of course, can not be avoided but the results and conclusions of the study should not be repeated. If the revised text repeated in Author's several review articles, according to the guidance of the Committee on Publication Ethics (UK, http://publicationethics.org/resources/guidelines) this article should be considered as autoplagiarism. If the Authors do not provide a link to his previous work, it speaks more in favor of autoplagiarism than an honest mistake.

Since those clones articles are widespread, to adopt them for publication, here are some options:

1. The Authors completely rewrite the review with new sources

2. The Authors cite own text in quotes or summarizes it with the obligatory reference to their previous publication.

3. The Authors cut the article to abstract size or a short message with reference to the materials and methods from the previous publication. 
4. The Authors publish only the results and calculations with reference to the previous publications and compare them with those or with other Authors.

Any of these options will enhance the originality and citation rate of the articles.

In case of detection a revised text in reviewing article, Editorial Board will ask the Authors to rewrite these parts. Upon detection a revised text in published article, the article will be withdrawn or the correction article will be published by the Author. Questions relating to the text or recycled avtoplagiarism are assessed taking into account the competence of the Author, age and scientific experience.

\section{Publication of the members of the editorial board}

Publication of the members of the editorial board is allowed. The review process of these manuscripts takes place without Authors participation. Member of the Editorial Board declares a conflict of interest with the publisher and the editorial board; a member of the editorial board is not involved in the process of peer-reviewing his own article. Communication with the editors on publication performs only through the executive secretary.

The review process is independent from the constitutors. All members of the Editorial Board have a written agreement with the constitutors. The constitutors have no right to influence the review process.

Commercial publications and advertisements are peer-reviewed equally as scientific publications with no benefits [3].

\section{Manuscripts retraction}

We retract manuscripts in case if:

- there any signs that the data has been fabricated or inappropriately manipulated;

- they were already published;

- plagiarism was found;

- the research was unethical;

- in case that the investigation of supposed malefaction associated with article were no fair or convincing evidences were not provided.

In case of Authors replacement and the reliability evidence provided, the manuscripts will not be retracted. Manuscript retraction process begins as soon as we find reasons for retraction, as usual accompanying the peer-review process. Published articles can be retracted too. Manuscript retraction process can be initiated by Author, Editorial Board or other journal.

\section{How we treat articles that are ready to be retracted}

If there is a possibility of correction, after the removal of all the queries, the article can be accepted for publication. Retracted articles, mostly contain severe disabilities.

If the article was published previously, in the next issue we publish a note referring to an earlier publication.
VSKM journal notify the journal where the article was published earlier.

"Cross articles». Articles containing previously published data, together with the original data with appropriate references do not retracts. The purpose of the retraction process is not to punish the Authors, but to provide reliable data [4].

\section{Conflict of interest}

Each Author must declare a conflict of interest. A conflict of interest occurs in circumstances where the primary professional interest becomes affected by secondary interest (financial benefits, career advancement, encouragement of colleagues, friends, relatives, countrymen, highlighting the role of his department, institution). Influence of secondary interest leads to moral and ethical conflicts in relation to patients, health professionals and the whole scientific community.

In medicine, the primary professional interests are related to quality of care, proper treatment of diseases, the well-being of patients, professionalism, impartiality and integrity of the research, as well as open and honest editorial work. The secondary interests are numerous, complex in its origin, and not always easily distinguishable, even for professionals. They can arise from a desire to benefit financially from professional activities to strengthen the position of some scientific statements to advance his/her career development, or for the benefit of family members, friends and colleagues from the same city, country or institution, etc.

A conflict of interest can be commercial (financial), the intellectual, academic (competitive), ideological, have a personal character or territorial characteristics.

Most often, there is a commercial conflict of interest in the publication of data in biomedical research. You must declare the sponsorship, grants and other types of material incentives.

In the absence of a conflict of interest must be declared no conflict of interest. When in doubt, the editorial board will always help. Declaring a conflict of interests helps readers to critically evaluate the article with the influence of secondary interests of the Author [5].

\section{LITERATURE}

1. Guidance for Editors: Research, Audit and Service Evaluations._URL: http://publicationethics.org/resources/ guidelines

2. URL: www.singaporestatement.org

3. A short guide to ethical editing for new editors.- URL: http://publicationethics.org/resources/guidelines

4. Retraction guidelines._URL: http://publicationethics.org/ resources/guidelines

5. Croat Med. J. 2013;54:600-8; doi: 10.3325/cmj.2013.54.600 Armen Yuri Gasparyan1, Lilit Ayvazyan2, Nurbek A. Akazhanov3, George D. Kitas1,4 a.gasparyan@gmail. com Conflicts of interest in biomedical publications: considerations for Authors, peer reviewers and editors. 


\section{ПРАВИЛА ОФОРМЛЕНИЯ СТАТЕЙ И ТЕЗИСОВ ДЛЯ АВТОРОВ В ЖУРНАЛ И ПРИЛОЖЕНИЯ “ВЕСТНИК СОВРЕМЕННОЙ КЛИНИЧЕСКОЙ МЕДИЦИНЫ" ISSN 2071-0240 (PRINT), ISSN 2079-553X (ONLINE)}

1. Статья должна быть набрана в текстовом редакторе Word 2003-2013, шрифт Times New Roman, 12 , межстрочный интервал 1,5, форматирование по ширине, без переносов, должна быть напечатана на одной стороне листа форматом А4. Поля: сверху 25 мм, снизу 20 мм, слева 30 мм, справа 15 мм. Стиль статей должен быть ясным и лаконичным.

2. В начале первой страницы статьи указывают (через пробел между ними):

1) () инициалы и фамилии всех авторов через запятую, год (например: () Н.Б. Амиров, А.А. Визель, М.А. Даминова, 2015);

2) код по УДК;

3) название статьи (ЗАГЛАВНЫМИ БУКВАМИ) должно отражать основное содержание работы и обязательно должно быть представлено на русском и английском языках.

4) имя, отчество и фамилию(и) автора(ов) полностью, после каждой фрамилии указать ученую степень, ученое звание, занимаемую должность, полное название кафедры (подразделения), учреждения, города, страны, где работает(ют) автор(ы), на русском языке и их перевод на английский язык, контактный телесон и е-mail;

5) реферат, структурированный и отражающий основное содержание статьи, на русском языке (не менее 100 и не более 250 слов) и перевод структурированного реферата на английский язык (не менее 100 и не более 250 слов).

Редакция оставляет за собой право исправлять присланные авторами на английском языке без согласования с авторами название статьи, реферат и ключевые слова при противоречии их правилам английского языка или неправильного употребления терминологии. Например: внебольничная пневмония. Неправильный перевод: out-of hospital pneumonia. Правильный перевод: community acquired pneumonia;

6) ключевые слова, отражающие смысловую часть статьи (не более 6), на русском языке и их перевод на английский язык.

3. Принимаются к опубликованию статьи на английском языке, при этом должны быть выполнены все требования как для русскоязычных статей, но с обратным переводом соответственно.

4. Статья должна сопровождаться официальным направлением от учреждения, в котором выполнена работа, иметь визу научного руководителя, направление должно быть скреплено печатью учреждения, направляющего работу в редакцию журнала. Если работа представляется от нескольких учреждений, необходимо сопроводительное письмо, подтверждающее направление статьи для публикации в журнале, от каждого из них (необязательно, если нет конфлликта интересов между учреждениями). В направлении можно указать, является ли статья диссертационной.

5. Все статьи направляются на рецензирование. Редакция оставляет за собой право сокращать и редактировать присланные статьи. Не допускается направление в редакцию работ, напечатанных в других изданиях или направленных для печати в другие издания.
6. В конце статьи должны быть подписи всех авторов с указанием ученой степени и звания, полностью указаны фамилия, имя, отчество, место работы и должности всех авторов, контактный адрес, номер телефона и адрес электронной почты одного из авторов.

7. Высылать статью в печатном и электронном виде на удобном для авторов носителе данных (CD-R, CD$\mathrm{RW}$ или фрлеш-накопитель) одновременно с квитанцией об оплате по адресу: 420043, Казань, ул. Вишневского, 57-83 для Н.Б. Амирова или 420012, Казань, ул. Бутлерова, 49, КГМУ, в редколлегию журнала ВСКМ для Н.Б. Амирова и по e-mail: vskmjournal@gmail.com. Файл называется по фамилии первого автора. Если у первого автора несколько статей, то им присваиваются номера после фамилии, например: Амиров Н.Б.-1, Амиров Н.Б.-2 и т.д. Приветствуется направление фото первого автора в формате jpeg.

8. Рубрикация журнала: Передовая статья. Оригинальные исследования (клинико-теоретические публикации). Обзоры. Клинические лекции. Краткие сообщения. Организация здравоохранения. Дискуссии. Съезды, конференции, симпозиумы. Из практического опыта. История медицины (юбилейные и исторические даты). Экспериментальные исследования - клинической медицине. Клинический случай и др.

9. Объем статей в рубрику «Оригинальные исследования» не должен превышать 15 страниц, число рисунков - не более 5-6; таблицы должны быть построены наглядно, иметь название над таблицей, их заголовки должны точно соответствовать содержанию графр (междустрочный интервал в таблицах - 1); таблицы не должны представлять собой отсканированное изображение; рисунки должны иметь номер и название под рисунком. Отсканированные фотографии должны иметь разрешение не ниже $300 \mathrm{dpi.}$ Текст: все части статьи (текст, таблицы, рисунки и т.п.) должны быть приведены полностью в соответствующем месте статьи. Все цифры, итоги, проценты в таблицах должны быть тщательно выверены автором и должны соответствовать цифрам в тексте. В тексте необходимо указать ссылки на таблицы и рисунки и их порядковые номера. Статья должна быть тщательно отредактирована и выверена автором. Статьи объемом до 6 страниц могут быть размещены в рубрике «Краткие сообщения». В рубрику «Из практического опыта» принимаются статьи, освещающие оригинальный опыт авторов в медицинской практике. Объем статьи должен составлять не более 10 страниц машинописного текста.

Объем обзорно-теоретических статей и статей в рубрику «Клинические лекции» заранее согласовываются с редакцией журнала.

Рисунки, таблицы, реферат и список литературы входят в общий объем статьи.

В структуру статей входят разделы: Введение (с указанием в конце целей исследования). Материал и методы. Результаты и их обсуждение. Выводы. Перечень цитируемой литературы.

10. Библиографические ссылки в тексте статьи надо давать в квадратных скобках с указанием номера 
согласно списку литературы: Например: ...согласно данным [11]...

В конце статьи приводится список литературы в соответствии с ГОСТ 7.1-2003 «Библиографическая запись. Библиографическое описание. Общие требования и правила составления» (для обзоров - не более 50 , для оригинальных статей - не более 20 источников), в котором цитируемые авторы перечисляются в алфавитном порядке (сначала на русском, затем на иностранных языках). После фрамилии автора(ов) указываются названия работ, место издания, издательство, год издания, номер тома и выпуска, страницы (от - до) и ГОСТ Р7.0.5-2008 «Система стандартов по информации, библиотечному и издательскому делу. Библиографическая ссылка. Общие требования и правила составления».

Для вхождения в базу данных Scopus необходимо подавать список цитируемой русскоязычной литературы в романской транскрипции и перевод на английский язык в квадратных скобках. Для этого можно воспользоваться сайтом: http://translit.ru. Bo избежание ошибок, а также для облегчения работы не стоит делать транслитерацию вручную. Представление в References только транслитерированного (без перевода) описания недопустимо, так как делает такое описание совершенно нечитаемым (поэтому, после транслитерированного названия необходимо поместить перевод названия статьи на английском языке в квадратных скобках). N.B.! Если в списке есть иностранные публикации, то они полностью повторяются в русскоязычном списке литературы. Зарубежные базы данных огромное внимание уделяют правильной индексации ссылок. Таким образом, после списка литературы на русском, необходимо поместить References по указанному примеру:

Borisov, A.G. Spaechnaya bolezn' bryushnoi polosti [Adhesive abdominal disease] / A.G. Borisov, A.A. Volodin, I.R. Mihaylov [i dr.] // Endoskopicheskaya hirurgiya [Endoscopic surgery]. - 2011. - T. 4, № 3. S.51-63.

Примечание. Допускается порядок списка литературы по мере цитирования.

\section{ОБРАЗЕЦ ОФОРМЛЕНИЯ СТАТЬИ \\ И СПИСКА ЛИТЕРАТУРЫ}

(ㄱ Н.Н. Крывкина, Э.Н. Ахмадеева, А.Я.Валиуллина, 2015

Пробел

УДК 616-053.3:616.329-089

Пробел

СРАВНИТЕЛЬНАЯ ХАРАКТЕРИСТИКА ЗДОРОВЬЯ ДЕТЕЙ МЛАДЕНЧЕСКОГО ВОЗРАСТА, РОДИВШИХСЯ НЕДОНОШЕННЫМИ, В ЗАВИСИМОСТИ ОТ МАССЫ ТЕЛА ПРИ РОЖДЕНИИ

Пробел

Наталья Николаевна Крывкина, аспирант кафедры госпитальной педиатрии ГБОУ ВПО «Башкирский государственный медицинский университет» Минздрава России, Уфра, Россия, тел. 8-917-34-555-28, e-mail: sunnatali@msn.com

Эльза Набиахметовна Ахмадеева, докт. мед. наук, профессор, зав. кафедрой госпитальной педиатрии ГБОУ ВПО «Башкирский государственный медицинский университет» Минздрава России, Уфа, Россия, тел. 8-903-312-37-57, e-mail: pediatr@ufanet.ru
Альфия Ягуфраровна Валиуллина, канд. мед. наук, ассистент кафедры госпитальной педиатрии ГБОУ ВПО «Башкирский государственный медицинский университет» Минздрава России, Уфа, Россия, тел. 8-937-322-60-78, e-mail: doctoralfiya@gmail.com

\section{Пробел}

Реферат. Цель исследования - охарактеризовать здоровье детей младенческого возраста, родившихся недоношенными. Материал и методы. Под наблюдением находилось 519 недоношенных детей, которых разделили на 3 группы: 1-я группа - дети с экстремально низкой массой тела при рождении (44 ребенка), 2-я группа - дети с очень низкой массой тела при рождении (142 младенца) и 3-я группа - дети с низкой массой тела при рождении (333 младенца). Результаты и их обсуждение. Выявлено, что исходы перенесенных заболеваний у недоношенных детей исследуемых групп к концу первого года жизни были разнообразными - от практически здоровых до детей с ограниченными возможностями. Заключение. Факторами риска, влияющими на тяжесть исходов, являются отягощенный акушерско-гинекологический анамнез матери в $100 \%$ случаев, сам фракт недоношенности и весовая категория преждевременно родившихся младенцев.

\section{Пробел}

Ключевые слова: новорожденные, дети с низкой и экстремально низкой массой тела, раннее развитие недоношенных

Пробел

THE COMPARATIVE CHARACTERISTICS OF HEALTH PREMATURE INFANTS DEPENDING ON THEIRS BIRTH WEIGHT

Пробел

Natalia N. Kryvkina, graduate student of Department of hospital pediatrics of SBEI HPE «Bashkir State Medical University» Russian Ministry of Health, Ufa, Russia, tel. 8-917-345-55-28, e-mail: sunnatali@msn.com

Elsa N. Akhmadeeva, M.D., Professor, Head of Department of hospital pediatrics of SBEI HPE «Bashkir State Medical University» Russian Ministry of Health, Ufa, Russia, tel. 8-903-312-37-57, e-mail: pediatr@ufanet.ru

Alfia Ya. Valiullina, Ph.D., assistant of Professor of Department of hospital pediatrics of SBEI HPE «Bashkir State Medical University» Russian Ministry of Health, Ufa, Russia, tel. 8-937-322-60-78, e-mail: doctoralfiya@ gmail.com

Пробел

Abstract. Aim. The purpose of our study was to characterize health of premature infants. Matherial and method. Under our observation were 519 children. We divided them into 3 groups. In the first group were 44 preterm birth with extremely low birth weight. In the second - 142 premature with very low birth weight. And in the last one - 333 children with low birth weight. Results. It was revealed that outcomes of perinatal pathologies during first year of life were variables. It occur such healthy children as invalid infants. Conclusion. Factors, which may cause severe pathology, were not only the fact of preterm born, but also the compromised obstetric-gynecologic history of mothers in $100 \%$ of cases.

Пробел

Key words: premature infants, extremely low birth weight, obstetric-gynecologic history.

Пробел 
Текст структурированной статьи

Пробел

\section{Литература}

1. Аржанова, О.Н. Этиопатогенез невынашивания беременности / О.Н. Аржанова, Н.Г. Кошелева // Журнал акушерства и женских болезней. - 2004. - T. LIII, № 1. - С.37-41.

2. Виноградова, И.В. Катамнестическое наблюдение за детьми с экстремально низкой массой тела при рождении / И.В. Виноградова, М.В. Краснов, Л.Г. Ногтева // Практическая медицина. - 2008. - № 31. C.67-69.

3. Antenatal Corticosteroids Prior to 24 WEEKS "Gestation and Neonatal Outcome of Extremely Low Birth Weight Infants» / S. Abbasi, C. Oxford, J. Gerdes [et al.] // Am. J. Perinatol. — 2009. - Vol. 32. - P.19-23.

4. Gagliardi, L. Bronchopulmanary dysplasia and brain white matter damage in preterm infants: a complex relationship / L. Gagliardi, R. Bellu, R. Zanini // Pediatr. Perinat. Epidemiol. - 2009. - Vol. 23, № 6. - P.90582.

\section{Пробел}

\section{References}

1. Arzhanova, O.N. Etiopatogenez nevynashivaniya beremennosti [Aetiopathogenesis of recurrent pregnancy loss] / O.N. Arzhanova, N.G. Kosheleva // Zhurnal akusherstva i zhenskih boleznei [Obstetrics and gynecopathy journal]. — 2004. - T. LIII, № 1. - S.37-41.

2. Vinogradova, I.V. Katamnesticheskoe nablyudenie za det'mi s ekstremal'no nizkoi massoi tela pri rozhdenii [Follow-up of children with extremally low birth weight] / I.V. Vinogradova, M.V. Krasnov, L.G. Nogteva // Prakticheskaya medicina [Practical medicine]. — 2008. № 31. - S.67-69.

3. Antenatal Corticosteroids Prior to 24 WEEKS "Gestation and Neonatal Outcome of Extremely Low Birth Weight Infants» / S. Abbasi, C. Oxford, J. Gerdes [et al.] // Am. J. Perinatol. — 2009. - Vol. 32. - P.19-23.

4. Gagliardi, L. Bronchopulmanary dysplasia and brain white matter damage in preterm infants: a complex relationship / L. Gagliardi, R. Bellu, R. Zanini // Pediatr. Perinat. Epidemiol. — 2009. — Vol. 23, № 6. — P.90—582.

11. Краткие сообщения и тезисы предоставляются объемом не более 1-4 страниц машинописного текста без иллюстраций, таблиц и списка литературы, структурированные как тезисы: название ЗАГЛАВНЫМИ БУКВАМИ. С новой строки - Ф.И.О. автора(ов) полностью. С новой строки учреждение, город, страна. С новой строки через интервал - цель исследования, материал и методы, результаты и их обсуждение, выводы (заключение). При оформлении кратких сообщений в сокращенном виде редакция оставляет за собой право опубликовать их в приложении к журналу. Перевод кратких сообщений и тезисов на английский язык увеличивает вероятность цитирования англоязычными авторами.

12. Сокращения слов, имен, названий (кроме общепринятых сокращений физических мер, химических и математических величин и терминов) не допускаются. Единицы измерений должны быть приведены в системе СИ.

13. При формировании материалов конференций и съездов в приложение к журналу принимаются тезисы. Правила оформления тезисов такие же, как для коротких сообщений.
14. Уважаемые коллеги! В связи с тем, что статьи и сведения в статьях, публикуемых в научно-практическом журнале «Вестник современной клинической медицины», будут помещаться в ведущих российских и мировых библиографических и реферативных изданиях, в электронных информационных системах, включая размещение их электронных копий в базе данных Научной электронной библиотеки (НЭБ), представленной в виде научного информационного ресурса сети Интернет www.elibrary.ru, а также включаться в одну из трех систем цитирования Web of Science: Science Citation Index Expanded (база по естественным наукам), Social Sciences Citation Index (база по социальным наукам), Arts and Humanites Citation Index (база по искусству и гуманитарным наукам), Scopus, Web of Knowledge, Astrophysics, PubMed, Mathematics, Chemical Abstracts, Springer, Agris, GeoRef, авторы оригинальных статей должны предоставлять на безвозмездной основе редакции журнала права на использование электронных версий статей, соблюдать международные правила построения публикаций и резюме к ним. Направление статей в журнал по умолчанию считается согласием авторов на безвозмездное использование электронных версий статей.

15. Статьи, офрормленные не в соответствии с указанными правилами, не рассматриваются редколлегией и не возвращаются.

16. В связи с тем, что журнал издается на средства авторов и подписчиков, стоимость публикации одной страницы формата A4 составляет 600 (шестьсот) рублей. Квитанция об оплате присылается вместе со статьей.

\section{Реквизиты для перевода:}

ООО «ММЦ «Современная клиническая медицина» ОГРН 1131690016677:

ИНН/КПП 1655265546 / 165501001

Р/счет 40702810500000002685

в ОАО АИКБ «Татфондбанк» г. Казань

БИК 049205815

Кор./счет 30101810100000000815 в ГРКЦ НБ РТ

17. С очных аспирантов (единственный автор) за публикацию рукописей плата не взимается.

18. Правила оформления статей могут совершенствоваться в соответствие с требованиями ВАК и Scopus. Следите за изменениями на сайтах журнала, а также в последнем вышедшем номере журнала.

По возникающим вопросам обращаться в редколлегию журнала: Амиров Наиль Багаувич (главный редактор), e-mail: namirov@mail.ru; Визель Александр Андреевич (зам. главного редактора), e-mail: lordara@ mail.ru; Даминова Мария Анатольевна (ученый секретарь журнала), e-mail: daminova-maria@yandex. ru; Шаймуратов Рустем Ильдарович (компьютерное сопровождение журнала), e-mail: russtem@gmail.com. Телефон редакции: +7 (843) 291-26-76, фракс +7 (843) 277-88-84, www.vskmjournal.org

По вопросу размещения рекламы в журнале и оформлению договоров обращаться в отдел договоров и рекламы ООО «ММЦ «Современная клиническая медицина». Контактное лицо, руководитель отдела Амирова Рената Наилевна, 420043, Казань, ул. Вишневского, 57-83, тел. 8-903-307-99-47; e-mail: renata1980@ mail.ru 


\section{THE BULLETIN OF CONTEMPORARY CLINICAL MEDICINE ISSN 2071-0240 (PRINT), ISSN 2079-553X (ON LINE) THE RULES FOR ARTICLES REGISTRATION FOR AUTHORS}

Подробная информация о журнале, а также полные версии публикаций размещаются в открытом доступе на сайтах: www.vskmjournal.org, www.kgmu.kcn.ru, www.cyberleninka.ru, https://twitter.com/vskmjournal

1. The article should be edited in Word, Times New Roman font size of 12 , interval of 1,5 , in width formatting, non carrying, interval in tables of 1 only on one side of the sheet. Printing fields should be 25 мм from top, $20 \mathrm{~mm}$ from the bottom, $30 \mathrm{~mm}$ from left, $15 \mathrm{~mm}$ from right. Pages should not be numbered. Article style should be laconic and clear.

2. Please, register on the first page of article according to the followings: (through the blank):

1) ( initials and surname of all authors, year (for example: (C) N.B. Amirov, A.A. Vizel, M.A. Daminova, 2015);

2) code of the UDC;

3) TITLE OF ARTICLE (IN CAPITAL LETTERS) in Russian and English;

4) names of authors (full); scientific degrees, position, full name of the department, institution, contact phone number and e-mail address (in Russian and English);

5) abstracts of the article in Russian (from 100 to 250 words) and English; $6)$.

6) key words in Russian and English (not more than

3. Article written in English is accepted for publishing (according to the same rules with the abstract and key words translated into Russian).

4. The article should be referred by official letter from Institution where the basic material for article was performed with stamp and signed by research director. If article referred from the few foundations letters of recommendation should be applied from each foundation. Please, mention if article reflects materials from thesis.

5. All articles are peer-reviewed. Editorial Committee keeps rights to reduce and edit articles (in coordination with authors). Articles already published or directed in (to) other Editions are not accepted.

6. Each author of the article should sign in the end of the article and mention his full name, position and scientific degree in foundation, corresponding address with telephone number and e-mail address of one of the authors.

7. 1 copies of the article should be mailed to the Editorial Committee with electronic copy (floppy 3,5" 1,44 MB, CD-R, CD-RW), e-mail: vskmjournal@gmail.com, namirov@mail.ru, lordara@mail.ru , hazova_elena@mail. ru, russtem@gmail.com. This copy should be named by first author. If the first author sends a few articles they will be consecutively numbered, for example: Amirov N.B.-1, Amirov N.B.-2, and so on. A photo of the first author in .jpg format is welcomed.
8. Rubrication of articles: Leading article. Original articles (clinical and theoretical papers). Surveys. Lections. Brief information. Reviews. Discussions. Conventions, symposiums, conferences, Meetings, Societies. Jubelee dates, History of Medicine. Clinical trials.

9. Volume of paper referring to «Original investigations» should not exceed 15 pages and numbers of pictures $5-6$, tables must be set presentable, clearly titled, according to the text (with interval of 1). All parts of the text should be placed on its own order. All figures and results, in tables must be thoroughly checked by authors and meet figures in text. All tables should be placed in the right order. Pictures and tables are included in article volume. In rubric «From practical experience» papers reflecting authors original experience in medical practice are accepted in volume of not more than 10 pages. Volume of the articles of "theoretical review» and "Clinical lections» suppose to be discussed with Editorial Committee beforehand.

Article content: introduction with aim and tasks of the investigation; material and methods; results; discussion;

conclusion (s); refereeing literature.

10. Bibliographic references in text should be given in numbers in square brackets according to the list of the literature. Example: according to the data [11] ... References list should be given in the end of the article (for Reviews not more than 50 sources, for Original papers not more than 20). Cited authors should be followed by alphabetical order (first in Russian, then in foreign languages (English). After author's names the title of the article, place of edition, editorial year, source volumes, numbers and pagers should be given. (following the ГОСТ 7.1-2003 «Bibliographic description of documents»).

Note: List of the literature according to citation could be allowed.

Words, names and titles abbreviation (except terms, rates and values widely used in physics, chemistry, mathematic) not allowed. Measuring units ought to be in the Système International (SI) units.

11. Abstracts of the conferences and congresses are accepted to the Supplement of the Journal. Rules for the abstracts are the same as for the Brief Information.

12. Articles made out of required rules wouldn't be considered and returned back to authors.

13. Publication for post-graduate students is free.

Phone +7(843)291-26-76; fax +7(843)277-88-84. www . vskmjournal.org, www.kgmu.kcn.ru, www.es.rae.ru/vskm, www.cyberleninka.ru, https://twitter.com/vskmjournal. Department of advertising: «Modern Clinical Medicine», 57-83, Vishnevsky str., Kazan-city, Republic of Tatarstan, Russia, 420043. Renata N. Amirova, tel. +7-903-307-9947; e-mail: renata1980@mail.ru 


\section{ПОРЯДОК РЕЦЕНЗИРОВАНИЯ РУКОПИСЕЙ, НАПРАВЛЯЕМЫХ НА ПУБЛИКАЦИЮ В НАУЧНО-ПРАКТИЧЕСКИЙ ЖУРНАЛ «ВЕСТНИК СОВРЕМЕННОЙ КЛИНИЧЕСКОЙ МЕДИЦИНЫ»}

1. Принимаются только рецензии от доктора наук - специалиста той области науки, которой посвящена статья и не являющегося руководителем или консультантом диссертационного исследования автора статьи. Подпись доктора наук должна быть заверена гербовой печатью организации, в которой работает рецензент. К статье могут прилагаться рецензии нескольких докторов наук.

2. Все статьи оцениваются рецензентами по следующим параметрам:

- оригинальность статьи;

- значимость статьи;

- качество статьи;

- способ представления материала;

- адекватность цитируемых источников;

- степень соответствия рубрикам журнала.

\section{ПРИМЕРНАЯ СТРУКТУРА РЕЦЕНЗИИ НА СТАТЬЮ}

В редакцию журнала «Вестник современной клинической медицины»

$$
\text { РЕЦЕНЗИЯ }
$$

на статью:<авторы, название> 20 _ г.

Статья посвящена решению актуальной задачи<...>

В ней рассматривается<...>; предлагается<...>

По статье можно сделать следующие замечания <...>

Статья содержит новые результаты, представляет интерес для специалистов в области<...>и может быть рекомендована к публикации в научном журнале «Вестник современной клинической медицины».

В случае отрицательного мнения рецензента о возможности публикации необходимо обоснование или рекомендации по доработке рукописи.

Должность, ученая степень, ученое звание

Подпись

Расшифровка подписи

Дата

О себе (рецензент) сообщаю:

Фамилия

Имя, отчество

Организация

Ученая степень

Звание, должность

E-mail

@

Служ.тел. (с кодом города)

Факс (с кодом города)

Почтовый адрес (с индексом)

моб. тел. или дом. тел.

Личная подпись рецензента:

\section{Уважаемые коллеги!}

Направляя рецензию на статью для научного журнала «Вестник современной клинической медицины», вы тем самым удостоверяете, что данная статья содержит новые интересные результаты и заслуживает публикации.

Редакция журнала благодарит вас за сотрудничество. 


\section{ВЕСТНИК СОВРЕМЕННОЙ КЛИНИЧЕСКОЙ МЕДИЦИНЫ}

Том 8, выпуск 3, 2015

Научно-практический журнал

В авторской редакции

Обложка художника С.Ф.Сафаровой

Техническая редакция Ю.Р.Валиахметовой

Верстка Т.Д.Торсуевой

Корректор Н.А.Петрова

Формат 60×841\% 8 . Подписано в печать 08.06.15. Усл.печ.л. 10,23. Тираж 3000 экз. Заказ 15-78

Цена договорная

Оригинал-макет изготовлен издательством «Медицина» ГАУ «РМБИЦ». 420059 Казань, ул. Хади Такташа, 125. Отпечатано отделом оперативной полиграфии ГАУ «РМБИЦ». 420059 Казань, ул. Хади Такташа, 125

\section{THE BULLETIN OF CONTEMPORARY CLINICAL MEDICINE}

\section{Volume 8, issue 3, 2015}

Scientific-practical journal

Edited by authors

Cover's designer - C.F. Safarova. Technical editing - Ju.R.Valiakhmetova. Page make-up - T.D.Torsueva. Proofreader - N.A.Petrova

Format $60 \times 84 \frac{1}{8}$. Signed for publication 08.06.15. Conventional printer's sheet 10,23.

Circulation -3000 copies. Order 15-78

Free price

Original make-up page is made by the publishing house «Medicina» of SAI «RMLIC» 420059 Kazan, Khady Taktash St., 125. Printed by the department of operative polygraphy of SAI «RMLIC». 420059 Kazan, Khady Taktash St., 125 


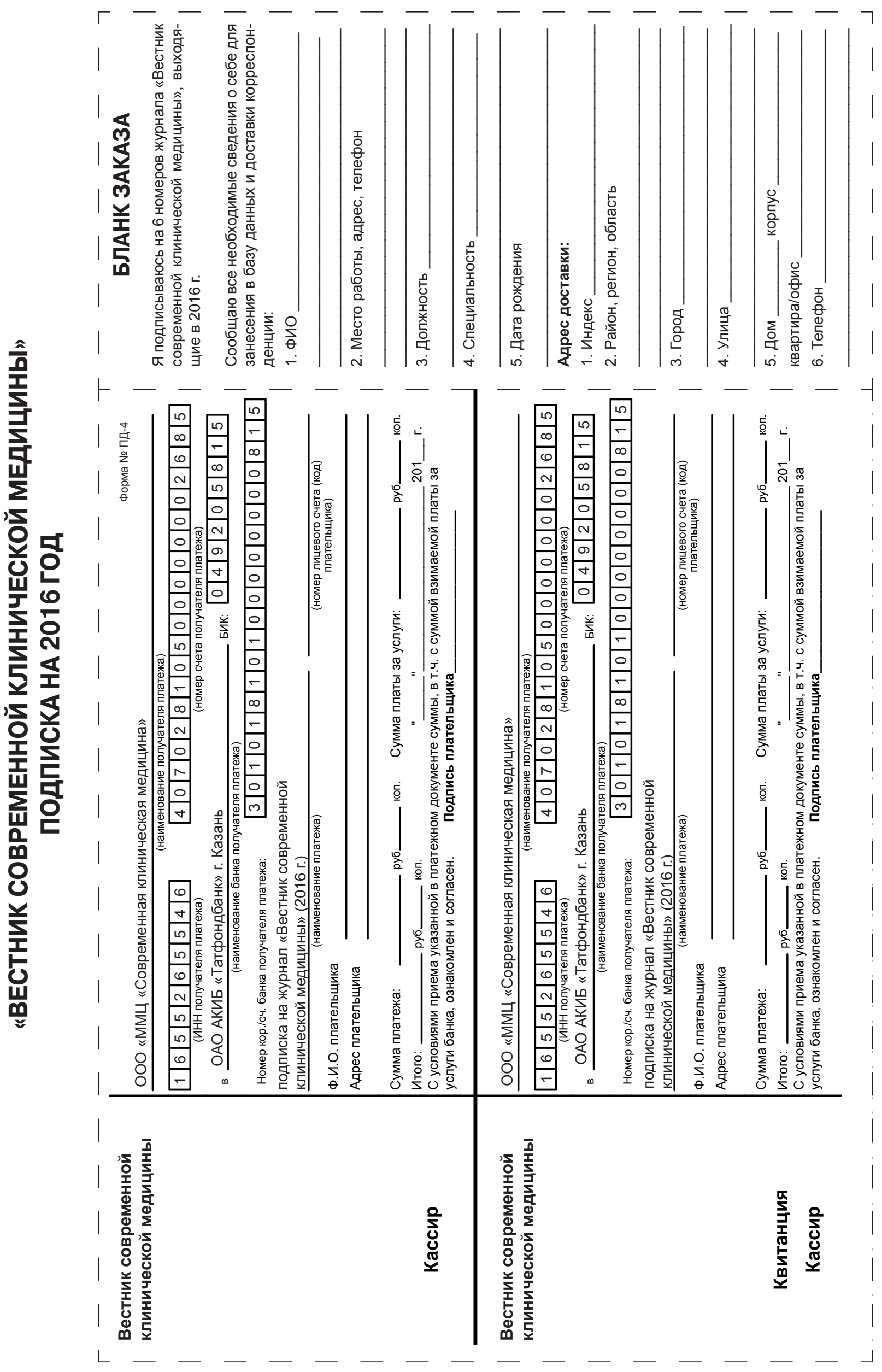

